\title{
$9 /, 3.92820$ \\ Two Long-Term Instrumental Climatic Data Bases of the People's Republic of China
}

Contributed by

Tao Shiyan, Fu Congbin, Zeng Zhaomei, Zhang Qingyun

Institute of Atmospheric Physics

Chinese Academy of Sciences

Beijing, China

Prepared by D. P. Kaiser

Carbon Dioxide Information Analysis Center

Oak Ridge National Laboratory

Oak Ridge, Tennessee, U.S.A.

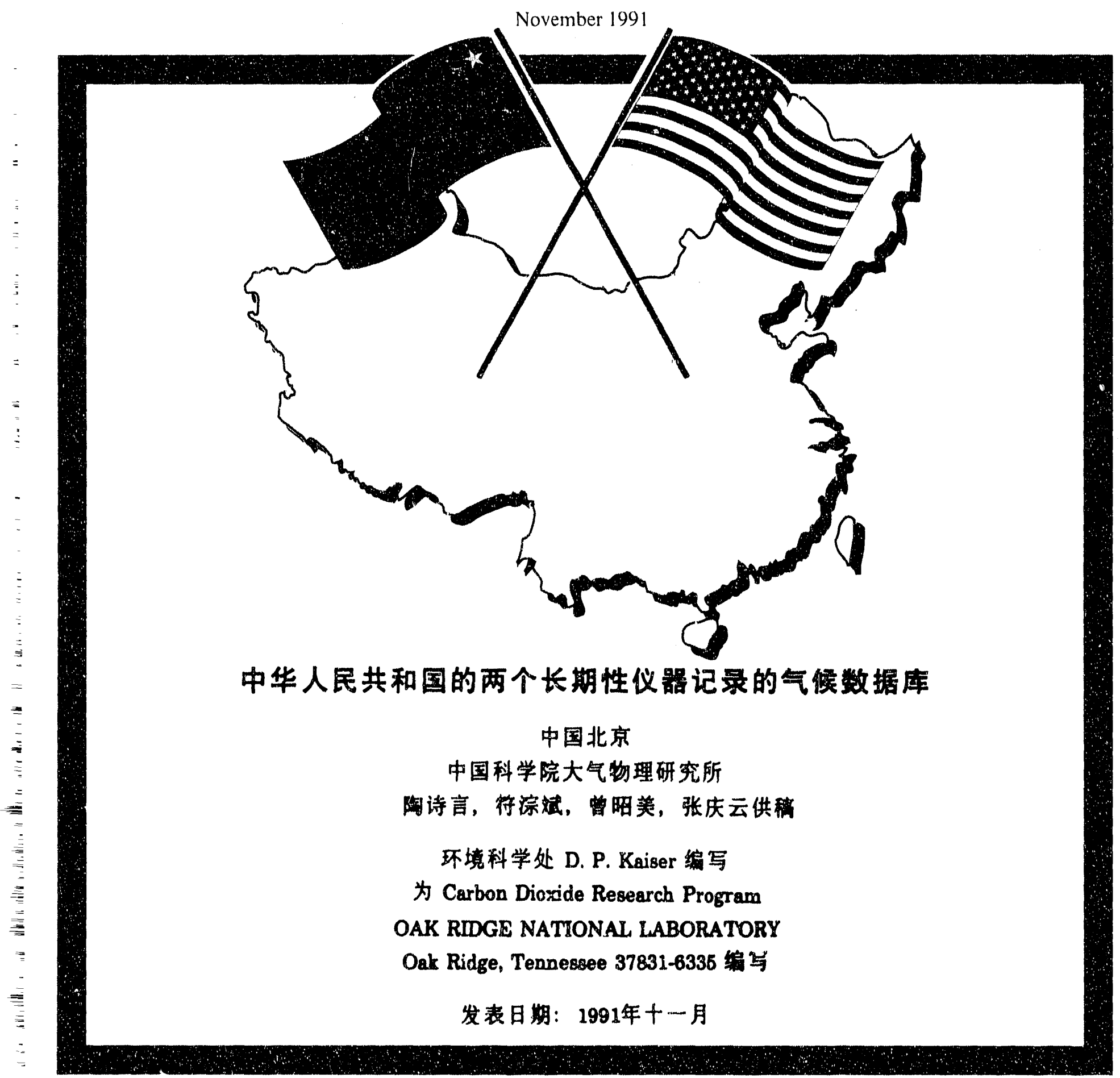


This report has been reproduced directly from the best available copy.

Available to DOE and DOE contractors from the Office of Scientifle and Techntcal information, P.O. 80x 62, Oak Ridge, TN 37831; prices avallable from (616) 576-8401, FTS 626-8401.

Available to the public from the Netional Technical Information Service, U.S. Department of Commerce, 6285 Port Royal Rd., Springtield, VA 22161.

This report was prepared as an account of work sponsored by an agency of the United States Government. Nelther the United States Government nor any agency thereof, nor any of their employses, makes any warranty, express or implied, of assurnes any legal liability or responsiblity for the accuracy, completeness, or usefuiness of any information, apparatus, product, or proceses disclosed, or represents that its use would not infringe privately owned rights. Reference herein to any specific commercial product, procese, or service by trade name, trademark, manufacturer, or othenwise, does not necessarly consthtute or Imply its endorsement, recommendation, or favoring by the United States Government or any agency thereof. The views and opinions of authors cxpressed herein do not necessarlly state or reflect those of the United Siates Government or any agency thereof. 


\author{
Environmental Sciences Division
}

\title{
TWO LONG-TERM INSTRUMENTAL CLIMATIC DATA BASES OF THE PEOPLE'S REPUBLIC OF CHINA
}

\author{
Contributed by \\ Tao Shiyan, Fu Congbin, Zeng Zhaomei, Zhang Qingyun \\ Institute of Atmospheric Physics \\ Chinese Academy of Sciences \\ Beijing, China \\ Prepared by D. P. Kaiser \\ Environmental Sciences Division \\ Publication No. 3747 \\ Date Published: November 1991 \\ Prepared for the \\ Carbon Dioxide Research Program \\ Environmental Sciences Division \\ Office of Health and Environmental Research \\ U.S. Department of Energy \\ Budget Activity Number KP 0500000 \\ Prepared by the \\ Carbon Dioxide Information Analysis Center \\ OAK RIDGE NATIONAL LABORATORY \\ Oak Ridge, Tennessee 37831-6335 \\ managed by \\ MARTIN MARIETTA ENERGY SYSTEMS, INC. \\ for the \\ U.S. DEPARTMENT OF ENERGY \\ under contract DE-AC05-84OR21400
}




\title{
环境科学处
}

\section{中华人民共和国的两个长期性仪器记录的气候数据库}

\author{
中国北京
}

中国科学院大气物理研究所

故诗言, 符淙斌, 曾昭美, 张庆云供稿

\author{
环境科学处 D. P. Kaiser 编写 \\ 文件编号 3747
}

发表日期：1991年十一月

发表日期：1991年十二月

发表日期：1992年一月

发表日期：1992年二月

为 Carbon Dioxide Research Program

Environmental Sciences Division

Office of Health and Environmental Research

U.S. Department of Energy 编写

(Budget Activity Number KP 050000 0)

OAK RIDGE NATIONAL LABORATORY

Oak Ridge, Tennessee 37831-6335 编写

MARTIN MARIETTA ENERGY SYSTEMS, INC. 为

美国能源部管理

(契约DE-AC05-84OR21400) 
TABLE OF CONTENTS

Page

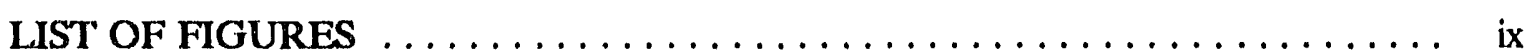

LIST OF TABLES $\ldots \ldots \ldots \ldots \ldots \ldots \ldots \ldots \ldots \ldots \ldots \ldots \ldots \ldots \ldots \ldots \ldots$

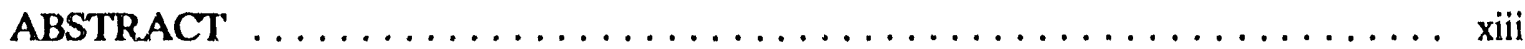

PART 1: INFORMATION ABOUT THE DATA PACKAGE $\ldots \ldots \ldots \ldots \ldots, 1$

1. NAME OF THE NUMERIC DATA PACKAGE $\ldots \ldots \ldots \ldots \ldots \ldots \ldots, 3$

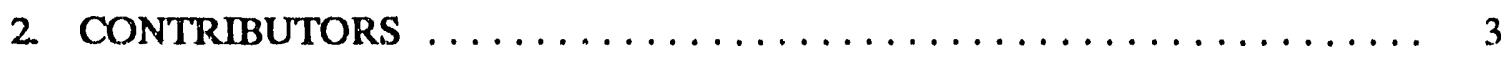

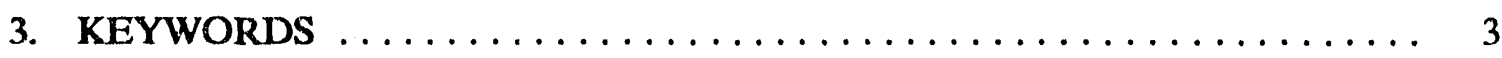

4. BACKGROUND INFORMATION $\ldots \ldots \ldots \ldots \ldots \ldots \ldots \ldots \ldots \ldots \ldots \ldots \ldots$

5. SOURCE AND SCOPE OF THE DATA $\ldots \ldots \ldots \ldots \ldots \ldots \ldots \ldots$

6. APPLICATIONS OF THE DATA $\ldots \ldots \ldots \ldots \ldots \ldots \ldots \ldots \ldots \ldots \ldots \ldots$

7. LIMITATIONS AND RESTRICTIONS $\ldots \ldots \ldots \ldots \ldots \ldots \ldots \ldots \ldots, 41$

8. QUALITY ASSURANCE OF THE PRC CLIMATE DATA BASES ...... 42

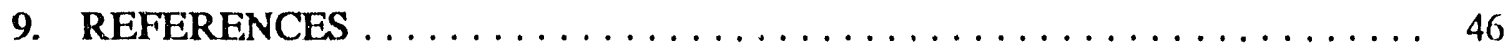

10. HOW TO OBTAIN THE DATA PACKAGE $\ldots \ldots \ldots \ldots \ldots \ldots \ldots \ldots$

PART 2: INFORMATION ABOUT THE MAGNETIC TAPE $\ldots \ldots \ldots \ldots \ldots 49$

11. CONTENTS OF THE MAGNETIC TAPE $\ldots \ldots \ldots \ldots \ldots \ldots \ldots \ldots, 51$

12. DESCRIPTIVE FILE ON THE MAGNETIC TAPE $\ldots \ldots \ldots \ldots \ldots \ldots . \ldots 3$

13. LISTINGS OF THE FORTRAN IV DATA RETRIEVAL PROGRAMS . . . . 67

14. LISTINGS OF THE SAS INPUT/OUTPUT RETRIEVAL PROGRAMS $\ldots 72$

-SAS is a registered trademark of SAS Institute, Inc., Cary, North Carolina 27511-80(0). 
15. VERIFICATION OF DATA TRANSPORT

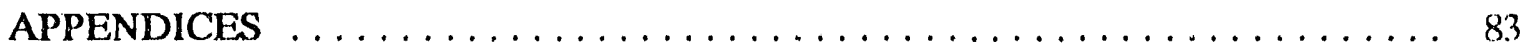

APPENDIX A: INSTRUMENTATION AND DATA COLLECTION

METHODS OF STATIONS IN THE PRC

60-STATION CLIMATE NETWORK . . . . . . . . . . A A-1

APPENDIX B: STATION HISTORIES OF THE PRC 60-STATION

CLIMATE NETWORK . . . . . . . . . . . . . . . . . B B-1

APPENDIX C: SOURCES OF DATA FOR THE PRC 60-STATION

CLIMATE DATA SET $\ldots \ldots \ldots \ldots \ldots \ldots \ldots \ldots \ldots \ldots \ldots$

APPENDIX D: REPRINTS OF PERTINENT LITERATURE . . . . . . . . D D-1

Urban Heat Islands in China. by W.-C. Wang, Z. M. Zeng, and T. R. Karl. 1990. D.3 


\section{目录}

附图一览

附表一览

xi

提要

xv

第一编：关于数据包的资料

1 数字数据包的名称 3

2. 供稿者

3. 关键词

4. 背景资料

5. 数据的来源和范围

6. 数据的应用

7. 局限与限制

8. 中华人民共和国气候数据库的质量保证

9. 参考文献

10. 如何取得这个数据包

第二编：关于磁带的资料

11. 磁带记录的内容

12. 关于磁带的描述性文件

13. Fortran IV 数据检索程序一览表

14. $\mathrm{SAS}^{\mathrm{TM}}$ 输人与输出检索程序一览表

15. 数据传输的核查

附录:

附录一：中华人民共和国60台气候网络中各台的仪器设备与搜集数据的方法

附录二：中华人民共和国60台气候网络中各台的历史

附录三: 中华人民共和国 60 台气候数据集的数据来源

附录四: 有关文献的抽印本

Urban Heat Islands in China (中国的城市热岛) W.-C Wang, Zhaomei Zeng, and T. R. Karl. 1990. 


\section{LIST OF FIGURES}

Figure

Page

1. Percentage (a) and cumulative percentage (b) of stations from the PRC 60-station climate network with given record lengths

2. Number of stations in the PRC 60-station climate network with data for each year over the period 1841-1988

3. Distribution of stations from the PRC 60-station climate data

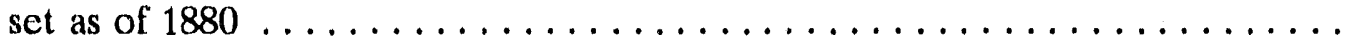

4. Distribution of stations from the PRC 60-station climate data set as of 1900 .

5. Distribution of stations from the PRC 60 -station climate data

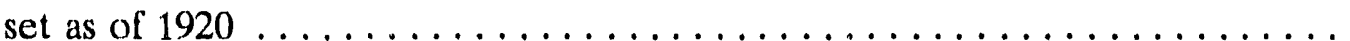

6. Distribution of stations from the PRC 60-station climate data

7. Distribution of stations from the PRC 60-station climate data set over the period 1951-1988

8. Distribution of stations from the PRC 60 -station climate data set which have data for 1945

9. Percentage (a) and cumulative percentage (b) of stations from the PRC 205-station temperature data set with given record lengths

10. Percentage (a) and cumulative percentage (b) of stations from the PRC 205-station precipitation data set with given record lengths

11. Number of stations in the PRC 205-station climate network with data for each year over the period 1880-1988

12. Distribution of stations from the PRC 205-station precipitation data set as of 1900

13. Distribution of stations from the PRC 205-station temperature data set as of 1920

14. Distribution of stations from the PRC 205-station precipitation data set as of 1920 
15. Distribution of stations from the PRC 205-station temperature data set as of 1940

16. Distribution of stations from the PRC 205-station precipitation data set as of 1940

17. Distribution of stations from the PRC 205.station temperature and precipitation data sets as of 1961

18. Distribution of stations from the PRC 205-station temperature data set which have data for 1945

19. Distribution of stations from the PRC 205-station precipitation data set which have data for 1945 


\section{LIST OF TABLES}

Table

Page

1. Instrumerital and proxy data sets compiled to date under the DOE/PRC collaborative research program $\ldots \ldots \ldots \ldots \ldots \ldots \ldots$

2. Sample listing of the PRC 60 -station climate data set $\ldots \ldots \ldots \ldots \ldots \ldots$

3. Inventory of stations in the PRC 60 -station climate network $\ldots \ldots \ldots \ldots \ldots$

4. Gaps in the periods of record of stations in the PRC

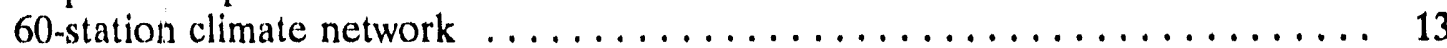

5. Sample listing of the PRC 205-station monthly mean

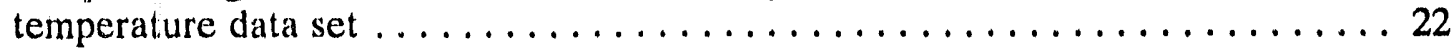

6. Sample listing of the PRC 205-station monthly total

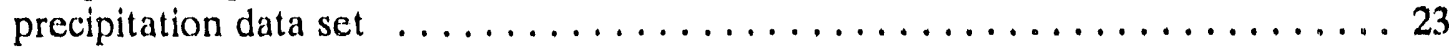

7. Inventory of stations in the PRC 205-station temperature

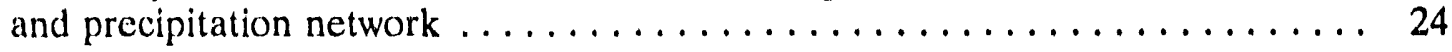

8. Characteristics of numeric variables from the 60-station

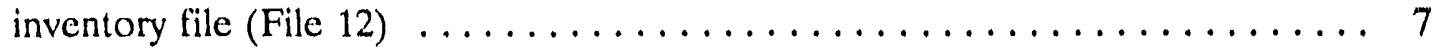

9. Characteristics of numeric variables from the 205 station inventory file (File 13)

10. Characteristics of numeric variables from the 60 -station

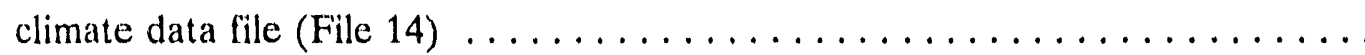

11. Characteristics of numeric variables from the 205 station monthly mean temperature file (File 15)

12. Characteristics of numeric variables from the 205 station monthly total precipitation file (File 16) 


\begin{abstract}
TAO SHIYAN, FU CONGBIN, ZENG ZHAOMEI, and ZHANG QINGYUN. 1991. Two long-term instrumental climatic data bases of the People's Republic of China. ORNL/CDIAC-47, NDP-039. Carbon Dioxide Information Analysis Center, Oak Ridge National Laboratory, Oak Ridge, Tennessee. 198 pp.
\end{abstract}

Two long-term instrumental data bases containing meteorological observations from the People's Republic of China (PRC) are described. These data sets were compiled in accordance with a joint research agreement signed by the United States Department of Energy (DOE) and the PRC Chinese Academy of Sciences (CAS) on August 19, 1987. CAS has provided records from 265 stations, partitioned into networks of 60 and 205 stations which each provide goorl geographical coverage of the PRC. The 60-station network data contain monthly neasurements of barometric pressure, air temperature, precipitation amount, relative humidity, sunshine duation, cloud amount, wind direction and speed, and number of days with snow cover. Detailed station histories are presented for all 60 stations. The 205 -station network data contain monthly mean temperatures and monthly precipitation totals; however, station histories are not currently available. Sixteen stations from these data sets (13 from the 60-station, 3 from the 205-station) have temperature and/or precipitation records which begin prior to 1900 , whereas the remaining stations began observing in the early to mid 1900s. Records from 262 stations extend through 1988; the remaining three station records extend through the early 1980s.

These data can be used in defining regional climate changes, establishing relationships between regional and large-scale climates, and in studying the climatic impacts of urbanization and increased concentrations of greenhouse gases. Additional uses could include examining impacts of periodic events such as volcanic eruptions or the El Niño/Southern Oscillation (ENSO). These data sets represent the most comprehensive, long-term instrumental Chinese climate data presently available. 


\section{提要}

喽诗言，符淙斌，曾明美，张庆云、1991。

Two Long-Term Instrumental Climatic Data Bases of the People's Republic of China (中华人民共和国的两个长期性仪器记录的气候数 据库). Carbon Dioxide Information Analysis Center, Oak Ridge National Laboratory, Oak Ridge, Tennessee. 198pp.

本文描述的内容为中华人民共和国气象观测资料的两个长期性仪器记录 的气候数据库。这些数据集是按照美国能源部 (DOE) 与中华人民共和国中国科 学院 (CAS) 于 1987年八月十九日签署的联合研究协定而编辑的。中国科学院提 供了 265 个气象台的观测记录。265个气象台分为两个网络; 其一有 60 台, 其二 有205台。每一网络均能在地理上很好地涵盖中国。来自60台网络的数据, 包括 气压、气温、降雨量、相对湿度、日光量和云量, 风向与风速, 积雪天数等参 数的每月平均值、极端值或总值。205台网络的数据, 包括每月平均温度和每月 总降雨量，其各台台史目前暂缺。这些数据集里的 16 个气象台（60台网络中的 13台和205台网络中的3台），拥有 1900年以前即已开始的温度与（或）降雨量 记录, 而其余各台, 却是在 1900 年代的初叶至中叶才开始观测工作的。所有 265 台的观测记录, 均截至 1988年为止。

这些数据可用来确定地区气候的改变、确定地区气候与大范围气候之间 的关系，并可用来研究气候对都市化和温室气体浓度增加的影响。另外的一些 用途，可包括确定火山爆发或厄尼诺和南方涛动(ENSO)等周期性事件的影响。 这些数据集能提供目前可供使用的最全面的长期性仪器记录的中国气候数据。 
PART 1

INFORMATION ABOUT THE DATA PACKAGE 


\section{NAME OF THE NUMERIC DATA PACKAGE}

Two Long-Term Instrumental Climatic Data Bases of the People's Republic of China

\section{CONTRIBUTORS}

Tao Shiyan, Fu Congbin, Zeng Zhaomei, and Zhang Qingyun

Institute of Atmospheric Physics

Chinese Academy of Sciences

Beijing, China

\section{KEYWORDS}

Regional climate change; temperature; precipitation; relative humidity; sunshine duration; cloud amount; snow cover; dominant wind direction/frequency; wind speed.

\section{BACKGROUND INFORMATION}

The U.S. Department of Energy (DOE) and the People's Republic of China (PRC) Chinese Academy of Sciences (CAS) signed an agreement on August 19, 1987, to carry out a joint research program on possible $\mathrm{CO}_{2}$-induced climate changes. Concern over such climate changes stems from rising atmospheric concentrations of $\mathrm{CO}_{2}$ and other greenhouse gases, as well as the ever-increasing global $\mathrm{CO}_{2}$ emissions from fossil fuel use (Marland and Rotty 1984). The nature of these phenomena signals the need for international research efforts in the area of possible man-made climate change. The intent of the DOE/CAS research agreement is to contribute to research efforts through the performance of four tasks: (1) analysis of general circulation models (GCMs), (2) preparation and analysis of proxy and instrumental data, (3) study of the relationship between large and regional-scale climates, and (4) study of possible increases in atmospheric $\mathrm{CH}_{4}$ (Koomanoff et al. 1988). Descriptions of these tasks and additional background information on each country's involvement in atmospheric $\mathrm{CO}_{2}$ research may also be found in Koomanoff et al. (1988).

This package contains and describes two long-term PRC instrumental climate data bases, which were exchanged along with PRC proxy data sets and U.S. instrumental data sets according to the data exchange protocol contained in the DOE/CAS agreement. A descriptive list of the instrumental and proxy data sets compiled to date under the agreement is contained in Table 1. This is essentially Table 1 from Koomanoff et al. (1988), containing many updates of data base specifics which have been derived from DOE analyses of these data sets performed since 1988. These data as a whole should be useful in defining regional climate changes, cstablishing relationships between regional and large-scale climates, and examining feedback processes during regional climate changes of selected case studies, such as wet and dry periods and desertification (Koomanoff et al. 1983). 


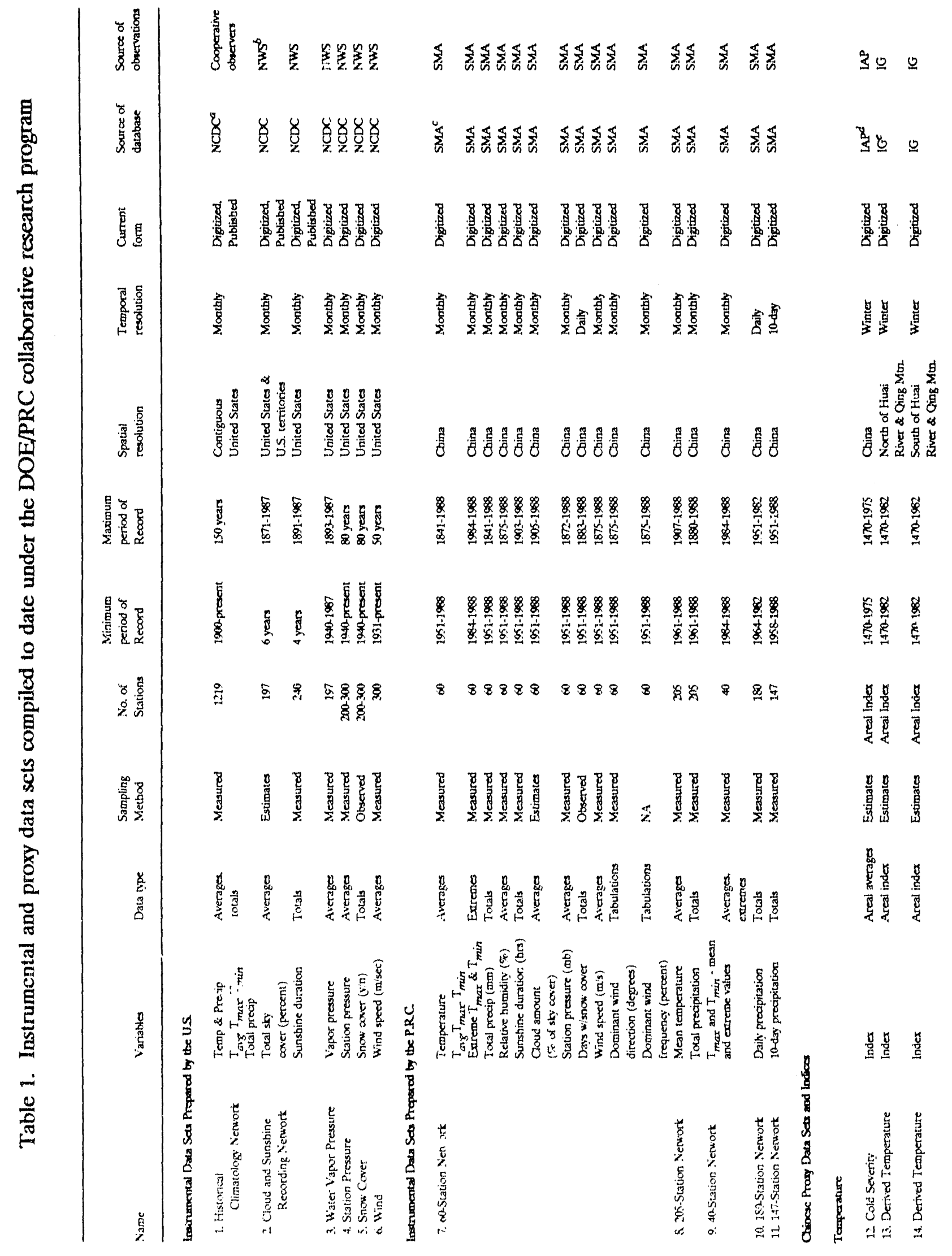




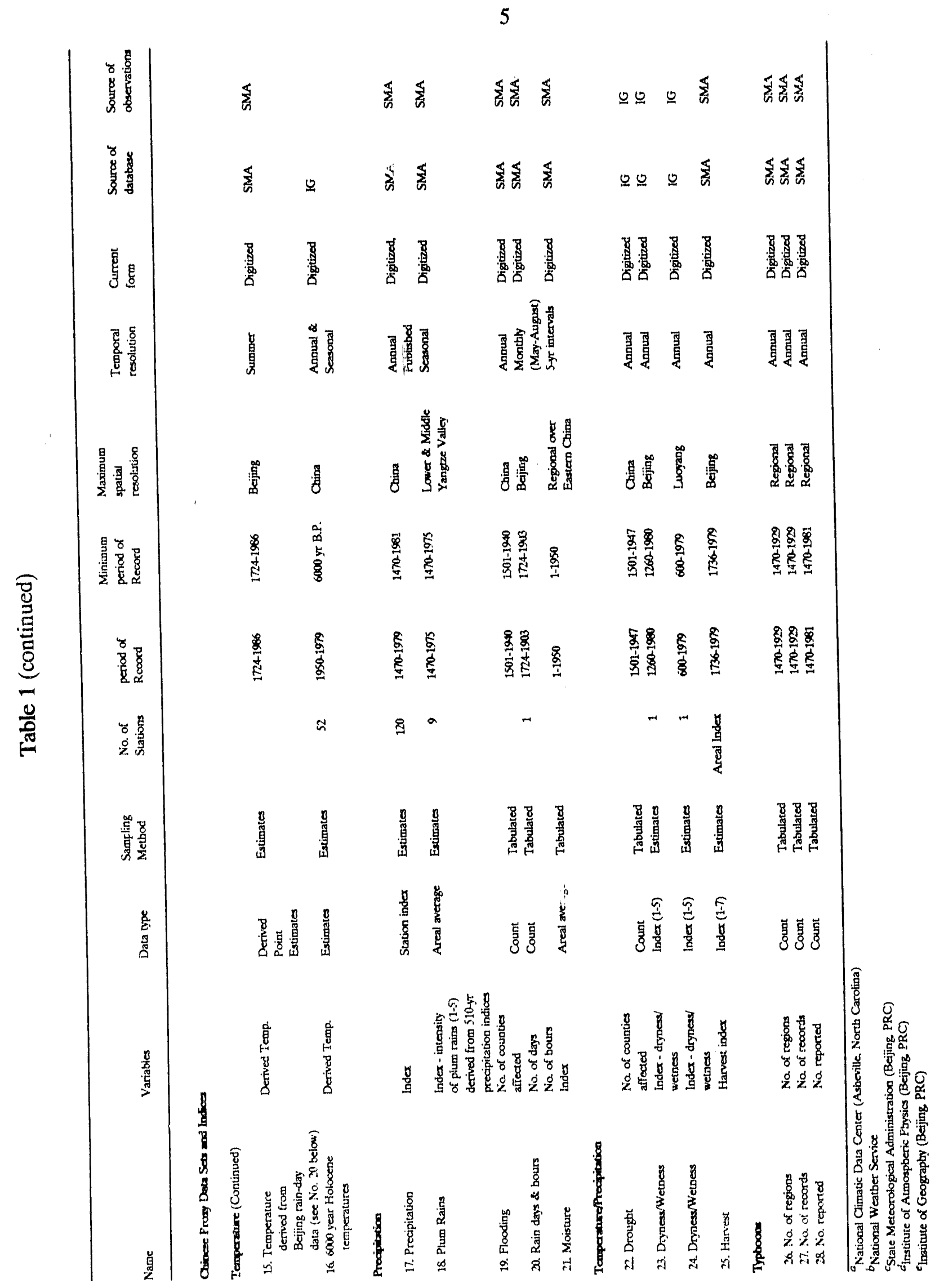


The PRC data sets contained in this package are comprised of observations from a 60-station network (Table 1, No. 7) and a 205-station network (Table 1, No. 8). These data sets contain monthly means, extremes, and totals of several important climatic variables. A subset of the monthly mean temperature data has already been used in assessing urban heat island effects in eastern China over the period 1954-1983 (Iones et al. 1990; Wang et al. 1990). The other types of data contained within will likely prove to be of similar practical value.

These data sets contain the most comprehensive, long-term instrumental Chinese climate data presently available. They may be used for comparison with the Chinese climate records published in the World Monthly Surface Station Climatology (Spangler and Jenne 1990), World Weather Records", and records published by Jones et al. (1985), Bradley et al. (1985), and Eischeid et al. (1991). The spatial and temporal coverage offered by these 265 stations significantly improves upon that of other published sources.

\section{SOURCE AND SCOPE OF THE DATA}

Two PRC climate data bases, derived mainly from instrument measurements, are presented in this package; one consists of monthly means, extremes, or totals of 14 meteorological variables observed at 60 stations, the other contains monthly mean temperatures and monthly precipitation totals from 205 stations. The two data bases have no stations in common. Each is described in detail in the following sections.

\section{0-STATION NETWORK}

As previously noted, the data from the 60-station network consist of monthly means, extremes, or totals of the following 14 meteorological variables:

- Mean Station Pressure (mb)

- Mean Temperature $\left({ }^{\circ} \mathrm{C}\right)$

- Mean Maximum Temperature $\left({ }^{\circ} \mathrm{C}\right)$

- Mean Minimum Temperature $\left({ }^{\circ} \mathrm{C}\right)$

- Total Precipitation (mm)

- Sunshine Duration (hours)

- Mean Cloud Amount (percentage of sky cover)

- Mean Relative Humidity (percent)

- Snow Days (days with snow cover)

- Dominant Wind Direction (degrees)

- Mean Wind Speed $(\mathrm{m} / \mathrm{s})$

- Dominant Wind Frequency (percent)

- Extreme Maximum Temperature $\left({ }^{\circ} \mathrm{C}\right)$

- Extreme Minimum Temperature $\left({ }^{\circ} \mathrm{C}\right)$

"ISmithsonian Institution (1927, 1934, 1947); U.S. Weather Burcau (1959,1967); National Iinvironmental Satellite, Data, and Information Service (1981-1983)] 
A sample listing of these data, illustrating the initial records contained in the 6()-station data file included with this package, is presented in Table 2. Each record contains one month's data; the World Meteorological Organization (WMO) station number, year, and month, followed by the data variables in the same order as previously listed. Each data value is given in tenths of its specified unit of measure. Missing data values are indicated by "-.9999".

Four basic criteria were used in selecting stations to make up the 60)-station network: (1) the station should be representative of a particular climate region of China, (2) the station's data should be of relatively high quality, (3) the period of record of the station should be reasonably long, and (4) the resulting station network should have a relatively uniform spatial distribution. An inventory of the selected stations is given in Table 3 . Thirteen stations began observing before 1900; Beijing's record being the longest, with temperature and precipitation data dating back to 1841. All 60 stations have temperature and/or precipitation data available from the beginning of their periods of record, with other types of observations beginning more randomly with time throughout the network. Records from all stations run through 1988, but extreme maximum and minimum temperature data are available for each station only since 1984.

A better feel for the relative length of station records in this data set can be gained using Fig. 1, which shows the percentage and cumulative percentage of stations falling into specific ranges of record length. In the figure the length of station record refers to the number of years for which the station has at least partial data, which in most cases is less than the number of years since the station opened (Discontinuities in the records are the norm). Figure 1 indicates nearly one-half of the 60 stations have some type of data for at least 70 years, but only $10 \%$ have data for 100 years or more. Figure 2 shows the number of stations with data for each year over the period 1841-1988. The most notable feature of this graph is the reduction in the number of stations operating in the 1940s (centered on 1945 and assumably related to World War II and its aftermath). Figure 2 also shows that data are available from all 60 stations over the period 1951-1988. Periods of whole years with no data have been omitted from the data set and are detailed in Table 4.

Maps depicting the evolution of the 60-station network are shown in Figs. 3-7. Threy indicate the locations of stations which had been opened as of 1880, 1900, 1920, 1940, and 1951, respectively. However, each station shown does not necessarily have data for that particular year. Numbers plotted at station locations correspond to the station identification numbers at the left of Tables 3 and 4. Stations with data for 1945 (the leanest data year in the era of decreased coverage caused by World War II) are mapped in Fig. 8.

Details of data collection methods used at the 60 stations (e.g., type, orientation, and calibration of instruments; daily observing times; and observational techniques) have been made available by CAS and are contained in Appendix A. Station histories extending through 1983 are available for all 60 stations and are given in Appendix B, Some 161 official PRC sources were used in compiling the data set and are listed in Appendix C. 


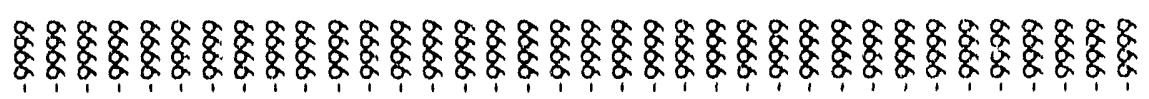
\%

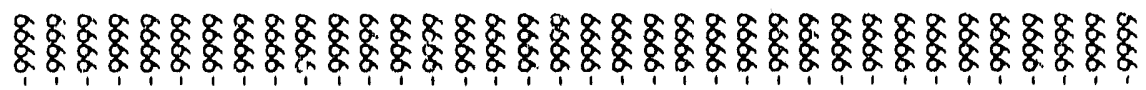

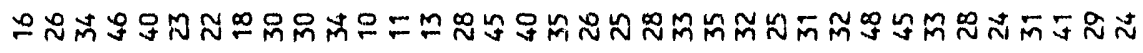

\%

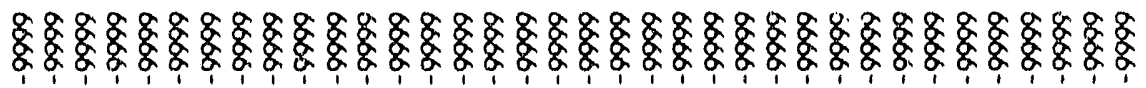

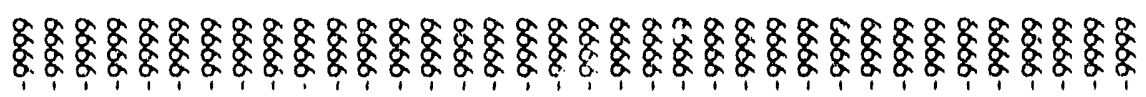

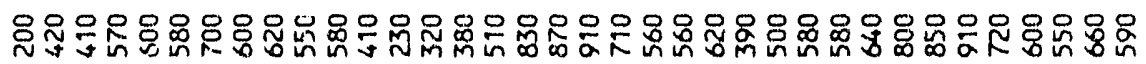

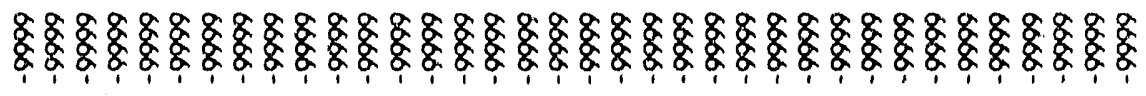

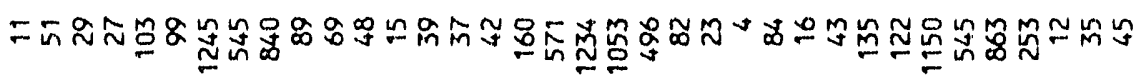

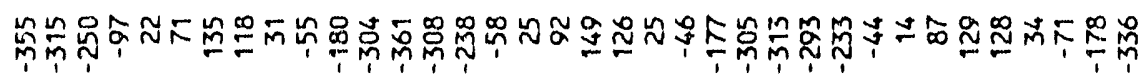

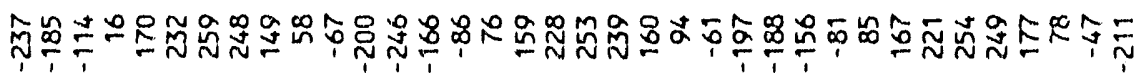

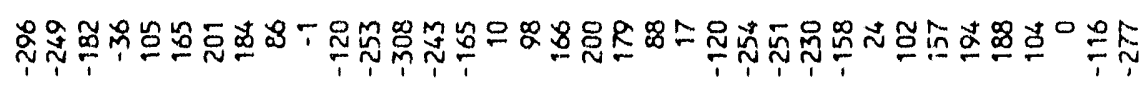

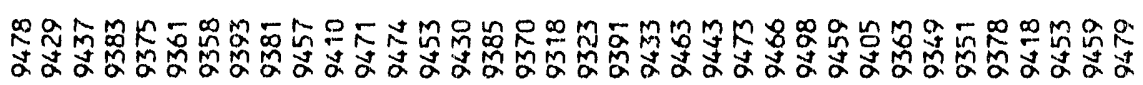

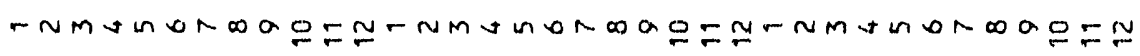

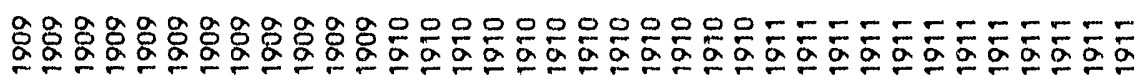

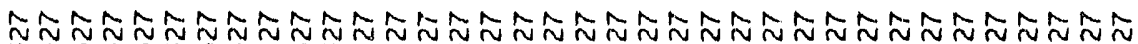

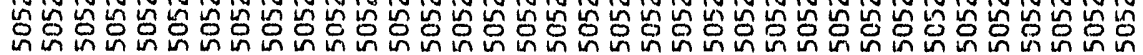


Table 3. Inventory of stations in the PRC 60-station climate network

\begin{tabular}{|c|c|c|c|c|c|c|}
\hline & Station name & $\begin{array}{l}\text { Station } \\
\text { number }\end{array}$ & Latitude & Longitude & Elcvation $(\mathrm{m})$ & $\begin{array}{l}\text { Beginning of } \\
\text { period of } \\
\text { record" }\end{array}$ \\
\hline 1 & Hailaer & 50527 & $49^{\circ} 13^{\prime}$ & $119^{\circ} 45^{\prime}$ & 612.8 & 1909 \\
\hline 2 & NenJiang & 50557 & $49^{\circ} 10^{\prime}$ & $125^{\circ} 14^{\prime}$ & 242.2 & 1939 \\
\hline 3 & BoKeTu & 50632 & $48^{\circ} 46^{\prime}$ & $121^{\circ} 55^{\prime}$ & 739.4 & 1914 \\
\hline 4 & QiQiHaEr & 50745 & $47^{\circ} 23^{\prime}$ & $123^{\circ} 55^{\prime}$ & 145.9 & 1930 \\
\hline 5 & HaErBin & 50953 & $45^{\circ} 41^{\prime}$ & $126^{\circ} 37^{\prime}$ & 171.7 & 1898 \\
\hline 6 & Yi Ning & 51431 & $43^{\circ} 57^{\prime}$ & $81^{\circ} 20^{\prime}$ & 662.5 & 1951 \\
\hline 7 & WuLuMuQi & 51463 & $43^{\circ} 47^{\prime}$ & $87^{\circ} 37^{\prime}$ & 917.9 & 1907 \\
\hline 8 & $\mathrm{HaMi}$ & .52203 & $42^{\circ} 49^{\prime}$ & $93^{\circ} 31^{\prime}$ & 737.9 & 1951 \\
\hline 9 & Jiu Quan & 52533 & $39^{\circ} 46^{\prime}$ & $98^{\circ} 31^{\prime}$ & 1477.2 & 1934 \\
\hline 10 & ZhangYe & 52652 & $38^{\circ} 56^{\prime}$ & $100^{\circ} 35^{\prime}$ & 1483.0 & 1937 \\
\hline 11 & XiNing & 52866 & $36^{\circ} 37^{\prime}$ & $10^{\circ} 41^{\circ}$ & 2261.2 & 1936 \\
\hline 12 & LanZhou & 52889 & $36^{\circ} 03^{\prime}$ & $103^{\circ} 53^{\prime}$ & 1517.2 & 1932 \\
\hline 1.3 & HuHeHaot'e & 53463 & $40^{\circ} 48^{\prime}$ & $111^{\circ} 38^{\prime}$ & 1063.0 & 1915 \\
\hline 14 & YinChuan & 53614 & $38^{\circ} 29^{\prime}$ & $106^{\circ} 13^{\prime}$ & 1111.5 & 1935 \\
\hline 15 & YuLin & 53646 & $38^{\circ} 14^{\prime}$ & $109^{\circ} 42^{\prime}$ & 1057.5 & 1933 \\
\hline 16 & TaiYuan & 53772 & $37^{\circ} 47^{\prime}$ & $112^{\circ} 33^{\prime}$ & 777.9 & 1916 \\
\hline 17 & MuDanJiang & 54094 & $44^{\circ} 34^{\prime}$ & $129^{\circ} 36^{\prime}$ & 241.4 & 1909 \\
\hline 18 & ChangChun & 54161 & $43^{\circ} 53^{\prime}$ & $125^{\circ} 20^{\prime}$ & 236.8 & 1909 \\
\hline 19 & ShenYang & 54342 & $41^{\circ} 46^{\prime}$ & $123^{\circ} 26^{\prime}$ & 41.6 & 1905 \\
\hline 20 & BeiJing & 54511 & $39^{\circ} 56^{\prime}$ & $116^{\circ} 17^{\prime}$ & 54.0 & 1841 \\
\hline 21 & TianJin & 54527 & $39^{\circ} 06^{\prime}$ & $117^{\circ} 10^{\prime}$ & 3.3 & 1000 \\
\hline 22 & BaoDing & 54602 & $38^{\circ} 50^{\prime}$ & $115^{\circ} 34^{\prime}$ & 17.2 & 1913 \\
\hline 23 & DaLian & 54662 & $38^{\circ} 54^{\prime}$ & $121^{\circ} 38^{\prime}$ & 92.8 & 1904 \\
\hline 24 & YanTai & 54765 & $37^{\circ} 32^{\prime}$ & $121^{\circ} 24^{\prime}$ & 46.7 & 1886 \\
\hline 25 & IiNan & 54823 & $36^{\circ} 41^{\prime}$ & $116^{\circ} 59^{\prime}$ & 51.6 & 1916 \\
\hline 26 & QingDao & 54857 & $36^{\circ}\left(14^{\prime}\right.$ & $120^{\circ} 20^{\prime}$ & 76.0 & 1898 \\
\hline 27 & LaSa & 55591 & $29^{\circ} 42^{\prime}$ & $91^{\circ} 08^{\prime}$ & 3658.0 & 1935 \\
\hline 28 & ChengDu & 56294 & $30^{\circ} 40^{\prime}$ & $104^{\circ} 01^{\prime}$ & 506.1 & 1907 \\
\hline 29 & XiChang & 56571 & $27^{\circ} 54^{\prime}$ & $102^{\circ} 16^{\prime}$ & 1590.0 & 1924 \\
\hline 30 & TengChong & 56739 & $25^{\circ} 07^{\prime}$ & $98^{\circ} 29^{\prime}$ & 1647.8 & 1911 \\
\hline 31 & KunMing & 56778 & $25^{\circ} 01^{\prime}$ & $102^{\circ} 41^{\prime}$ & 1891.4 & 1901 \\
\hline 32 & TianShui & 57006 & $34^{\circ} 35^{\prime}$ & $105^{\circ} 45^{\prime}$ & 1131.7 & 1935 \\
\hline 33 & XiAn & 57036 & $34^{\circ} 18^{\prime}$ & $108^{\circ} 56^{\prime}$ & 396.9 & 1922 \\
\hline 34 & ZhengZhou & 57083 & $34^{\circ} 43^{\prime}$ & $113^{\circ} 39^{\prime}$ & 110.4 & 1930 \\
\hline 35 & HanZhong & 57127 & $33^{\circ} 04^{\prime}$ & $107^{\circ} 12^{\prime}$ & 508.4 & 1932 \\
\hline 36 & YiChang & 57461 & $30^{\circ} 42^{\prime}$ & $111^{\circ} 18^{\prime}$ & 133.1 & 1882 \\
\hline 37 & WuHan & 57494 & $30^{\circ} 37^{\prime}$ & $114^{\circ} 08^{\prime}$ & 23.3 & 1880 \\
\hline 38 & ChongQing & 57516 & $29^{\circ} 35^{\prime}$ & $106^{\circ} 28^{\prime}$ & 259.1 & 1891 \\
\hline 39 & ChangSha & 57679 & $28^{\circ} 12^{\prime}$ & $113^{\circ}\left(05^{\prime}\right.$ & 44.9 & 1909 \\
\hline 40 & ZhiJiang & 57745 & $27^{\circ} 27^{\prime}$ & $109^{\circ} 41^{\prime}$ & 272.2 & 1938 \\
\hline 41 & GuiYang & 57816 & $26^{\circ} 35^{\prime}$ & $106^{\circ} 43^{\prime}$ & 1071.2 & 1920 \\
\hline 42 & XuZhou & 58027 & $34^{\circ} 17^{\prime}$ & $11^{\prime \prime} 7^{\circ}\left(19^{\prime}\right.$ & 41.0 & 1915 \\
\hline 43 & QingJiang & 58144 & $33^{\circ} 36^{\prime}$ & $119^{\circ} 02^{\prime}$ & 17.5 & 1913 \\
\hline
\end{tabular}


10

Table 3. (continued)

\begin{tabular}{|c|c|c|c|c|c|c|}
\hline & Station name & $\begin{array}{l}\text { Station } \\
\text { number }\end{array}$ & Latitude & Longltude" & Elevation (m) & $\begin{array}{l}\text { 3eginning of } \\
\text { period of } \\
\text { recordd }\end{array}$ \\
\hline 44 & NanJing & 582.38 & $32^{\circ}\left(03^{\prime}\right.$ & $118^{\circ} 47^{\prime}$ & 8.9 & 1905 \\
\hline 45 & ShangHai & 58367 & $31^{\circ} 10^{\prime}$ & $121^{\circ} 26^{\prime}$ & 4.5 & 1871 \\
\hline 46 & AnQing & 58424 & $30^{\circ} 32^{\prime}$ & $117^{\circ} 03^{\prime}$ & 19.8 & 1931 \\
\hline 47 & HangZhou & 58457 & $30^{\circ} 14^{\prime}$ & $120^{\circ} 10^{\prime}$ & 41.7 & 1904 \\
\hline 48 & NanChang & 586066 & $28^{\circ} 36^{\prime}$ & $115^{\circ} 55^{\prime}$ & 46.7 & 1929 \\
\hline 49 & QuZhou & 586.33 & $28^{\circ} 58^{\prime}$ & $118^{\circ} 53^{\prime}$ & 66.9 & 1950 \\
\hline 50 & WenZhou & 58659 & $28^{\circ} 01^{\prime}$ & $120^{\circ} 40^{\prime}$ & 7.1 & 188.3 \\
\hline 51 & FuZhou & 58847 & $26^{\circ} 05^{\prime}$ & $119^{\circ} 17^{\prime}$ & 83.8 & 1880 \\
\hline 52 & YongAn & 58921 & $25^{\circ} 58^{\prime}$ & $117^{\circ} 21^{\prime}$ & 206.0 & 1938 \\
\hline 5.3 & LiuZhou & 59() 46 & $24^{\circ} 28^{\prime}$ & $109^{\circ} 22^{\prime}$ & 97.6 & 1936 \\
\hline 54 & XlaMen & 59134 & $24^{\circ} 29^{\prime}$ & $118^{\circ} 04^{\prime}$ & 139.4 & 1886 \\
\hline 55 & WuZhou & 59265 & $23^{\circ} 29^{\prime}$ & $111^{\circ} 18^{\prime}$ & 119.2 & 1898 \\
\hline 56 & GuangZhou & 59287 & $23^{\circ}() 8^{\prime}$ & $113^{\circ} 19^{\prime}$ & 6.6 & 1908 \\
\hline 57 & ShanTou & 59316 & $23^{\circ} 24^{\prime}$ & $116^{\circ} 41^{\prime}$ & 1.2 & 1880 \\
\hline 58 & NanNing & 59431 & $22^{\circ} 49^{\prime}$ & $108^{\circ} 21^{\prime}$ & 72.2 & 1907 \\
\hline 59 & Zhanjiang & 59658 & $21^{\circ} 13^{\prime}$ & $110^{\circ} 24^{\prime}$ & 25.3 & 1913 \\
\hline 60) & HaiKou & 59758 & $20^{\circ} 02^{\prime}$ & $110^{\circ} 21^{\prime}$ & 14.1 & 1912 \\
\hline
\end{tabular}

"North

${ }^{b}$ East

' Obtained from data base, station histories may give a different year. 

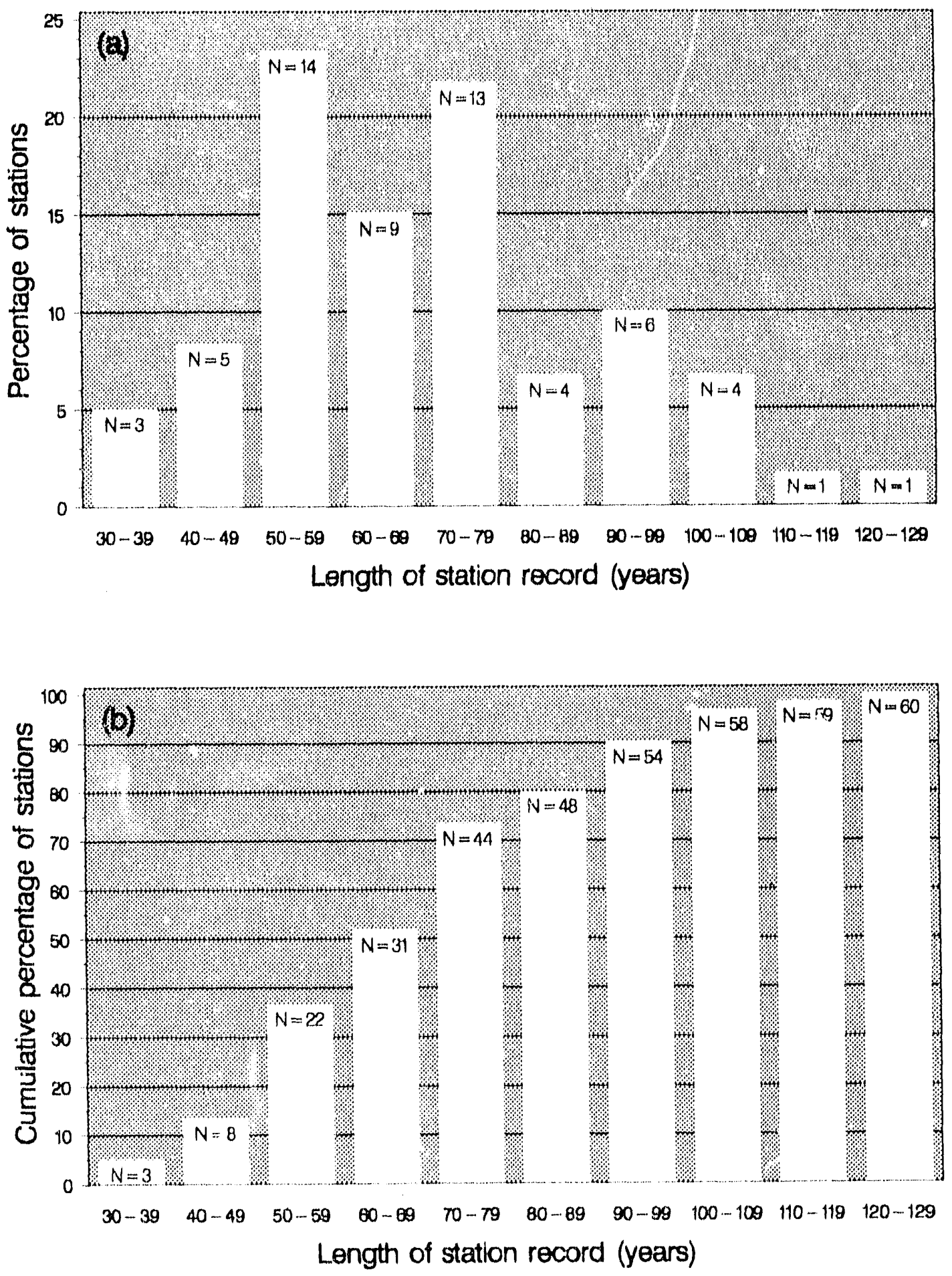

Figg. 1. Percentage (a) and cumulative percentage (b) of stations from the i'RC (6)-station climate network with given record lengths. 


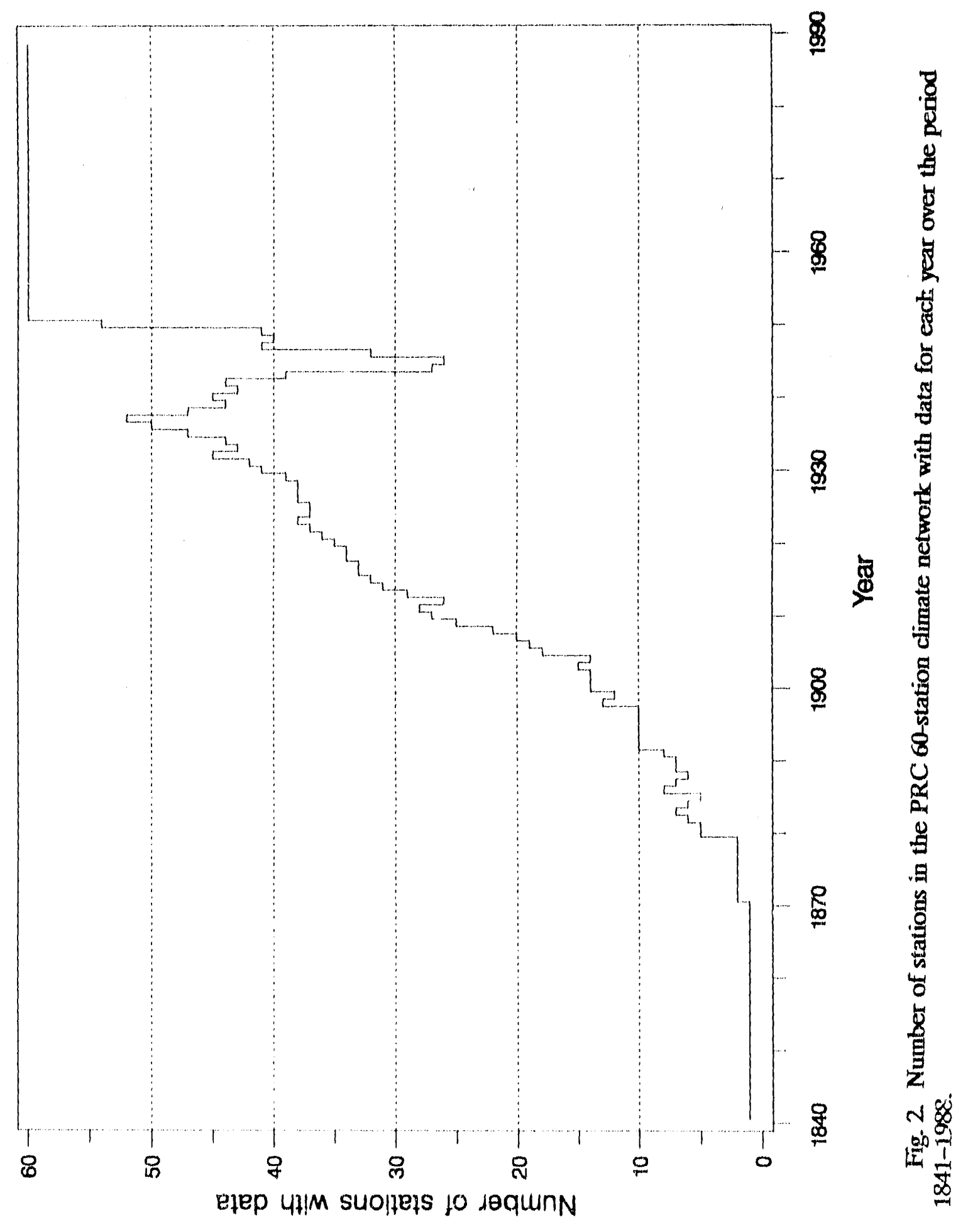


Tablo 4. Gaps in the periods of record of stations in the PRC 6()-station climate network

\begin{tabular}{|c|c|c|c|c|c|}
\hline \multirow[b]{2}{*}{1} & \multirow{2}{*}{ Station name } & \multirow{2}{*}{ Stution number } & \multicolumn{3}{|c|}{ Ycars with no data } \\
\hline & & & $1933-1934$ & $1943-1949$ & \\
\hline 2 & NenJiang & 50557 & $1946-1948$ & & \\
\hline 3 & $\mathrm{BoKeTu}$ & 506.32 & $1933-1950$ & & \\
\hline 4 & QiQiHaEr & 50745 & $1944-1948$ & & \\
\hline 5 & HaErBin & 50953 & $1907-1908$ & $1944-1948$ & \\
\hline 6 & Yi Ning & $51431^{a}$ & & & \\
\hline 7 & WuLuMuQi & 5146.3 & 1909 & $1912-1929$ & $1931-1940$ \\
\hline 8 & $\mathrm{HaMi}$ & $52203^{n}$ & & & \\
\hline 9 & Jiu Quan & $52533^{a}$ & & & \\
\hline 10 & ZhangYe & 52652 & $1942-1950$ & & \\
\hline 11 & XiNing & $52866^{a}$ & & & \\
\hline 12 & LanZhou & $52889^{4}$ & & & \\
\hline 13 & HuHeHaoTe & 53463 & 1938 & $1944-1945$ & \\
\hline 14 & YinChuan & 53614 & $1939-1949$ & & \\
\hline 15 & YuLin & 53646 & 1949 & & \\
\hline 16 & TaiYuan & 53772 & 1938 & $1944-1945$ & 1949 \\
\hline 17 & MuDanJiang & 54094 & $1933-1936$ & $1944-1948$ & \\
\hline 18 & ChangChun & 54161 & 1944-1946 & & \\
\hline 19 & ShenYang & 54342 & $1944-1946$ & & \\
\hline \multirow[t]{3}{*}{ 20) } & BeiJing & 54511 & $1856-1858$ & $1862-1867$ & 1885 \\
\hline & & & $1887-1888$ & $1901-1902$ & 1904 \\
\hline & & & 1909 & $1912-1913$ & $1938-1939$ \\
\hline 21 & TianJin & 54527 & 1935 & & \\
\hline 22 & BaoDing & 54602 & $1940-1943$ & $1944-1949$ & \\
\hline 2.3 & DaLian & $54662^{\prime \prime}$ & & & \\
\hline 24 & YanTai & 54765 & $1944-1949$ & & \\
\hline 25 & JiNan & $54823^{a}$ & & & \\
\hline 26 & Qing D:io & $54857^{a}$ & & & \\
\hline 27 & 1.46 a & 55591 & 1939 & 1950 & \\
\hline$x$ & (1):ng!lu & 56294 & $1912-1922$ & $1930-1931$ & \\
\hline 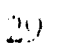 & sichang & $56571^{a}$ & & & \\
\hline 30 & 'TengChong & 56739 & $1942-1950$ & & \\
\hline 31 & KunMing & 56778 & $1904-1950$ & $1915-1917$ & \\
\hline 32 & TianShui & 57006 & 1941 & & \\
\hline 33 & XiAn & $57(1) 36$ & $1928-1930$ & & \\
\hline 34 & ZhengZhou & $57(1) 83$ & $1939-1949$ & & \\
\hline 35 & HanZhong & 57127 & 1946 & & \\
\hline 36 & YiChang & 57461 & $1939-1946$ & & \\
\hline 37 & Wultan & 57494 & 1884 & $1941-1946$ & \\
\hline 38 & ChongQing & $57516^{\circ}$ & & & \\
\hline 39 & ChangSha & 57679 & 1939 & $1941-1945$ & \\
\hline
\end{tabular}


Table 4. (continued)

\begin{tabular}{llllll}
\hline & Station name & Station number & & \multicolumn{2}{c}{ Years with no data } \\
\hline & & & & & \\
40 & ZhiJiang & $57745^{\circ}$ & & & \\
41 & GuiYang & $57816^{\circ}$ & & & $1944-1948$ \\
42 & XuZhou & 58027 & $1924-1925$ & 1938 & \\
43 & QingJiang & 58144 & $1924-1927$ & $1939-1946$ & 1949 \\
44 & NanJing & 58238 & $1938-1945$ & & \\
45 & ShangHai & $58367^{\circ}$ & & & \\
46 & AnQing & 58424 & $1939-1941$ & $1943-1949$ & \\
47 & HangZhou & 58457 & $1938-1941$ & $1943-1944$ & $1948-1949$ \\
48 & NanChang & 58606 & $1939-1945$ & & \\
49 & QuZhou & $58633^{\circ}$ & & & \\
50 & WenZhou & 58659 & 1885 & $1943-1945$ & \\
51 & FuZhou & 58847 & $1886-1891$ & 1899 & \\
52 & YongAn & 58921 & 1949 & & \\
53 & LiuZhou & $59046^{\circ}$ & & & \\
54 & XiaMen & 59134 & $1888-1891$ & $1943-1946$ & \\
55 & WuZhou & 59265 & 1945 & & \\
56 & GuangZhou & 59287 & $1944-1946$ & & \\
57 & ShanTou & 59316 & $1944-1949$ & & \\
58 & NanNing & 59431 & $1916-1920$ & & \\
59 & ZhanJiang & 59658 & $1940-1949$ & & \\
60 & HaiKou & 59758 & $1944-1946$ & & \\
& & & & & \\
\hline
\end{tabular}

"At least pirtial dala are available for all years in the station's period of record. 
15

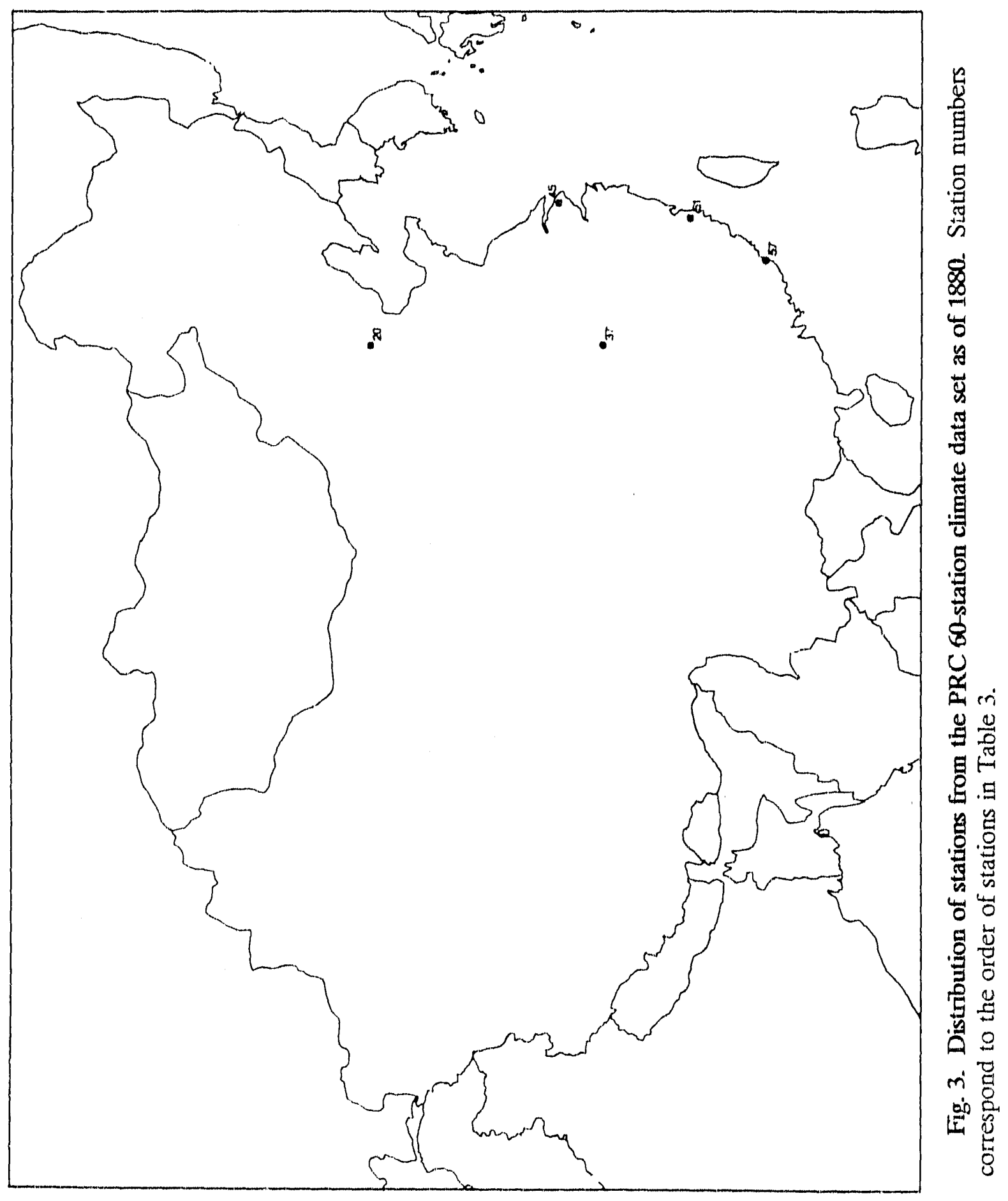


16

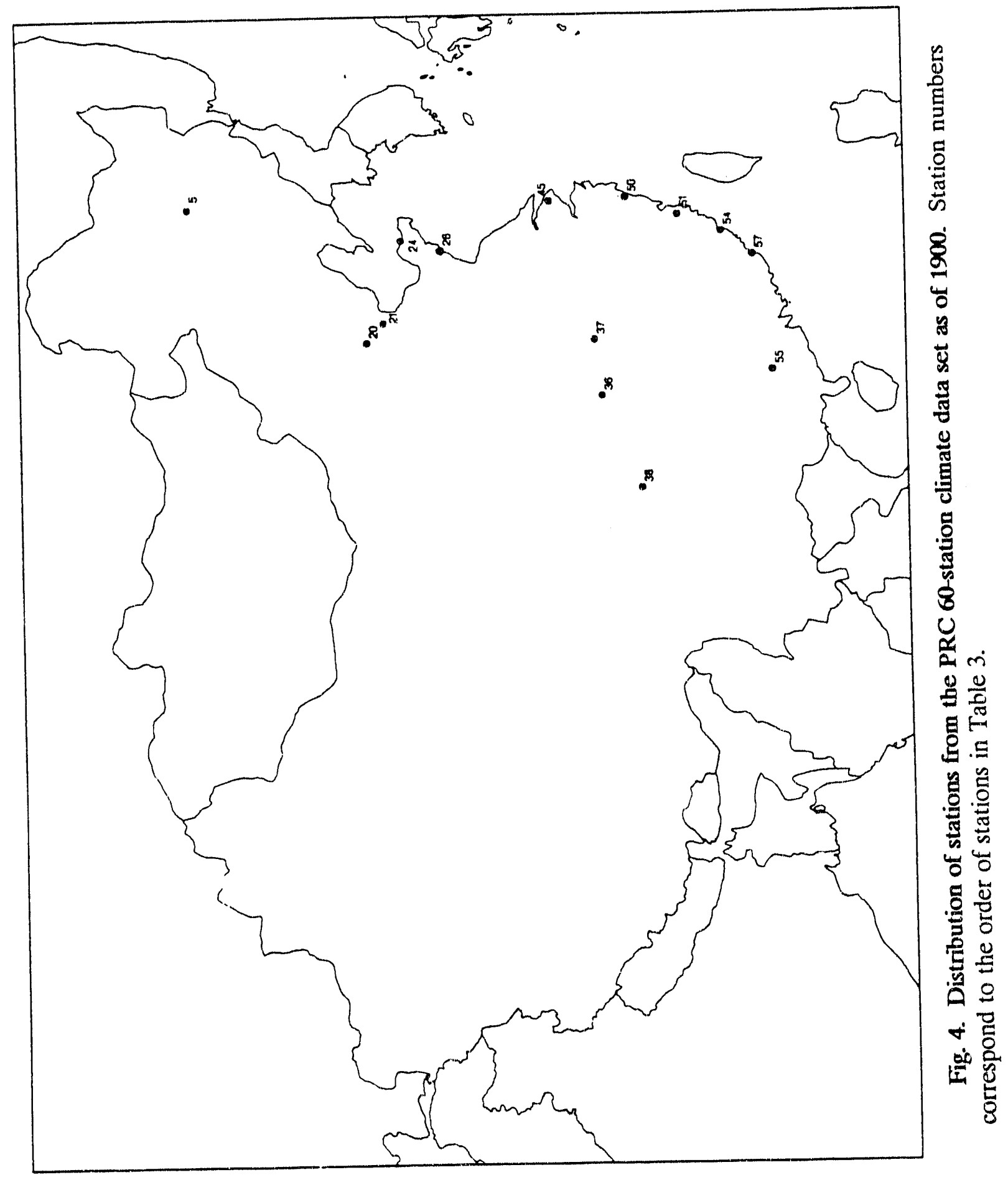




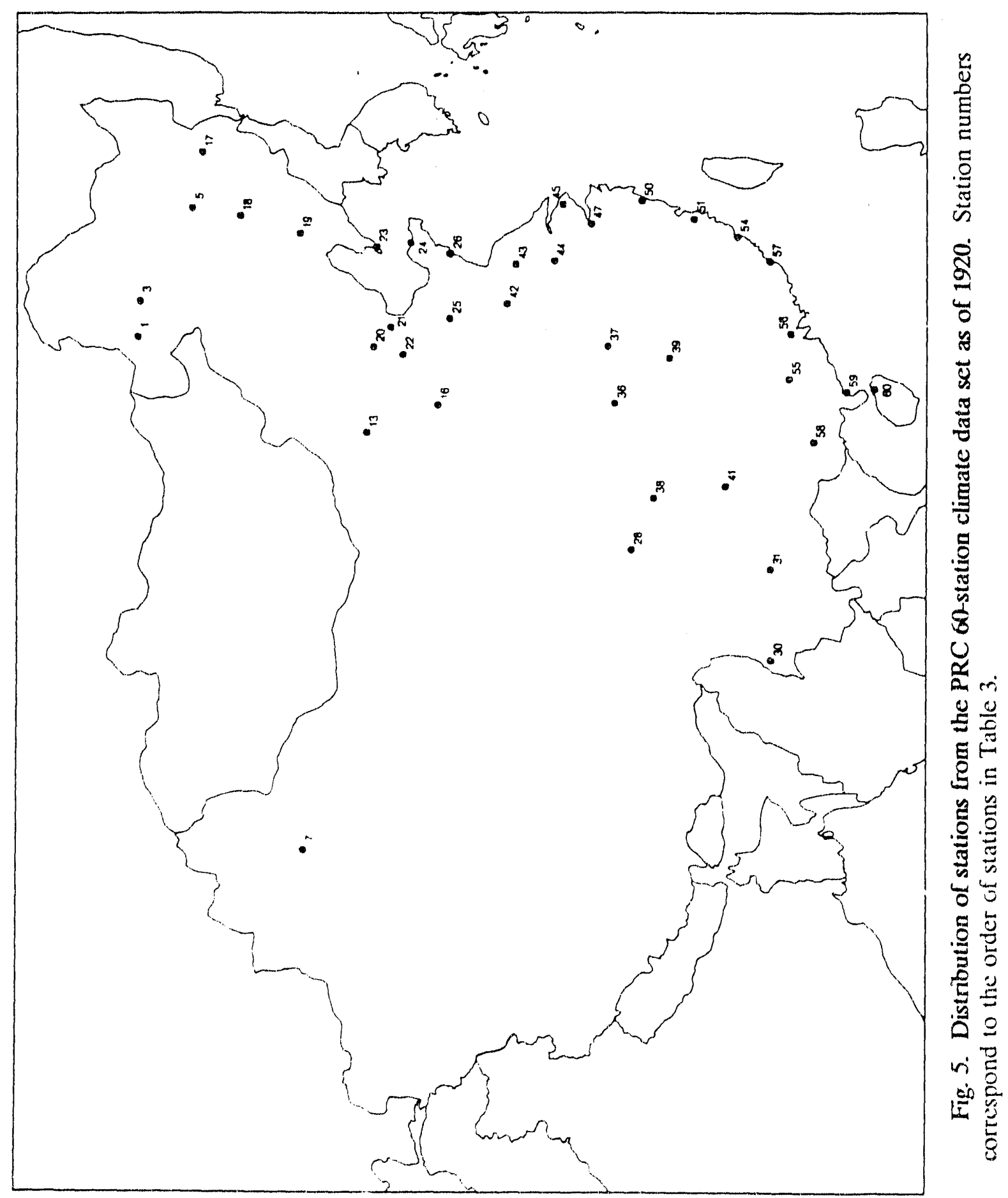

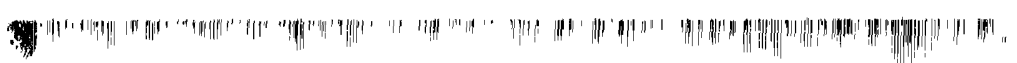




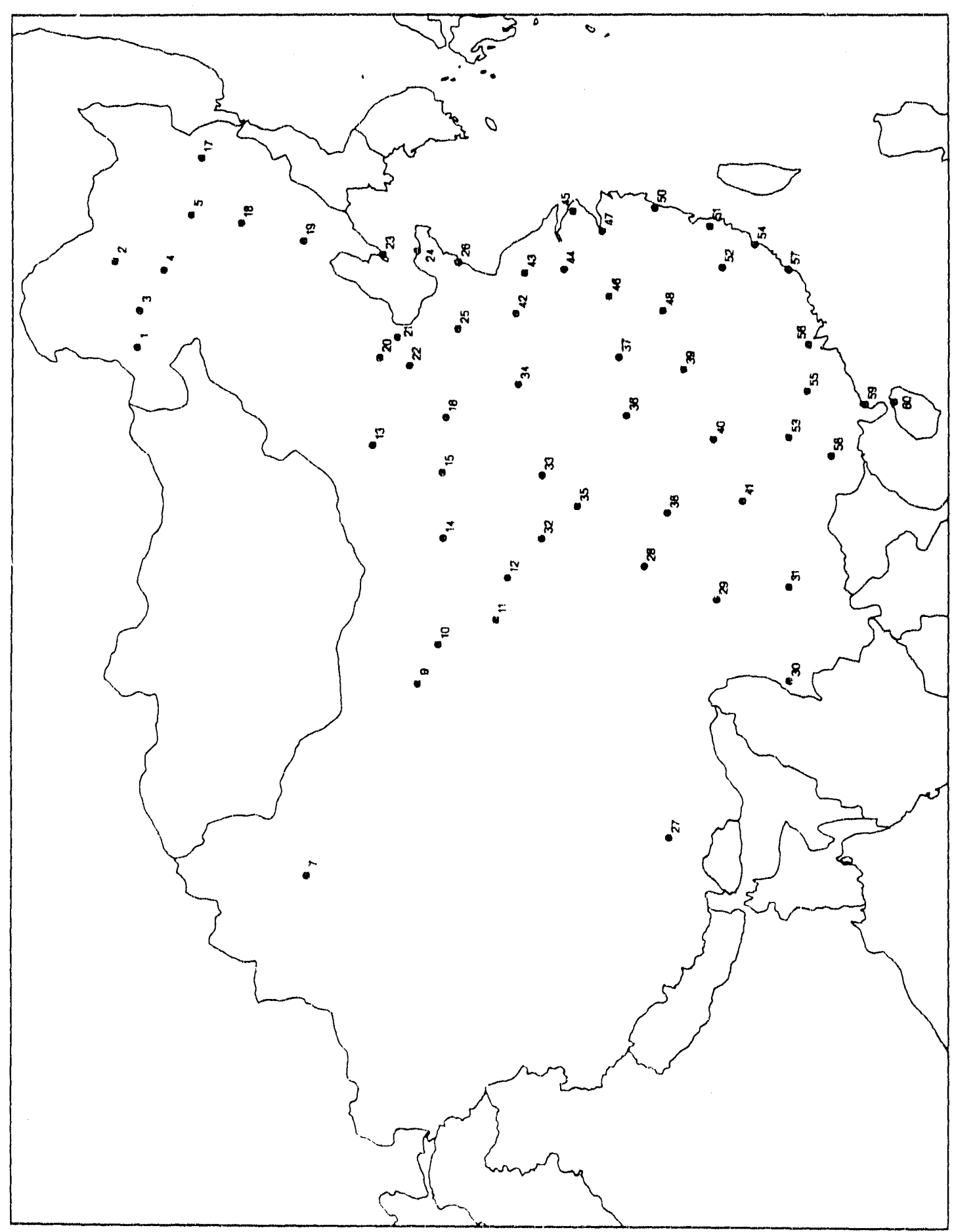

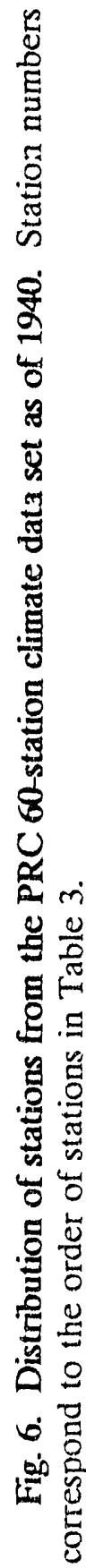




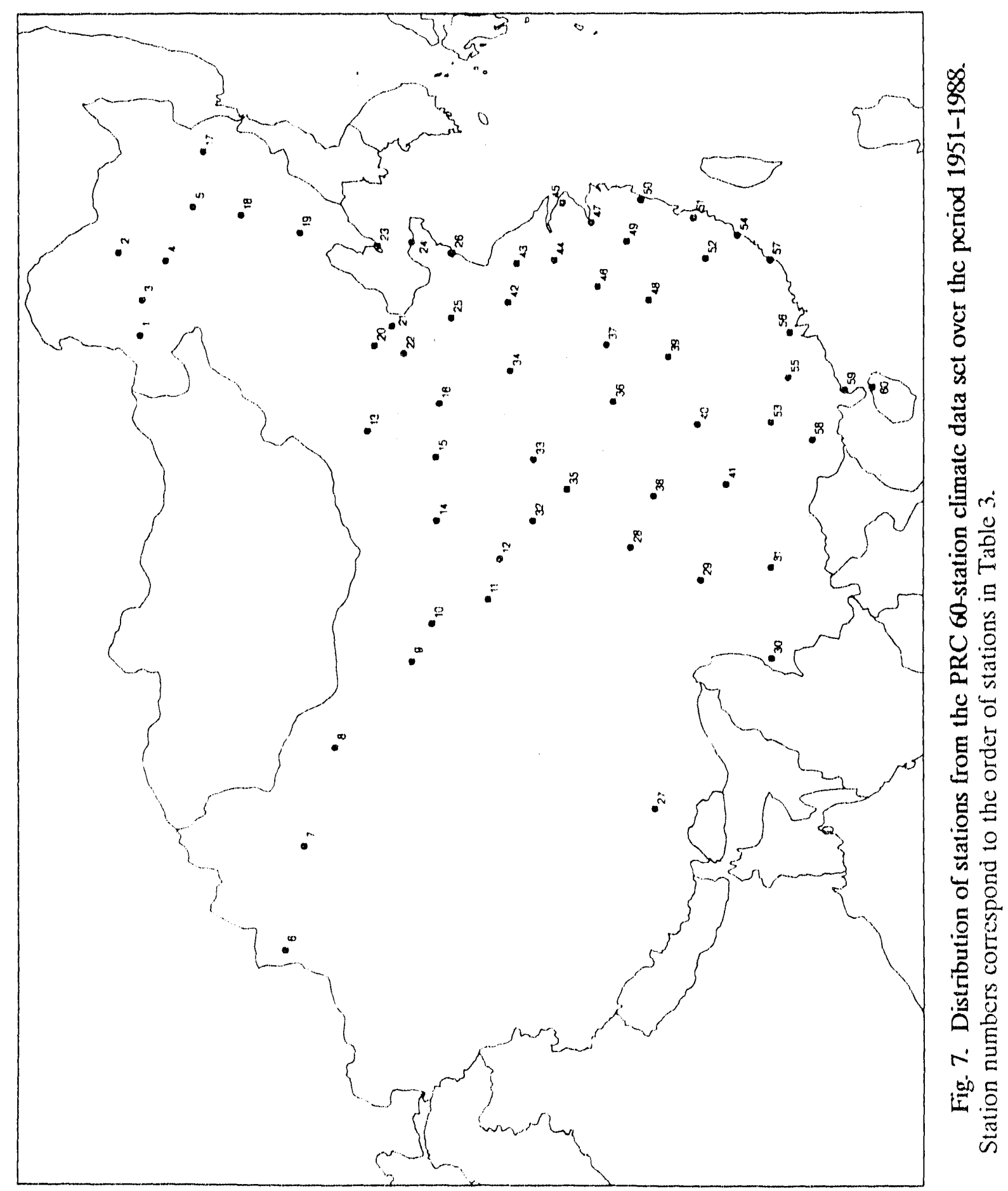




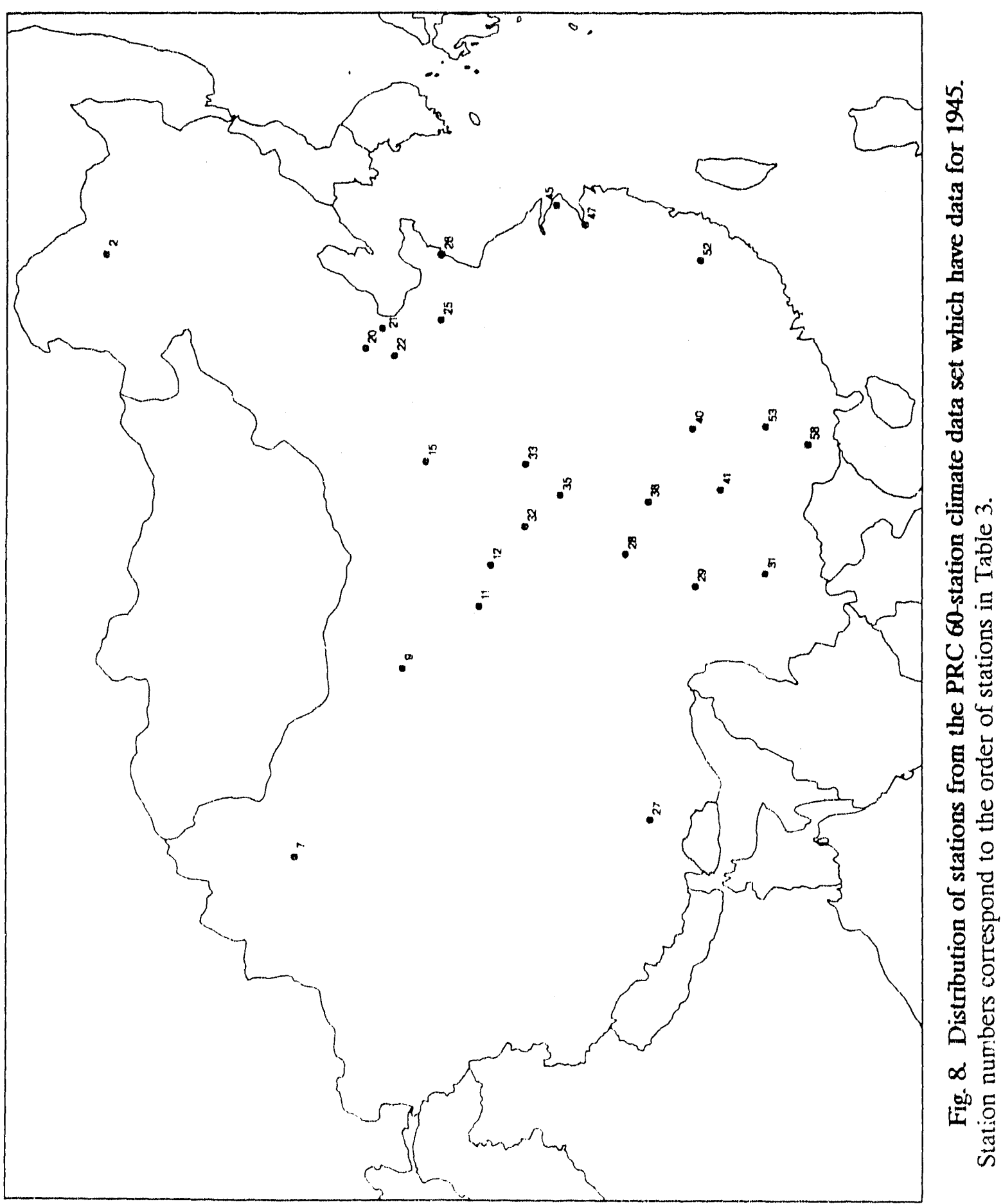




\section{5-STATION NETWORK}

The data from the 205-station network contain two variables: monthly mean temperature and total monthly precipitation. The data are stored in two files, one with temperatures (in tenths of degrees Celsius) and the other with precipitation totals (in tenths of millimeters), samples of which are shown in Tables 5 and 6, respectively. Each record of a file contains data from one year: the WMO station number and year followed by twelve monthly data values. Missing values are represented by "-9999". An inventory of the 205 stations is given in Table 7. The temperature data dale back to 1907 (Jingzhou, No. 57476), and the precipitation data to 1880 (Wuhu, No. 58334). Temperature and precipitation records from 202 stations extend through 1988. Records from Gecrshiquanhe (No.55228), Hekou (No. 56989), and Lingling (No. 57866) extend through 1982, 1980, and 1983, respectively.

As with the 6()-station network, pereentage plots have been prepared for the 205-station network showing the relative length of station records. These are shown separately for temperature records (Fig. 9) and precipitation records (Fig. 10). The ranges of station record length reflect the number of years for which the station has at least partial data, which is often less than the number of years since the station opened. As with the 6()-station network, this has much to do with World War II's effect on station operations, as illustrated in Fig. 11, which shows the number of stations with temperature and precipitation data for each year over the period 1880-1988. (Because of their relatively small number, years without data have been left in these data sets rather than detailing them separately as with the 60-station data set.) Figures 9 and 10 show that for both temperature and precipitation data, the most typical length of record ranges between $30-40$ years, with a relatively small share of stations 29 stations $(\sim 15 \%)$ for temperature data; 24 stations $(-12 \%)$ for precipitation datal having records for 50 or more ycars. It is evident from comparing Figs. 9 and 10 with Fig. 1 that the 6()-station data set offers more truly long-term records and, as previously noted, contains temperature and/or precipitation data from the beginning of each station record.

Maps depicting the evolution of the 205-station temperature and precipitation network are given in Figs. 12-17. Figures 12-16 show, for temperature and precipitation data individually, the locations of stations which had been opened as of 1900), 1920, and 1940. Each station shown on these maps does not necessarily have data for that particular year. Figure 17 shows the network in 1961, the first year all 205 stations had temperature and precipitation data. Numbers plotted on these maps at station locations correspond to the station identification numbers at the left of Table 7. The locations of stations actually having data for 1945 (one of two especially affected years in the era of decreased eoverage caused by World War II) are shown separately for temperature and precipitation data in Figs. 18 and 19. Unfortunately, station histories are not currently available for any stations in the 205-station network: therefore, details regarding instrumentation, collection methods, changes in station location or observing times, and official data sources are not known. 
Table 5. Sample listing of the PRC 205-station monthly moan temperature data set ${ }^{a}$

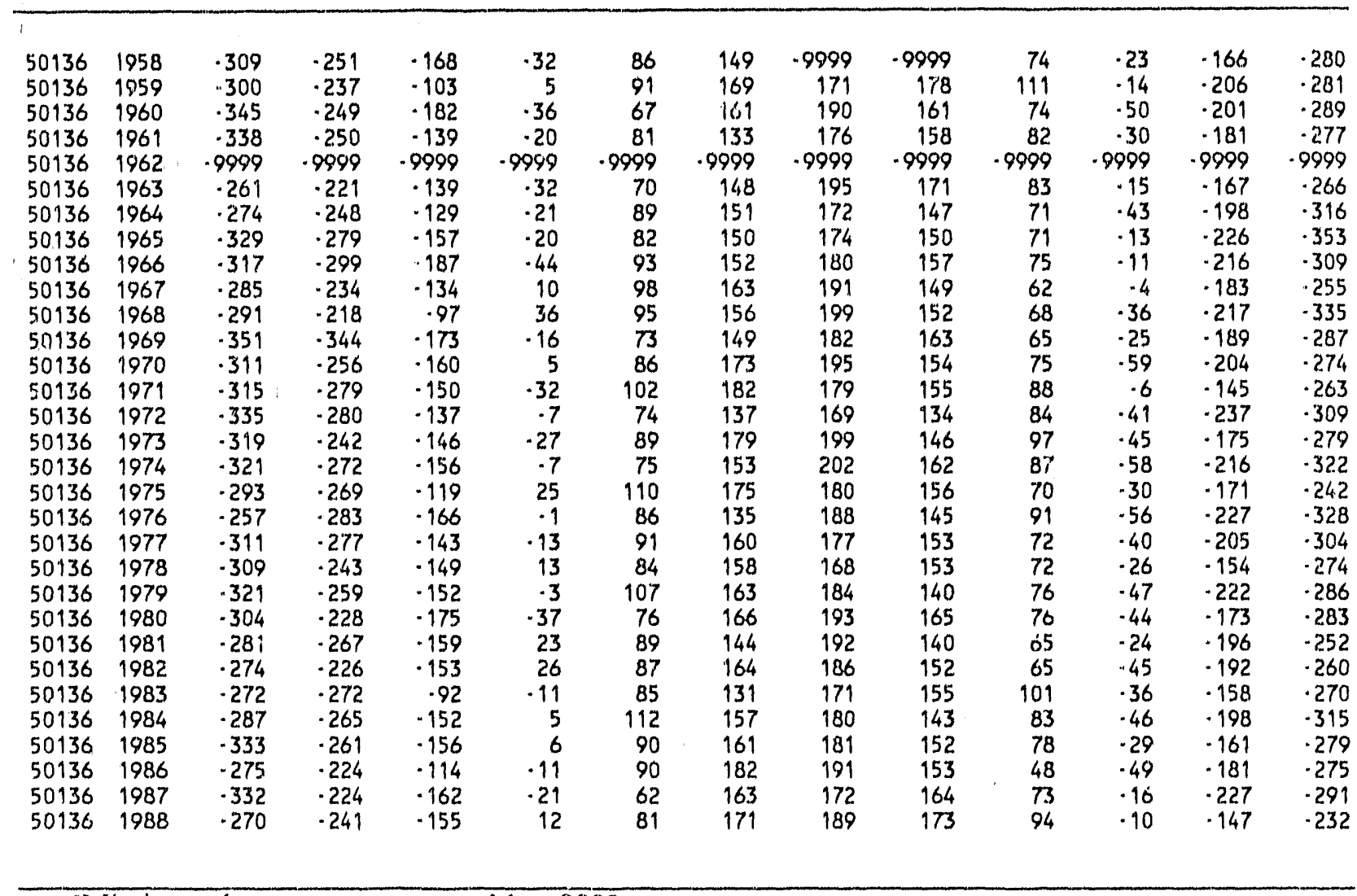

${ }^{a}$ Missing values are represented by -9999 . 
Table 6. Sample listing of the PRC 205-station monthly precipitation data set

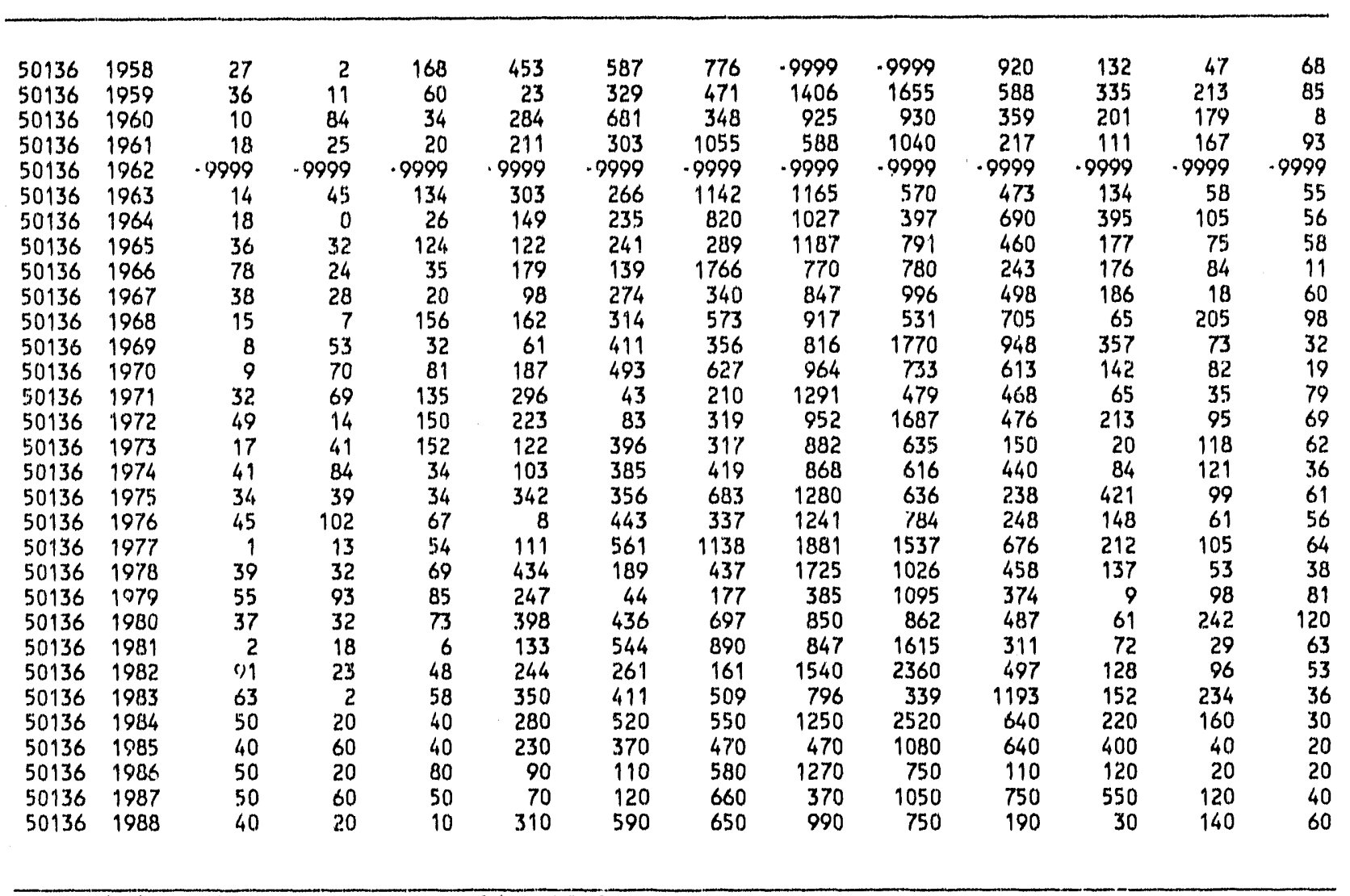

${ }^{a}$ Missing values are represented by -9999 . 
Table 7. Inventory of stations in the PRC 205-station temperature and precipitation network

\begin{tabular}{|c|c|c|c|c|c|c|c|}
\hline & \multirow[b]{2}{*}{ Station name } & \multirow{2}{*}{$\begin{array}{l}\text { Station } \\
\text { number }\end{array}$} & \multirow[b]{2}{*}{ Latlude } & \multirow[b]{2}{*}{ Longliude" } & \multirow[b]{2}{*}{ Elcvatlon ${ }^{c}$} & \multicolumn{2}{|c|}{$\begin{array}{l}\text { First year } \\
\text { of record } \\
\end{array}$} \\
\hline & & & & & & Temp. & Precip. \\
\hline 1 & Humamehe & 50136 & $53^{\circ} 28^{\prime}$ & $122^{\circ} 22^{\prime}$ & 296.0 & 1958 & 1958 \\
\hline 2 & Huma & 50353 & $51^{\circ} 43^{\prime}$ & $126^{\circ} 39^{\prime}$ & 177.4 & 1954 & 1954 \\
\hline 3 & Xuguitu Qi Tulihe & 50434 & $50^{\circ} 29^{\prime}$ & $121^{\circ} 41^{\prime}$ & 732.6 & 1957 & 1957 \\
\hline 4 & Sunw'u & 50564 & $49^{\circ} 26^{\prime}$ & $127^{\circ} 21^{\prime}$ & 234.5 & 1954 & 1954 \\
\hline 5 & Keshan & 50658 & $48^{\circ} 03^{\prime}$ & $125^{\circ} 53^{\prime}$ & 236.9 & 1936 & 1936 \\
\hline 6 & Horqing Youyi Qiang & 50727 & $47^{\circ} 10^{\prime}$ & $119^{\circ} 57^{\prime}$ & 1027.2 & 1953 & 19.38 \\
\hline 7 & Hailun & 50756 & $47^{\circ} 26^{\prime}$ & $126^{\circ} 58^{\prime}$ & 239.2 & 1933 & 1934 \\
\hline 8 & Yichun & 50774 & $47^{\circ} 43^{\prime}$ & $128^{\circ} 54^{\prime}$ & 231.3 & 1956 & 1956 \\
\hline 9 & Fujin & 50788 & $47^{\circ} 14^{\prime}$ & $131^{\circ} 59^{\prime}$ & 64.2 & 1936 & 1936 \\
\hline 10 & Anda & 50854 & $46^{\circ} 23^{\prime}$ & $125^{\circ} 19^{\prime}$ & 149.3 & 1914 & 1914 \\
\hline 11 & Dong Ujimqin Qi & 50915 & $45^{\circ} 31^{\prime}$ & $116^{\circ} 58^{\prime}$ & 838.7 & 1956 & 1956 \\
\hline 12 & Qian Gorlos & 50949 & $45^{\circ} 07^{\prime}$ & $124^{\circ} 50^{\prime}$ & 134.7 & 1953 & 1953 \\
\hline 13 & Tonghe & 50963 & $45^{\circ} 58^{\prime}$ & $128^{\circ} 44^{\prime}$ & 108.6 & 1953 & 1936 \\
\hline 14 & Jixi & 50978 & $45^{\circ} 17^{\prime}$ & $130^{\circ} 57^{\prime}$ & 232.8 & 1949 & 1951 \\
\hline 15 & Altay & 51076 & $47^{\circ} 44^{\prime}$ & $88^{\circ} 05^{\prime}$ & 735.3 & 1938 & 1954 \\
\hline 16 & Tacheng & 51133 & $46^{\circ} 44^{\prime}$ & $83^{\circ}(0)^{\prime}$ & 548.0 & 1940 & 1954 \\
\hline 17 & Hoboksar & 51156 & $46^{\circ} 47^{\prime}$ & $85^{\circ} 43^{\prime}$ & 1291.6 & 1954 & 1954 \\
\hline 18 & Jinghe & 51334 & $44^{\circ} 37^{\prime}$ & $82^{\circ} 54^{\prime}$ & 320,1 & 1953 & 1953 \\
\hline 19 & Qitai & 51379 & $44^{\circ} 01^{\prime}$ & $89^{\circ} 34^{\prime}$ & 793.6 & 1952 & 1952 \\
\hline 20 & lami Qiflaojing & 51495 & $43^{\circ} 29^{\prime}$ & $91^{\circ} 38^{\prime}$ & 8732 & 1953 & 1953 \\
\hline 21 & Turpan & 51573 & $42^{\circ} 56^{\prime}$ & $89^{\circ} 12^{\prime}$ & 34.5 & 1952 & 1952 \\
\hline 22 & Kuqa & 51644 & $41^{\circ} 43^{\prime}$ & $82^{\circ} 57^{\prime}$ & 1099.0 & 1951 & 1951 \\
\hline 23 & Kashi & 51709 & $34^{\circ} 28^{\prime}$ & $75^{\circ} 59^{\prime}$ & 1288.7 & 1951 & 1951 \\
\hline 24 & Bachu & 51716 & $39^{\circ} 48^{\prime}$ & $78^{\circ} 34^{\prime}$ & 1116.5 & 1954 & 1954 \\
\hline 25 & Ruogiang & 51777 & $39^{\circ} 02^{\prime}$ & $88^{\circ} 10^{\prime}$ & 888.3 & 1954 & 1954 \\
\hline 26 & Shache & 51811 & $38^{\circ} 26^{\prime}$ & $77^{\circ} 16^{\prime}$ & 1231.2 & 1954 & 1954 \\
\hline 27 & Hotan & 51828 & $37^{\circ} 08^{\prime}$ & $79^{\circ} 56^{\prime}$ & 1374.6 & 1942 & 1954 \\
\hline 28 & Qicmo & 51855 & $38^{\circ} 09^{\prime}$ & $85^{\circ} 33^{\prime}$ & 1247.5 & 1954 & 1954 \\
\hline 29 & Ejin Qi & 52267 & $41^{\circ} 57^{\prime}$ & $101^{\circ} 04^{\prime}$ & 940.5 & 1960 & 1960 \\
\hline 30 & Yemajie & 5232.3 & $41^{\circ} 35^{\prime}$ & $96^{\circ} 53^{\prime}$ & 1962.7 & 1958 & 1958 \\
\hline 31 & Dunhuang & 52418 & $40^{\circ} 09^{\prime}$ & $94^{\circ} 41^{\prime}$ & 1138.7 & 1938 & 1951 \\
\hline 32 & Anxi & 52424 & $40^{\circ} 32^{\prime}$ & $95^{\circ} 46^{\prime}$ & 1170.8 & 1939 & 1951 \\
\hline 33 & Yumenzhen & 52436 & $40^{\circ} 16^{\prime}$ & $97^{\circ} 02^{\prime}$ & 1526.0 & 1953 & 1953 \\
\hline 34 & Lengh & 52602 & $38^{\circ} 50^{\prime}$ & $93^{\circ} 23^{\prime}$ & 2733.0 & 1957 & 1957 \\
\hline 35 & Qilian Tuole & 52633 & $38^{\circ} 49^{\prime}$ & $98^{\circ} 25^{\prime}$ & 3360.7 & 1957 & 1957 \\
\hline 36 & Minqin & 52681 & $38^{\circ} 38^{\prime}$ & $10.3^{\circ} 05^{\prime}$ & 1367.0 & 1953 & 1953 \\
\hline 37 & Da Qajdam & 52713 & $37^{\circ} 51^{\prime}$ & $95^{\circ} 22^{\prime}$ & 317.3 .2 & 1957 & 1957 \\
\hline 38 & Tianzhu Wushaoling & 52787 & $37^{\circ} 12^{\prime}$ & $102^{\circ} 5 ?^{\prime}$ & 3045.1 & 1951 & 1951 \\
\hline 39 & Golmud & 52818 & $36^{\circ} 25^{\prime}$ & $94^{\circ} 54^{\prime}$ & 2807.7 & 1956 & 1956 \\
\hline 40 & Dulan & 52836 & $36^{\circ} 18^{\prime}$ & $98^{\circ}(6)^{\prime}$ & 3191.1 & 1940 & 1954 \\
\hline 41 & Uulan Caka & 52842 & $36^{\circ} 47^{\prime}$ & $99^{\circ} 05^{\prime}$ & 3087.6 & 1956 & 1956 \\
\hline
\end{tabular}


Table 7. (continued)

\begin{tabular}{|c|c|c|c|c|c|c|c|}
\hline & \multirow[b]{2}{*}{ Station name } & \multirow{2}{*}{$\begin{array}{l}\text { Station } \\
\text { number }\end{array}$} & \multirow[b]{2}{*}{ Lallitude" } & \multirow[b]{2}{*}{ Longltude" } & \multirow[b]{2}{*}{ Elevallon' } & \multicolumn{2}{|c|}{$\begin{array}{l}\text { First year } \\
\text { of record }\end{array}$} \\
\hline & & & & & & Temp). & Precip. \\
\hline 42 & Gonghe & 52856 & $36^{\circ} 16^{\prime}$ & $1(x)^{\circ} 37^{\prime}$ & $28.7 .5,0$ & 1953 & 1953 \\
\hline 43 & L/nxia & 52984 & $35^{\circ} .35^{\prime}$ & $1(1) 3^{\circ} 11^{\prime}$ & 1917.0 & 194.3 & 1951 \\
\hline 44 & Tongwel Huallaling & 52996 & $35^{\circ} 23^{\prime}$ & $105^{\circ}(x)^{\prime}$ & $24.50,6$ & 1943 & 1951 \\
\hline 4.5 & Ercnhot & 531168 & $43^{\circ} 39^{\prime}$ & $111^{\circ} 58^{\prime}$ & 964.7 & 1956 & 1956 \\
\hline 46 & Abag Ql & 5.3192 & $44^{\circ}\left(11^{\prime}\right.$ & $114^{\circ} 57^{\prime}$ & 1126.1 & 1953 & 1953 \\
\hline 47 & Sonid Youql & 53276 & $42^{\circ} 24^{\prime}$ & $112^{\circ} .54^{\prime}$ & 11.50 .5 & 1953 & 195.3 \\
\hline 48 & Urad Zhongyl & 533336 & $41^{\circ} .34^{\prime}$ & $108^{\circ} 31^{\prime}$ & 1288.2 & 1954 & 195. \\
\hline 49 & Darhan Muminggan & 53.3 .52 & $41^{\circ} 42^{\prime}$ & $110^{\circ} 26^{\prime}$ & 1375.9 & 1939 & 1954 \\
\hline 50 & Huade & 53391 & $41^{\circ} .54^{\prime}$ & $114^{\circ}(x)^{\prime}$ & 1482.5 & 1953 & 1953 \\
\hline 51 & Datong & 53487 & $40^{\circ} 00^{\prime}$ & $113^{\circ} 20^{\prime}$ & 1067.2 & 1921 & 1919 \\
\hline 52 & Alxa Yougi Jartal & 5.35012 & $39^{\circ} 47^{\prime}$ & $105^{\circ} 45^{\prime}$ & 10.31 .8 & 1955 & 1955 \\
\hline 53 & Otog Q1 & 53529 & $39^{\circ} 06^{\prime}$ & $107^{\circ} 59^{\prime}$ & $1.38(0.3$ & 1955 & 1955 \\
\hline 54 & Wutaishan & 53588 & $39^{\circ} 02^{\prime}$ & $113^{\circ} 32^{\prime}$ & 2895.8 & 1956 & 1956 \\
\hline 55 & Woixian & 53593 & $39^{\circ} 5()^{\prime}$ & $114^{\circ} 34^{\prime}$ & 909.5 & 1954 & 1922 \\
\hline 56 & Alxa Zuopl & $536(1) 2$ & $38^{\circ} 50^{\prime}$ & $1(1) 5^{\circ} 40^{\prime}$ & 1561.4 & 1953 & 1953 \\
\hline 57 & Xingxian & 53664 & $38^{\circ} 28^{\prime}$ & $111^{\circ} \mathrm{u8^{ \prime }}$ & 1012.6 & 1921 & 1955 \\
\hline 58 & Zhongning & 53705 & $37^{\circ} 29^{\prime}$ & $\left.105^{\circ} 4\right)^{\prime}$ & 1183.3 & 1939 & 1953 \\
\hline 59 & Yanchi & 53723 & $37^{\circ} 47^{\prime}$ & $10)^{\circ} 24^{\prime}$ & 1347.8 & 1954 & 1954 \\
\hline 60 & Xingtal & 53798 & $37^{\circ} 04^{\prime}$ & $114^{\circ} 30^{\prime}$ & 76.8 & 1954 & 1922 \\
\hline 61 & Yanan & 53845 & $36^{\circ} 36^{\prime}$ & $109^{\circ} 30^{\prime}$ & 957.6 & 1945 & 1952 \\
\hline 62 & Jicxiu & 5.3863 & $37^{\circ}() 3^{\prime}$ & $111^{\circ} 56^{\prime}$ & 748.8 & 1921 & 1921 \\
\hline 63 & Anyang & 5.3898 & $36^{\circ} 07^{\prime}$ & $114^{\circ} 22^{\prime}$ & 75.5 & 1932 & 1919 \\
\hline 64 & Pingllang & 53915 & $35^{\circ} 33^{\prime}$ & $106^{\circ} 40^{\prime}$ & 1.346 .6 & 19.37 & 1951 \\
\hline 6.5 & Qingyang Xlfengzhen & 5392.3 & $35^{\circ} 44^{\prime}$ & $107^{\circ} 38^{\prime}$ & 1421.9 & 1937 & 1951 \\
\hline 66 & Yuncheng & 53959 & $35^{\circ} 02^{\prime}$ & $111^{\circ} 01^{\prime}$ & 376.0 & 1939 & 1956 \\
\hline 67 & Jarud Qi & 54026 & $44^{\circ} 34^{\prime}$ & $120^{\circ} 54^{\prime}$ & 265.0 & 1953 & 1953 \\
\hline 68 & Bairin Zuoqi & 54027 & $43^{\circ} 59^{\prime}$ & $119^{\circ} 24^{\prime}$ & 484.4 & 1953 & 1953 \\
\hline 69 & Sulfente & $54(1) 96$ & $44^{\circ} 23^{\prime}$ & $131^{\circ}\left(09^{\prime}\right.$ & 496.7 & 19.36 & 1936 \\
\hline 70 & Abagnar Qi & 54102 & $43^{\circ} 57^{\prime}$ & $116^{\circ} 04^{\prime}$ & 989.5 & 1939 & 1953 \\
\hline 71 & $\operatorname{Lin} x i$ & 54115 & $43^{\circ} 36^{\prime}$ & $118^{\circ}\left(04^{\prime}\right.$ & $779 .()$ & 19.36 & 1936 \\
\hline 72 & Tongliao & 54135 & $43^{\circ} 36^{\prime}$ & $122^{\circ} 16^{\prime}$ & 178.5 & 1936 & 1936 \\
\hline 73 & Siping & 541.57 & $43^{\circ} 11^{\prime}$ & $124^{\circ} 20^{\prime}$ & 164.2 & 19,34 & 1934 \\
\hline 74 & Dunhua & 54185 & $43^{\circ} 22^{\prime}$ & $128^{\circ} 12^{\prime}$ & 52.3 .7 & 1931 & 1931 \\
\hline 75 & Duolun & 54208 & $42^{\circ} 11^{\prime}$ & $116^{\circ} 28^{\prime}$ & 124.4 .4 & 1938 & 1938 \\
\hline 76 & Chilfen & 54218 & $42^{\circ} 16^{\prime}$ & $118^{\circ} 58^{\prime}$ & 571.1 & 1936 & 1936 \\
\hline 77 & Fuxin & 542.37 & $42^{\circ}\left(02^{\prime}\right.$ & $121^{\circ} 39^{\prime}$ & 144.0 & 1938 & 1938 \\
\hline 78 & Yanji & 54292 & $42^{\circ} 53^{\prime}$ & $129^{\circ} 28^{\prime}$ & 176.8 & 1914 & 1914 \\
\hline 79 & Weichang & 54311 & $41^{\circ} 56^{\prime}$ & $117^{\circ} 45^{\prime}$ & 842.3 & 19.36 & 1936 \\
\hline 80 & Chaoyang & 54324 & $41^{\circ} 33^{\prime}$ & $120^{\circ} 27^{\prime}$ & 169.2 & 1932 & 1908 \\
\hline 81 & Jinzhou & 543.37 & $41^{\circ} 08^{\prime}$ & $121^{\circ} 07^{\prime}$ & 65.9 & 1939 & 1936 \\
\hline
\end{tabular}


Table 7. (continued)

\begin{tabular}{|c|c|c|c|c|c|c|c|}
\hline & \multirow[b]{2}{*}{ Stutlon name } & \multirow{2}{*}{$\begin{array}{l}\text { Stallon } \\
\text { number }\end{array}$} & \multirow[b]{2}{*}{ Lalllude" } & \multirow[b]{2}{*}{ Longltude" } & \multirow[b]{2}{*}{ Elevallour } & \multicolumn{2}{|c|}{$\begin{array}{l}\text { Filrsil year } \\
\text { of record } \\
\end{array}$} \\
\hline & & & & & & Temp. & Preclp. \\
\hline 82 & 'onghua & 54.36 .3 & $41^{\circ} 41^{\prime}$ & $125^{\circ} 54^{\prime}$ & $4(12,9$ & 1936 & 1936 \\
\hline 83 & Linflang & 54.374 & $41^{\circ} 4.3^{\prime}$ & $126^{\circ} 55^{\prime}$ & 3.32 .5 & 195.3 & 19.38 \\
\hline 84 & Zhunglakou & 54401 & $40^{\circ} 47^{\prime}$ & $114^{\circ} 53^{\prime}$ & 72.4 .2 & 19.37 & 1919 \\
\hline 8.5 & Chengue & 54423 & $4\left(0^{\circ} 58^{\prime}\right.$ & $117^{\circ} 56^{\prime}$ & 375.2 & 1937 & 1922 \\
\hline 86 & Xingchong & 54455 & 4()$^{\circ} 3.5^{\prime}$ & $120^{\circ} 42^{\prime}$ & 8.8 & 1936 & 19.36 \\
\hline 87 & Calxlan Xlongyue & 54476 & 4()$^{\circ} 10^{\prime}$ & $122^{\circ}\left(19^{\prime}\right.$ & 20.4 & 1914 & 1914 \\
\hline 88 & Kuanding & 5449.3 & $40^{\circ} 4.3^{\prime}$ & $124^{\circ} 47^{\prime}$ & 26() .1 & 1954 & 1936 \\
\hline 89 & Dandong & 54497 & 4()$^{n}() 3^{\prime}$ & $124^{\circ} 20^{\prime}$ & 15.1 & 1924 & 1907 \\
\hline 90 & Cangahou & 54616 & $38^{\circ} 20^{\prime}$ & $116^{\circ} 50^{\prime}$ & 9.6 & 1954 & 19.30 \\
\hline 91 & Dezhou & 54714 & $37^{\circ} 26^{\prime}$ & $116^{\circ} 19^{\prime}$ & 21.2 & 1951 & 1932 \\
\hline 92 & Huimin & 54725 & $37^{\circ} .30^{\prime}$ & $117^{\circ} 32^{\prime}$ & 11.3 & 19.3 .3 & 1929 \\
\hline 93 & Rongchengehenshanto & 54776 & $37^{\circ} 24^{\prime}$ & $122^{\circ} 41^{\prime}$ & 47.7 & 1924 & 1886 \\
\hline 94 & Wellang & 54843 & $36^{\circ} 42^{\prime}$ & $119^{\circ}\left(15^{\prime}\right.$ & 44.1 & 1929 & 1929 \\
\hline 95 & Lalyang & 54852 & $36^{\circ} 56^{\prime}$ & 12()$^{\circ} 42^{\prime}$ & $3(0.5$ & 19.30 & 1932 \\
\hline 96 & Here & 54916 & $35^{\circ} 15^{\prime}$ & $115^{\circ} 26^{\prime}$ & 49.7 & 19.33 & 19.31 \\
\hline 97 & Y'unzhou & 54916 & $35^{\circ} 34^{\prime}$ & $116^{\circ} 51^{\prime}$ & 51.6 & 1951 & 1951 \\
\hline 98 & Juxian: & 54936 & $35^{\circ} 35^{\prime}$ & $118^{\circ} 50^{\prime}$ & 107.4 & 19.31 & 1951 \\
\hline$y)$ & Linyl & 54938 & $35^{\circ} 03^{\prime}$ & $118^{\circ} 21^{\prime}$ & 87.9 & 1932 & 1929 \\
\hline $10(x)$ & Gecrshiquanhe & 5.5228 & $32^{\circ} 30^{\prime}$ & $80^{\circ} 05^{\prime}$ & 4728.0 & 1961 & 1961 \\
\hline 101 & Nagqu & $5 \$ 299$ & $31^{\circ} 29^{\prime}$ & $92^{\circ}\left(14^{\prime}\right.$ & 4507.0 & 1955 & 1955 \\
\hline 102 & Xlgaze & 55578 & $29^{\circ} 15^{\prime}$ & $88^{\circ} 53^{\prime}$ & $38.36 .1)$ & 1956 & 1956 \\
\hline 10.3 & Lhunze & 5.5696 & $28^{\circ} 25^{\prime}$ & $92^{\circ} 28^{\prime}$ & $3860.0 .1)$ & 1960 & 1960 \\
\hline 104 & Qumarleb & 56021 & $34^{\circ} 08^{\prime}$ & $95^{\circ} 47^{\prime}$ & 4175.0 & 1957 & 1957 \\
\hline 105 & Yushu & 56029 & $3.3^{\circ}\left(01^{\prime}\right.$ & $97^{\circ} 01^{\prime}$ & 3681.2 & 1954 & 19.54 \\
\hline 106 & Madol & $50,03,3$ & $34^{\circ} 55^{\prime}$ & $98^{\circ} 13^{\prime}$ & 4272.3 & 1953 & 195.3 \\
\hline 107 & Minxian & 50093 & $34^{\circ} 26^{\prime}$ & $104^{\circ} 01^{\prime}$ & 2314.6 & 19.37 & 1951 \\
\hline 108 & Wudu & 56096 & $33^{\circ} 24^{\prime}$ & $104^{\circ} 55^{\prime}$ & 1079.1 & 1944 & 1951 \\
\hline 109 & Qamdo & 561.37 & $31^{\circ}\left(09^{\prime}\right.$ & $97^{\circ} 10^{\prime}$ & $33(16.0$ & 1941 & 1952 \\
\hline 110 & Garze & 56146 & $31^{\circ} 37^{\prime}$ & $100^{\circ}(0) 0^{\prime}$ & 3393.5 & 1952 & 1951 \\
\hline 111 & Xiaojin & 56178 & $31^{\circ}(0)^{\prime}$ & $102^{\circ} 21^{\prime}$ & 2.369 .2 & 1952 & 1952 \\
\hline 112 & Songpan & 56182 & $32^{\circ} 39^{\prime}$ & $10.3^{\circ} 34^{\prime}$ & $28.5(0.7$ & 1940 & 1951 \\
\hline 11.3 & Pingwu & 56193 & $32^{\circ} 25^{\prime}$ & $104^{\circ} 31^{\prime}$ & 876.5 & 1937 & 1952 \\
\hline 114 & Mlanyang & 56196 & $31^{\circ} 28^{\prime}$ & $104^{\circ} 41^{\prime}$ & $47(0.8$ & 1954 & 1954 \\
\hline 115 & Litang & 56257 & $30)^{\circ}(x)^{\prime}$ & $1(x)^{\circ} 16^{\prime}$ & 3948.9 & 195.3 & 195.3 \\
\hline 116 & Yaan & 56287 & $2 y^{\circ} 59^{\prime}$ & $1(1) 3^{\circ}(x)^{\prime}$ & 627.6 & 19.39 & 1951 \\
\hline 117 & Nyingchi & 56,312 & $29^{\circ} 34^{\prime}$ & $94^{\circ} 28^{\prime}$ & $3(x)(x) .0$ & 1953 & 195.3 \\
\hline 118 & Leshan & 56.386 & $29^{\circ} .34^{\prime}$ & $1\left(13^{\circ} 45^{\prime}\right.$ & 424.2 & 1936 & 10.51 \\
\hline 119 & Jiulong & 56462 & $29^{\circ}(x)^{\prime}$ & $101^{\circ} 3()^{\prime}$ & 2987.3 & 1953 & 1953 \\
\hline 120 & leibo & 56485 & $28^{\circ} 16^{\prime}$ & $10.3^{\circ} 35^{\prime}$ & 1474.9 & 19.937 & 1954 \\
\hline 121 & Yibin & 56492 & $28^{\circ} 48^{\prime}$ & $104^{\circ} 36^{\prime}$ & .340 .8 & 19.32 & 19.51 \\
\hline
\end{tabular}


'Table 7. (continued)

\begin{tabular}{|c|c|c|c|c|c|c|c|}
\hline & \multirow[b]{2}{*}{ Statlon name } & \multirow{2}{*}{$\begin{array}{l}\text { Statlon } \\
\text { number }\end{array}$} & \multirow[b]{2}{*}{ Lalllude" } & \multirow[b]{2}{*}{ Longltucle" } & \multirow[b]{2}{*}{ Ëlevallon' } & \multicolumn{2}{|c|}{$\begin{array}{l}\text { Fist year } \\
\text { of record } \\
\end{array}$} \\
\hline & & & & & & 'T'ump. & Proclp. \\
\hline 122 & Liflung & 56651 & $26^{\circ} 52^{\prime}$ & 10()$^{\circ} 1.3^{\prime}$ & 2.39 .3 .2 & 194.3 & 1951 \\
\hline 123 & Hulli & 56677 & $26^{\circ} .39^{\prime}$ & $1\left(12^{\circ} 15^{\prime}\right.$ & 1787.1 & 1938 & 195,3 \\
\hline 124 & Welning & 56601 & $26^{\circ} 52^{\prime}$ & $104^{\circ} 17^{\prime}$ & 22.37 .5 & 19.37 & 1051 \\
\hline 125 & Dull & 56751 & $25^{\circ} 42^{\prime}$ & $1(x)^{\circ} 11^{\prime}$ & $119(1.5$ & 19.39 & 1951 \\
\hline 126 & Panxlan & 56793 & $25^{\circ} 47^{\prime}$ & $1(1) 4^{\circ} 37^{\prime}$ & 1527.1 & 1940 & 1951 \\
\hline 127 & Lincang & 56051 & $23^{\circ} 57^{\prime}$ & $1(x)^{\circ} 13^{\prime}$ & 146.3 .7 & 1954 & 195.3 \\
\hline 128 & Jlnghong & 56959 & $22^{\circ}(x)^{\prime}$ & $1(K)^{\circ} 48^{\prime}$ & 552.7 & 1954 & 1954 \\
\hline 12) & Puer Slmao & 56964 & $22^{\circ} 4\left(0^{\prime}\right.$ & $101^{\circ} 24^{\prime}$ & $1.3(1) 2.1$ & 1052 & 1952 \\
\hline 1311 & Mengril & 5698.5 & $2.3^{\circ} 23^{\prime}$ & $1(1) 3^{\circ} 2.3^{\prime}$ & $1.30(1.7$ & 1928 & 1951 \\
\hline 1.31 & Hokou & 56989 & $22^{\circ} 3()^{\prime}$ & $103^{\circ} 57^{\prime}$ & 1367.0 & 1954 & 1954 \\
\hline 132 & LushI & $57(1) 67$ & $34^{\circ}() 3^{\prime}$ & $111^{\circ}\left(02^{\prime}\right.$ & 568.8 & 1953 & 1953 \\
\hline 13.3 & Luoyung & 57073 & $34^{\circ} 40^{\prime}$ & $112^{\circ} 25^{\prime}$ & 154.5 & 1951 & 19.31 \\
\hline 134 & Nanyang & 57178 & $33^{\circ} \mathrm{O} 2^{\prime}$ & $112^{\circ} 35^{\prime}$ & 129.2 & 1934 & 19.32 \\
\hline 1.35 & Xihua & 57193 & $33^{\circ} 47^{\prime}$ & $114^{\circ} .31^{\prime}$ & 52.6 & 1954 & 19.54 \\
\hline 136 & Wanyuan & 572.37 & $32^{\circ} 04^{\prime}$ & $108^{\circ}() 2^{\prime}$ & 674.0 & 1953 & 1953 \\
\hline 137 & Ankang & 57245 & $32^{\circ} 43^{\prime}$ & $109^{\circ}\left(02^{\prime}\right.$ & 290.8 & 195.3 & 1953 \\
\hline 138 & Yunxian & 57253 & $32^{\circ} 51^{\prime}$ & $110^{\circ} 49^{\prime}$ & 201.9 & 1941 & 19.3 .3 \\
\hline 139 & Luohakou & .57265 & $32^{\circ} 23^{\prime}$ & $111^{\circ} 4()^{\prime}$ & $9(1,0$ & 1950 & 1933 \\
\hline 140 & Zhumadian & 57290 & $33^{\circ}(\mathrm{K})^{\prime}$ & $114^{\circ}() 1^{\prime}$ & 82.7 & 1953 & 1922 \\
\hline 141 & Xinyung & 57297 & $32^{\circ}\left(08^{\prime}\right.$ & $114^{\circ}\left(03^{\prime}\right.$ & 114.5 & 1932 & 1922 \\
\hline 142 & Bazhong & 57.313 & $31^{\circ} 51^{\prime}$ & $106^{\circ} 46^{\prime}$ & $36(1) .0$ & 195.3 & 1953 \\
\hline 143 & Zhongxiang & 57378 & $31^{\circ} 10^{\prime}$ & $112^{\circ} 34^{\prime}$ & 65.8 & 1953 & 1930 \\
\hline 144 & Sulning & 57405 & $3\left(0^{\circ} 30^{\prime}\right.$ & $105^{\circ} .35^{\prime}$ & 278.2 & 1936 & 1951 \\
\hline 145 & Nanchong & 57411 & $30^{\circ} 48^{\prime}$ & $106^{\circ}\left(15^{\prime}\right.$ & 297,7 & 1940 & 1952 \\
\hline 146 & Enshi & 57447 & 3()$^{\circ} 17^{\prime}$ & $109^{\circ} 28^{\prime}$ & 457.1 & 1951 & 19.3 .3 \\
\hline 147 & Jingzhou & 57476 & $30^{\circ} 20^{\prime}$ & $112^{\circ} 11^{\prime}$ & 32.6 & 1907 & $19) 6$ \\
\hline 148 & Neiflang & $575(1) 4$ & $29^{\circ} .35^{\prime}$ & $105^{\circ} 03^{\prime}$ & 347.1 & 19.36 & 1951 \\
\hline 149 & Pengshul & 57537 & $29^{\circ} 18^{\prime}$ & $108^{\circ} 10^{\prime}$ & 310,6 & 1937 & 1951 \\
\hline 150 & Yucyang & 57584 & $29^{\circ} 2.3^{\prime}$ & $113^{\circ}\left(05^{\prime}\right.$ & 51.6 & 1924 & 1053 \\
\hline 151 & 'Tongz.1 & 576016 & $28^{\circ} 08^{\prime}$ & $105^{\circ} 5()^{\prime}$ & 972.0 & 19.37 & 1951 \\
\hline 152 & Youyang & 576,33 & $28^{\circ} .50^{\prime}$ & $108^{\circ} 46^{\prime}$ & 66.3 .7 & 1938 & 1951 \\
\hline 15.3 & Yuanling & 5765.5 & $28^{\circ} 28^{\prime}$ & 11()$^{\circ} 24^{\prime}$ & 151,6 & $19+2$ & 1953 \\
\hline 154 & Changele & 57662 & $29^{\circ}\left(13^{\prime}\right.$ & $111^{\circ} 41^{\prime}$ & 35.0 & 1932 & 1951 \\
\hline 15.5 & Zunyi & 57713 & $27^{\circ} 42^{\prime}$ & $106^{\circ} 53^{\prime}$ & 84.3 .9 & 1941 & 1951 \\
\hline 156 & Meitan & 57722 & $27^{\circ} 46^{\prime}$ & $1(1) 7^{\circ} 28^{\prime}$ & 791.8 & 1940 & 1951 \\
\hline 157 & Sinan & 57731 & $27^{\circ} 57^{\prime}$ & $108^{\circ} 15^{\prime}$ & 416.3 & 1940 & 1951 \\
\hline 1.58 & Shaoyung & 57766 & $27^{\circ} 14^{\prime}$ & $111^{\circ} 28^{\prime}$ & 248.6 & 19.36 & 1951 \\
\hline 1.59 & Yichun & 57793 & $27^{\circ} 48^{\prime}$ & $114^{\circ} 23^{\prime}$ & 1.31 .3 & 195.3 & 1953 \\
\hline 160 & Jian & 57799 & $27^{\circ}\left(07^{\prime}\right.$ & $114^{\circ} .58^{\prime}$ & 76.4 & 1930 & 19.30) \\
\hline 161 & Wugang & 5785.3 & $26^{\circ} 44^{\prime}$ & $11\left(0^{\circ} 38^{\prime}\right.$ & 341.0 & 19.5 .3 & 195.3 \\
\hline
\end{tabular}


Tuble 7. (continued)

\begin{tabular}{|c|c|c|c|c|c|c|c|}
\hline & \multirow[b]{2}{*}{ Station name } & \multirow{2}{*}{$\begin{array}{l}\text { Stution } \\
\text { number }\end{array}$} & \multirow[b]{2}{*}{ Latllude" } & \multirow[b]{2}{*}{ Longltude" } & \multirow[b]{2}{*}{ Elevalton } & \multicolumn{2}{|c|}{$\begin{array}{l}\text { Flrst year } \\
\text { of record }\end{array}$} \\
\hline & & & & & & Tomp. & Preclp \\
\hline 162 & L.lugling & 57866 & $26^{\circ} 14^{\prime}$ & $111^{\circ} 37^{\prime}$ & 172.6 & 1942 & 11 \\
\hline 16.3 & Hengyang & 57872 & $266^{\prime \prime} 54^{\prime}$ & $112^{\circ} 36^{\prime}$ & 10.3 .2 & 19.32 & 10,1 \\
\hline 164 & Suchang & 57896 & $26^{\circ} 2()^{\prime}$ & $114^{\circ} 3()^{\prime}$ & 126.1 & 1951 & 19.51 \\
\hline 16.5 & Xingren & $579(1) 2$ & $25^{\circ} 26^{\prime}$ & $105^{\circ} 11^{\prime}$ & 1.378 .5 & 1943 & 1951 \\
\hline 166 & Lucodlan & 57916 & $25^{\circ} 26^{\prime}$ & $106^{\circ} 46^{\prime}$ & $44(0) .3$ & 1944 & 1952 \\
\hline 167 & Gullin & 57957 & $25^{\circ} 20^{\prime}$ & $110^{\circ} 18^{\prime}$ & 161.8 & 1935 & 19.51 \\
\hline 168 & Chenahou & 57972 & $25^{\circ} 48^{\prime}$ & $113^{\circ}\left(12^{\prime}\right.$ & 184,9 & 19.36 & 1957 \\
\hline 16) & Ganzhou & $57(99.3$ & $25^{\circ} .51^{\prime}$ & $114^{\circ} .57^{\prime}$ & 12.3 .8 & 1939 & 1924 \\
\hline 17() & Hacixian & 58102 & $.3 .3^{\circ} 52^{\prime}$ & $115^{\circ} 46^{\prime}$ & 37.7 & 1953 & 1922 \\
\hline 171 & Sheyang & 581.50 & $33^{\circ} 46^{\prime}$ & $12.0^{\circ} 15^{\prime}$ & 2.0 & 1954 & 195.3 \\
\hline 172 & fluyung & $582(0) 3$ & $32^{\circ} 55^{\prime}$ & $115^{\circ} 4 y^{\prime}$ & $3(1), 6$ & 1953 & 1922 \\
\hline 17.3 & Bengfu & 58221 & $32^{\circ} 57^{\prime}$ & $117^{\circ} 23^{\prime}$ & 18.7 & 19.32 & 1918 \\
\hline 174 & Donglai & 58251 & $32^{\circ} .51^{\prime}$ & $120^{\circ} 19^{\prime}$ & 4,3 & 1924 & 1924 \\
\hline 175 & Nantong & 58259 & $32^{\circ}() 1^{\prime}$ & $120^{\circ} 51^{\prime}$ & 5.3 & 1917 & 1917 \\
\hline 176 & Huoshan & .58314 & $31^{\circ} 24^{\prime}$ & $116^{\circ} 19^{\prime}$ & 68.1 & 1954 & 1954 \\
\hline 177 & Hoful & 58.321 & $31^{\circ} 52^{\prime}$ & $117^{\circ} 14^{\prime}$ & 27.9 & 1946 & 1952 \\
\hline 178 & Wuhu & 58.3 .34 & $31^{\circ} 20^{\prime}$ & $118^{\circ} 23^{\prime}$ & 14.8 & 1924 & 1880 \\
\hline 179 & Huangshi & 58407 & .3()$^{\circ} 15^{\prime}$ & $115^{\circ}(1) 3^{\prime}$ & 19.6 & 1954 & 19,34 \\
\hline 180 & Dinghal & 58477 & 3()$^{\circ}() 2^{\prime}$ & $122^{\circ}() 7^{\prime}$ & 35.7 & 1933 & 1931 \\
\hline 181 & Jlujlang & $585(12$ & $29^{\circ} 44^{\prime}$ & $\left.116^{\circ}()\right)^{\prime}$ & 33,2 & 1924 & 1885 \\
\hline 182 & Tunxi & 58.3 .31 & $2 y^{\circ} \cdot 6.3^{\prime}$ & $118^{\circ} 17^{\prime}$ & 145,4 & 1953 & 195.3 \\
\hline 18.3 & Shengxlan & 585.56 & $2 y^{\circ} .36^{\prime}$ & 12()$^{\circ} 49^{\prime}$ & $1(1) 4.3$ & 19.3 .3 & 1929 \\
\hline 184 & LI Shui & 58646 & $28^{\circ} 27^{\prime}$ & $110^{\circ} 55^{\prime}$ & 60.8 & 19.33 & 19.32 \\
\hline 185 & Huangyan & 58606.5 & $28^{\circ} .38^{\prime}$ & $121^{\circ} 25^{\prime}$ & 1.3 & 1951 & 19,32 \\
\hline 186 & Pucheng & 58731 & $27^{\circ} .55^{\prime}$ & $118^{\circ} .32^{\prime}$ & 276.9 & 193.5 & 1936 \\
\hline 187 & Jiunyang & 587.34 & $27^{\circ} 2()^{\prime}$ & $118^{\circ} 07^{\prime}$ & 181.1 & 194() & $1940)$ \\
\hline 188 & Fudling & 58754 & $27^{\circ} 20^{\prime}$ & 12()$^{\circ} 12^{\prime}$ & 36.2 & 1953 & 1953 \\
\hline 180 & Gilangchang & 5881.3 & $26^{\circ} 51^{\prime}$ & $116^{\circ} 20^{\prime}$ & $14,3,8$ & 1954 & 1954 \\
\hline 19() & Nanping & 588.34 & $26^{\circ} .30^{\prime}$ & $118^{\circ} 10^{\prime}$ & 125,6 & 193.35 & 1935 \\
\hline 191 & Duhua Jluxianshan & 589.31 & $25^{\circ} 43^{\prime}$ & $118^{\circ}\left(16^{\prime}\right.$ & 165.3 .5 & 1956 & 1956 \\
\hline 192 & Cisangman & 59()$(17$ & $24^{\circ} 42^{\prime}$ & $1\left(155^{\circ}() 4^{\prime}\right.$ & 1249.6 & 19.54 & 1954 \\
\hline 193 & Llanxian & $59(172$ & $24^{\circ} 47^{\prime}$ & $112^{\circ} 23^{\prime}$ & 97.6 & 19.52 & 1953 \\
\hline 194 & Shanguan & $59(182$ & $24^{\circ} 48^{\prime}$ & $113^{\circ} .35^{\prime}$ & $69) .3$ & 1946 & 1951 \\
\hline 195 & Meixian & 59117 & $24^{\circ} 16^{\prime}$ & $116^{\circ}() 6^{\prime}$ & 87.8 & 195.3 & 1953 \\
\hline 196 & Zhang:hou & 59126 & $2 \cdot 4^{0} .3()^{\prime}$ & $117^{\circ} .39^{\prime}$ & 28.9 & 1951 & 1941 \\
\hline 197 & Busce & 59211 & $2.3^{\circ} 54^{\prime}$ & $106^{\circ} .36^{\prime}$ & 173.5 & 19.39) & 1951 \\
\hline 198 & Gulping & 50254 & $2.3^{\circ} 24^{\prime}$ & $11(1)^{\circ}\left(1.5^{\prime}\right.$ & 42.2 & 195.3 & 195.3 \\
\hline 199 & Hcyiman & 54293 & $23^{\circ} 44^{\prime}$ & $114^{\circ} 41^{\prime}$ & 41.1 & 195.3 & 1953 \\
\hline $2(k)$ & Longzhou & 59417 & $22^{n} 22^{\prime}$ & $1\left(16^{\circ} 45^{\prime}\right.$ & 128.3 & 1953 & 195.3 \\
\hline 2.111 & Yulin & $5 \% 4.53$ & $22^{\circ} .38^{\prime}$ & $110^{\circ} 10^{\prime}$ & 81.8 & 1954 & 1954 \\
\hline
\end{tabular}


Table 7. (conlinued)

\begin{tabular}{|c|c|c|c|c|c|c|c|}
\hline & \multirow[b]{2}{*}{ Stution name } & \multirow{2}{*}{$\begin{array}{l}\text { Station } \\
\text { number }\end{array}$} & \multirow[b]{2}{*}{ Lalltude } & \multirow[b]{2}{*}{ Longltude } & \multirow[b]{2}{*}{ Elevatlonc } & \multicolumn{2}{|c|}{$\begin{array}{l}\text { First year } \\
\text { of racord }\end{array}$} \\
\hline & & & & & & Temp. & Precip. \\
\hline 202 & Shenzhen & 59493 & $22^{\circ} 33^{\prime}$ & $114^{\circ} 06^{\prime}$ & 18.2 & 1953 & 1953 \\
\hline 2() 3 & Halfen Shanwel & 59501 & $22^{\circ} 47^{\prime}$ & $115^{\circ} 22^{\prime}$ & 4.6 & 1953 & 1953 \\
\hline 204 & Danxian & 59845 & $19^{\circ} 31^{\prime}$ & $109^{\circ} 35^{\prime}$ & 168.7 & 1953 & 1953 \\
\hline $2(1) 5$ & Qlonghal & 59855 & $19^{\circ} 14^{\prime}$ & $110^{\circ} 28^{\prime}$ & 24.0 & 1953 & 1953 \\
\hline
\end{tabular}

"North

"East

- Melers above sea level 


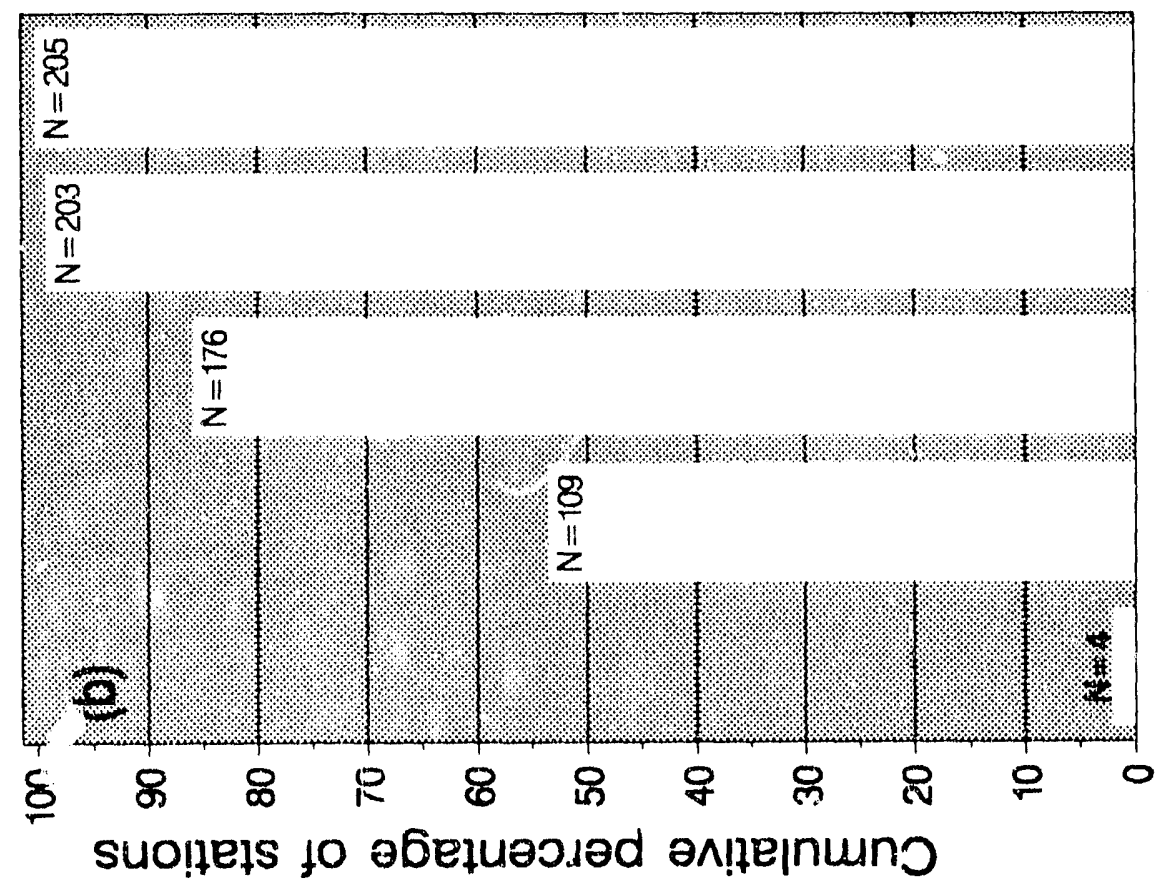

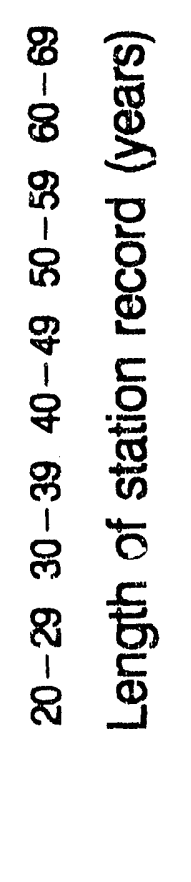

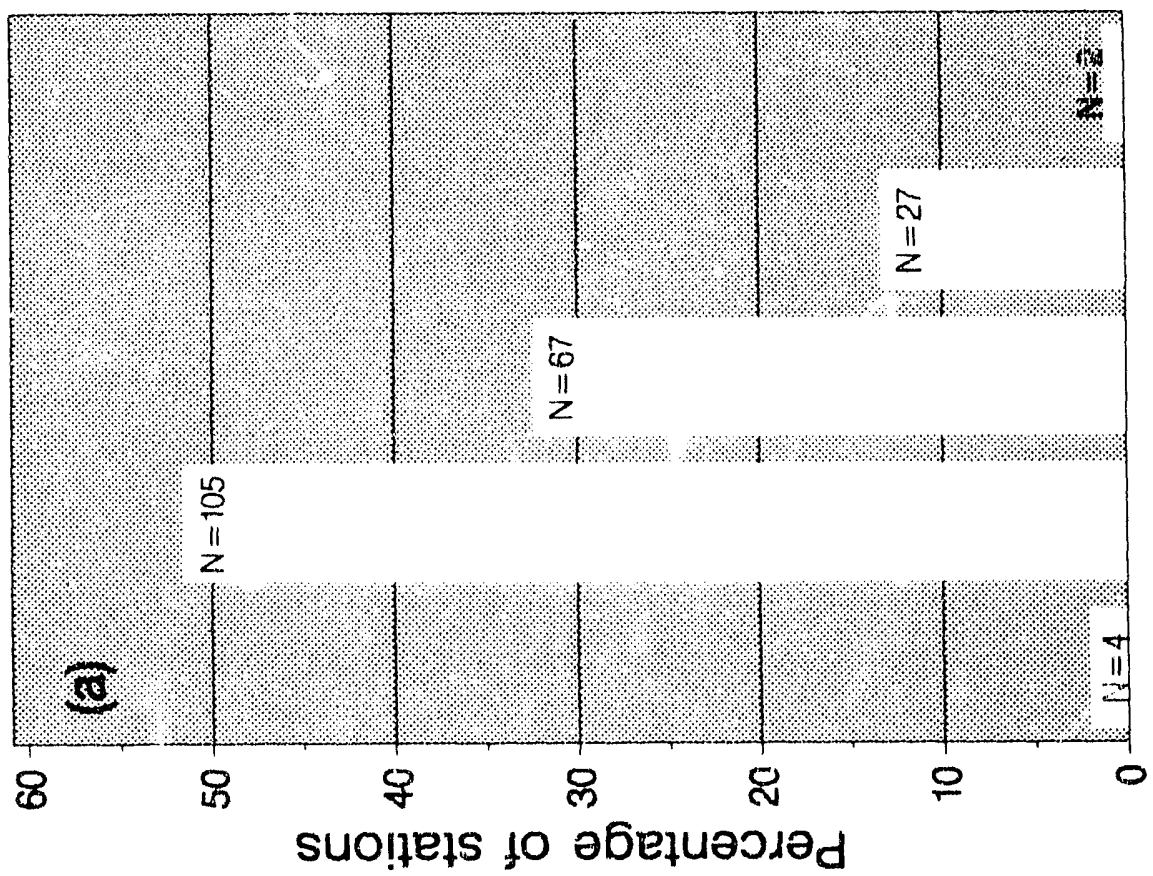

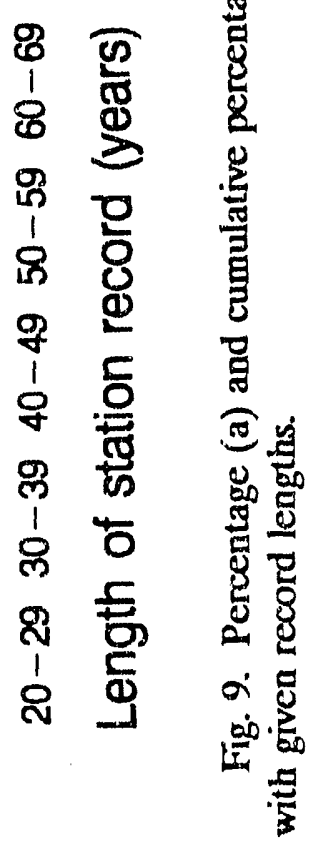



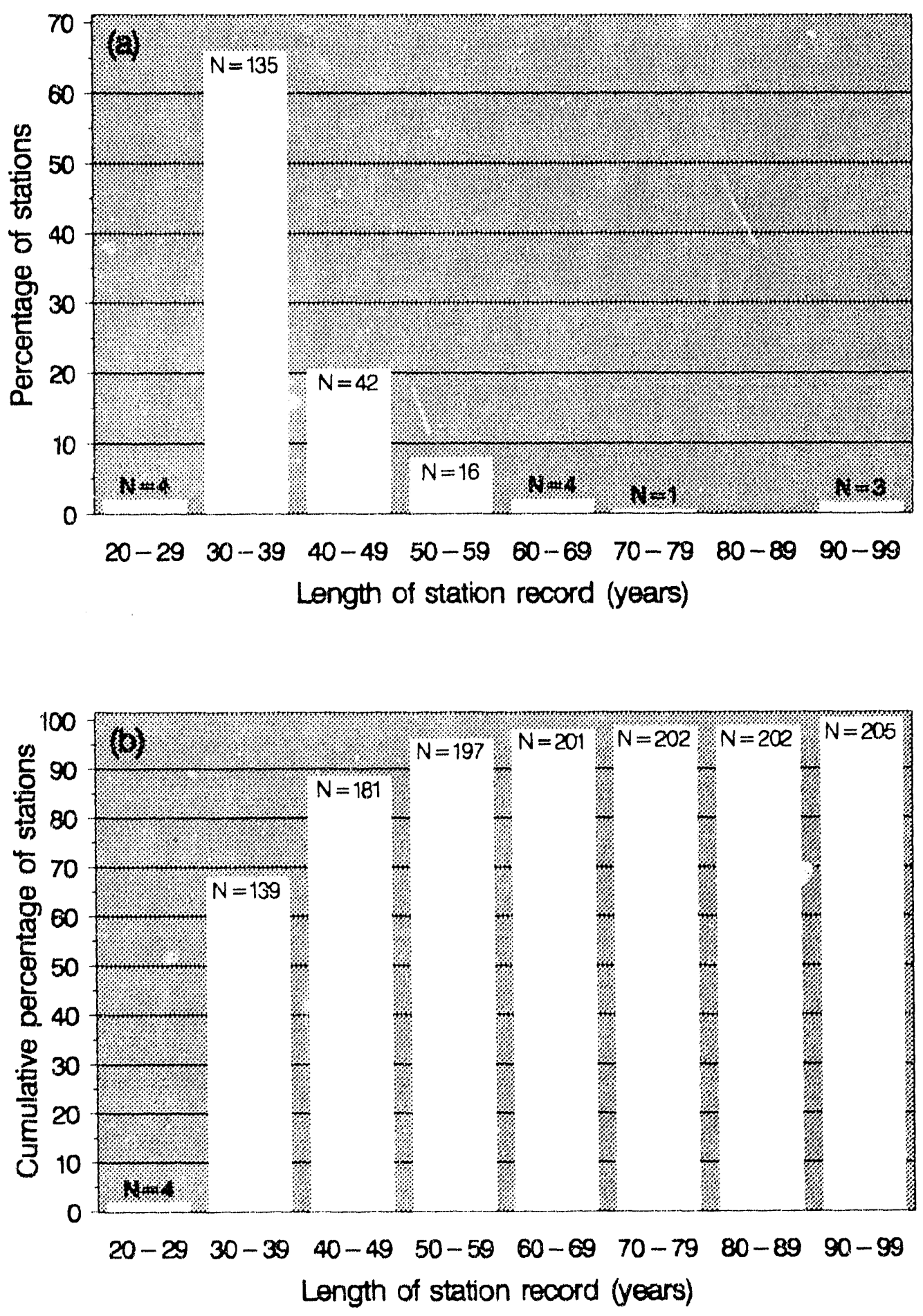

Fig. 10. Pcrcentage (a) and cumulative percentage (b) of stations from the PRC 205-station precipitation data set with given record lengths. 


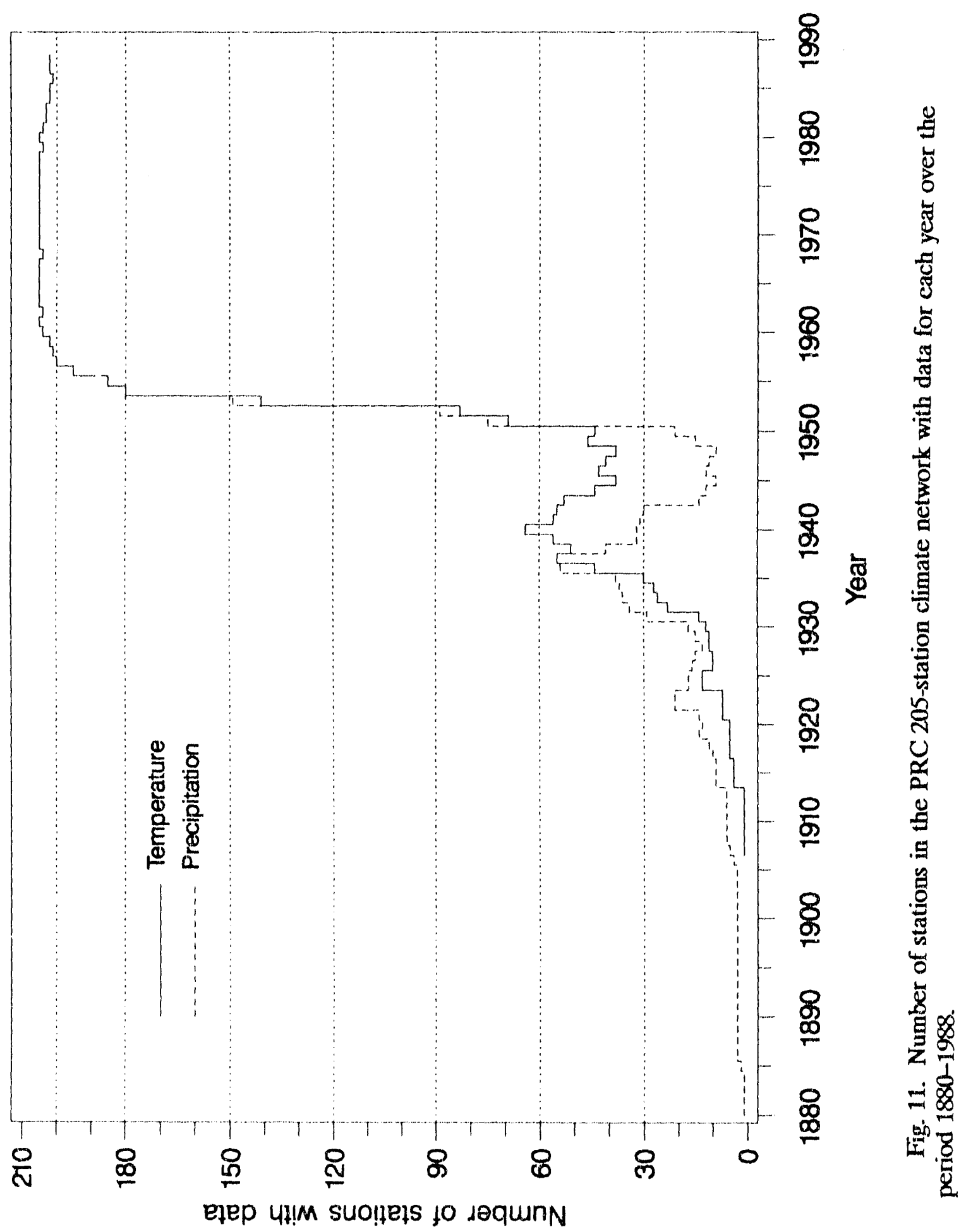




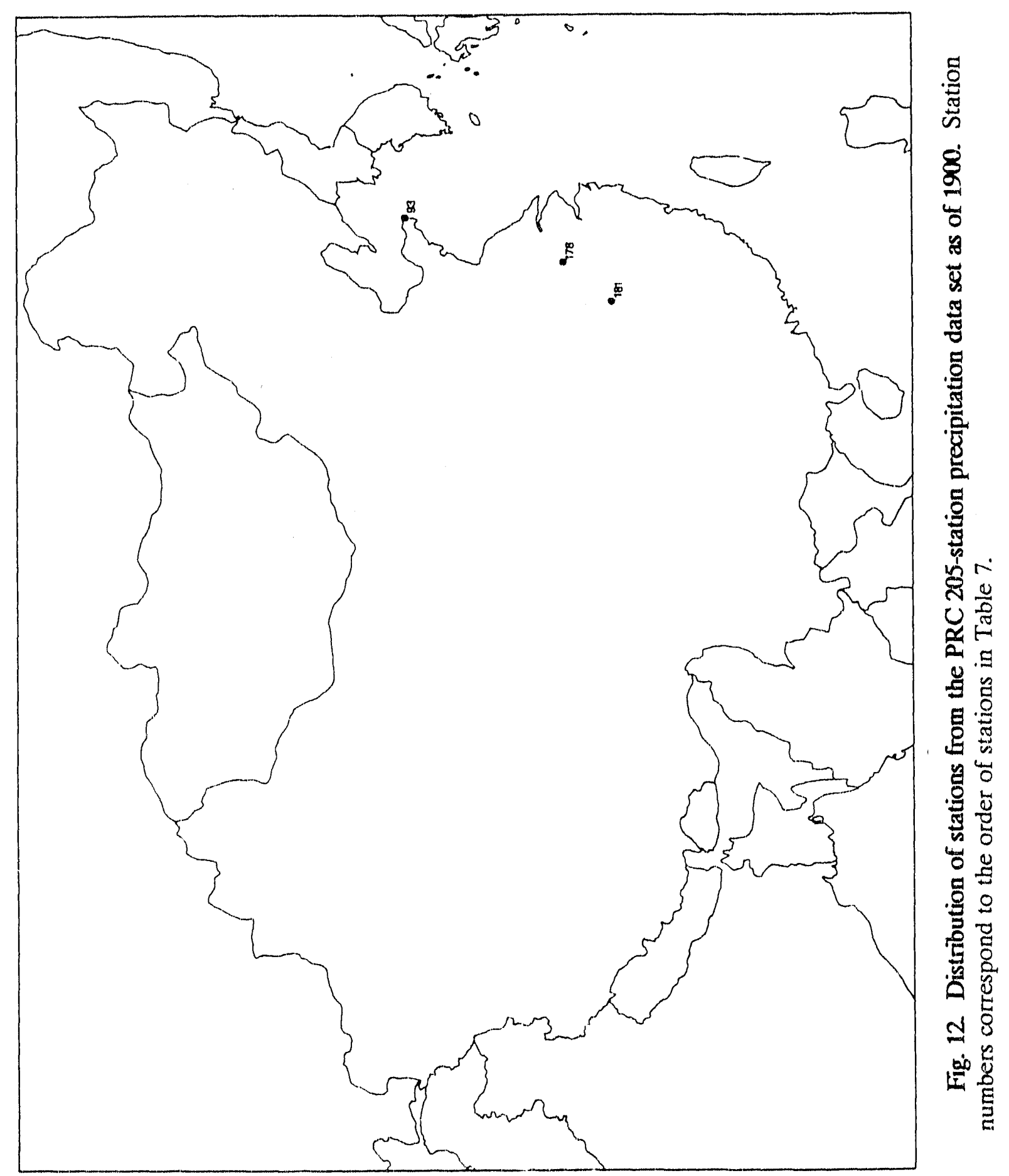




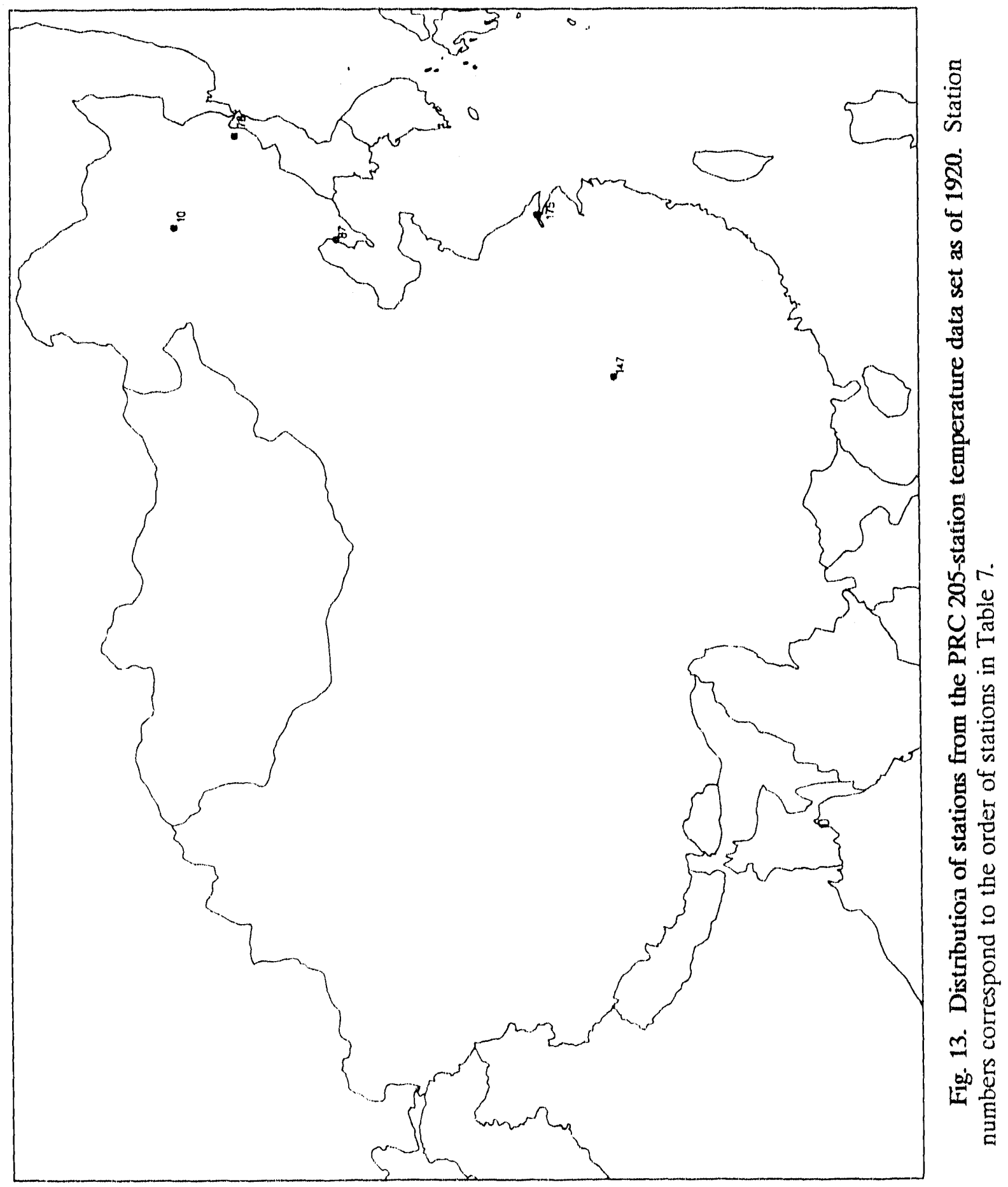




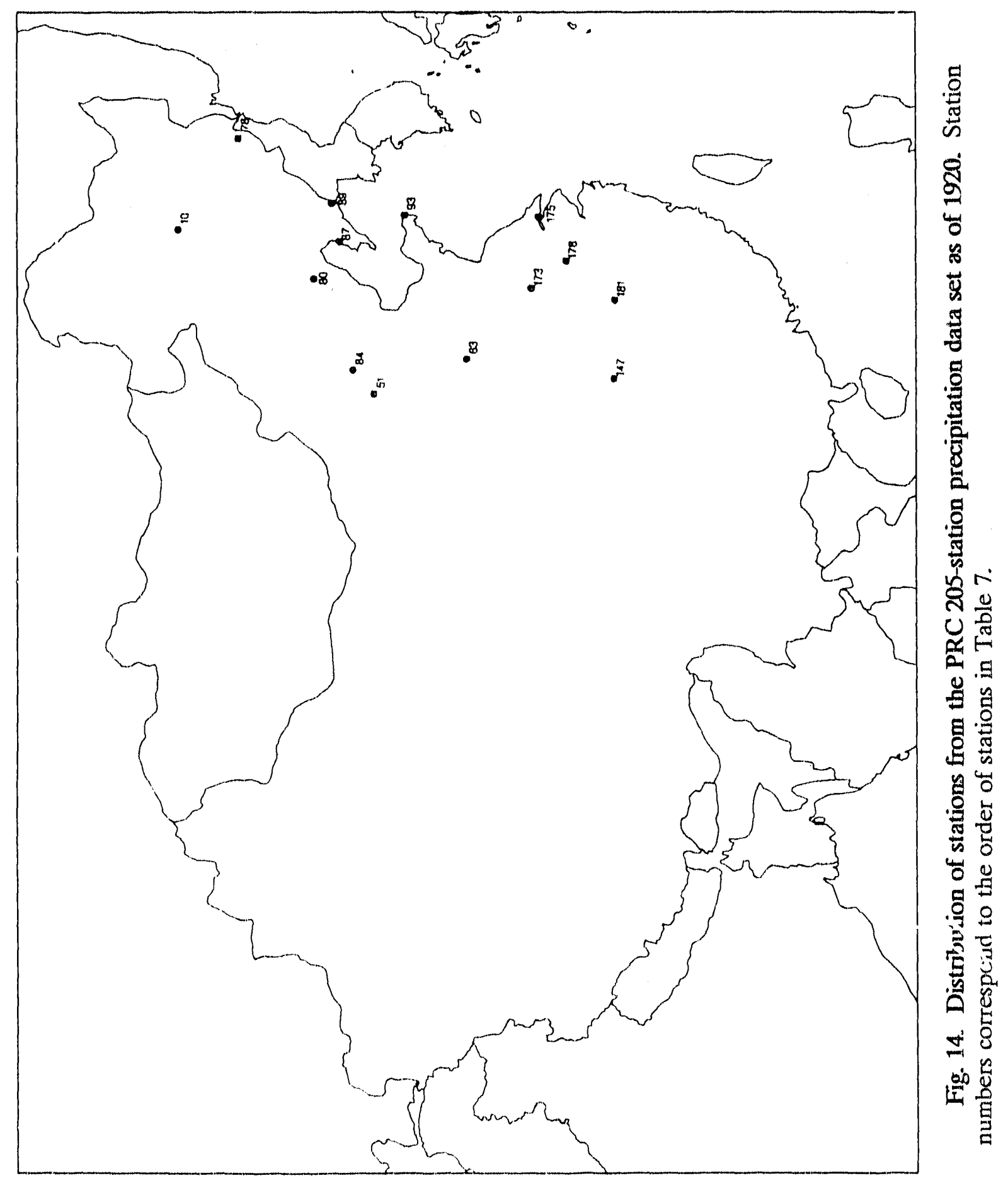




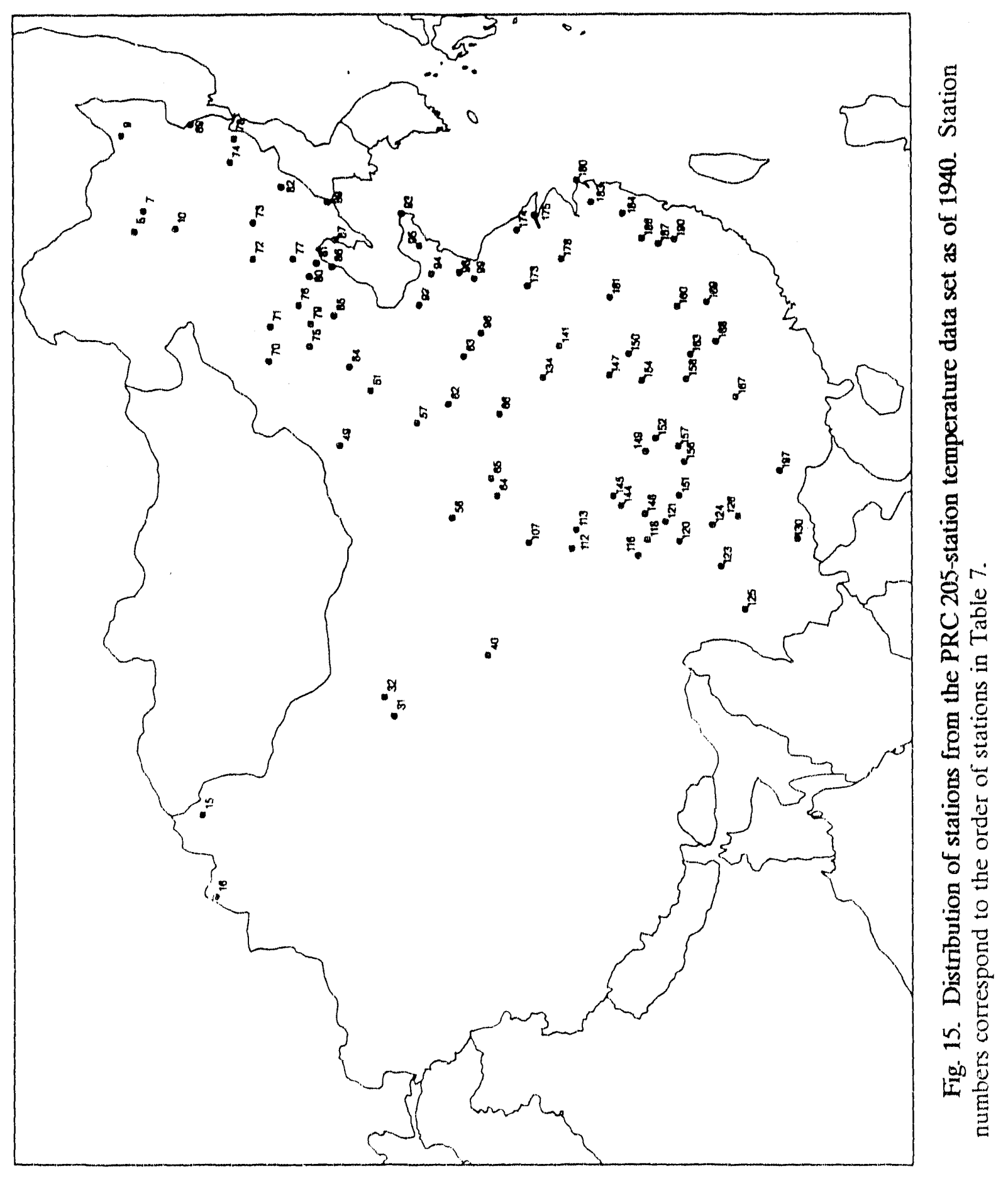




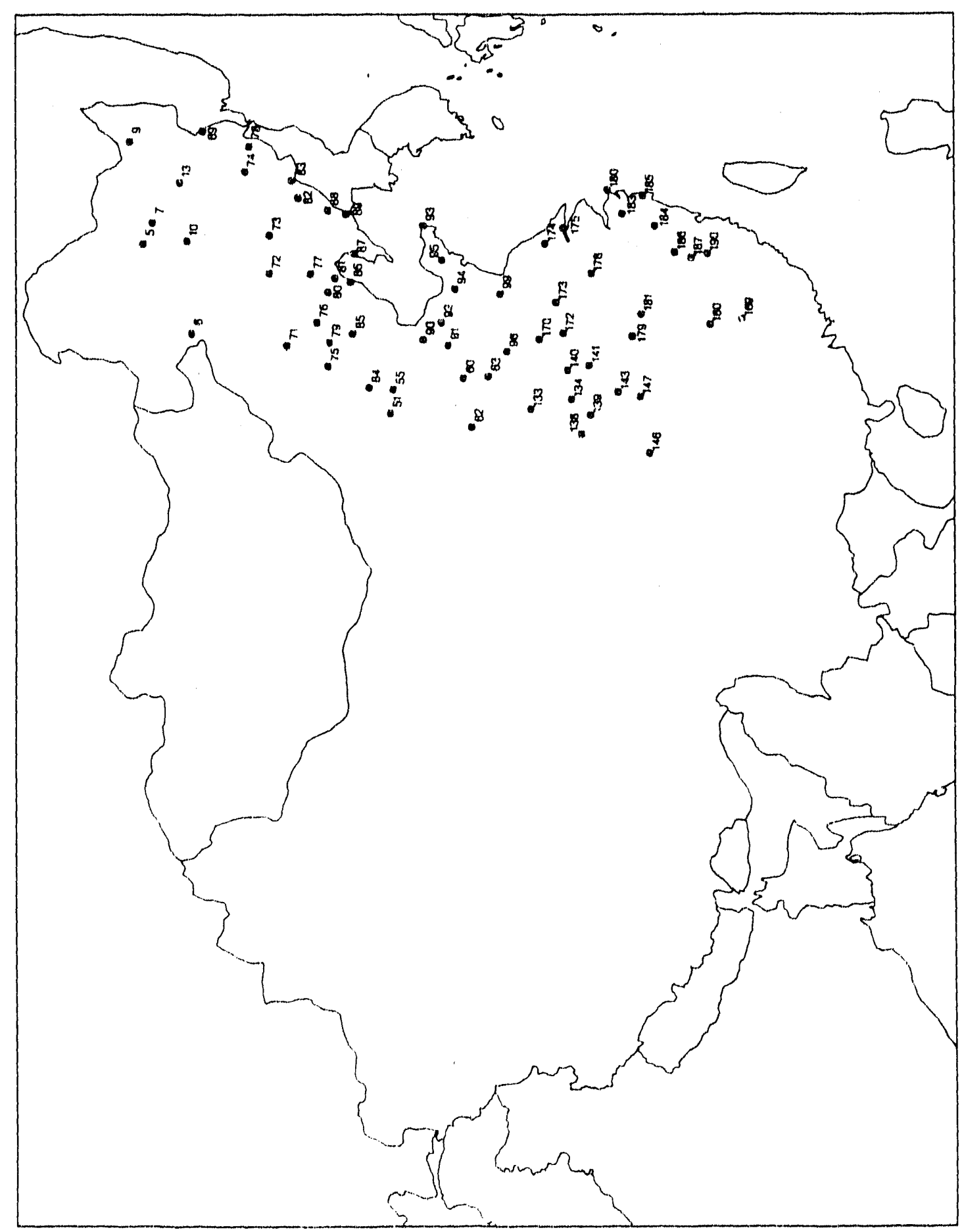

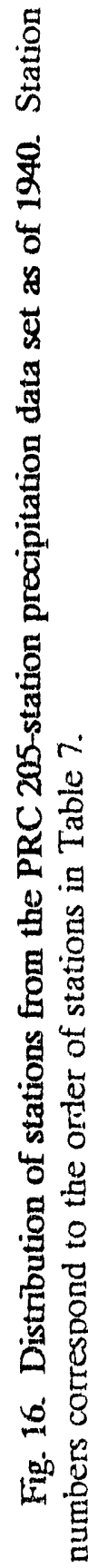


38

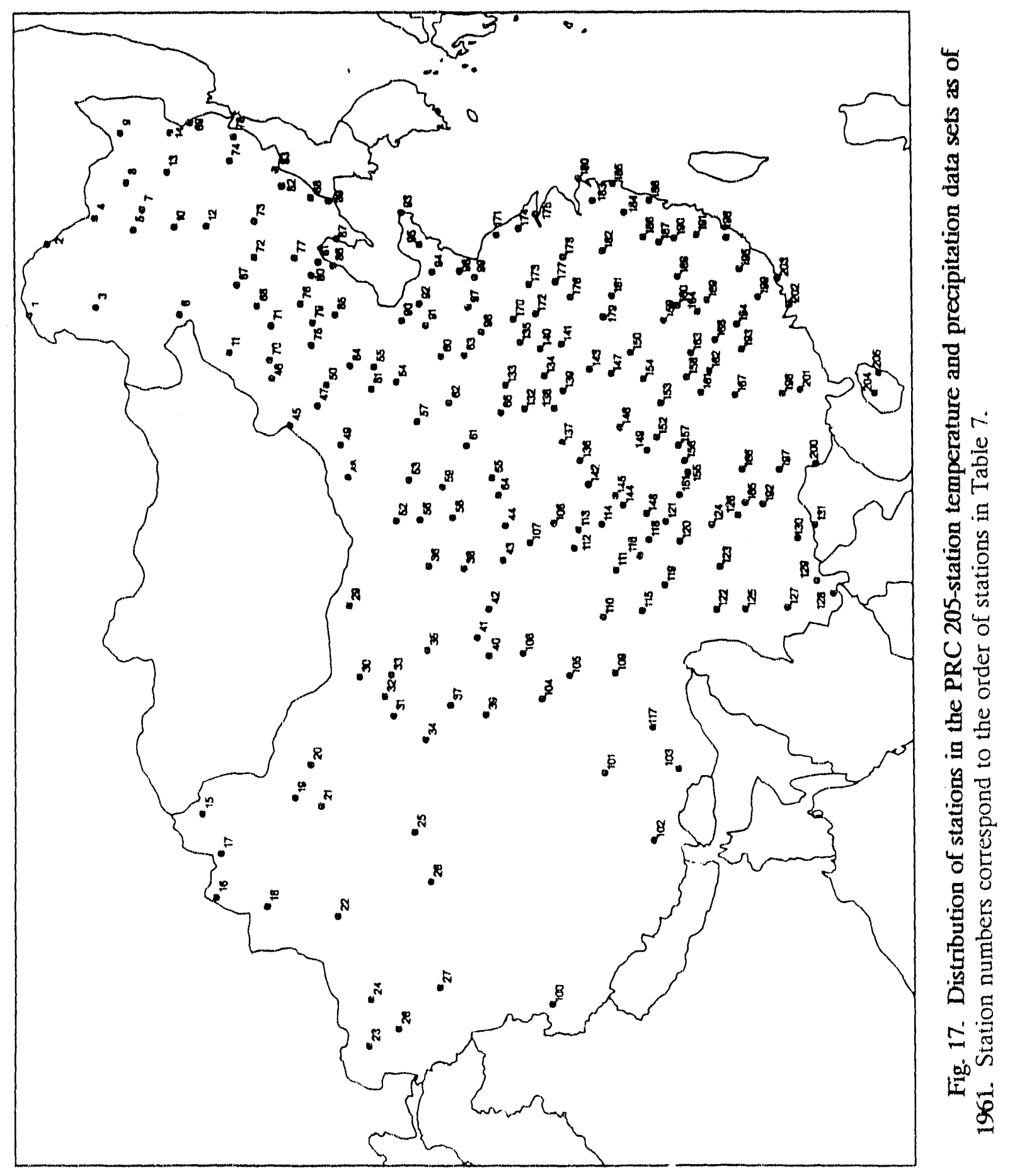




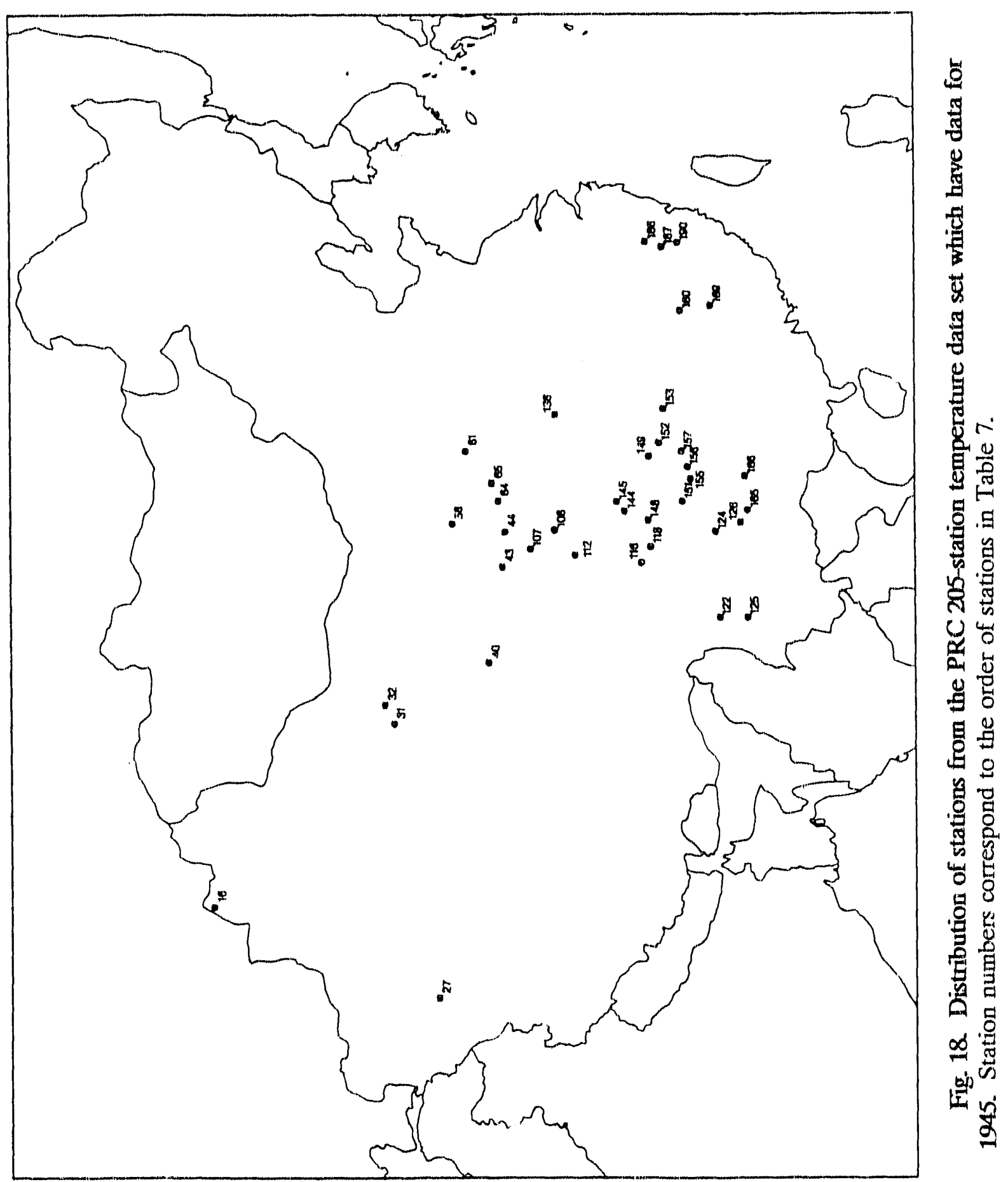


40

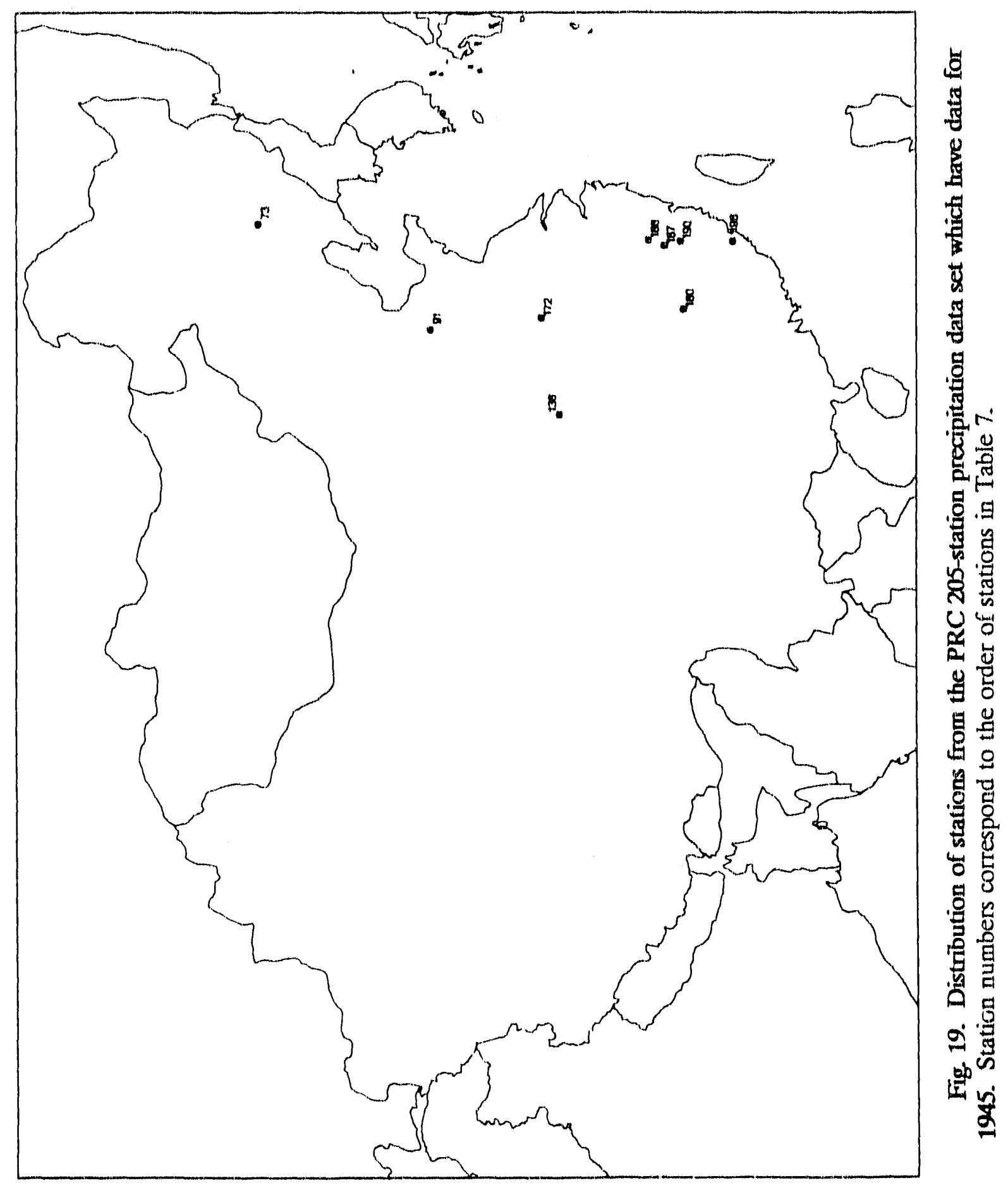




\section{APPLICATIONS OH'THE DAT'A}

Together these dila bases represent the mest comprehenslve, fong-lerm lnstrumental climale data presently available from the PRC. 'They may be used fin detecting and

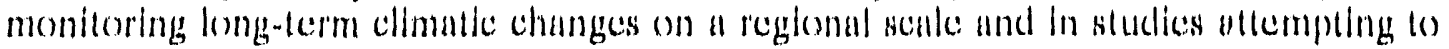
determine the climatic Impacts of urbanlantion and increased almospherite concentrations ol' grecnlouse gases. The data may also be used by dendrochronologlsts und paleocolimatologists for colibrating tree ring growth, pollen, and marline plankton data or by thesse studying impacts of periodice events such as voleanice cruptions or the Ei Nino/Southern Oscillation (ENSO). Exumples of the latlor Include the telesommuntention studies of Dibe and fu (1987), who exumined the correlalion between Yanglee River Valley summer prectplatilon and the ENSO, and Zhang of al. (1987) who analyed correlations between tropical sea surface temperalure und surfiec land temperatures in Chinu.

The potential uses of the 60)-station data set are especially myriad, owing to the many types of relatively long-term data. The temperature, precipitation, sun, cloud, and sonew cover diata should be especially useful in establishing relationships between reglonal and large-scalce ellmates.

Analyses of surfuce pressure and wind ficlds can play fmportant roles in examining spatial, temporal, and intensity variations of important seasonal climale features alfecting China such as the Siberian High and the monsoons of south, southeast, and cast Asia. Temperature, precipitalion, and relative humidity data should also be valuable in studying these mensoon circulations.

Sunshine duration and cloud amount data are useful in identifying patterns of spatial and temporal variability in each and in understanding past climatic conditions. Karl and Siteurer $(19)(0)$ have illustrated the importance of changes in regional eloudiness to temperature changes and show that increases in cloud amount over the United States since the mid-195(s may help explain its lower rate of temperature increase compared to the rest of the northern hemisphere and the observed decrease in the U.S, average daily temperature range. Sunshine duration measurements are also useful for examining the availatbility of surshine and can be used indirectly to determine average insolation. Cloud amount data, when coupled with other cloud parameters, are also useful in verifying and tunirg radiative-transfer schemes in climate models.

Monthly data on the number of days with snow cover can be used for studying regional feedhacks between snow cover extent and variables such as temperature, cloud cover, and relative humidity. They could also be used in conjunction with these and other variables to examine the temporal inlluene of late winter and early spring snow cover extent on the onset of the Aslan summer monsoon circulations.

\section{LIMITA'TIONS AND RESTRICIIONS}

Few station records included in the PRC data sets can be considered truly homogeneous. Even the best stations were subject to minor relocations or changes in observing times, and many have undoubtedly had the effects of urbanization imparted on measures of variables such as temperature (and therefore perhaps number of days with snow cover). Fortunalely, for the 6()-station notwork, detailed station historics are available to assist in proper interpretation of trends or jumps in the data. However, examination of these data has uncovered evidence of thres undocumenced station moves 
(Sects. 8 and 12). Users should thorelore exeredse cinulion when using the dala. Unlortunately, stalion histories for the 2015 -station netwerk are not presendly avaliable. la the interest of imely disseminalion of the data, all of the questionable values f'ound in the data have not been ressarched. Many have been l'nggged (Sects. 8 and 12) so that the user may cletermine how to trent them.

Inhomogencilles may have been crented in the sunshino and cloud anount diata through the evolution of sunshine recorder tnstrumentallon and cloud measurement procedures, Untortunately, little documentation is avallable al this time to contlim exact dales of sunshine recorder changes or glec details on methods employed by Chiness: observers In their estimution of cloud amount.

\section{QUALIT'Y ASSURANCE OF THE PRC CLIMATE DA'TA BASES}

An important part of the numerle clata package proesss at CDIAC is the qually assuranec (QA) of data before distribution. Data recelved at CDIAC are rarely in pertect condition lior immediate distribution, regardless of the source. To guarantec data of the highest possible quality, CDIAC conducts extensive QA reviews, which involve examining the dula for completeness, reasonableness, and accuracy. Although these reviews have common objectlves, they are tailored to ench data set, often regulding extensive programming elforts. Although timseconsuming, the QA process is an important component in the value-added concept of assuring aceurate, usable data for resentehers.

Given the large amount and many types of data contained in the PRC data sets as a whole, it is not surprising that CDIAC has found some crroncous and inconsistent values in the dala files. Many of these problems were resolved with the help of CAS, but in the interest of timely dissemination of the data, any semaining questionable data are llagged so users may treal these data as they sec lit. Flag codes for the data and their definitions are provided in Sect. 12. Descriptions ol the QA reviews performed for each of the PRC data sets are presented in the following sections.

\section{6()-SIATTION NETWORK}

The data from these stations were provided by CAS as two files; one with data extending through 1983, the other with data over the period 1984-1988. The latter data set, in addition to the twelve variables found in the former (Sects. 5 and 12), contained values of monthly extreme maximum and minimum temperature. These two data sets were interleaved aceording to station number, and the missing indicator "-9999" was inserted in the record position of extreme maximum and minimum temperature for years through 1983. The resulting data set was then examined thoroughly using computer solfware routines developed to check lor (1) trends or jumps in the data not explained by seasonal bycles or documented station moves; (2) statistical oulliers; (3) identical, non-zero values reported over consecutive months for vartables such is total precipitation and sunshine duration; (4) proper relationships between monthly temperature variables; and (5) impossible values (e.g., number of days with snow cover exceding the number of days in a particular month). The results of the QA checks (by data type), along with a brief assessment of station histories for the 6() stations, are given in the following sections. 


\section{Station Historics}

These histories (Appondle B) contaln much of the linformulion needed to determine If a partlcular station's data can be used conltdently by researchers in thelr assessments of reglonal and/or large-senle cllmate change, References fo data sources (Appendix C) are provided, as is information regarding statlon loculions (c,g, clly, suburb, or countryside, and elevilion), stulton moves, and observing llmes. However, some potentially useful station-specllic details are not present, For example, the switch from the Jordan Photographie Sunshine recorder to the Camphell-Stokes Sunsuine recorder, noted in Appendix $A$ as oceurering in 1954, may not have taken place at all stations simultaneously as implled. Sunshine recorder changes toek many years $t o$ Implement over the entlre U.S. surnshine recordling network (Steurer and Karl 1991).

Users should be aware that historles for all statlons extend only through 1983. Updates will hopefully be available at'a future dale. . . " was found that for three stations $(5.346 .3,58367$, and 5863.3$)$, the data record begins belore the perfecd deceumented by the station history. For three other stallons $(50745,54527$, and 56294), data is not avaldable until scveral years after the lirst year documented in the station histories. Finally, barometric pressure data suggest that three station historics (for stations 57127, 57461, and 57516) lack documentation of station moves (dliscussed in the following section).

\section{Monthly Mean Barometric Pressure}

The data seem to show an occasional departure from reporting values to the nearest tenth of a millibar, as evideneed by occurrences of several (in one case, ix) consecutive monthly values containing a zero in the tenths place.

Soltware designed lo find deviations from the olherwise characteristle seasonal cycle of monthly mean barometric pressure observed at all 60) stations uncovered evidence of undocumented station moves at stations 57127, 57461, and 57516, oach orse having one or more years of pressure data with a markedly dilferent range as compared to prior or subsequent years. Other single-month values which departed stgnificantly from typical scasonal trends were llagged if not corroborated by noighboring stations.

\section{Temperature}

Checks for proper relationships between the various monthly mean/extreme temperatures have been made, and the relatively small number of errors found have been corrected through consultation with CAS.

Another simple check involved looking for statistical outliers by calculating the mein and standard deviation of the respective monthly values for all temperature variables from each station. Values lying 3.5 or more standard deviations away from the mean of the respective monthly values were llagged if not corroborated by temperatures at neighboring stations. Checking for departures from the characteristic seatsonal cycle of monthly mean temperature produed several values that, while not statistical outliers, were also flagged as suspect if they could not be eorroborated by monthly temperature trends from neighboring stations. The user is referred to the discussion of flag codes for the o(o-station data set in Sect. 12 for additional delails. 


\section{Total Precipitation}

QA checks basically focused on flagging very high totals and non-zero repeated totals. Totals exceeding $500 \mathrm{~mm}(\sim 20 \mathrm{in}$.) were found in 176 cases, and three of these totals exceeded $1 \mathrm{~m}$. Practically all of these totals were considered valid; they were received in the warmer half of the year in regions that typically experience monsoonal effects. However, the extremely high totals found in the original CAS data set for LaSa (No. 55591) for May-September of 1936 (486.5, 517.7, 2049.6, 1313.2, and $619.2 \mathrm{~mm}$, respectively) were considered suspect and replaced by totals for LaSa obtained from Eischeid et al. (1991). These totals are flagged in the file included with this package and are 48.5, 52.7, 205.0, 131.0, and $62.0 \mathrm{~mm}$ for May-September, respectively. Several high totals for other stations, while not edited, were also flagged, as were several non-zero identical totals over consecutive months (Sect. 12).

\section{Sunshinc Duration}

These data were checked for identical values over consecutive months. This type of oceurrence should be relatively rare since the monthly totals are rounded to the nearest tenth of an hour. Forty-nine pairs of months were found where this did occur. These values have been flagged (Sect. 12) so users may decide if they appear plausible (perhaps by considering cloud amounts or other data over these months).

Monthly maximum possible sunshine duration was calculated for each station using the station's latitude and assuming a smooth, spherical earth where the sun's rays would not be blocked by natuial or man-made obstructions. Using the maximum durations, monthly values of percentage of possible sunshine were calculated for each station and plotted versus corresponding monthly cloud amounts. The plots were examined for obvious outlier data points; ten points being flagged from ten different stations. The sun and cloud values producing these points were examined in the context of the range of sun and cloud data for the particular month and station so as to determine which value was spurious. These values were then set to the missing indicator "-9999". Documentation provided by CAS (Appendix A) points out that a significant number of estimates (not identified) are included in these data.

\section{Monthly Mcan Cloud Amount}

These data were simply checked for values $\leq 0$ or $2100 \%$. No values of $0 \%$ were found, but four values of $100 \%$ were found at four different stations. They are considered reasonable in light of the concurrent values of sunshine duration and relative humidity reported at each station. Documentation provided by CAS (Appendix A) points out that a significant number of estimates (not identified) are included in these data.

\section{Monthly Mean Relative Humidity}

These data were simply checked for values $\leq 0$ or $2100 \%$. None were found; the data appeared reasonabic upon cursory inspeciinit. 


\section{Total Number of Days with Snow Cover}

Monthly variations for stations reporting any days with snow cover seem reasonable, and no values exceeding the number of days in a particular month were found.

\section{Monthly Dominant Wind Direction and Dominant Wind Frequency}

Inconsistencies have been found in these data. The dominant wind direction is defined in Appendix A as the most frequent wind direction observed for the month, measured in $22.5^{\circ}$ increments of azimuth clockwise from north. A direction of $0^{\circ}$ is used to denote calm winds, while $360^{\circ}$ indicates a north wind. The data have been checked to make sure all dominant wind directions (if not set to the missing code "-9999") are $0^{\circ}$ or some multiple of $22.5^{\circ}$ up to $360^{\circ}$. Pre-1981 data show a large number of dominant wind directions with values of $0^{\circ}$, the extent of which varies greatly by individual station. This probably makes good physical sense, as diurnal variations alone in many areas could often be associated with lengthy periods of calm at night. However, all dominant wind directions for 1981-1983 are missing, and there are no values of $0^{\circ}$ for any station during the period 1984-1988. This most likely implies a change in the expression of dominant wind direction for the period 1984-1988, while the reason for missing data for 1981-1983 is unknown. Data prior to 1981 have reasonable values for dominant wind frequency, usually ranging from $\sim 10$ to $50 \%$. Frequencies for 1981-1983 are missing due to missing dominant wind direction, as are those for 1984-1988, even though values of unknown character are present for dominant wind direction. Taking these factors into consideration, the pre-1981 data are considered reasonable, but the nature of these data thereafter is unknown.

\section{Monthly Mean Wind Speed}

These data appear reasonable; values range from 0 to $9.4 \mathrm{~m} / \mathrm{s}$. Only one value of 0 was found (for December 1952 at Yi Ning, No. 51431), and since the dominant wind direction is given as $0^{\circ}$ (calm) the value has not been researched. (The dominant wind frequency is missing for this month).

\section{5-STATION NETWORK}

CAS provided data from these stations as separate temperature and precipitation files. These have been slightly reformatted to allow for the insertion of thags. QA checks and results for each data set are described in the following sections.

\section{Temperature}

Means and standard deviations of cach station's respective monthly values were calculated. Values lying 3.5 or more standard deviations away from their respective means were flagged if not corroborated by temperatures at neighboring stations. Checking for departures from the charanteristic seasonal cycle of monthly mean temperature produced 
several values that, while not statistical outliers, were deemed suspect if they could not be corroborated by monthly temperature trends from neighboring stations. For additional details of flag codes for the 205-station temperature data set, refer to Sect. 12.

\section{Total Precipitation}

QA checks focused on researching very high totals and flagging non-zero totals repeated over consecutive months. Several hundred totals exceeding $500 \mathrm{~mm}$ are present in the data, with three June totals from Heyuan (No. 59293) exceeding $1 \mathrm{~m}$. These Heyuan totals and several other especially large totals were researched by CAS and confirmed. All of these large amounts were received in the warmer half of the year in regions that typically experience monsoonal effects.

Many instances of identical non-zero totals over consecutive months were found in the data. These have been flagged as described in Sect. 12 for the 205-station precipitation data set.

\section{REFERENCES}

Bradley, R. S., P. M. Kelly, P. D. Jones, C. M. Goodess, and H. F. Diaz. 1985. A climatic data bank for northern hemisphere land areas, 1851-1980. DOE/EV/10739-2. Carbon Dioxide Research Division, U.S. Department of Energy, Washington, D.C.

Diaz, H. F., and $F_{1}$ Congbin. 1987. Regional precipitation and temperature variability and its relationship to the Southern Oscillation. pp. 213-223. In Y. Duzheng, F. Congbin, C. Jiping, and M. Yoshino (eds.), The Climate of China and Global Climate. China Ocean Press, Beijing.

Eischeid, J. K., H. F. Diaz, R. S. Bradley and P. D. Jones. 1991. A comprehensive precipitation data set for global land areas. DOE/ER-69017T-H1. Carbon Dioxide Research Division, U.S. Department of Energy, Washington, D.C.

Jones, P. D., S. C. B. Raper, B. Santer, B. S. G. Cherry, C. Goodess, P. M. Kelly, T. M. L. Wigley, R. S. Bradley, and H. F. Diaz. 1985. A grid point surface air temperature data set for the northern hemisphere. DOE/EV/10098-2. Carbon Dioxide Research Division, U.S. Department of Energy, Washington, D.C.

Jones, P. D., P. Ya. Groisman, M. Coughlan, N. Plummer, W.-C. Wang, and T. R. Karl. 1990. Assessment of urbanization effects in time series of surface air temperature over land. Nature 347:169-72.

Karl, T. R., and P. M. Steurer. 1990. Increased cloudiness in the United States during the first half of the twentieth century: Fact or fiction? Geophysical Research Letters 17(11):1925-28. 
Koomanoff, F. A., Ye Duzheng, Zhao Jianping, M. R. Riches, W.-C. Wang, and Tao Shiyan. 1988. The United States' Department of Energy and the People's Republic of China's Chinese Academy of Sciences joint rescarch on the greenhouse effect. Bulletin of the American Meteorological Society 69:1301-8.

Marland, G. and R. M. Rotty. 1984. Carbon dioxide emissions from fossil fuels: A procedure for estimation and results for 1950-1982. Tellus 36(B):232-61.

National Environmental Satellite, Data, and Information Service. 1981-1983. World Weather Records, 1961-1970) (Vols. 1-6). U.S. Department of Commeree, Washington, D.C.

Smithsonian Institution. 1927. World Weather Records, -1920. Miscellancous Collections, Volume 79. Washington, D.C.

Smithsonian Institution. 1934. World Weather Records, 1921-1930. Miscellaneous Collections, Volume 90. Washington, D.C.

Smithsonian Institution. 1947. World Weather Records, 1931-1940. Miscellaneous Collections, Volume 105. Washington, D.C.

Spangler, W. M. L. and R. L. Jenne. 1990. World Monthly Surface Station Climatology (And Associated Datasets). National Center for Atmospheric Research, Boulder, Colorado.

Steurer, P. M. and T. R. Karl. 1991. Historical sunshine and cloud data in the United States. ORNL/CDIAC-43. Carbon Dioxide Information Analysis Center, Oak Ridge National Laboratory, Oak Ridge, Tennessee.

U.S. Weather Bureau. 1959. World Weather Records, 1941-50 (Vols. 1-6). U.S. Department of Commerce, Washington, D.C.

U.S. Weather Bureau. 1967. World Weather Records, 1951-60 (Vols. 1-6). U.S. Department of Commerce, Washington, D.C.

Wang, W.-C., Z. M. Zeng, and T. R. Karl. 1990. Urban heat islands in China. Geophysical Research Letters 17(12):2377-80.

Zhang, M. L., Zeng Zhaomei, and Pan Yihang. 1987. The connection between the surface air temperature in the northern middle latitudes and the sea surface temperature in the tropical pacific. pp. 202-212. In Y. Duzheng, F. Congbin, C. Jiping, and M. Yoshino (eds.), The Climate of China and Global Climate. China Occan Press, Bcijing. 


\section{HOW TO OBTAIN THE DATA PACKAGE}

The PRC climate data files are available on request on a 9-track magnetic tape from CDIAC. This document and the magnetic tape are available free of charge. Requests for the magnetic tape should include any specific instructions for transmitting the data (c.g., 1600 or $6250 \mathrm{BPI}$ density, labeled or non-labeled, ASCII or EBCDIC characters, and block size or record length constraints) required by the user to access the data. Requests not accompanied by specific instructions will be filled on 9-track, $6250 \mathrm{BPI}$, standardlabeled tapes with characters written in EBCDIC. Requests should be addressed to:

Carbon Dioxide Information Analysis Center

Oak Ridge National Laboratory

Post Office Box 2008

Oak Ridge, Tennessee 37831-6335, U.S.A.

Telephone: (615) 574-0390

FTS $624-0390$

Fax: $\quad$ (615) $574-2232$

FTS $624-2232$

Electronic Mail: BITNET eMail: CDP@ORNLSTC INTERNET: CDP@STC10.CTD.ORNL.GOV OMNET: CDIAC 
49

PART 2

INFORMATION ABOUT THE MAGNETIC TAPE 


\section{CONTENTS OF THE MAGNEIIC TAPE}

The following is a list of files distributed on magnetic tape by CDIAC along with this documentation.

\begin{tabular}{|c|c|c|c|c|c|c|}
\hline & $\begin{array}{l}\text { lile number } \\
\text { and description }\end{array}$ & $\begin{array}{l}\text { Fife slize } \\
(\mathrm{k} / 3)\end{array}$ & $\begin{array}{l}\text { logleal } \\
\text { records }\end{array}$ & $\begin{array}{l}\text { Record } \\
\text { formatt }\end{array}$ & $\begin{array}{l}\text { Block } \\
\text { size. }\end{array}$ & $\begin{array}{l}\text { Record } \\
\text { length }\end{array}$ \\
\hline 1. & $\begin{array}{l}\text { General descriplive } \\
\text { informallion lile }\end{array}$ & 84.62 & 6.56 & $\mathrm{BH}$ & 6400 & 128 \\
\hline 2 & $\begin{array}{l}\text { LOR'IRAN IV data } \\
\text { retrieval code to } \\
\text { read and print the } \\
\text { station inventory from } \\
\text { the } 6(\text { )-stalion data sel } \\
\text { (lite 12) }\end{array}$ & 2.67 & 33 & 1313 & $80(1)$ & 80 \\
\hline 3. & $\begin{array}{l}\text { lOOR'IRAN IV data } \\
\text { retrieval code to } \\
\text { read and print the } \\
\text { station inventory from } \\
\text { the } 205 \text {-station data set } \\
\text { (lite } 13 \text { ) }\end{array}$ & 2.75 & .34 & FiB & 8()$(1)$ & 80 \\
\hline 4. & $\begin{array}{l}\text { JORTRAN IV di ta } \\
\text { retrieval code to } \\
\text { read and print the } \\
\text { o(j-station dalla set } \\
\text { (lite 14) }\end{array}$ & 3.08 & 38 & $\mathrm{FH}$ & $8(0)(x)$ & 80 \\
\hline 5. & $\begin{array}{l}\text { IOOR'IRAN IV data } \\
\text { retrieval code to } \\
\text { read and print the } \\
205 \text {-station temperature } \\
\text { data set (Iile } 1.5 \text { ) }\end{array}$ & 2.59 & 32 & $1: 13$ & $80(1)$ & $80)$ \\
\hline 6. & $\begin{array}{l}\text { DOR'IRAN IV data } \\
\text { retrieval code to } \\
\text { read and print the } \\
205 \text {-station precipitation } \\
\text { data set (I iile } 16 \text { ) }\end{array}$ & 2.51 & 31 & $\mathrm{FiB}$ & 800() & 8() \\
\hline 7. & 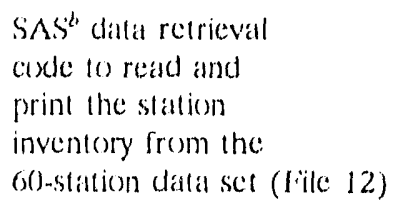 & 1.54 & 19 & {$[1]$} & $80(x)$ & 80 \\
\hline
\end{tabular}




\begin{tabular}{|c|c|c|c|c|c|c|}
\hline & $\begin{array}{l}\text { lifle number } \\
\text { and description }\end{array}$ & $\begin{array}{l}\text { lille slac } \\
(\mathrm{k}[3)\end{array}$ & $\begin{array}{l}\text { L.ogleal } \\
\text { records }\end{array}$ & $\begin{array}{l}\text { Record } \\
\text { format }\end{array}$ & $\begin{array}{l}\text { Block } \\
\text { sizec }\end{array}$ & $\begin{array}{l}\text { Record } \\
\text { length }\end{array}$ \\
\hline 8. & $\begin{array}{l}\text { SAS data retrieval } \\
\text { code to read and print } \\
\text { the station inventery } \\
\text { from the } 205 \text {-station } \\
\text { data set (litle 1.3) }\end{array}$ & 1.70 & 21 & l'13 & $80(0)$ & 80 \\
\hline 9. & $\begin{array}{l}\text { SAS data retrieval } \\
\text { code to read and print } \\
\text { the } 60 \text {-station diatla set } \\
\text { (1)ile 14) }\end{array}$ & 2.10 & 26 & 113 & 8000 & 80 \\
\hline 10. & $\begin{array}{l}\text { SAS data retrieval } \\
\text { code to read and print } \\
\text { the } 205 \text {-stattion temperature } \\
\text { data set (File 15) }\end{array}$ & 1.78 & 22 & IHI & 8000 & 80 \\
\hline 11. & $\begin{array}{l}\text { SAS data retrieval } \\
\text { code to read and print } \\
\text { the } 205 \text {-station precipitation } \\
\text { data set (lite 16) }\end{array}$ & 1.78 & 22 & 1013 & 8000 & 80 \\
\hline 12. & $\begin{array}{l}\text { Station inventory file } \\
\text { for the PRC } 60 \text {-station } \\
\text { climate data set }\end{array}$ & 3.18 & 60 & Iil3 & 5200 & 52 \\
\hline 13. & $\begin{array}{l}\text { Station Inventory file } \\
\text { for the PRC } 20.5 \text { station } \\
\text { tempeiature and precipitation } \\
\text { data sets }\end{array}$ & 13.74 & 20.5 & NBB & 6600 & 66 \\
\hline 14. & $\begin{array}{l}\text { PRR: } 6(\text { ).station } \\
\text { climate data set }\end{array}$ & 0.517 .21 & 50521 & liB3 & 6400 & 128 \\
\hline 15. & $\begin{array}{l}\text { PRRC: } 2015 \text { station } \\
\text { femperature dalta set }\end{array}$ & 1016.21 & 9155 & IFI3 & 8800 & 110 \\
\hline 16. & $\begin{array}{l}\text { PRC: } 205 \text { station } \\
\text { precipitation data set }\end{array}$ & 1008.55 & $90 \$ 6$ & I'13 & 8800 & 110 \\
\hline & Total size and records & 8666.01 & $6,9,961$ & & & \\
\hline
\end{tabular}

${ }^{a} \mathrm{~F} I 3=$ fixed block.

"SAS is a registered trademark of SAS Institute, Inc., Cary, North Carolina 27511-83000. 


\section{DESCRIPTIVE FILE ON THE MAGNETIC TAPE}

The following is a listing of the first file on the manetic lape distributed by CDIAC. This file is intended to provide the details (i.e., variable descriptions, formats, and units) of each life associated with this numeric data packnge.

\section{TITLE OF THE DATA SET}

Two Long-Term Instrumental Climatic Data Bases of the People's Republic of China

\section{DATA CONTRIBUTORS}

Tao Shiyan, Fu Congbin, Zeng Zhaomei, Zhang Qingyun

Institute of Atmospheric Physics

Chinese Academy of Sciences

Beijing, China

\section{SOURCE AND SCOPE OF THE DATA}

Two PRC elimate data bases, derlved mainly from instrument measurements, are presented in this package; one consists of monthly means, extremes, or totals of 14 meteorological variables observed at 60 stations, the other contains monthly mean temperatures and monthly precipitation totals from 205 stations. The two data bases have no stations in common. Each is described in detail in the following sections.

\section{0). Station Network}

As previously noted, the data from these 60 stations consist of monthly means, extremes, or totals of the following 14 meteorological variables:

- Mean Station Pressure (mb)

- Mean Temperature $\left({ }^{\circ} \mathrm{C}\right)$

- Mean Maximum Temperature $\left({ }^{\circ} \mathrm{C}\right)$

- Mean Minimum Temperature $\left({ }^{\circ} \mathrm{C}\right.$ )

- Total Precipitation (mm)

- Sunshine Duration (hours)

- Mcan Cloud Amount (percentage of sky cover)

- Mean Relative Humidity (pereent)

- Snow Days (days with snow cover)

- Dominant Wind Dircetion (degrees)

- Mcan Wind Speed (m/s)

- Dominant Wind Frequency (pereent)

- Extreme Maximum Temperature $\left({ }^{\circ} \mathrm{C}\right)$

- Extreme Minimum Temperature $\left({ }^{\circ} \mathrm{C}\right)$ 
Each record contains one month's data; the WMO station number, year, and month, followed by the data variables in the same order as previously listed. Each data value is given in tenths of its specilied unit of measure. Missing dala values are indicated by "-9999".

Four basic criteria were used in selecting stations to make up the 60)-station network: (1) the station should be representative of a particular climale region of China, (2) the station's data should be of relatively high quality, (3) the period of record of the station should be reasonably long, and (4) the resulting station network should have a relatively uniform spatial distribution. Thirteen stations began observing before 1900), Beijing's record is the longest, with temperature and precipitation data dating back $t(1841$. All 60) stations have temperature and/or precipitation data available from the beginning of their periods of record, with other types of observations beginning more randomly with time throughout the network. Records from all stations run through 1988, but extreme maximum and minimum temperature data are available for each station only sinec 1984. Nearly one-half of the 60 stations have some type of data for at least 70 years, but only six have dala for $1(H)$ years or more. Data are available firom all 6() stations over the period 1951-1988. Periods of whole years without data are omitted from the data set. Station histories are available for these stations and are contained in Appendix B of the document which accompanies this tape.

\section{5-Silation Network}

Data from the 205-station network contain two variables: monthly mean temperature and lotal monthly precipitation. The data are stored in two files, one with temperatures (in tenths of degrees Celsius) and the other with precipitation totals (in tenths of millimeters). Each record of a file contains data from one year: the WMO station number and year followed by twelve monthly data values. Missing values are represented by "-9999". The temperature data date back 101907 (Jingehou, No. 57476) and the precipitation data to 1880 (Wuhu, No. 58334). Temperature and precipitation records from 202 stations extend through 1988. Records from Geershiquanhe (No, 55228), Hekou (No, 56989), and Lingling (No. 57866) extend through 1982, 1980), and 1983, respectively. Because of their relatively small number, years without data have been left in these diata sets. For both temperature and precipitation data, the most typical length of record ranges between $30-40$ years, with a relatively small share of stations 129 stations $(-15 \%)$ for lemperature; 24 stations $(-12 \%)$ for precipitation] having records for 50 or more years. The 60)-station data set offers more truly long-term records and, as previously noted, contains temperature and/or precipitation data from the beginning of each station record. The lïst year for which all 205 stations have temperature and precipitation dalla is 1961. Unfortunately, station historics are not currently available for any of the stations in the 205-station network; therefore, details regarding instrumentation, collection methods, changes in station location or observing times, ard official data sources are not known. 


\section{DA'TA FORMA'T}

The information on this tape is arranged in sixtecn likes, containing the lonllowing:

- this descriptive ille

- live FOR'TRAN IV input/output routines (one por fllo)

- live SAS imput/output routines (one per fille)

- the station inventory for the PRC 6()-stallon network

- the station inventory for the PRC. 205-station network

- the 6()-station network climate data set

- the 205-station network temperature data set

- the 2(1)5-station network precipitalion data set

\section{STATION INVENTORY FILLE FOR THE PRC (X)SIA'TION NETWORK CI IMATE DA'TA SET'}

The station inventory file for the o().station climate data set (File 12 on the magnetic: liape) is sorted by 5-digit station number, with one record per station comtaining a sequence number $(1-6())$, station name, station number, latitude, longitude, elevaltion above sea level, and the beginning year of the station's record.

The file may be read using the following FOR'TRAN format:

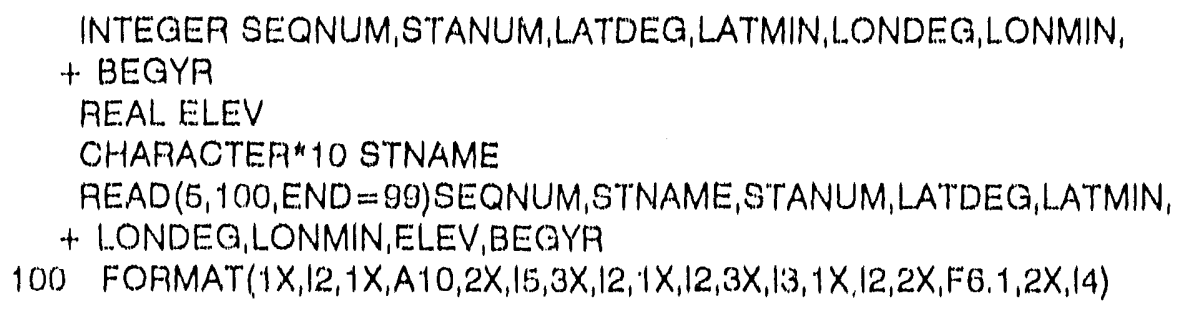

or by using the SAS format:

INPUT SEQNUM 2-3 STNAME \$ 5.14 STANUM 17.21 LATDEQ 25.26

LATMIN 28-29 LONDEG 33-35 LONMIN 37-38 ELEV 41-46 BEGYR 49-52

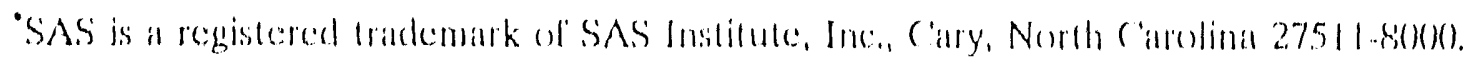


Stuted in tabulur form, the contents include the following.

\begin{tabular}{|c|c|c|c|c|}
\hline Variable & $\begin{array}{c}\text { Vuriuble } \\
\text { lype }\end{array}$ & $\begin{array}{l}\text { Vurluble } \\
\text { width }\end{array}$ & $\begin{array}{l}\text { Sturling } \\
\text { columnn }\end{array}$ & $\begin{array}{l}\text { Encling } \\
\text { column }\end{array}$ \\
\hline SEQNUM & Numeric: & 2 & 2 & 3 \\
\hline STNAME & Charactor & 10 & 5 & 14 \\
\hline S'I'ANUM & Numeric & 5 & 17 & 2.1 \\
\hline LATDEG & Numeric & 2 & 25 & 26 \\
\hline LA'TMIN & Numeric & 2 & 28 & 29 \\
\hline LONDEG & Numeric & 3 & 3.3 & 3.5 \\
\hline LONMIN & Numerlc: & 2 & 37 & 38 \\
\hline ELEV & Numeric & 6 & 41 & 46 \\
\hline BEOYR & Numeric & 4 & 49 & 52 \\
\hline
\end{tabular}

where

SEQNUM Lis the station's relative position in the fille $(1-60)$;

STNAME is the name of the station;

STANUM is the WMO station number;

LATDEG is the degrees portion of the station's latilude;

LATMIN is the minutes portion of the station's latitude;

LONDEG is the degrees (east) portion of the stalion's longitude;

LONMIN in the minutes portion of the station's longitude;

ElizV is the elevation of the station above sea level (m); and

BEGYR is the begimning year of the station's record. 


\section{S"TA'TION INVEN'TORY FILEZ IOR 'TIIE PRC 20S-S'I'A'IION NET'WORK 'TEMPERA'TURE AND PIRECIPITA'TION DA'TA SETIS'}

The station inventory fille for the 205 -station data sets (Fille 1.3 on the magnetic tape)

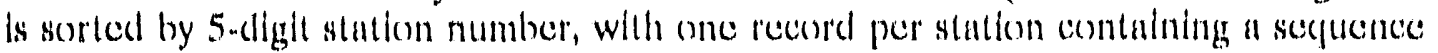
number (1-205), statlon name, station number, latlede, longilude, elevalion above sea level, and the beghning years of the station's temperuture and precipitation records.

The lile may be read using the following FORTRAN format:

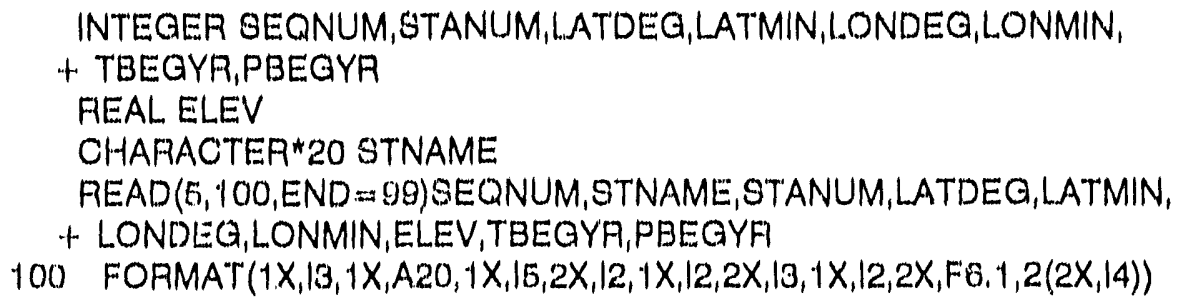

or by using the SAS format:

\section{INPUT SEQNUM 2-4 STNAME \$ 6-25 STANUM 27-31 LATDEG 34-35 LATMIN 37-38 LONDEG 41-43 LONMIN 45-46 ELEV 49-54 TBEGYA 57-60 PBEQYR 63-66}

Stated in labular form, the contents include the following.

\begin{tabular}{lcccc}
\hline Variable & $\begin{array}{l}\text { Variable } \\
\text { lype }\end{array}$ & $\begin{array}{c}\text { Variable } \\
\text { width }\end{array}$ & $\begin{array}{c}\text { Starting } \\
\text { column }\end{array}$ & $\begin{array}{l}\text { Ending } \\
\text { column }\end{array}$ \\
\hline SEQNUM & Numeric & 3 & 2 & 4 \\
STNAME & Character & 20 & 6 & 25 \\
STANUM & Numeric & 5 & 27 & 31 \\
LATDEG & Numeric & 2 & 34 & 35 \\
LATMIN & Numeric & 2 & 37 & 38 \\
LONDEG & Numeric & 3 & 41 & 43 \\
LONMIN & Numeric & 2 & 45 & 46 \\
E..EV & Numeric & 6 & 49 & 54 \\
TBEEYR & Numeric & 4 & 57 & 60 \\
PBEGYR & Numeric & 4 & 6.3 & 66 \\
\hline
\end{tabular}

where

SEQNUM is the station's relative position in the kile $(1-205)$; 
STNAME is the nume of the station;

STANUM is the WMO stution number:

LA'TDEG is the degrees portion of the stution's latitude;

LATMIN Is the minutes portion of the station's latitude;

LONDEG is the degrees (easi) portion of the station's longitude;

LONMIN is the minutes portion of the station's longitude;

ELEV is the elevation of the station above scil level (m);

TBEGYR is the beginning year of the station's temperature record; and

PBEGYR is the beginning year of the station's precipitation record.

\section{(6)-STATION NETWORK CLIMATE DATA FILE}

The climale data set from the 60-station network (File 14 on the magnetic tape) contains monthly measurements of 14 climatological variables. The data are sorted by station number, with each record containing data for one month, including station number, year, month, mean station pressure, mean temperature, mean maximum and minimum temperatures, total precipilation, sunshine duration, mean cloud amount, mean relative humidity, total days with snow cover, dominant wind direction, mean wind speed, dominant wind liequency, and extreme maximum and minimum temperatures for the month (1984-1988 only).

The file may be read using the following FORTRAN format:

INTEGER STANUM, YEAR,MON,PRES,MEANT,MEANMX,MEANMN, + PRECIP,SUN,CLD,RH,SNOW,WDIR,WSPD,WFREO, EXMX,EXMN

CHARACTER 1 RECF,PRESF,MEANTF,MXF,MNF,PRECF, SUNF,CLDF, + RHF,SNOWF,WDIRF,WSPDF,WFREQF, EXMXF,EXMNF

READ $(5,100, E N D=99) S T A N U M, Y E A F, M O N, R E C F, P R E S, P R E S F, M E A N T$,

+ MEANTF,MEANMX,MXF,MEANMN,MNF,PRECIP,PRECF, SUN,SUNF,

+ CLD,CLDF, RH, RH F, SNOW, SNOWF,WDIR,WDIRF,WSPD,WSPDF,

+ WFREQ,WFREQF, EXMX,EXMXF, EXMN, EXMNF 
or by wising the SAS format:

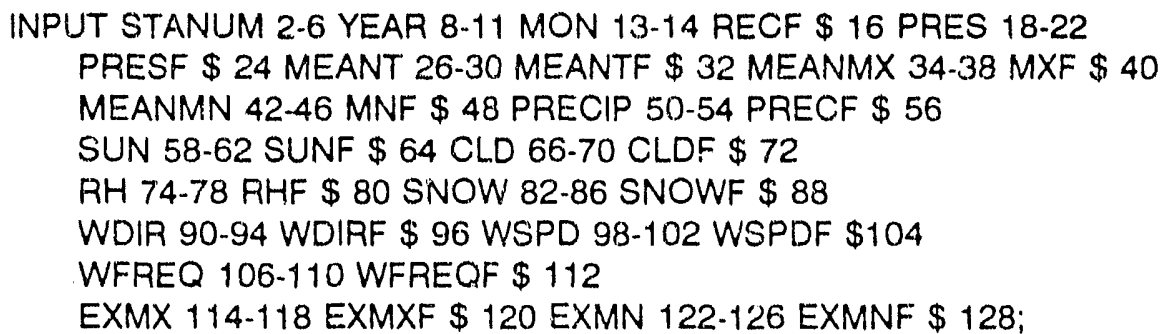

Stated in tabular form, the contents include the following.

\begin{tabular}{|c|c|c|c|c|}
\hline Variable & $\begin{array}{c}\text { Variable } \\
\text { type }\end{array}$ & $\begin{array}{l}\text { Variable } \\
\text { width }\end{array}$ & $\begin{array}{l}\text { Starting } \\
\text { column }\end{array}$ & $\begin{array}{l}\text { Ending } \\
\text { column }\end{array}$ \\
\hline STANUM & Numeric & 5 & 2 & 6 \\
\hline YEAR & Numeric & 4 & 8 & 11 \\
\hline MON & Numeric & 2 & 13 & 14 \\
\hline RECF & Character & 1 & 16 & 16 \\
\hline PRES & Numeric & 5 & 18 & 22 \\
\hline PRESF & Character & 1 & 24 & 24 \\
\hline MEANT & Numeric & 5 & 26 & 30 \\
\hline MEANTF & Character & 1 & 32 & 32 \\
\hline MEANMX & Numeric & 5 & 34 & 38 \\
\hline MXF & Character & 1 & 40 & 40 \\
\hline MEANMN & Numeric & 5 & 42 & 46 \\
\hline MNF & Character & 1 & 48 & 48 \\
\hline PRECIP & Numeric & 5 & 50 & 34 \\
\hline PRECF & Character & 1 & 56 & 56 \\
\hline SUN & Numeric & 5 & 58 & 62 \\
\hline SUNF & Character & 1 & 64 & 64 \\
\hline CLD & Numeric & 5 & 66 & 70 \\
\hline CLDF & Character & 1 & 72 & 72 \\
\hline RH & Numeric & 5 & 74 & 78 \\
\hline RHF & Character & 1 & 80 & 80 \\
\hline SNOW & Numeric & 5 & 82 & 86 \\
\hline SNOWF & Character & 1 & 88 & 88 \\
\hline WDIR & Numeric & 5 & 90 & 94 \\
\hline WDIRF & Characier & 1 & 96 & 96 \\
\hline WSPD & Numeric & 5 & 98 & 102 \\
\hline WSPDF & Character & 1 & 104 & 104 \\
\hline WFREQ & Numeric & 5 & 106 & 110 \\
\hline WFRFQF & Character & 1 & 112 & 112 \\
\hline
\end{tabular}




\begin{tabular}{lcccc}
\hline Variable & $\begin{array}{c}\text { Variable } \\
\text { type }\end{array}$ & $\begin{array}{c}\text { Variable } \\
\text { width }\end{array}$ & $\begin{array}{c}\text { Starting } \\
\text { column }\end{array}$ & $\begin{array}{c}\text { Ending } \\
\text { column }\end{array}$ \\
\hline EXMX & Numeric & 5 & 114 & 118 \\
EXMXF & Character & 1 & 120 & 120 \\
EXMN & Numeric & 5 & 122 & 126 \\
EXMNF & Character & 1 & 128 & 128 \\
\hline
\end{tabular}

where

STANUM is the WMO station number;

YEAR is the year of the data;

MON is the month of the data;

PRES is the monthly mean station pressure $(\mathrm{mb})$;

MEANT is the monthly mean temperature $\left({ }^{\circ} \mathrm{C}\right)$;

MEANMX is the monthly mean of the daily maximum temperatures $\left({ }^{\circ} \mathrm{C}\right)$;

MEANMN is the monthly mean of the daily minimum temperatures $\left({ }^{\circ} \mathrm{C}\right)$;

PRECIP is the total precipitation (liquid and equivalent liquid of frozen precipitation) for the month ( $\mathrm{mm})$;

SUN is the total sunshine duration for the month (hr);

CLD is the mean cloud amount for the month (percent of sky cover);

$\mathrm{RH} \quad$ is the mean relative humidity for the month (percent);

SNOW is the number of days in the month with measurable snow cover;

WDIR is the dominant (most frequent) wind direction observed over the month, measured in $22.5^{\circ}$ increments of azimuth clockwise from north $\left(0^{\circ}\right.$ indicates calm winds, while $360^{\circ}$ indicates a nurth wind);

WSPD is the mean wind speed for the month $(\mathrm{m} / \mathrm{s})$;

WFREQ is the dominant wind frequency for the month (percent);

EXMX is the extreme maximum temperature observed for the month $\left({ }^{\circ} \mathrm{C}\right)$; and 
EXMN is the extreme minimum temperature observed for the month $\left({ }^{\circ} \mathrm{C}\right)$.

All of the above meteorological variables are expressed in tenths of their specific units of measure.

\section{Flag codes for the data}

REC.F is a flag denoting if any observations in the record have been corrected using other sources or flagged as being suspect. The following codes indicate which values have been flagged:

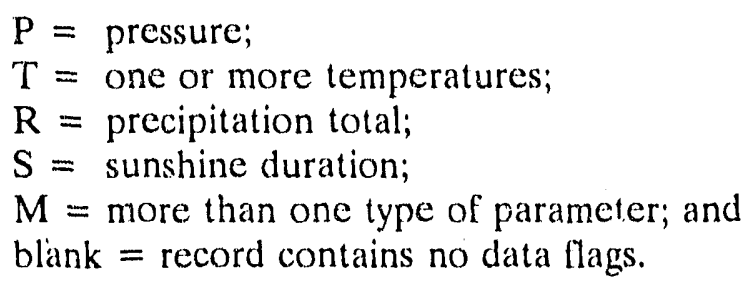

PRESF is the pressure value flag. The codes are as follows:

$$
\begin{aligned}
& \mathrm{T}=\text { the pressure departs from general monthly trends; } \\
& \text { and } \\
& \mathrm{E}=\begin{array}{l}
\text { pressure values for this year suggest a prior or subsequent } \\
\text { change in barometer elevation not noted in the station history. }
\end{array}
\end{aligned}
$$

MEANTF is a flag denoting suspect values of mean monthly temperature. The codes are as follows:

$A=$ outlier value; not consistent with other reported mean temperature variables for this month;

$\mathrm{B}=$ outlier value; repeated the following month;

$\mathrm{C}=$ outlier value;

$D=$ value is identical to previous month's value;

$\mathrm{E}=$ value does not fit typical monthly trends and is inconsistent with other reported mean temperature variables for the month;

$F=$ value is the highest ever reported for this month at this station and is repeated the following month;

$\mathrm{G}=$ value is identical to previous month's value, which has been flagged as being suspect; and

$\mathrm{H}=$ all three mean temperature variables have identical values over May and June of the current year.

\footnotetext{
Defined ats lying 3.5 or more standard deviations away from the mean value of the variable.
} 
MXF is a flag denoting suspect values of monthly mean maximum temperature. The codes include $A, D, E$, and $H$ from the aforementioned MEANTF llag, in addition to the following:

$$
I=\text { outlier value; likely caused by an error in sign. }
$$

MNF is a flag denoting suspect values of monthly mean minimum temperature. The codes are A, D, E, H, and I from the alorementioned MEANTF and MXF flags.

PRECF is the precipitation total flag. The codes are as follow:

$$
\begin{aligned}
R= & \text { total is identical to the previous or following month's total; } \\
H= & \text { total is especially high for this station and is considered suspect; } \\
& \text { and; } \\
E= & \text { original total was considered suspect due to being especially } \\
& \text { high for the station. It has been replaced by data from } \\
& \text { Eischeid et al. (1991). }
\end{aligned}
$$

SUNF is the sunshine duration flag. The code used is:

$$
\mathrm{R}=\text { total is identical to the previous or following month's total. }
$$

The data flags CLDF, RHF, SNOWF, WDIRF, WSPDF, WFREQF, EXMXF, and EXMNF are not used in the current version of the 60-station data set (their storage locations contain only blanks) because, of their associated variables, only the dominant wind direction data contain values of a questionable nature. Pre-1981 data contain a considerable number of dominant wind directions of $0^{\circ}$ (calm winds), whereas data from the period 1984-1988 contain none. (Dominant wind direction data for the period $1981-1983$ are missing.)

\section{5-STATION MONTHLY MEAN TEMPERATURE FILE}

The temperature data set from the 205-station network (File 15 on the magnetic tape) contains monthly mean temperatures. The data are sorted by station number, with each record containing data for one year, including station number, year, and mean temperatures for January through December. Temperatures are given in tenths of degrees Celsius.

The file may be read using the following FORTRAN format:

INTEGER STANUM, YEAR, TEMP(12)

CHARACTER*1 RFLAG, TFLAG(12)

READ $(5,100, E N D=99)$ STANUM, YEAR, RFLAG,

$+(\operatorname{TEMP}(1), \operatorname{TFLAG}(1), 1=1,12)$

100 FORMAT $(2 \mid 6,1 X, A 1,12(\mid 6,1 X, A 1))$ 
or by using the SAS format:

INPUT STANUM 2-6 YEAR 9-12 RFLAG \$ 14

JAN 16-20 JANFL \$22 FEB 24-28 FEBFL \$ 30 MAR 32-36 MARFL \$ 38

APR 40-44 APRFL \$ 46 MAY 48-52 MAYFL \$ 54 JUN 56-60 JUNFL \$ 62

JUL 64-68 JULFL \$ 70 AUG 72-76 AUGFL \$ 78 SEP 80-84 SEPFL \$ 86

OCT 88-92 OCTFL \$94 NOV 96-100 NOVFL \$ DEC 104-108 DECFL \$110

Stated in tabular form, using variable names from the SAS format, the contents include the following.

\begin{tabular}{|c|c|c|c|c|}
\hline Variable & $\begin{array}{l}\text { Variable } \\
\text { type }\end{array}$ & $\begin{array}{l}\text { Variable } \\
\text { width }\end{array}$ & $\begin{array}{l}\text { Starting } \\
\text { column }\end{array}$ & $\begin{array}{l}\text { Ending } \\
\text { column }\end{array}$ \\
\hline STANUM & Numeric & 5 & 2 & 6 \\
\hline YEAR & Numeric & 4 & 9 & 12 \\
\hline RFLAG & Character & 1 & 14 & 14 \\
\hline JAN & Numeric & 5 & 16 & 20 \\
\hline JANFL & Character & 1 & 22 & 22 \\
\hline FEB & Numeric & 5 & 24 & 28 \\
\hline FEBFL & Character & 1 & 30 & 30 \\
\hline MAR & Numeric & 5 & 32 & 36 \\
\hline MARFL & Character & 1. & 38 & 38 \\
\hline APR & Numeric & 5 & 40 & 44 \\
\hline APRFL & Character & 1 & 46 & 46 \\
\hline MAY & Numeric & 5 & 48 & 52 \\
\hline MAYFL & Character & 1 & 54 & 54 \\
\hline JUN & Numeric & 5 & 56 & 60 \\
\hline JUNFL & Character & 1 & 62 & 62 \\
\hline JUL & Numeric & 5 & 64 & 68 \\
\hline JULFL & Character & 1 & 70 & 70 \\
\hline $\mathrm{AUG}$ & Numeric & 5 & 72 & 76 \\
\hline AUGFL & Character & 1 & 78 & 78 \\
\hline SEP & Numeric & 5 & 80 & 84 \\
\hline SEPFL & Character & 1 & 86 & 86 \\
\hline $\mathrm{OCT}$ & Numeric & 5 & 88 & 92 \\
\hline OCTFL & Character & 1 & 94 & 94 \\
\hline NOV & Numeric & 5 & 96 & 100 \\
\hline NOVFL & Character & 1 & 102 & 102 \\
\hline $\mathrm{DEC}$ & Numeric & 5 & 104 & 108 \\
\hline DECFL & Character & 1 & 110 & 110 \\
\hline
\end{tabular}


where

STANUM is the WMO station number;

YEAR is the year of the data; and

JAN-DEC are the monthly mean temperatures, given in tenths of degrees Celsius.

Flag codes for the data

RFLAG is a flag denoting whether any observations in the record are considered suspect and/or have been flagged. The codes are as follows:

$X=$ one or more temperatures have been flagged;

$\mathrm{Z}=$ the record is not recommended for use due to a spurious series of at least three consecutive monihly values; and blank = the record contains no data flags.

JANFL-DECFL are llags denoting suspect temperature values. The codes are as follows:

$A=$ outlier value ; departs from typical monthly trends;

$B=$ outlier value; likely caused by an error in sign;

$\mathrm{C}=$ outlier value; repeated the following month;

$D=$ outlier value; identical to previous month's value;

$E=$ outlier value;

$\mathrm{F}=$ value is identical to the previous month's value;

$\mathrm{G}=$ this station (No. 54852) shows identical July and August temperatures over the period 1973-1975;

$\mathrm{H}=$ this station (No. 57411) shows two pairs of repeated temperatures over the period May-August 1969. The values are not statistical outliers, but their pattern makes them suspect; and

$I=$ this station (No. 58734) has repeated temperatures for October-December 1945; the December value is an outlier.

\section{5-STATION PRECIPITATION FILE}

The precipitation data set from the 205-station network (File 16 on the magnetic tape) contains monthly precipitation totals. The data are sorted by station number, with each record containing data for one year, including station number, year, and precipitation totals for January-December (in tenths of millimeters).

\footnotetext{
Befined as lying 3.5 or more standard deviations awaly from the mean value of the vartathe.
} 
The lile may be read using the following FORTRAN format:

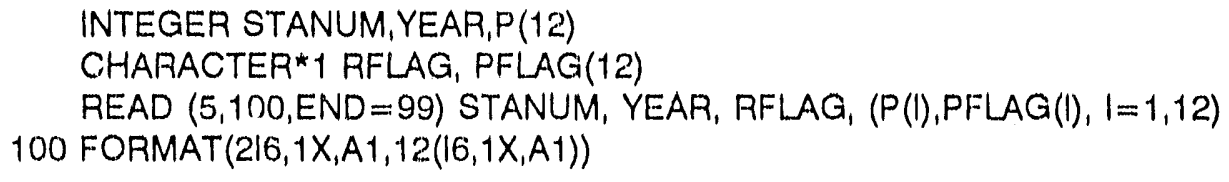

or by using the SAS format:

INPUT STANUM 2-6 YEAP 9.12 RFLAG $\$ 14$

JAN 16-20 JANFL \$22 FEB 24-28 FEBFL \$30 MAR 32-36 MARFL \$38

APR 40.44 APRFL \$ 46 MAY 48-52 MAYFL \$ 54 JUN 56-60 JUNFL \$ 62 JUL 64-68 JULFL \$ 70 AUG 72-76 AUGFL \$ 78 SEP 80-84 SEPFL \$ 86

OCT 88-92 OCTFL \$ 94 NOV 96.100 NOVFL \$ DEC 104-108 DECFL \$110

Stated in tabular form, using variable names from the SAS format, the contents include the following.

\begin{tabular}{|c|c|c|c|c|}
\hline Variable & $\begin{array}{c}\text { Variable } \\
\text { type }\end{array}$ & $\begin{array}{l}\text { Variable } \\
\text { width }\end{array}$ & $\begin{array}{l}\text { Starting } \\
\text { column }\end{array}$ & $\begin{array}{l}\text { Ending } \\
\text { column }\end{array}$ \\
\hline STANUM & Numeric & 5 & 2 & 6 \\
\hline YEAR & Numeric: & 4 & 9 & 12 \\
\hline RFLAG & Character & 1 & 14 & 14 \\
\hline IAN & Numeric & 5 & 16 & 20 \\
\hline JANFL & Character & 1 & 22 & 22 \\
\hline $\mathrm{FEB}$ & Numeric & 5 & 24 & 28 \\
\hline FEBFL & Character & 1 & 30 & 30 \\
\hline MAR & Numeric & 5 & 32 & 36 \\
\hline MARFL & Character & 1 & 38 & 38 \\
\hline APR & Numeric & 5 & 40 & 44 \\
\hline APRFL & Character & 1 & 46 & 46 \\
\hline MAY & Numeric & 5 & 48 & 52 \\
\hline MAYFL & Character & 1 & 54 & 54 \\
\hline JUN & Numeric & 5 & 56 & 60 \\
\hline JUNFL & Character & 1 & 62 & 62 \\
\hline JUL & Numeric & 5 & 64 & 68 \\
\hline JULFL & Character & 1 & 70 & 70 \\
\hline AUG & Numeric & 5 & 72 & 76 \\
\hline AUGFL & Character & 1 & 78 & 78 \\
\hline SEP & Numeric & 5 & 80 & 84 \\
\hline SEPFL & Character & 1 & 86 & 86 \\
\hline $\mathrm{OCT}^{\mathrm{T}}$ & Numcric & 5 & 88 & 92 \\
\hline OCTFL & Character & 1 & 94 & 94 \\
\hline
\end{tabular}




\begin{tabular}{lcccc}
\hline Variable & $\begin{array}{c}\text { Variable } \\
\text { lype }\end{array}$ & $\begin{array}{c}\text { Variable } \\
\text { width }\end{array}$ & $\begin{array}{c}\text { Starting } \\
\text { column }\end{array}$ & $\begin{array}{c}\text { Ending } \\
\text { column }\end{array}$ \\
\hline NOV & Numcric & 5 & 96 & 10() \\
NOVFL. & Character & 1 & 102 & $1(12$ \\
DEC & Numeric & 5 & 104 & 108 \\
DECFL & Character & 1 & 110 & 110 \\
\hline
\end{tabular}

where

STANUM is the WMO station number;

YEAR is the jear of the data; and

JAN-DEC are the monthly precipitation totals, given in tenths of millimeters.

Flag code; for the data

RFLAG is a flag denoting if any observations in the record have been flagged as being suspect. The codes are as follows:

$\mathrm{X}=$ one or more precipitation totals have been llagged; and blank = the record contains no data flags.

JANFL-DECFL are flags denoting suspect precipitation values. The single code used is:

$\mathrm{R}=$ total is repeated over consecutive months. Totals $\leq 1.0 \mathrm{~mm}$ repeated over two or more consecutive months were not flagged. If all entries in records containing repeated totals contained zeros in their tenths place, the repeated totals were only flagged if they were $\geq 10.0 \mathrm{~mm}$. All non-zero totals repeated over three consecutive months were flagged regardless of magnitude.

\section{REFERENCES}

Eischeid, J. K., H. F. Diaz, R. S. Bradley, and P. D. Jones. 1991. A eomprehensive precipitation data set for global land areas. DOE/ER-69017T-H1. Carbon Dioxide Research Division, U.S. Department of Encrgy, Washington, D.C. 


\section{LISTINGS OF THE FORTRAN IV DATA RETRIEVAL PROGRAMS}

The following is a listing of the FORTRAN IV dala retricval program provided on magnetic tape (File 2 on the tape) by CDIAC for reading and printing the station inventory life for the 6()-station data set (File 12 on the tape). The job control langunge (JCL) statements (preceded by $/ /$ or $/{ }^{*}$ ) shown in the following are not provided in the file on the magnetic tape. 'The JCL statements required will vary for each operating system. The JCL statements in the following are provided to illustrate the statements required by an individual at ORNL who has requested these clata on a nince-track, 6250 BPI, standard-labeled tape with characters written in EBCDIC and who is attempting to read the tape on an IBM mainframe (e.g., IBM 3090).

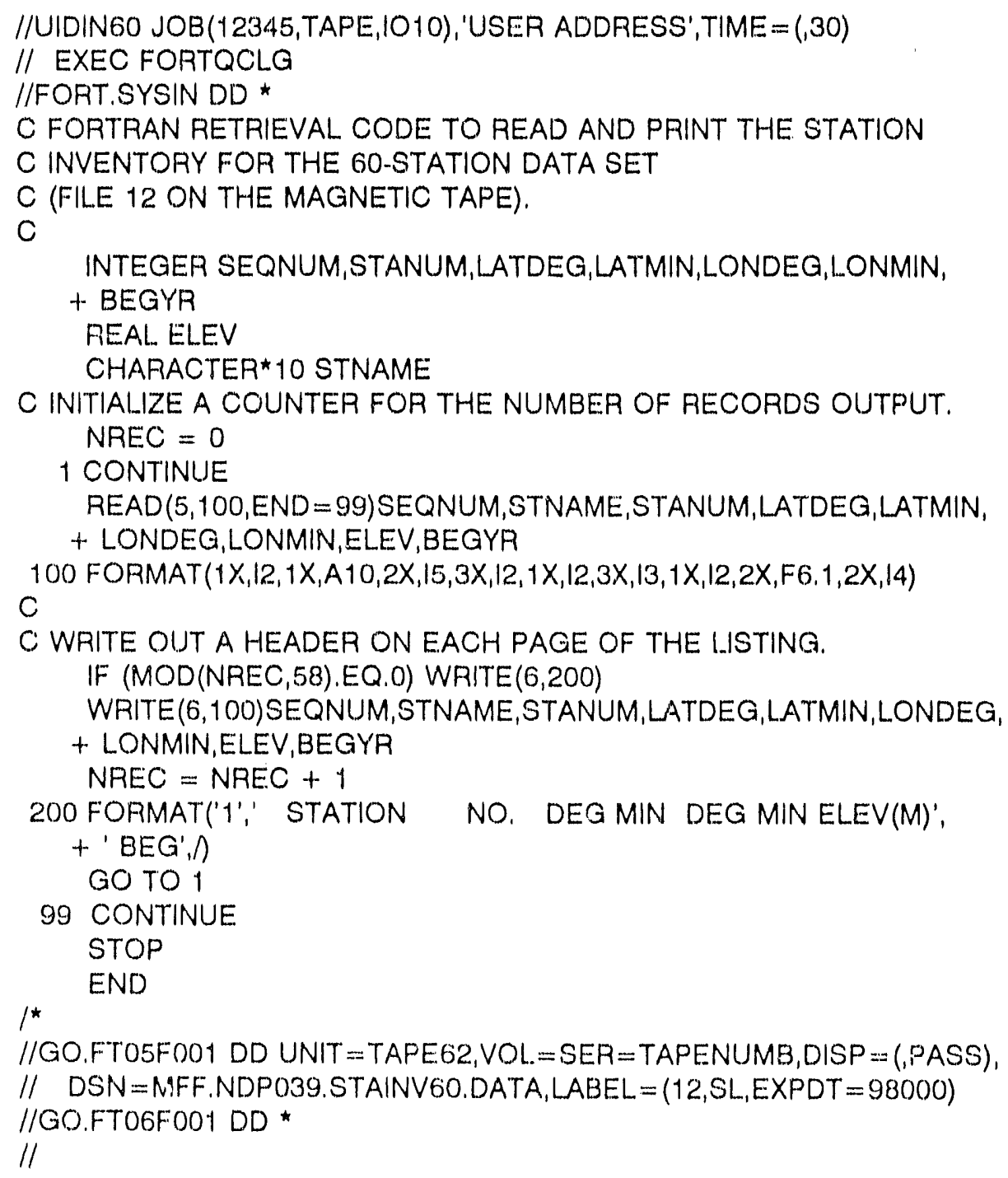


The following is a listing of the ROR'TRAN IV dala retricval program provided on mugnetic tape (File 3 on the tape) by CDIAC for reading and printing the station inventory lite lior the 20.5 -station datu sets (File 1.3 on the tape). The JCL stulements (preceded by $/ /$ or $/ *$ ) shown in the following are not provided in the fille on the mangetic lape. The JCL stalements reguired will vary for ench operating system. The JCL.

statements shown in the following are provided to fllustrate the statements required by an individual at ORNL who has recuested these data on a nine-track, 6250 BPI, standard. labeled lape with characters written in EBCDIC and whe is allempling to read the tape on an IBM malnfiame (e.g., IBM 3(1)90).

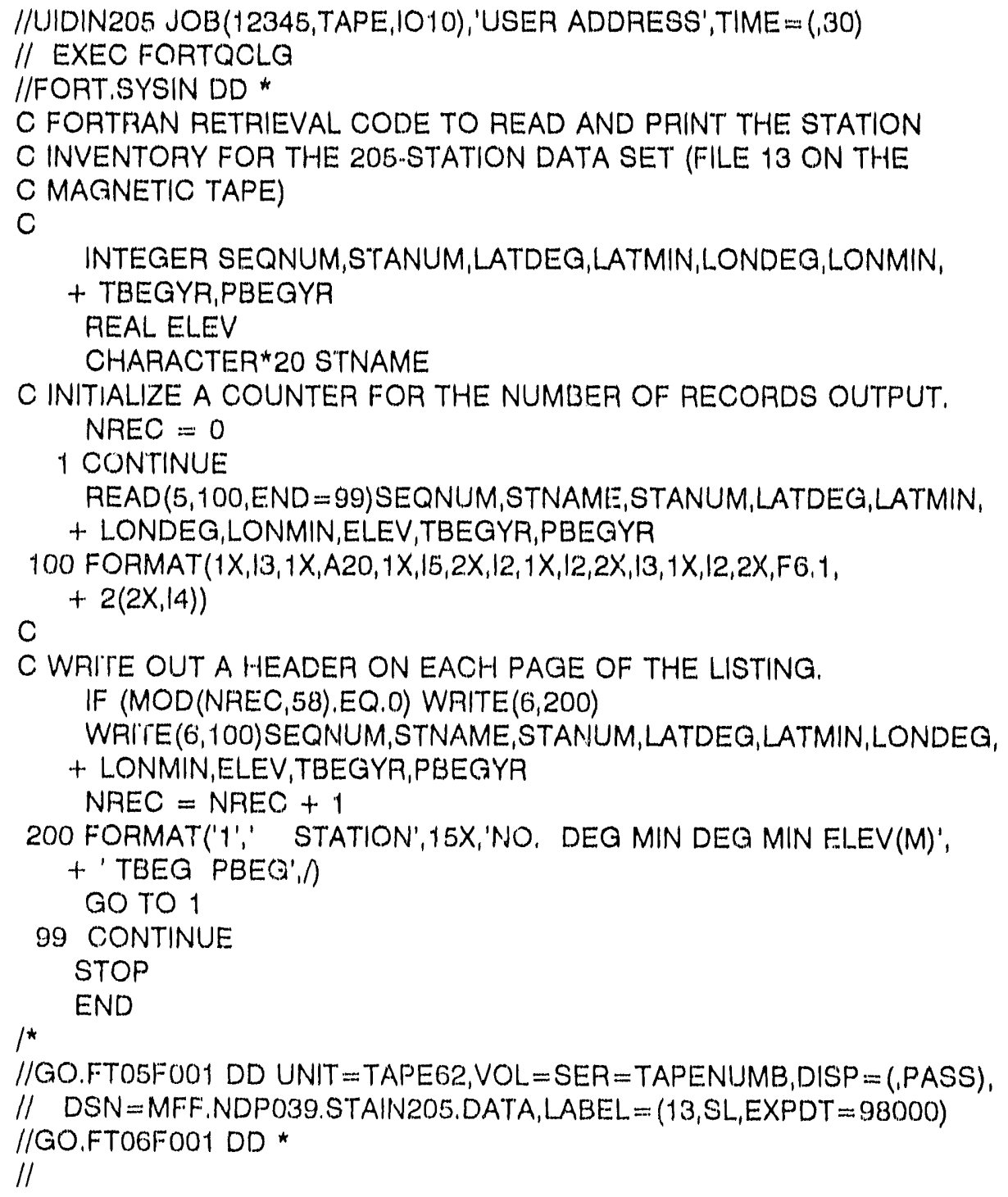


'The following is a listing of the fOOR'TRAN IV dala redricval program provided on

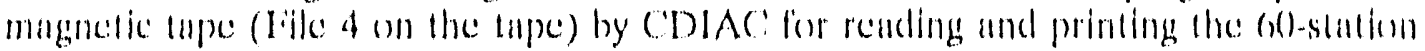

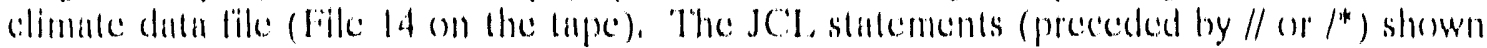

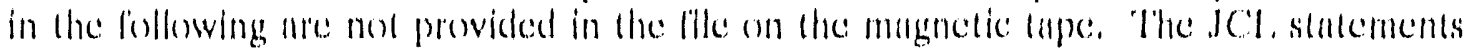

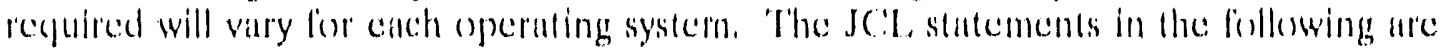
provided lo illustrate the statements regulred by an individual at ORNL, who has

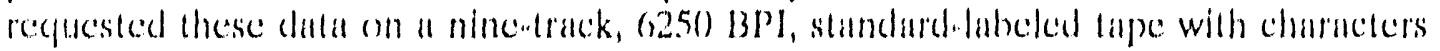
writlen in BBCDIC and who is attempting lo read the lape on an IBM mainliame (ceg., IBSM $3(1)(1))$.

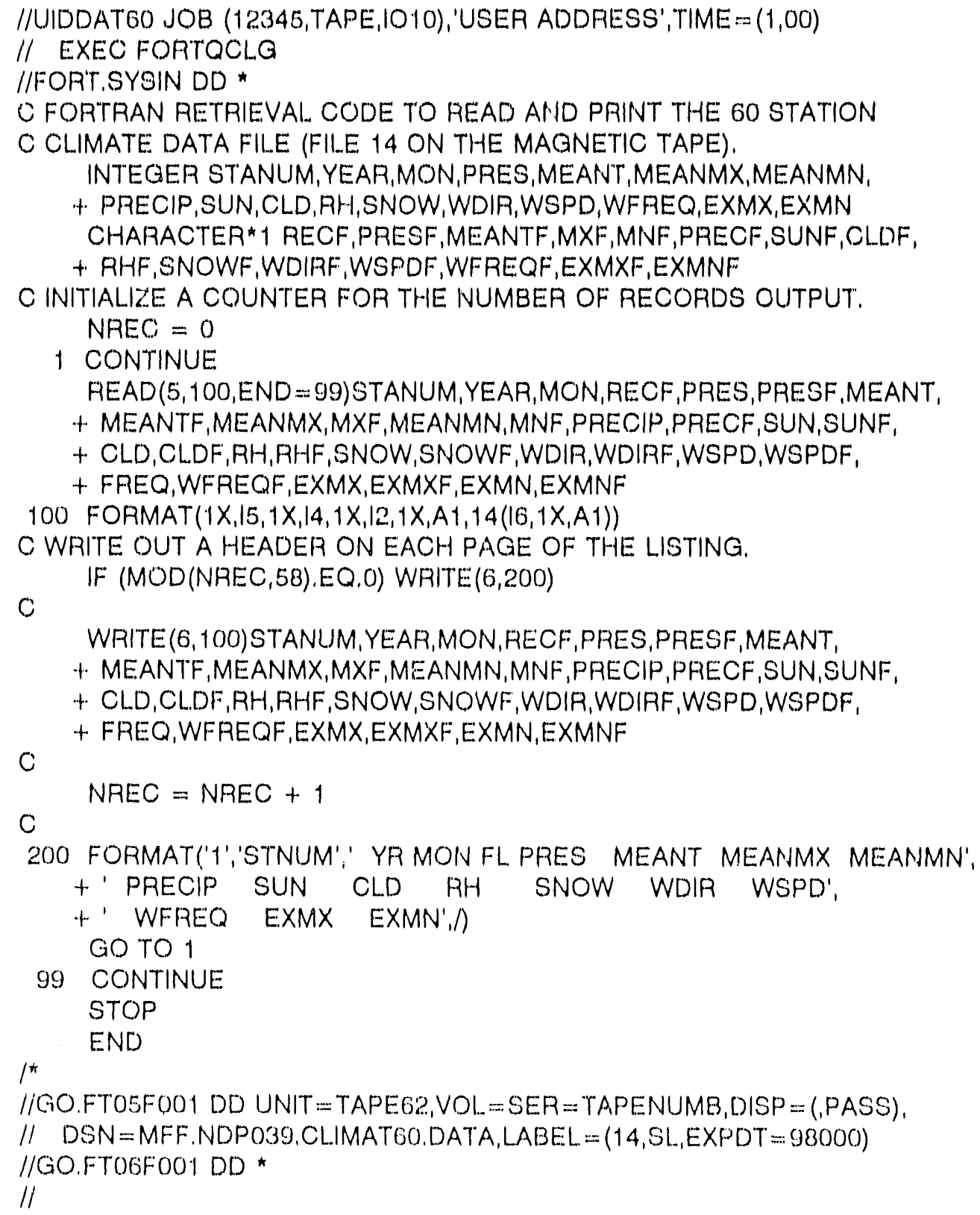


The following is a lisilng of the FORTRAN IV dinta retrieval program provided on magnefic tape (File 5 on the tape) by CDIAC for reading and printing the 2015station monthly mean comperature file (File 15 on the lape). The JCL stotements (preceded by /I or $/{ }^{*}$ ) shown in the following are not proveled in the lile on the magnetic lapes. The JCL. statements recpuired will vary for each operaling system. The JCL stalcments shown in the lollowing are provided to illustrute the stalcoments reguired by an individual at ORNL. whos has reguested these dala on a nine-track, 6250 B1'l, standard-labeled lape wilh characters wrillen in EBBCDIC and who is altempting to read the lape on an IBM mainframe (e.g., IBM $3(3)())$.

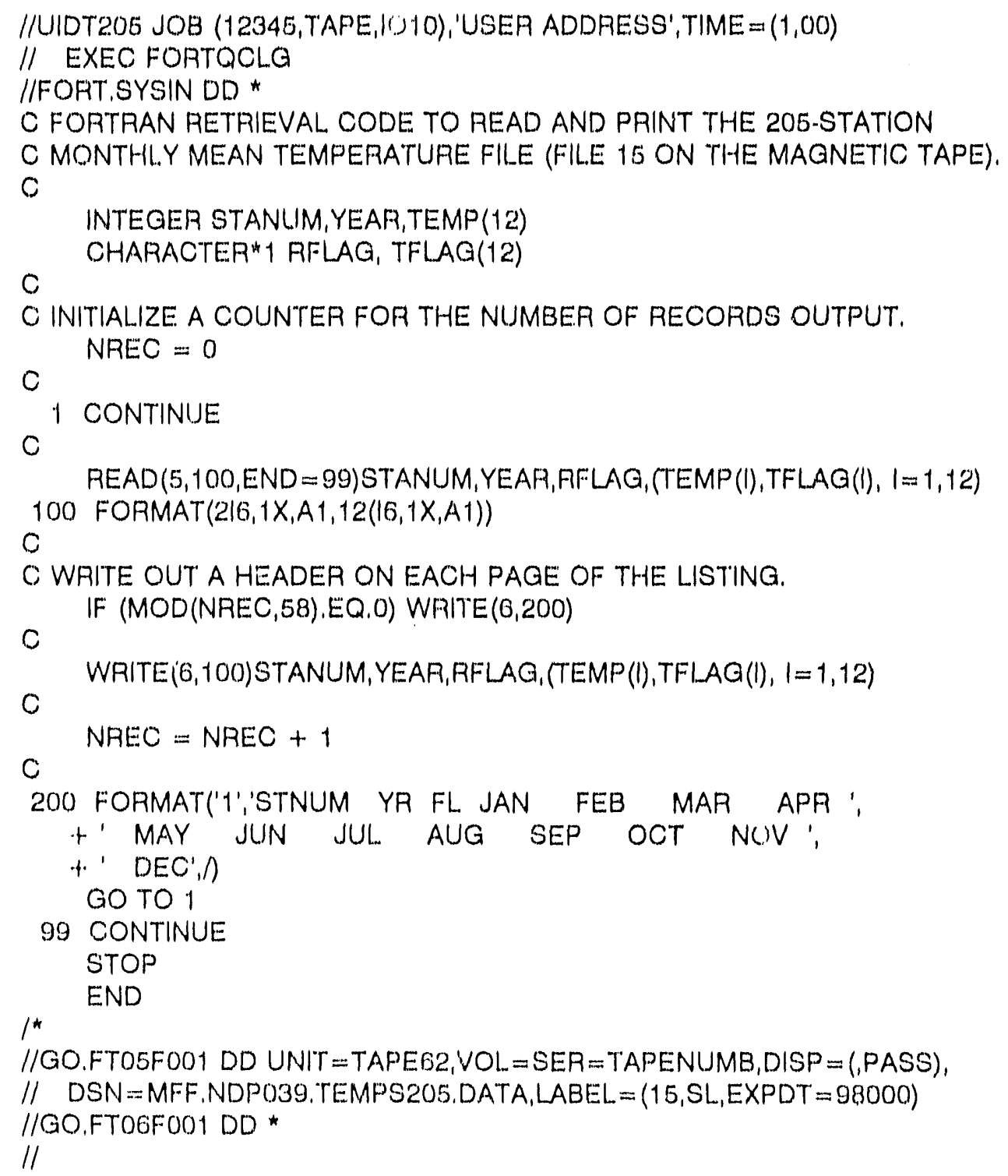


The following is a listing of the FORTRAN IV dula retricval program provided on magnetie tape (Flle 6 on the tape) by CDIAC lor reading and printing the 2015-station monthly precipitallon tille (File 16 on the tapes). The JCL statements (preceded by $/ /$ or $1^{*}$ ) shown in the following are not provided in the file on the manetic tape. The JCI. stulements repuired will vary for each operating system, The JCL. statements shown in the lollowing are provided to lllustrate the statements required by an indlividual at ORNL. who has requested these data on a nine-track, $6250 \mathrm{BPI}$, standard-labeled tape with characters written in EBCDIC and who is attempting to read the tape on an IBM matriframe (e.g., IBM $3(5)())$,

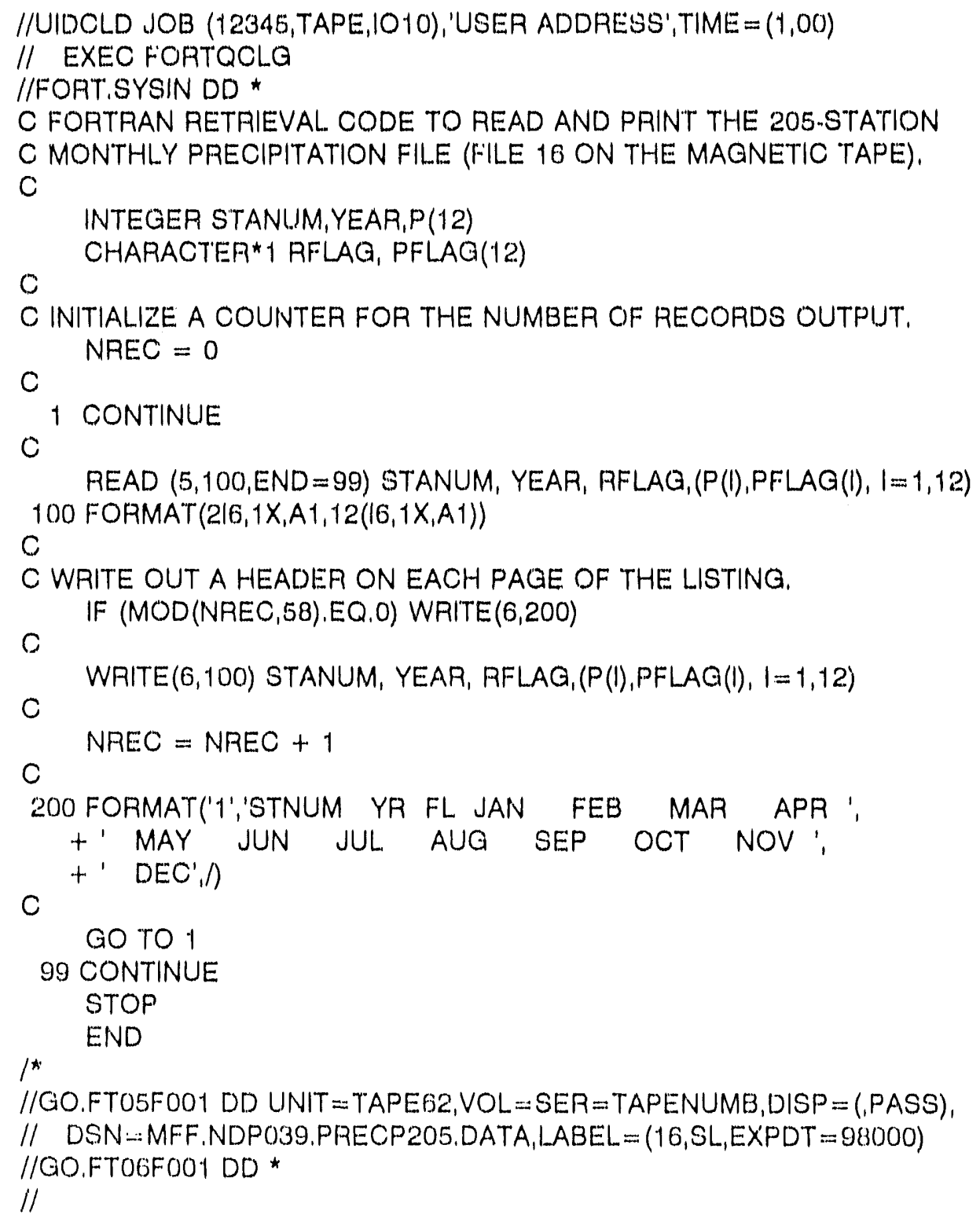




\section{LIS'IINGS OF 'THE SAS INPU'T/OU'TPU'T RETRIIEVAL, PROGRAMS}

The following is a listing of the SAS data retriceval progrma provided on magnetio tape (File 7 on the tape) by CDIAC for reading and printing the station inventery fille for the o()-sitation data set (Fille 12 on the tape). The JCL statements (preceded by // or /*) shown in the following are not provided in the file on the magnetio tape. The JCL stalements required will vary for each oporatling system. The JCL, stalements shown in the following are provided to lllustrate the statements required by an lidedvidual at ORNL. who has recpuested these data on a nincentrack, 6250) BPl, standard-labeled lape with sharacters written In EBCDIC and who is ntlempting to fead the tape on an IBM mainfiame (c.g." IBM 3()$(1)$,

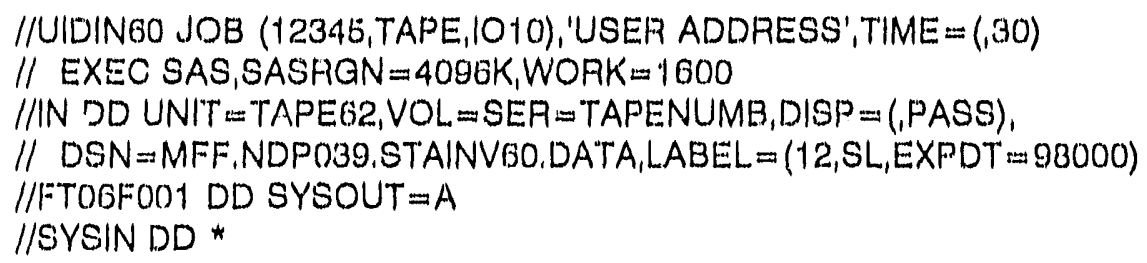

* SAS RETRIEVAL CODE TO READ AND PAINT THE GTATION INVENTORY FILE FOR THE 60-STATION DATA SET (FILE I2 ON THE MAGNETIC TAPE);

DATA INV60;

INFILE IN:

INPUT SEQNUM 2.3 STNAME \$ 6.14 STANUM 17-21 LATDEG 25.20

LATMIN 28.29 LONDEG 33-36 LONMIN 37-38 ELEV 41.46 BEGYA 49-62;

FILE PRINT NOTITLE HEADER=NEWPAGE;

PUT INFILE:

RETUTRN:

NEWPAGE:

PUT (1)5 'STATION NO. DEG MIN DEG MIN ELEV(M) BEG'/;

PETUAN:

RUN;

$1 *$

II 
The following is a listing of the SAS data retrieval program provided on magnetic tape (File 8 on the tape) by CDIAC for reading and printing the station inventory file for the 205-station data sets (File 13 on the tape). The JCL statements (preceded by $/ /$ or $/ *$ ) shown in the following are not provided in the file on the magnetic tape. The JCL statements required will vary for each operating system. The JCL statements shown in the following are provided to illustrate the statements required by an individual at ORNL who has requested these data on a nine-track, $6250 \mathrm{BPI}$, standard-labeled tape with characters written in EBCDIC and who is attempting to read the tape on an IBM mainframe (c.g., IBM 3090).

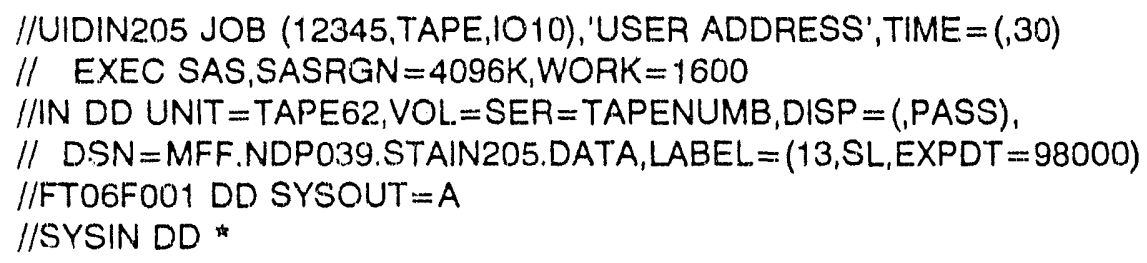

DATA INV205;

INFILE IN:

INPUT SEQNUM 2-4 STNAME \$ 6-25 STANUM 27-31 LATDEG 34-35

LATMIN 37-38 LONDEG 41-43 LONMIN 45-46 ELEV 49-54 TBEGYR 57-60 PBEGYR 63-66;

FILE PRINT NOTITLE HEADER $=$ NEWPAGE:

PUT_INFILE_;

RETUURN;

NEWPAGE:

PUT @6 'STATION' @28 'NO. DEG MIN DEG MIN ELEV(M) TBEG PBEG'/; RETURN:

RUN;

/* 
The following is a listing of the SAS data retrieval program provided on magnetic tape (File 9 on the tape) by CDIAC for reading and printing the 60 -station climate data file (File 14 on the tape). The JCL statements (preceded by // or /*) shown in the following are not provided in the file on the magnetic tape. The JCL statements required will vary for each operaiing system. The JCL statements shown in the following are provided to illustrate the statements required by an individual at ORNL who has requested these data on a nine-track, $6250 \mathrm{BPI}$, standard-labeled tape with characters written in EBCDIC and who is attempting to read the tape on an IBM mainframe (e.g., IBM 3090).

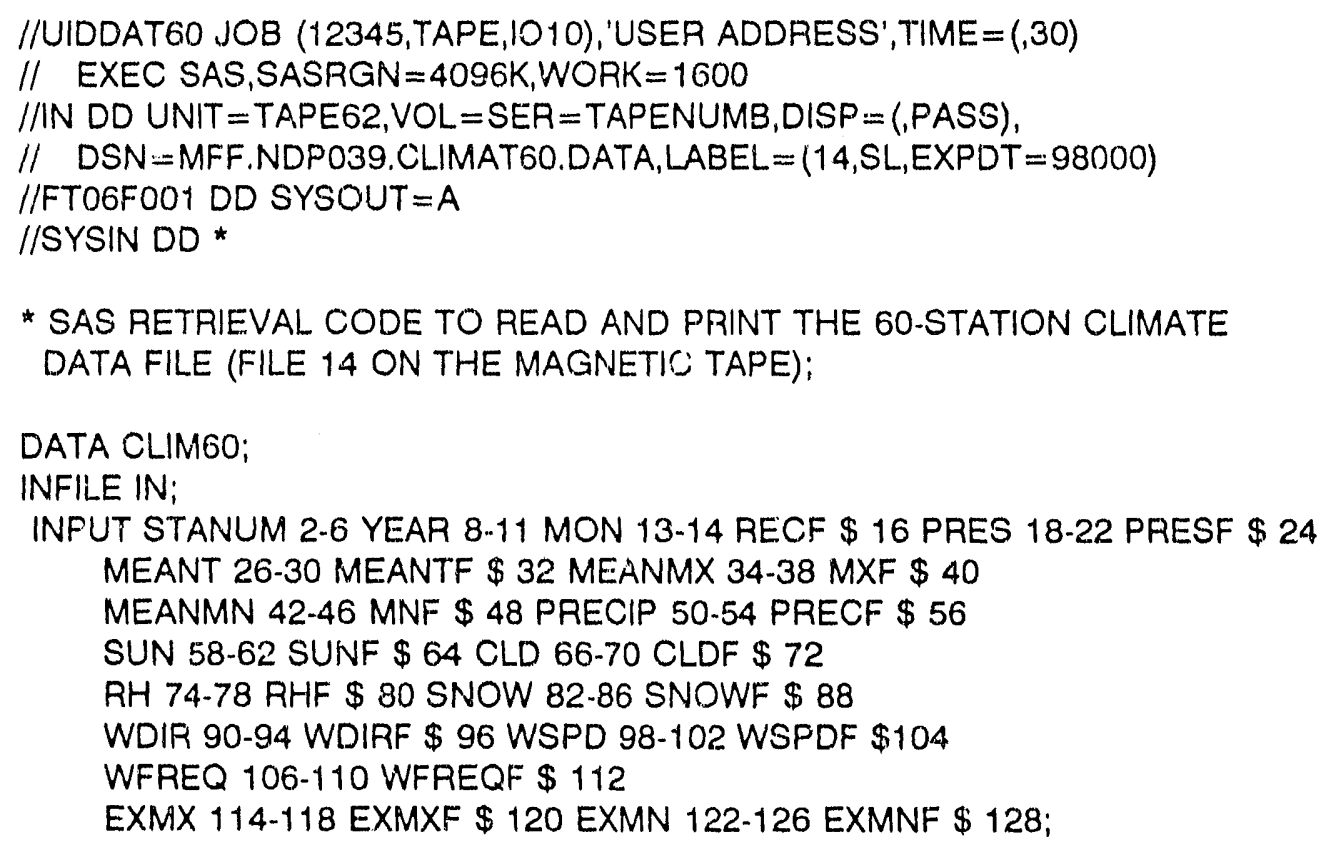

FILE PRINT NOTITLE HEADER = NEWPAGE

PUT INFILE_;

RETURN;

NEWPAGE:

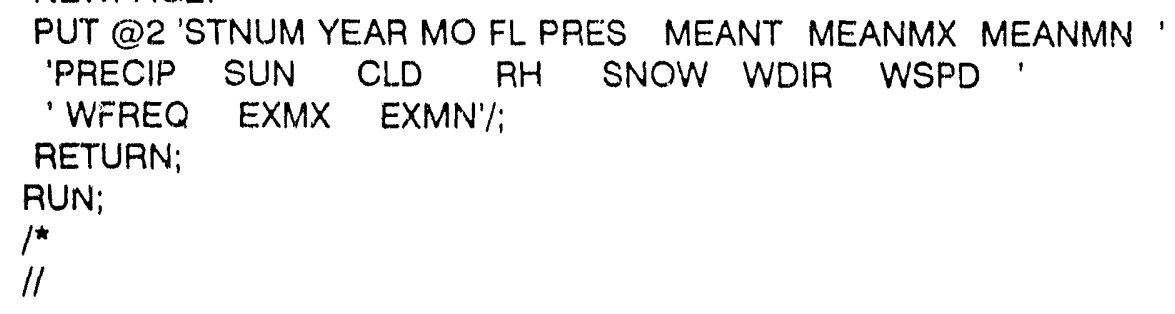


The following is a listing of the SAS data retrieval program provided on magnetic tape (File 10 on the tape) by CDIAC for reading and printing the 205-station monthly mean temperature file (file 15 on the tape). The JCL statements (preceded by $/ /$ or $/{ }^{*}$ ) shown in the following are not provided in the file on the magnetic tape. The JCL statements required will vary for each operating system. The JCL statements shown in the following are provided to illustrate the statements required by an individual at ORNL who has requested these data on a nine-track, $6250 \mathrm{BPl}$, standard-labeled ape with characters writter in EBCDIC and who is attempting to read the tape on an IBM mainframe (e.g., IBM 309()).

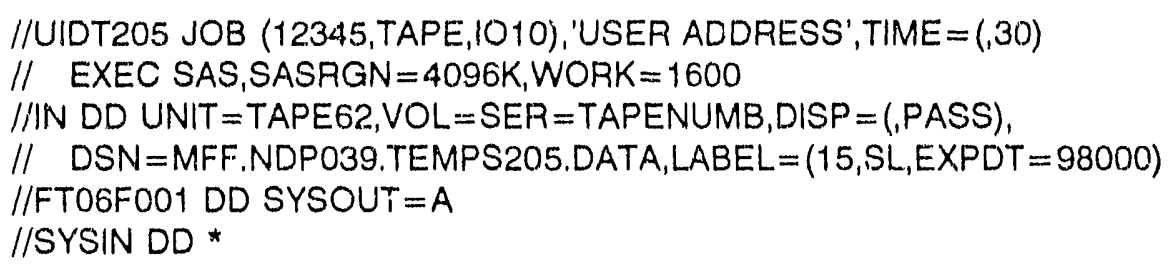

* SAS retrieval CODE to REAd AND PRINT THE 205-STATION MONTHLY MEAN TEMPERATURE FILE (FILE 15 ON THE MAGNETIC TAPE);

DATA TEMP205;

INFILE IN;

INPUT STANUMN" 2-6 YEAR 9-12 RFLAG \$ 14

JAN 16-20 JANFL \$ 22 FEB 24-28 FEBFL \$ 30 MAR 32-36 MARFL \$ 38

APR 40-44 APRFL \$ 46 MAY 48-52 MAYFL \$ 54 JUN 56-60 JUNFL \$ 62

JUL 64-68 JULFL \$ 70 AUG 72-76 AUGFL $\$ 78$ SEP 80-84 SEPFL $\$ 86$

OCT 88-92 OCTFL \$ 94 NOV 96-100 NOVFL \$ DEC 104-108 DECFL \$110;

FILE PRINT NOTITLE HEADER=NEWPAGE;

PUT INFILE;

RETUEAR:

NEWPAGE:

PUT@2 'STNUM YEAR FL JAN FE3 MAR APR MAY' RETURN;

RUN;

$/$ *

11 
The following is a listing of the SAS data retrieval program provided on magnetic tape (File 11 on the tape) by CDIAC for reading and printing the 205-station monthly precipitation life (File 16 on the tape). The JCL statements (preceded by // or /*) shown in the following are not provided in the file on the magnetic tape. The JCL statements required will vary for each operating system. The JCL statements shown in the following are provided to illustrate the statements required by an individual at ORNL who has requested these data on a nine-lrack, 6250 BPI, standard-labeled tape with characters written in EBCDIC and who is attempling to read the tape on an IBM mainframe (e.g., IBM 309()).

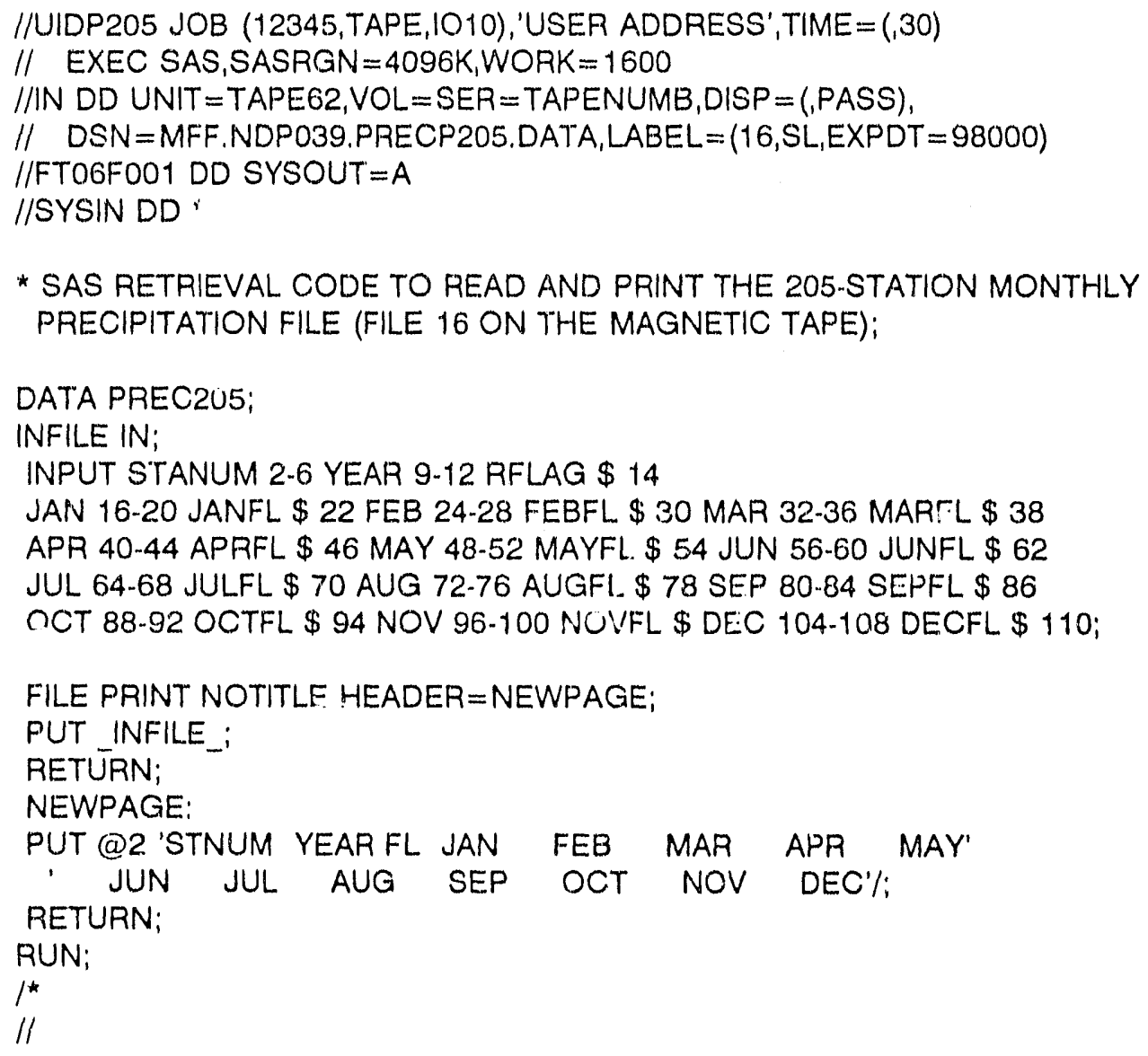




\section{VERIFICATION OF DATA TRANSPORT}

The five data files described herein may be read using the FORTRAN or SAS input/output routines provided. Users should verify that the files have been correctly transported to their systems by generating some or all of the statistics presented in Tables 8-12. These statistics were generated in SAS (PROC MEANS) but can be duplicated in other statistical packages or languages. If the statistics gencrated by the user differ from those presented here, the files may have been corrupted in transport.

These statistics are presented only as a tool to ensure proper reading of the data files. They are not to be construed as either a summary of the PRC climate data or an indicator of trends in these data. 
Table 8. Characteristics of numeric variables from the 60-station inventory file (File 12)

\begin{tabular}{|c|c|c|c|c|}
\hline Variable & $\begin{array}{l}\text { Number of } \\
\text { observations }\end{array}$ & $\begin{array}{l}\text { Mean } \\
\text { value }\end{array}$ & $\begin{array}{l}\text { Minimum } \\
\text { value }\end{array}$ & $\begin{array}{l}\text { Maxinum } \\
\text { value }\end{array}$ \\
\hline SEQNUM & 60 & $30.46,000$ & $1.00(0000$ & 60.0000000 \\
\hline STANUM & 60 & 55840.33333 & 50527.000000 & 59758.0000000 \\
\hline LATDEG & 60 & 33.416667 & 20.0000000 & 49.0000000 \\
\hline LATMIN & 60 & 30.433333 & 1.000000 & 58.0000000 \\
\hline LONDEG & 60 & 111.716667 & 81.000000 & 129.000000 \\
\hline LONMIN & 60 & 28.5333333 & 1.000000 & 59.000000 \\
\hline ELEV & 60 & 501.736667 & 1.200000 & 3658.000000 \\
\hline BEGYR & 60 & 1913.233333 & 1841.000000 & 1951.000000 \\
\hline
\end{tabular}


Table 9. Characteristics of numeric variables from the 205-station inventory file (File 13)

\begin{tabular}{lcrrr}
\hline Variable & $\begin{array}{c}\text { Number of } \\
\text { observations }\end{array}$ & \multicolumn{1}{c}{$\begin{array}{c}\text { Mean } \\
\text { value }\end{array}$} & $\begin{array}{c}\text { Minimum } \\
\text { value }\end{array}$ & \multicolumn{1}{c}{$\begin{array}{c}\text { Maximum } \\
\text { value }\end{array}$} \\
\hline SEQNUM & 205 & 103.00000 & 1.000000 & 205.000000 \\
STANUM & 205 & 55398.770732 & 50136.000000 & 59855.000000 \\
LATDEG & 205 & 34.156098 & 19.000000 & 53.000000 \\
LATMIN & 205 & 30.180488 & 0.000000 & 59.000000 \\
LONDEG & 205 & 109.273171 & 75.000000 & 131.000000 \\
LONMIN & 205 & 28.775610 & 0.000000 & 59.000000 \\
ELEV & 205 & 875.800000 & 1.300000 & 4728.000000 \\
TBEGYR & 205 & 1944.243902 & 1907.000000 & 1961.000000 \\
PBEGYR & 205 & 1944.609756 & 1880.000000 & 1961.000000 \\
\hline
\end{tabular}


80

Table 10. Characteristics of numeric variables from the 60-station climate data file (File 14)

\begin{tabular}{|c|c|c|c|c|}
\hline Variable & $\begin{array}{l}\text { Number of } \\
\text { observations }\end{array}$ & $\begin{array}{l}\text { Mean } \\
\text { value }\end{array}$ & $\begin{array}{l}\text { Minimum } \\
\text { value }\end{array}$ & $\begin{array}{l}\text { Maximum } \\
\text { value }\end{array}$ \\
\hline STANUM & 50521 & 56133.637101 & $50527.00(0)(000)$ & 59758.000000 \\
\hline YEAR & 50521 & 1948.734091 & 1841.0000000 & 1988.0000000 \\
\hline MON & 50521 & 6.509155 & 1.0000000 & $12.00000(0)$ \\
\hline PRES & 50521 & 4720.056867 & -9999.0000000 & 10360.0000000 \\
\hline MEANT & 5() 521 & -1048.202787 & -9999.0000000 & 328.0000000 \\
\hline MEANMX & 5() 521 & -1604.397063 & -9999.000000 & 395.000000 \\
\hline MEANMN & 50521 & -1660.756299 & -9999.0000000 & 280.000000 \\
\hline PRECIP & 50521 & 398.641753 & -9999.000000 & 10.318 .000000 \\
\hline SUN & 50521 & -1852.183924 & -9999.000000 & 3906.0000000 \\
\hline CLD & 50521 & -3063.088241 & -9999.000000 & $1000.0000(0)$ \\
\hline RH & 50521 & -1630.216187 & $-9999.000000)$ & $990.000000)$ \\
\hline SNOW & 50521 & .3290 .252390 & -9999.0000000 & 310.000000 \\
\hline WDIR & 50521 & -3432.722551 & -9999.000000 & 3600.000000 \\
\hline WSPD & 50521 & -2458.855169 & -9999.000000 & 94.0000000 \\
\hline WFREQ & 50521 & -4941.773500 & -9999.000000 & 940.000000 \\
\hline EXMX & 50521 & .9268 .719107 & -9999.000000 & 432.0000000 \\
\hline EXMN & 50521 & -9284.591200 & -9999.000000 & 244.000000 \\
\hline
\end{tabular}


81

Table 11. Characteristics of numeric variables from the 205-station monthly mean temperature file (File 15)

\begin{tabular}{|c|c|c|c|c|}
\hline Variable & $\begin{array}{l}\text { Number of } \\
\text { observations }\end{array}$ & $\begin{array}{l}\text { Mean } \\
\text { value }\end{array}$ & $\begin{array}{l}\text { Minimum } \\
\text { value }\end{array}$ & $\begin{array}{l}\text { Maximum } \\
\text { value }\end{array}$ \\
\hline STANUM & 9155 & 55468.011906 & 501.36 .0000000 & $59855.0(00)(00)$ \\
\hline YEAR & 9155 & 1964.746696 & $1907.000000)$ & 1988.0000000 \\
\hline JAN & 9155 & -1002.653960 & -9999.000000 & 208.000000 \\
\hline FEB & 9155 & -965.259421 & .9999 .000000 & 225.0000000 \\
\hline MAR & 9155 & .906 .209285 & -9999.000000 & 2.51 .0000000 \\
\hline APR & 9155 & -839.558493 & -9999.000000 & 268.0000000 \\
\hline MAY & 9155 & -792.198143 & -9999.000000 & 370.0000000 \\
\hline JUN & 9155 & .764 .451338 & -9999.000000 & 3.32 .0000000 \\
\hline JUL & 9155 & .753 .769416 & -9999.0000000 & 360.000000 \\
\hline AUS & 9155 & -765.309011 & .9999 .0000000 & 371.0000000 \\
\hline SEP & 9155 & .795 .136210 & -9999.000000 & $319.000000)$ \\
\hline OCT & 9155 & -852.265647 & .9099 .000000 & $305.0(0) 0000$ \\
\hline NOV & 9155 & -928.904533 & -9999.000000 & $286.0(0) 0000$ \\
\hline $\mathrm{DEC}$ & 9155 & -989.643474 & $-9999.000000)$ & 228.0000000 \\
\hline
\end{tabular}


Table 12. Characteriolies of numeric variables from the 20)5-station monthly total precipitation file (File 16)

\begin{tabular}{|c|c|c|c|c|}
\hline Variable & $\begin{array}{c}\text { Number of } \\
\text { observations }\end{array}$ & $\begin{array}{l}\text { Mean } \\
\text { value }\end{array}$ & $\begin{array}{l}\text { Minimum } \\
\text { value }\end{array}$ & $\begin{array}{l}\text { Muximum } \\
\text { value }\end{array}$ \\
\hline STANUM & 9086 & 55481.342945 & $50136.000(0)(00)$ & $59855.00(0) 000$ \\
\hline YEAR & 9086 & 1963.914484 & 1880.0000000 & $1988.00(0)(0)()$ \\
\hline JAN & 9086 & -800.750165 & $-9999.000(0)(0)$ & 2685.0000000 \\
\hline FEB & 9086 & -726.452124 & -9999.0000000 & $5(167.0000000)$ \\
\hline MAR & 9086 & -574.599384 & $.9999 .0000000)$ & $6.377 .000(0)(0)$ \\
\hline APR & 9086 & -350.912063 & .9999 .0000000 & 6921.0000000 \\
\hline MAY & 9086 & .72 .017389 & -9999.0000000 & 8262.0000000 \\
\hline JUN & 9086 & 168.092450 & -9999.0000000 & 11412.0000000 \\
\hline JUL & 9086 & 375.360225 & .9999 .000000 & 9319.000000 \\
\hline AUG & 9086 & 255.803324 & $-9999.000(000$ & 9040.0000000 \\
\hline SEP & 9086 & -154.390931 & $-9999 .(000000$ & 9200.000000 \\
\hline $\mathrm{OCI}$ & 9086 & -482.246753 & .9999 .000000 & 8115.000000 \\
\hline NOV & 9086 & -690.477108 & -9999.000000 & 8059.000000 \\
\hline DEC & 9086 & -809.260511 & -9999.000000 & 2496.0000000 \\
\hline
\end{tabular}




\section{APPENDICES}


APPENDIX A

INSTRUMENTA'TION AND DATA COLLECIION METHODS

OF STATIONS IN THE PRC 6()-STA'TION CLIMATE NETWORK 


\section{BAROMETRIC PRISSSURE}

Fortin and Kew-patlern baromelers and an anerold barograph are employed. Thoy are positioned in observation rooms 10 decrease temperature varlability. 'The two instruments are positioned near each other, away from doors and windows, and are culibrated at regular intervals.

Stalicon pressures are recorded in millibars, with monthly means being calculated from daily means and reported to the nearest tenth of a millibar. Mercury column heights, expressed in millimelers, had been reported before 1953 for some stalions, but they have been converted to millibars. Since 1950, readings have boen corrected and redueed for lemperature effects, instrumental error, and gravity error (including latilude and altitude elfects). Readlings were not corrected for gravity eflects prlor to 1950).

\section{TEMPERA'TURE}

Dry- and wet-bulb thermometers are fixed together in an listrument shelter. The standard bulb helghts used prior to 1950 are not known. For the period 1954-1960) the standard height was $2 \mathrm{~m}$. The standard height used since 1961 lis $1.5 \mathrm{~m}$, as it was lor the period 1950-1953. Observing times have varied over the years. The observing limes for each station prior to 1950, along with details on which observations were used in calculating the daily mean, may be found in the accompanying station histories (Appendix B). Since 1950, observations have heen made using Local Standard Time (LST) (1951-1953), Local Mean Solar Time (LMST) (1954-July 1960), and Beijing 'Time (B'T) (August 1960)-present).

Maximum and minimum thermometers are laid horizontally in the same shelter, 3 and $2 \mathrm{~cm}$ higher, respectively, than the dry- and wet-bulb thermometers. Prior to 1951, observation and adjustment were performed at 2000 BT, but since 1951 have taken place at 200) L.ST.

\section{REIA'TTVE HUMIDITY}

A ventilated psychrometer and hair hygrometer (models not given) are housed in separate shelters. Readings from each instrument are translated into relative humidities via their respective tables or charts. Temperature observations are made simultaneously. Circa 1953, certain stations (not identified) used a different humidity table which resulted in crrurs of $1-2 \%$.

\section{PRECIPITATION}

A Dines tilting-siphon rain gauge and a siphon rainlall recorder are used. Observation times prior to 1950 are not known. Sine then, observations have been taken at midnight LST (1951-1953), 1900 LMST (1954-July 1960), and 200() B'T' 
(Auguat 196(1)present). Observed lotals may fnclude llyuld precipltallon, liquid equivalont of solid preceipitation or liost, dew, or fog. Amounts less than 0,65 $\mathrm{mm}$ are recorded as zero,

\section{SUNSIINE DURATTION}

Pritor to 1954, a Jordan Photographic Sunshine Recorder was used, and since 1954 a Camphell-Stokes Sunshine Recorder has been used. CAS stutes that some monthly sunshine durations have been estlmated, but these entries have not been flagged or documented.

\section{CLOUD AMOUN'T}

Cloud amount has been estimated in tenths of' sky cover by observers. Zero indicales clear skies; 10 indicates overcast skies. Monthly mean cloud amounts are obtained from averaging mean dally amounts for the month, multiplying by 10 to obtain a pereentage, and rounding this value to the nearest whole pereent. CAS states the data contain many estimales, but, as with the sunshine data, these have not been identilied via lligging or documentation.

\section{WIND DATA}

Since 1954, an EL electric wind direction and speed device and a Dines wind direction and speed recorder have been used. Recelvers for wind instruments are mounted on a pole $10-12 \mathrm{~m}$ above ground level. The type of instrument used before 1954 is unclear, but at the following stations the Beaulort Scale was employed:

ZhangYe (52652)

LanZhou (52889)

YanTai (54765)

LaSa (55591)

TengChong (56739)

TianShui (57006)

ZhengZhou (57083)

YiChang (57461)

ChangSha (57679)

GuiYang (57816)

AnQing (58424)

WenZhou (58659)

FuZhou (58847)

XiaMen (59134)

WuZhou (59265)

ShanTou (59316)

Haikou (59758) 


\section{A-5}

The Beaufort Scale entries from these stations have been converted to $\mathrm{m} / \mathrm{s}$.

Observation times used in calculating the daily mean are unclear for the period prior to 1951. Several different time groups were used over the period 1951-1953 (Appendix B). For the period 1954-July 1960, observations from $0100,0700,1300$ and 1900 were used (assumably LMST), and since August 1960, observations from 0200, 0800, 1400, and 2000 have been used (assumiably BT). Wind direction is recorded in $22.5^{\circ}$ increments of azimuth clockwise from north (sixtcen directions), with $0^{\circ}$ indicating calm winds and $360^{\circ}$ indicating a north wind. The monthly dominant wind direction is simply the most frequent wind direction observed during the month, and its frequency (percentage of the time it was observed) is the dominant wind frequency. 


\section{APPENDIX B}

STATION HISTORIES OF THE PRC 60-STATION CLIMATE NETWORK

Data source codes in each station history correspond to the numbered data sources in Appendix C. 
B-3

No. 150527 日ai La Er

A. Main Data Sourcos

$\begin{array}{ll}\text { 1. } 1909.1-1950.12 & (16) \\ 1909-1930 \text { ('Total amount of cloud) } & (14) \\ \text { 2. } 1951.1-1960.12 & (17) \\ \text { 3. } 1961.1-1980.12 & (18)(6)(7)(8)(9)(10)(11) \\ \text { 4. } 1981-1983 & (13) \\ \text { 5. } 1961-1970 \text { (The wean pressure is taken from) } & (157)\end{array}$

B. Location of Station, TImo Standard and IImes of Observation

\begin{tabular}{|c|c|c|c|c|c|c|}
\hline $\begin{array}{c}\text { Observational } \\
\text { period }\end{array}$ & Address & $\left|\begin{array}{l}\text { Location } \\
\text { Lat.N }\end{array}\right|$ & $\left|\begin{array}{l}\text { of stat } \\
\text { LoN.E }\end{array}\right|$ & $\left.\right|_{\mathrm{B}} ^{10 \mathrm{~B}}(\mathrm{M})(\mathrm{PH})$ & $\begin{array}{l}\text { Time Zone } \\
\text { system }\end{array}$ & $\begin{array}{c}\text { Times of } \\
\text { observation: }\end{array}$ \\
\hline $1909.1-1932$ & & $49^{\circ} 14^{\prime} \mid$ & $119^{\circ} 43^{\circ}$ & 609.7 & $126^{\circ} 30^{\prime} \mathrm{E}$ & $3(7,13,21)$ \\
\hline $1935-1936$ & & $49^{\circ} 13^{\prime}$ & $119^{\circ} 44^{\prime}$ & 619.0 & $120^{\circ}$ E.M.I & $\begin{array}{c}6(2,6,10 \\
14,18,22)\end{array}$ \\
\hline $1937-1942$ & & $49^{\circ} 13^{\prime}$ & $119^{\circ} 44^{\circ}$ & 619.0 & $135^{\circ}$ E.M.T & $\begin{array}{l}6(2,6,10) \\
\quad 14,18,22)\end{array}$ \\
\hline $1950.1-12$. & $\begin{array}{c}\text { Dong Shan } \\
\text { atrport }\end{array}$ & $49^{\circ} 13^{\prime}$ & $119^{\circ} 45^{\prime}$ & 676.6 & $120^{\circ}$ E.M.T & $\begin{array}{l}8(3,6,9,12) \\
14,18,21,24)\end{array}$ \\
\hline $\begin{array}{l}1952.1-12 \\
1954.10\end{array}$ & $\begin{array}{l}\text { As above } \\
\text { As above }\end{array}$ & $\begin{array}{ll}49^{\circ} & 13^{\circ} \\
49^{\circ} & 13^{\circ}\end{array}$ & $\begin{array}{l}119^{\circ} 45^{\prime} \\
119^{\circ} 45^{\prime}\end{array}$ & $\begin{array}{l}676.6 \\
676.6\end{array}$ & $\begin{array}{l}120^{\circ} \text { E.M.I } \\
\text { Local mean } \\
\text { solar time }\end{array}$ & $\begin{array}{l}24(1-24) \\
4(1,7,13,19)\end{array}$ \\
\hline $1954.11-12$ & A. above & $49^{\circ} 13^{\prime}$ & $119^{\circ} 45^{\prime}$ & 676.8 & $\begin{array}{l}\text { Local mean } \\
\text { solar tima }\end{array}$ & $4(1,7,13,19)$ \\
\hline $1956.1-1960.7$ & $\begin{array}{c}\text { East-rivar } \\
\text { district } \\
\text { (1n city) }\end{array}$ & $49^{\circ} 13^{\prime}$ & $119^{\circ} 45^{\prime}$ & 612.9 & $\begin{array}{l}\text { Local mean } \\
\text { solar time }\end{array}$ & $4(1,7,13,19)$ \\
\hline $\begin{array}{l}1960.8-1976.3 \\
1976.4-1983\end{array}$ & $\begin{array}{l}\text { As above } \\
\text { As above }\end{array}$ & $\begin{array}{l}49^{\circ} 13^{\prime} \\
49^{\circ} 13^{\prime}\end{array}$ & $\mid \begin{array}{l}119^{\circ} 45^{\prime} \\
119^{\circ} \\
45^{\prime}\end{array}$ & $\mid \begin{array}{l}612.9 \\
612.8\end{array}$ & $\begin{array}{l}120^{\circ} \text { E.M.T } \\
120^{\circ} \text { E.M.T }\end{array}$ & $\mid \begin{array}{l}4(2,8,14,20) \\
4(2,8,14,20)\end{array}$ \\
\hline
\end{tabular}

C. Number of Observations Used for Calculating the Dally Mean

\begin{tabular}{|c|c|c|c|c|}
\hline Hean times & $\begin{array}{c}\text { Mean pressure } \\
\text { (Pariod) }\end{array}$ & $\begin{array}{l}\text { Temperature } \\
\text { (Period) }\end{array}$ & $\begin{array}{l}\text { Relative humldity } \\
\text { (Poriod) }\end{array}$ & $\begin{array}{l}\text { Wind } \\
\text { (Portod) }\end{array}$ \\
\hline $\begin{array}{l}3(7,13,21) \\
6(2,6,20\end{array}$ & $1909-1932$ & $1909-1932$ & $\ldots$ & \\
\hline $14,18,22)$ & $1935-1941.1950$ & $\begin{array}{l}1935-1942 \\
1950\end{array}$ & $\begin{aligned} 1935- & 1942 \\
& 1950(3-12)\end{aligned}$ & \\
\hline $\begin{array}{l}14,18,21,24) \\
24(1-24) \\
4(1,7,23,19) \\
4(2,8,14,20)\end{array}$ & $\begin{array}{l}1951 \\
1952-1953 \\
1954.1-1960.7 \\
1960.8-1983\end{array}$ & $\begin{array}{l}1951 \\
1952-1953 \\
1954.1-1960.7 \\
2960.8-1983\end{array}$ & $\begin{array}{l}1951 \\
1952-1953 \\
1954.1-1960.7 \\
2960.8-1983\end{array}$ & $\left|\begin{array}{l}1951 \\
1954.1-1960.7 \\
1960.8-1983\end{array}\right|$ \\
\hline
\end{tabular}

D. Remarks:

1.01d-name:" Hu Lun " 


\section{B-4}

A. Nain Data Sourcos

$\begin{array}{lr}\text { 1. } 1939-1950 & (19) \\ \text { 2. } 1951-1980 & (20) \\ \text { 3. } 1971-1980 & (159) \\ \text { 4. } 1981-1983 & (13) \\ \text { 5. } 1951-62 \text { (Moan meximum and minimum temperatura) } & (12) \\ 1963-70 & (156) \\ 1971-80 & (159)\end{array}$

B. Location of Station, Time Standard and Times of Observation

\begin{tabular}{|c|c|c|c|c|c|c|}
\hline $\begin{array}{c}\text { Observational } \\
\text { perlod }\end{array}$ & Address & $\begin{array}{l}\text { Locatio } \\
\text { Lat.N }\end{array}$ & $\left|\begin{array}{l}\text { of stat } \\
\text { LON.E }\end{array}\right|$ & $\left.\right|^{10 n} \mathrm{~B}(\mathrm{M})(\mathrm{PH})$ & $\begin{array}{c}\text { Time zone } \\
\text { systeon }\end{array}$ & $\begin{array}{c}\text { Tlowe of } \\
\text { observations }\end{array}$ \\
\hline $1939-1945$ & & $49^{\circ} 10^{\prime}$ & $125^{\circ} 13^{\prime}$ & $\begin{array}{l}222.3 \\
(223.7)\end{array}$ & $135^{\circ}$ E.M.I & \\
\hline 1949.8 & $\begin{array}{c}\text { Nen j1ang } \\
\text { (town) }\end{array}$ & $49^{\circ} 10^{\prime}$ & $125^{\circ} 13^{\prime}$ & $\begin{array}{r}222.3 \\
(223.7)\end{array}$ & $120^{\circ}$ E.M.I & $\begin{array}{r}5(6,10,14 \\
18,22)\end{array}$ \\
\hline $1949,9,1950$ & $(1 a$ city $)$ & $49^{\circ} 10^{\prime}$ & $125^{\circ} 13^{\prime}$ & $\begin{array}{l}222.3 \\
(223.7)\end{array}$ & $120^{\circ}$ E.M.T & $4(6,10,14,18)$ \\
\hline 1951 & $\begin{array}{c}x \ln \text { 日ua } \\
\text { stroot }\end{array}$ & $49^{\circ} 10^{\prime}$ & $125^{\circ} 13^{\prime}$ & $\begin{array}{l}222.3 \\
(223.7)\end{array}$ & $120^{\circ}$ E.M.I & $\mid \begin{array}{c}6(2,6,10,14, \\
18,22)\end{array}$ \\
\hline $1952-53$ & As above & $49^{\circ} 10^{\prime}$ & $125^{\circ} 13^{\prime}$ & $\begin{array}{l}222.3 \\
(223.7)\end{array}$ & $\begin{array}{l}\text { Local mean } \\
\text { solar time }\end{array}$ & $\left(\begin{array}{l}8(3,6,9,12 \\
14,18,21,24)\end{array}\right.$ \\
\hline $1954.1-60.6$ & As above & $49^{\circ} 10^{\prime}$ & $125^{\circ} 13^{\prime}$ & $\begin{array}{l}222.3 \\
(223.7)\end{array}$ & $120^{\circ}$ E.M.I & $24(1-24)$ \\
\hline $1960.7-1972.5$ & Ass above & $49^{\circ} 10^{\prime}$ & $125^{\circ} 13^{\prime}$ & $\begin{array}{r}222.3 \\
(223.7)\end{array}$ & $120^{\circ}$ E.M.I & $4(2,8,14,20)$ \\
\hline 1972.t,-NoW & $\begin{array}{l}\text { Southern } \\
\text { suburb }\end{array}$ & $49^{\circ} 10^{\prime}$ & $225^{\circ} 14^{\prime}$ & 242.2 & $120^{\circ}$ E.M.T & \\
\hline
\end{tabular}

C. Number of Observations isod for Calculating, the Dally Mean

\begin{tabular}{|c|c|c|c|c|}
\hline Mean times & $\begin{array}{c}\text { Moan pressura } \\
\text { (Poriod) }\end{array}$ & $\begin{array}{l}\text { Temporature } \\
\text { (Period) }\end{array}$ & $\left|\begin{array}{c}\text { Rolative humidity } \\
\text { (Poriod) }\end{array}\right|$ & $\begin{array}{l}\text { Cloud } \\
\text { (Poriod) }\end{array}$ \\
\hline $\begin{array}{l}6(2,6,10,14 \\
18,22) \\
5(6,10,14,18, \\
22) \\
8(3,6,9,12\end{array}$ & $\mid \begin{array}{l}1939-1945.7 \\
1949.9-1950\end{array}$ & $\begin{array}{l}1939-1945.7 \\
1949.9-1950\end{array}$ & $\begin{array}{l}1939-1945.7 \\
1949.9-1950\end{array}$ & $\begin{array}{l}1939.9-1945.7 \\
1939-1945.7\end{array}$ \\
\hline $\begin{array}{l}14,18,21,24) \\
24(1-24) \\
4(1,7,23,19) \\
4(2,8,14,20)\end{array}$ & $\begin{array}{l}1951 \\
1952-1953 \\
1954.1-1960.6 \\
12960.7-1983\end{array}$ & $\begin{array}{l}1951 \\
1952-1953 \\
1954.1-1960.6 \\
1960.7-1983\end{array}$ & $\begin{array}{l}1951 \\
1952-1953 \\
1954.1-1960.6 \\
1960.7-1983\end{array}$ & $\begin{array}{l}1951 \\
1952-1953 \\
1954.1-1960.6 \\
1960.7-1983\end{array}$ \\
\hline
\end{tabular}

D. Remarks : 


\section{B-5}

No. 350632 Bo Ke Tu

A. Main Data Sourcos

$\begin{array}{lr}\text { 1. } 1914-1950 & (21) \\ \text { 2. } 1914-1932 & (15) \\ \text { 3. } 1951-1960 & (22) \\ \text { 4. } 1971-1980 & (160) \\ \text { 5. } 1981-1983 & (13)\end{array}$

B. Looation of Station, IIme Standard and Times of Observation

\begin{tabular}{|c|c|c|c|c|c|c|}
\hline $\begin{array}{c}\text { Observational } \\
\text { period }\end{array}$ & Address & $\left|\begin{array}{l}\text { Loontion } \\
\text { Lat.N }\end{array}\right|$ & $\left\{\begin{array}{l}\text { of stat: } \\
\text { LoN. }\end{array}\right.$ & $\begin{array}{l}\text { for } \\
\mid \mathrm{B}(\mathrm{M})(\mathrm{PB})\end{array}$ & $\begin{array}{l}\text { Sime zon } \\
\text { system }\end{array}$ & $\begin{array}{c}\text { TImes of } \\
\text { observations }\end{array}$ \\
\hline $1911-1932$ & & $48^{\circ} 46^{\prime} \mid$ & $\left|121^{\circ} 55^{\prime}\right|$ & 698.8 & $126^{\circ} 30^{\prime}$ & $3(7,13,21)$ \\
\hline $1951.1-10$ & $\begin{array}{l}\text { Northern mo- } \\
\text { untnin Kan, ( } \\
\text { countryside) }\end{array}$ & $48^{\circ} 46^{\prime}$ & $121^{\circ} 55^{\prime}$ & $\cdots$ & $120^{\circ}$ E.M.T & $\begin{array}{r}8(3,6,9,12 \\
14,18,21,24)\end{array}$ \\
\hline $1951.11-12$ & $\begin{array}{l}2500 \mathrm{M} \text { away } \\
\text { from the old } \\
\text { addros: }\end{array}$ & $48^{\circ} 46^{\prime}$ & $121^{\circ} 55^{\prime}$ & 738.7 & $120^{\circ}$ E.M.T & $\begin{array}{r}8(3,6,9,12 \\
14,28,21,24)\end{array}$ \\
\hline $\begin{array}{l}1952.1-1953.12 \\
1954.1-1960.7\end{array}$ & $\begin{array}{l}\text { As above } \\
\text { As above }\end{array}$ & $\left|\begin{array}{ll}48^{\circ} & 46^{\prime} \\
48^{\circ} & 66^{\prime}\end{array}\right|$ & $\mid \begin{array}{ll}121^{\circ} & 55^{\prime} \\
121^{\circ} & 55^{\prime}\end{array}$ & $\begin{array}{l}738.7 \\
738.7\end{array}$ & $\begin{array}{l}120^{\circ} \text { E.M.I } \\
\text { Local moan } \\
\text { solar timo }\end{array}$ & $\begin{array}{l}24(1-24) \\
4(1,7,13,19)\end{array}$ \\
\hline $\begin{array}{l}1960.8-1960.12 \\
1961.1-1970.12\end{array}$ & $\begin{array}{l}\text { As above } \\
\text { As abovo }\end{array}$ & $\begin{array}{ll}48^{\circ} & 46^{\prime} \\
48^{\circ} & 46^{\prime}\end{array}$ & $\begin{array}{l}121^{\circ} 55^{\prime} \\
121^{\circ} 55^{\prime}\end{array}$ & $\begin{array}{l}738.7 \\
738.7\end{array}$ & $\begin{array}{c}120^{\circ} \text { E.M.I } \\
\text { (B०1Jing } \\
\text { tiog) }\end{array}$ & $\begin{array}{l}4(2,8,14,20) \\
4(2,8,14,20)\end{array}$ \\
\hline 1971.1-now & As above & $48^{\circ} 46^{\prime}$ & $121^{\circ} 55^{\prime}$ & 739.4 & $\begin{array}{c}\left(B \bullet 1 J 1 g_{8}\right. \\
t \perp \infty \theta)\end{array}$ & $4(2,8,14,20)$ \\
\hline
\end{tabular}

C. Number of Observations Usod for Calculating the Dally Mean

\begin{tabular}{|c|c|c|c|c|}
\hline Moan times & $\begin{array}{c}\text { Menon preseure } \\
\text { (Poriod) }\end{array}$ & $\begin{array}{c}\text { Temperature } \\
\text { (Perlod) }\end{array}$ & $\mid \begin{array}{l}\text { Relative humidity } \\
\text { (Foriod) }\end{array}$ & $\begin{array}{l}\text { Wind } \\
\text { (Poriod) }\end{array}$ \\
\hline $\begin{array}{l}3(7,13,21) \\
8(3,6,9,12, \\
14,18,21,24) \\
24(1-24) \\
4(1,7,13,19) \\
4(2,8,14,20)\end{array}$ & $\begin{array}{l}1915-1932 \\
-1 \\
1952-1953 \\
1954.1-1960.7 \\
2960.8-\text { now }\end{array}$ & $\begin{array}{l}1914-1932 \\
1951 \\
1952-1953 \\
1954.1-1960.7 \\
1960.8-n 0 w\end{array}$ & $\begin{array}{l}1 \\
1951 \\
1952-1953 \\
1954.1-1960.7 \\
1960.7-\text { now }\end{array}$ & $\begin{array}{l}1951.1-12 \\
1952-1953 \\
1954.1-1960.7 \\
1960.7-\text { now }\end{array}$ \\
\hline
\end{tabular}

D. Remarks :

1. Old-name: 'Gul $\mathrm{Xl}$ Bo Ke Tu". 
No. 450745 Q1 Q1 Ba Er

A. Main Data Sourcoa

$\begin{array}{lr}\text { 1. } 1909-1928 & (1) \\ \text { 2. } 1909-1932 & (3) \\ 1928-1950 & (161) \\ \text { 3. } 1951-1980 & (20) \\ \text { 4. } 1981-1983 & (13) \\ \text { 5. } 1951-1962 \text { (Moan/max/min tamporatura } & \text { and total oloud amount) } \\ & (12) \\ 1963-1970 & (156) \\ 1971-1980 & \text { (159) }\end{array}$

B. Location of Statfou, Time Standard and TImes of Observation

\begin{tabular}{|c|c|c|c|c|c|c|}
\hline $\begin{array}{c}\text { Observational } \\
\text { perlod }\end{array}$ & Addrose & $\left|\begin{array}{l}\text { Looat Lor } \\
\text { Lat.d }\end{array}\right|$ & $\mid \begin{array}{l}n \text { of stat } \\
\text { Los.z }\end{array}$ & $|\mathrm{H}(\mathrm{M})(\mathrm{PB})|$ & $\mid \begin{array}{c}\text { Timon zone } \\
\text { system }\end{array}$ & $\mid \begin{array}{c}\text { Times of } \\
\text { observations }\end{array}$ \\
\hline $1909-1928$ & $\begin{array}{l}\text { In routine } \\
\text { ofetice place } \\
\text { (1n ofty) }\end{array}$ & $\left|47^{\circ} 10^{\prime}\right|$ & $\left|123^{\circ} 49^{\prime}\right|$ & 149.3 & & \\
\hline $\begin{array}{l}1928-1930.4 \\
1930.5-1935 \\
1933 \\
1936-1938 \\
1939-1942.4 \\
1949.6 \\
1949.7-12\end{array}$ & $\begin{array}{l}\text { As above } \\
\text { As above } \\
\text { As above } \\
\text { As above } \\
\text { As above }\end{array}$ & 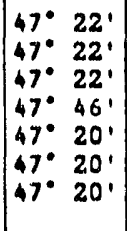 & $\begin{array}{l}123^{\circ} 55^{\prime} \\
123^{\circ} .55 \\
123^{\circ} .55^{\prime} \\
123^{\circ} .55 \\
123^{\circ} .566^{\prime} \\
123^{\circ} 56^{\prime} \\
123^{\circ} 56^{\prime}\end{array}$ & $\begin{array}{l}152.2 \\
152.2 \\
152.2 \\
152.2 \\
147.0 \\
147.0 \\
147.0\end{array}$ & $\begin{array}{l}120^{\circ} \text { E.M.T } \\
139^{\circ} \text { E.M.T } \\
135^{\circ} \text { E.M.T } \\
120^{\circ} \text { E.M.T } \\
120^{\circ} \text { E.M.T } \\
120^{\circ} \text { E.M.T } \\
120^{\circ} \text { E.M.T }\end{array}$ & $\begin{array}{l}1(10) \\
3(5,13,21) \\
3(6,14,22) \\
3(6,14,22) \\
6(2,6,10,14 \\
4(6,10,14,18) \\
6(2,6,10,14 \\
18,22)\end{array}$ \\
\hline 1950 & $\begin{array}{l}\text { No. 1. Moteo- } \\
\text { treot Shang - } \\
\text { fu road }\end{array}$ & $47^{\circ} 20^{\circ}$ & $123^{\circ} 56^{\prime}$ & 147.0 & $120^{\circ}$ E.M.T & $\begin{array}{r}6(2,6,10,14 \\
18,22)\end{array}$ \\
\hline $\begin{array}{l}1951-1952 \\
1953-1960.7\end{array}$ & As bove & $\begin{array}{l}47^{\circ} 20^{\prime} \\
47^{\circ} 20^{\prime}\end{array}$ & $\begin{array}{ll}123^{\circ} & 56^{\prime} \\
123^{\circ} & 56^{\prime}\end{array}$ & $\begin{array}{l}147.0 \\
147.0\end{array}$ & $\begin{array}{l}120^{\circ} \text { E.M.I } \\
\text { Local moan } \\
\text { soler time }\end{array}$ & $\begin{array}{l}24(1-24) \\
4(1,7,13,19)\end{array}$ \\
\hline $1960.8-1963.12$ & As above & $47^{\circ} 20^{\prime}$ & $12.3^{\circ} 56^{\prime}$ & 147.0 & $\begin{array}{c}\text { (Bo1jins } \\
\text { t100) }\end{array}$ & $4(2,8,24,20)$ \\
\hline $1964.1 \times 1983$ & $\begin{array}{l}\text { West-big br- } \\
\text { 1dge-wost } \\
\text { ( 1n o1ty ) }\end{array}$ & $47^{\circ} 23^{\prime}$ & $123^{\circ} 55^{\prime}$ & 145.9 & $\begin{array}{c}(B \in 1, j \text { Ins } \\
\text { time) }\end{array}$ & $4(2,8,14,20)$ \\
\hline
\end{tabular}

C. Number of Obsarvations Uand for Calculating whe Dally Maan

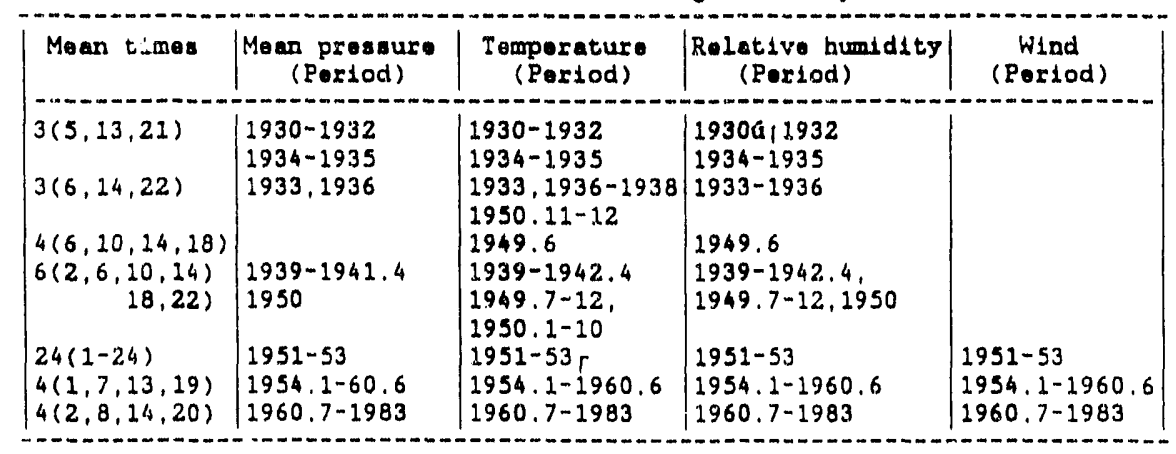

D. Remarks :

1. Old nang: "Long Jlang Ang Ang $X 1 "$ ". 
B-7

No.

A. Matn Data Sources

$\begin{array}{lr}\text { 1. } 1898-1906 & (3) \\ \text { 2. } 1909-1950 & (23) \\ \text { 3. } 1951-1980 & (20) \\ \text { 4. } 1981-1983 & (13) \\ \text { 5. } 1951-1962 & (12) \\ 1971-1980 & (159) \\ 1963-1970 & (156)\end{array}$

B. Location of Station, Time Standard and Times of Observation

\begin{tabular}{|c|c|c|c|c|c|c|}
\hline $\begin{array}{c}\text { Observational } \\
\text { pertiod }\end{array} \mid$ & Addres: & $\begin{array}{l}\text { Locat 1'. } \\
\text { Lat. . }\end{array}$ & $\begin{array}{l}\text { of stat } \\
\text { LoN.E }\end{array}$ & $\begin{array}{l}\text { fon } \\
|\mathrm{g}(\mathrm{M})(\mathrm{PB})|\end{array}$ & Tlme Zone & $\begin{array}{c}\text { Times of } \\
\text { observations }\end{array}$ \\
\hline $\begin{array}{l}1898-1906 \\
1909-1935 \\
1936-1942\end{array}$ & (n) & $\begin{array}{l}45^{\circ} 46^{\prime} \\
45^{\circ} \\
45^{\circ} \\
45^{\circ}\end{array}$ & $\begin{array}{l}126^{\circ} 58^{\prime} \\
126^{\circ} 38^{\prime} \\
126^{\circ} 38^{\prime}\end{array}$ & $\begin{array}{l}147.0 \\
145.1 \\
145.1\end{array}$ & $\begin{array}{l}120^{\circ} \text { E.M.T } \\
135^{\circ} \text { E.M.T }\end{array}$ & $\begin{array}{l}3(3,13,21) \\
6(2,6,10,14 ; \\
18,22)\end{array}$ \\
\hline $1049-1950$ & $\begin{array}{l}\text { Nan Gang bdy } \\
\text { otrajght str- } \\
\text { oot (In olty) }\end{array}$ & $45^{\circ} 45$ & $126^{\circ} 38^{\prime}$ & 145.1 & $120^{\circ}$ E.M.T & $\begin{array}{r}6(2,6,10,14 \\
10,22)\end{array}$ \\
\hline $1951-1953$ & As above & $45^{\circ} 45^{\prime}$ & $126^{\circ} 38^{\prime}$ & 145.1 & $120^{\circ}$ E.M.T & $\begin{array}{c}24(1-24) \\
18,22)\end{array}$ \\
\hline $1954-1960.6$ & $\begin{array}{l}\text { GongBin road, } \\
\text { Xlangtan dis- } \\
\text { trict }\end{array}$ & $45^{\circ} 45^{\prime}$ & $126^{\circ} 46^{\prime}$ & 146.0 & $\begin{array}{l}\text { Looal mean } \\
\text { solar time }\end{array}$ & $4(1,7,13,19)$ \\
\hline $1971.1-1979$ & Xue fu road & $45^{\circ} 41^{\prime}$ & $126^{\circ} 37^{\prime}$ & 171.7 & $\begin{array}{c}(B \in 1 j \operatorname{lng} \\
\operatorname{tin} \theta)\end{array}$ & $4(2,8,14,20)$ \\
\hline $1980-1983$ & $\begin{array}{l}\text { No.47, Eloct- } \\
\text { rlodty-carbon } \\
\text { factory stro- } \\
\text { ot, Gong Bln } \\
\text { road }\end{array}$ & $45^{\circ} 45^{\prime}$ & $126^{\circ} 46^{\prime}$ & 142.3 & $\begin{array}{c}(B \cdot 1 J \operatorname{lng} \\
\operatorname{tim\theta } \theta\end{array}$ & $4(2,8,14,20)$ \\
\hline
\end{tabular}

C. Number of Observations Used for Calculating the Datly Mean

\begin{tabular}{|c|c|c|c|c|c|}
\hline Mean timas & $\mid \begin{array}{c}\text { Moan prossuxo } \\
\text { (Poriod) }\end{array}$ & $\begin{array}{c}\text { Teaperatura } \\
\text { (Parlod) }\end{array}$ & $\begin{array}{l}\text { Rolative } \\
\text { humidity } \\
\text { (Poriod) }\end{array}$ & $\begin{array}{l}\text { Cloud } \\
\text { (Porlod) }\end{array}$ & $\begin{array}{l}\text { Wind } \\
\text { (Pertod) }\end{array}$ \\
\hline $\begin{array}{l}3(5,13,21) \\
6(2,6,10) \\
14,18,22) \\
24(1-24) \\
4(1,7, \\
13,19) \\
4(2,8,\end{array}$ & $\left|\begin{array}{l}1909-1935 \\
1936-1942 \\
1949-1950 \\
1951-1953 \\
1954.1-1960.6 \\
1960.7-1983\end{array}\right|$ & $\begin{array}{l}1909-1935 \\
1936-1942 \\
1949-1950 \\
1951-1953 \\
1954.1-1960.6 \\
1960.7-1983\end{array}$ & $\begin{array}{l}1909-1935 \\
1936-1942 \\
1949-1950 \\
1951-1953 \\
1954.1-1960.6 \\
1960.7-1983\end{array}$ & $\begin{array}{l}1951-1953 \\
1954.1-1960.6\end{array}$ & $\left\{\begin{array}{l}1951-1953 \\
1954.1-1960.6 \\
1960.7-1983\end{array}\right.$ \\
\hline
\end{tabular}

D. Remarks:

1. Old name:" Benjlang". 
A. Main Data Sourcas
1. $1951.8-1980$
2. $1981-1983$
3. 1951,8-12 (Nean temperature, dominant winds and woan wind speed) (12)
1951.9-12 (Procitation)

B. Location of Station, Time Standard and TImes of Observation

\begin{tabular}{|c|c|c|c|c|c|c|c|}
\hline $\begin{array}{c}\text { Observational } \\
\text { period }\end{array}$ & Addres: & $\begin{array}{l}\text { Loce } \\
\text { Lat. }\end{array}$ & $N$ & $\left\{\begin{array}{l}\text { of stat } \\
\text { LoN.E }\end{array}\right.$ & 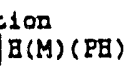 & $\begin{array}{l}\text { Tlme Zone } \\
\text { system }\end{array}$ & $\begin{array}{c}\text { Times of } \\
\text { observations }\end{array}$ \\
\hline $1951.8-1953.12$ & Alrport & $43^{\circ}$ & $55^{\prime}$ & $82^{\circ} 17^{\prime}$ & 670.0 & $\begin{array}{c}(B \cup 1 j \text { Ing } \\
\text { time })\end{array}$ & $\begin{array}{r}8(3,6,9,12,14 \\
18,21,24)\end{array}$ \\
\hline $1954 \cdot 1-12$ & Alrport & $43^{\circ}$ & $55^{1}$ & $82^{\circ} 17^{\prime}$ & 670.0 & $\begin{array}{c}(B) 1 j \text { Lng } \\
t \text { ime })\end{array}$ & $\begin{array}{l}4(4,10,16,22) \\
(3,9,15,21)\end{array}$ \\
\hline $1955.1-1957.9$ & Alrport & $43^{\circ}$ & $55^{1}$ & $81^{\circ} 17^{\prime}$ & 670.0 & $\begin{array}{c}(B \cup 1 j 108 \\
\left.t 1 \mathrm{~m}_{0}\right)\end{array}$ & $4(1,7,13,19)$ \\
\hline 1957.10 & Alrport & $43^{\circ}$ & $57^{1}$ & $82^{\circ} 20^{\prime}$ & 662.5 & $\begin{array}{c}(B \circ j \mathrm{j} \text { ins } \\
\text { time })\end{array}$ & $4(1,7,13,19)$ \\
\hline $1957.11-60.7$ & Alrport & $43^{\circ}$ & $55^{1}$ & $81^{\circ} 171$ & 664.0 & $\begin{array}{c}(B \otimes 1 j \text { Iag } \\
t \text { Ime })\end{array}$ & $4(1,7,13,19)$ \\
\hline $1960.8-61.12$ & Alrport & $43^{\circ}$ & $55^{1}$ & $81^{\circ} 17^{\prime}$ & 663.0 & $\begin{array}{c}(B \circ j f 1 n g \\
t \text { ime })\end{array}$ & $4(2,8,14,2.0)$ \\
\hline $1962-1983$ & Al rport & $43^{\circ}$ & $57^{\prime}$ & $81^{\circ} 20^{\prime}$ & 662.5 & $\begin{array}{c}(B \cdot . j \operatorname{lng} \\
t \text { ime })\end{array}$ & $4(2,8,14,20)$ \\
\hline
\end{tabular}

C. Number of Observations Usod for Calculating tho Dally Mean

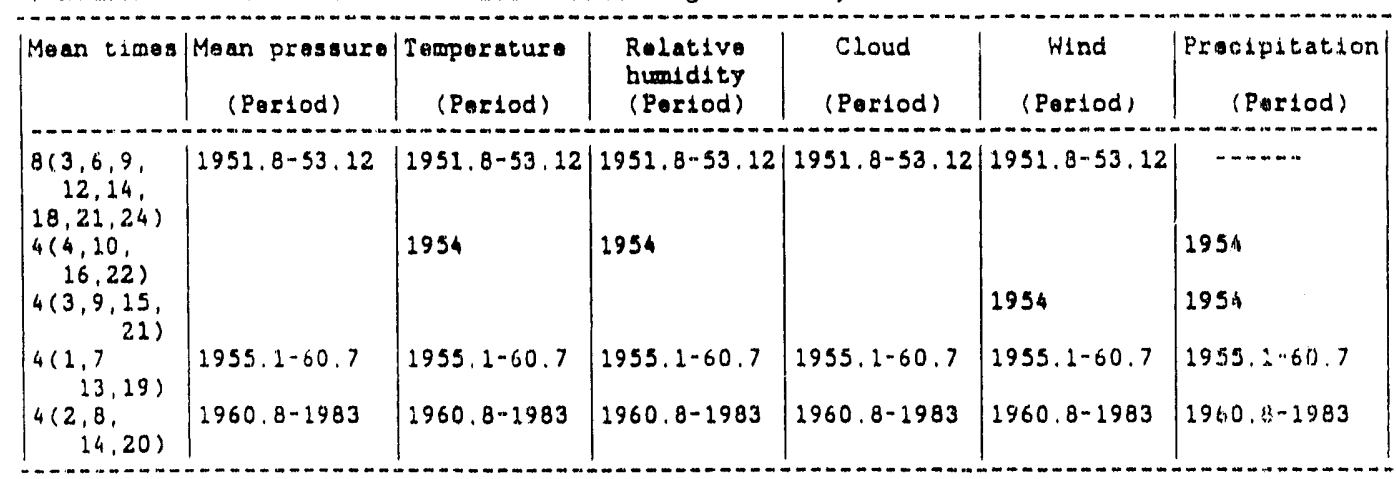

D. Remarks : 
No. 751463 Wh Lu Mu Q1

A. Mata Data Sources

$\begin{array}{lc}\text { 1. } 1907-1940 & (1)(3) \\ \text { 2. } 1941-1950 & (25) \\ \text { 3. } 1951-1980 & (26) \\ \text { 4. } 1981-1983 & (13) \\ \text { 5. } 1951.1-3 \text { (doosinant Winds) } & (12) \\ 1954.1-6 \text { (moan W:nd spoed) } & \text { (12) }\end{array}$

B. Location of Station, Time Standard and Times of Observation

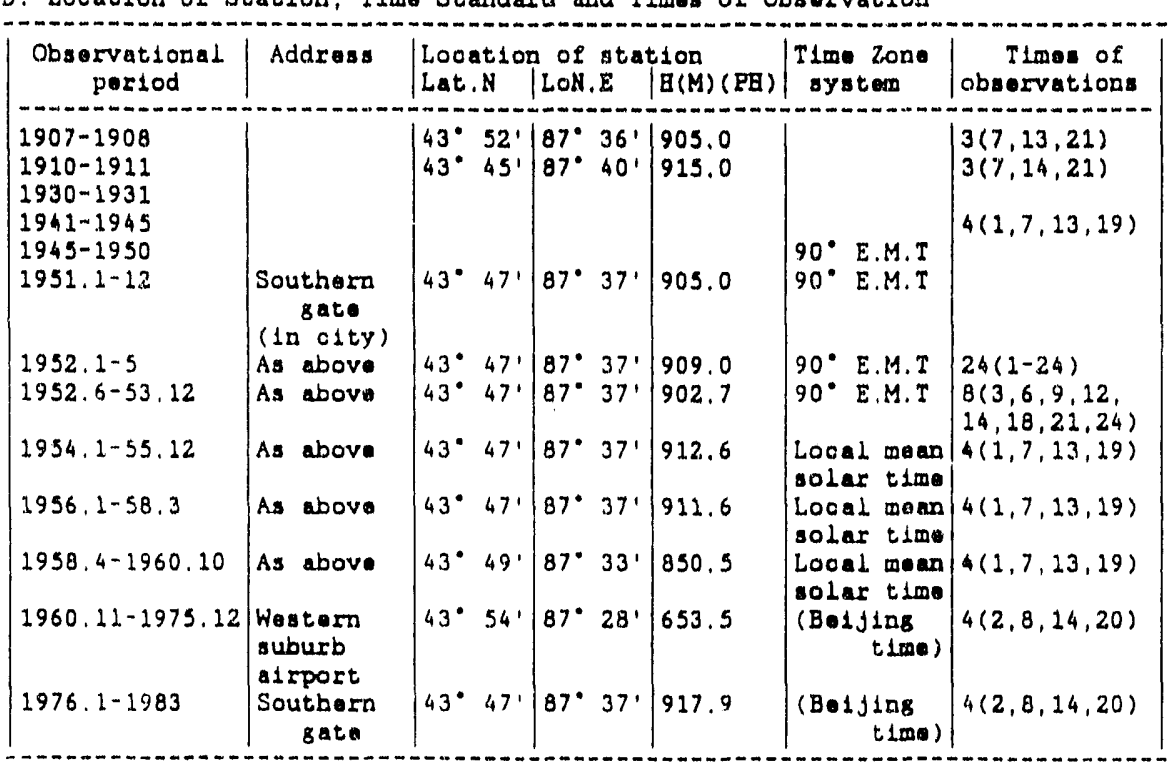

C. Number of observations uged for calculating the dolly moan

\begin{tabular}{|c|c|c|c|c|c|}
\hline Mean trmes & $\begin{array}{c}\text { Mean pressuro } \\
\text { (Perlod) }\end{array}$ & $\left|\begin{array}{c}\text { Temperatura } \\
\text { (Perlod) }\end{array}\right|$ & $\begin{array}{l}\text { Relative } \\
\text { humidity } \\
\text { (Period) }\end{array}$ & $\begin{array}{l}\text { Cloud } \\
\text { (Feriod) }\end{array}$ & $\begin{array}{l}\text { Wind } \\
\text { (Poriod) }\end{array}$ \\
\hline $\begin{array}{l}3(7,13,21) \\
3(7,14,21) \\
24(1-24) \\
4(1,7,13,19) \\
4(2,8,14,20)\end{array}$ & $\mid \begin{array}{l}1907-1908 \\
1910-1911.6 \\
1951-1953 \\
1954-1960.7 \\
1960.7-1983\end{array}$ & $\left|\begin{array}{l}1907-1908 \\
1910-1911.6 \\
1930-1931.5 \\
1951-1953 \\
1954-1960.7 \\
1960.7-1983\end{array}\right|$ & \begin{tabular}{|l}
$1951-1953$ \\
$1954-1960.7$ \\
1954 \\
$1960.7-1983$
\end{tabular} & $\begin{array}{l}1954-1960.7 \\
1960.7-1983\end{array}$ & $\begin{array}{l}1954-1.960 .7 \\
1960.8-1983\end{array}$ \\
\hline
\end{tabular}

D. Remasks:

1. Old namo: " 01 Bua "

2. Station has moved $31 x$ timea since 1950.

3. There was a Large change of position and elevation during 1960,11-1975.12. 
No. $8 \quad 52203$ Ha ML

A. Main Data Sourcas
1. $1951-1980$
2. $1981.1-1983$
1. $1951.1-3$ (dominant winds)
$1953,8-9$
1954,1-2,10-12 (Mean pressure)

B. Location of Station. Tlmo Standard and Times of Observation

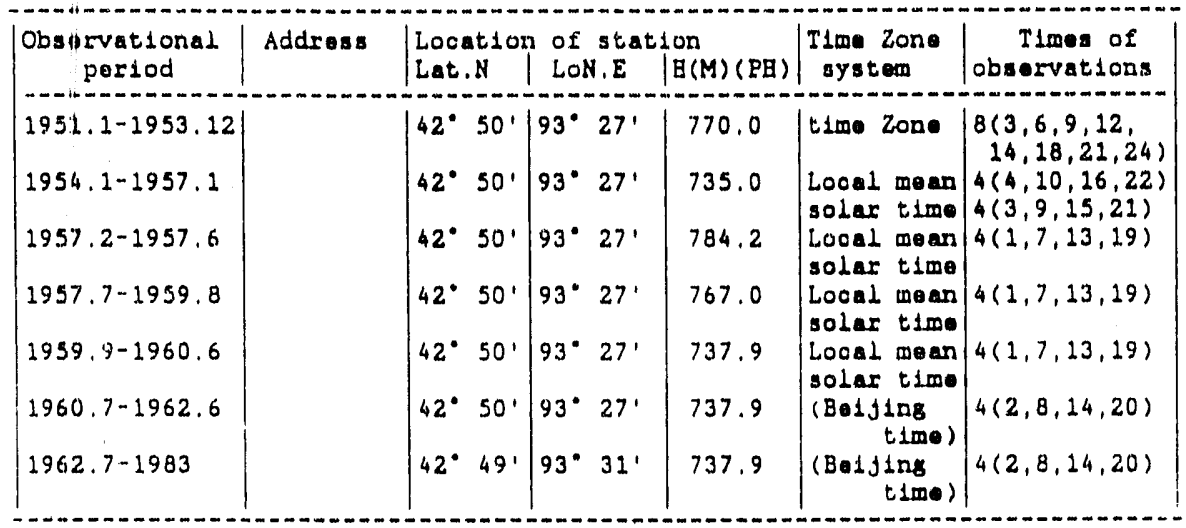

C. Number of Observations Used for Calculating tho Dadly Mean

\begin{tabular}{|c|c|c|c|c|}
\hline Moan times & $\begin{array}{c}\text { Mean presaure } \\
\text { (Period) }\end{array}$ & $\begin{array}{l}\text { Temperature } \\
\text { (Porjod) }\end{array}$ & $\begin{array}{c}\text { Rolativo humldity } \\
\text { (gorlod) }\end{array}$ & $\begin{array}{c}\text { Wind } \\
\text { (Poriod) }\end{array}$ \\
\hline $\begin{array}{l}8(3,6,9,12, \\
14,28,21,24) \\
4(4,10,16,22) \\
4(3,9,15,21)\end{array}$ & $1951-1953$ & $\begin{array}{l}1951-1953 \\
1954\end{array}$ & $\begin{array}{l}1951-1953 \\
1954\end{array}$ & $1951-1953$ \\
\hline $\begin{array}{l}4(1,7,13,19) \\
4(2,8,14,20)\end{array}$ & $\begin{array}{l}1955.1-1960.7 \\
1960.8-1983\end{array}$ & $\begin{array}{l}1955.1-1960.7 \\
1960.8-1983\end{array}$ & $\begin{array}{l}1955.1-1960.7 \\
1960.8-1983\end{array}$ & $\begin{array}{l}1954 \\
1955.1-1960.7 \\
1960.8-1983\end{array}$ \\
\hline
\end{tabular}

D. Remarks: 


\section{B-11}

No. 952533 J1L Quan

A. Main Data Sources

1. $1934,7-1950.12$

2. $1951-1969,12$

3. 1970 (wind, surshine, and preoipdtation)

4. $1971-1980$

5. 1934,7-1970 (Mean pressure, temperaturo,

humidity, and snow days) (31)

6. $1981-1983$

(28)

(29)

$(7)(9)(10)$

(30)

7. 1934-1936 (cloud amounts and dominant winds)

(13)

8. 1951-1962, 1971-1980 (Total amount of cloud)

(15)

1963-1970 ('Total amount of cloud)

$(156)$

B. Location of Station, TIme Standard and Tloos of Observation

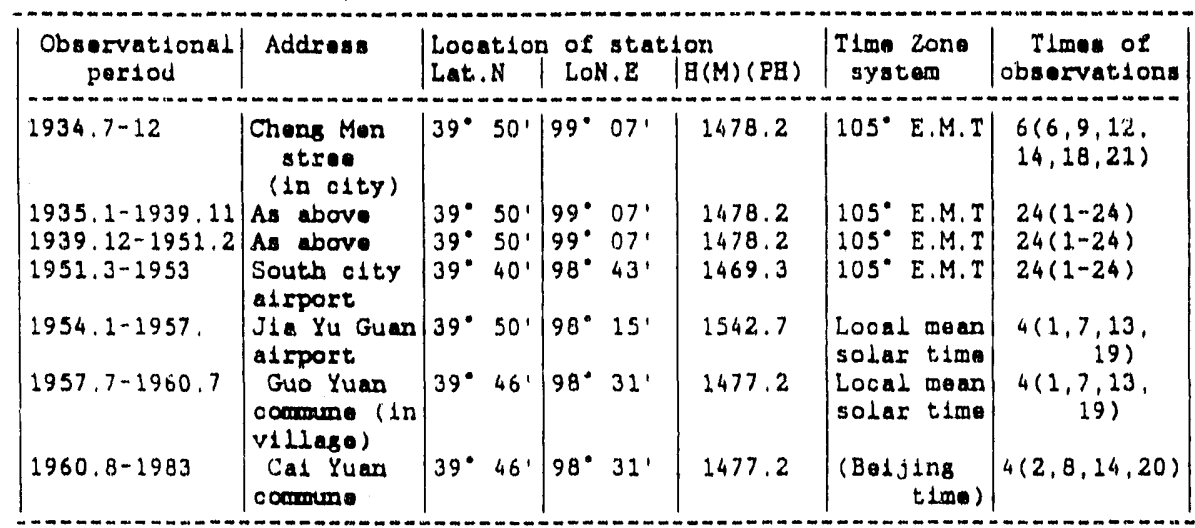

C. Number of Observationa Used for Caloulatiag the Dally Maan

\begin{tabular}{|c|c|c|c|c|}
\hline Mean times & $\begin{array}{c}\text { Moan prossura } \\
\text { (Porlod) }\end{array}$ & $\begin{array}{l}\text { Temperature } \\
\text { (Poriod) }\end{array}$ & $\left|\begin{array}{c}\text { Relat1ve humidity } \\
\text { (Porlod) }\end{array}\right|$ & $\begin{array}{l}\text { Wind } \\
\text { (Pariod) }\end{array}$ \\
\hline $\begin{array}{l}3(6,14,21) \\
24(1-24) \\
4(1,7,23,19) \\
4(2,8,14,20)\end{array}$ & & $\begin{array}{l}1934-1936.10 \\
1937-1953 \\
1954-1960.7 \\
1960.8-1983\end{array}$ & $\begin{array}{l}1934-1936,10 \\
1937-1953 \\
1954-1960.7 \\
1960.8-1983\end{array}$ & $\begin{array}{l}1957.7-1960.7 \\
1960.8-1983\end{array}$ \\
\hline
\end{tabular}

D. Remarks: 
A. Maln Data Sources

$\begin{array}{lc}\text { 1. } 1937-1950 & (37) \\ \text { 2. } 1951-1969 & (38) \\ \text { 3. } 1970 \text { iwind, prooipltation, and sunshias) } & (7)(9)(10)) \\ \text { 4. } 1951-1970 \text { (pressure, tomporature, } & (31) \\ \text { 5. } 1971-1980 \quad \text { humidity, and snow days) } & (39) \\ \text { 6. } 1981-1983 & (13) \\ \text { 7. } 1951-1962 \text { (total oloud amount) } & (12) \\ 1963-1970 \text { (total oloud amount) } & (136)\end{array}$

B. Location of Station. Tlme Standard and Timas of Observation

\begin{tabular}{|c|c|c|c|c|c|c|}
\hline $\begin{array}{c}\text { Observational } \\
\text { period }\end{array}$ & Addrese & $\left|\begin{array}{l}\text { Loontion } \\
\text { Lat.N }\end{array}\right|$ & $\begin{array}{l}\text { of stat } \\
\text { LON.E }\end{array}$ & $\begin{array}{l}\text { lon } \\
\mid \mathrm{g}(\mathrm{H})(\mathrm{PE})\end{array}$ & $\begin{array}{c}\text { T1me Zone } \\
\text { system }\end{array}$ & $\begin{array}{c}\text { Timea of } \\
\text { oberarvations }\end{array}$ \\
\hline $1937-1939$ & $\begin{array}{l}\text { Soutbeast } \\
\text { side of o1ty } \\
\text { (suburb) }\end{array}$ & $\left|38^{\circ} 56^{\prime}\right|$ & $100^{\circ} 37^{\prime}$ & & & $4(6,9,14,21)$ \\
\hline $\begin{array}{l}1940-1941 \\
1951-1953\end{array}$ & $\begin{array}{l}\text { As above } \\
\text { B18 Man Bao } \\
\text { South (coun- } \\
\text { trysido) }\end{array}$ & \begin{tabular}{ll|}
$38^{*}$ & $56^{\prime}$ \\
$38^{4}$ & $55^{\prime}$
\end{tabular} & $\begin{array}{l}100^{\circ} 37^{\prime} \\
100^{\circ} \\
35^{\prime}\end{array}$ & 1550.0 & $\begin{array}{l}\text { Looal tImo } \\
105^{\circ} \text { E.M.I }\end{array}$ & $\begin{array}{r}3(6,14,21) \\
8(3,6,9,22 \\
18,21,24)\end{array}$ \\
\hline $1954-1955.3$ & As. & $38^{\circ} 55^{\prime}$ & $100^{\circ} 35^{\prime}$ & 1550.0 & $\begin{array}{l}\text { Loond mean } \\
\text { solar timo }\end{array}$ & $4(1,7,13,19)$ \\
\hline $1955.4-1959.7$ & $\begin{array}{l}\text { "Lons Gong } \\
\text { Tomple" the } \\
\text { out of smald } \\
\text { south gate }\end{array}$ & $38^{\circ} 56^{\prime}$ & $100^{\circ} 35^{\prime}$ & 1479.5 & $\begin{array}{l}\text { Looal mean } \\
\text { solar time }\end{array}$ & $(1,7,13,19)$ \\
\hline $1959.8-1980.7$ & $\begin{array}{l}\text { Western gate } \\
\text { out (suburb) }\end{array}$ & $38^{\circ} 56^{\prime}$ & $100^{\circ} 35^{\prime}$ & 1468.5 & $\begin{array}{l}\text { Looul wean } \\
\text { solar t1mo }\end{array}$ & $(1,7,13,19)$ \\
\hline $1960,8-1962$ & As abovo & $38^{\circ} 56^{\circ}$ & $100^{\circ} 35^{\prime}$ & 1468.5 & 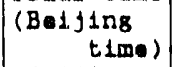 & $4(2,8,14,20)$ \\
\hline $1963-1983$ & As above & $38^{\circ} 56^{\prime}$ & $100^{\circ} 35^{\circ}$ & 1483.9 & $\begin{array}{c}(B \cdot 1, j \operatorname{lng} \\
t \perp \operatorname{mos})\end{array}$ & $4(2,8,14,20)$ \\
\hline
\end{tabular}

C. Number of Observations Used for Caloulating the Datly Moan

\begin{tabular}{|c|c|c|c|}
\hline Mean timas & $\begin{array}{l}\text { Temporaturo } \\
\text { (Porlod) }\end{array}$ & $\begin{array}{l}\text { Rolative humidity } \\
\text { (Poriod) }\end{array}$ & $\begin{array}{c}\text { Wind } \\
\text { (Por } \pm \text { od) }\end{array}$ \\
\hline $\begin{array}{l}3(6,14,21) \\
8(3,6,9,12,14 \\
18,21,24)\end{array}$ & $\begin{array}{l}1937.4-1941 \\
1951-1953 \\
1954-1960.7\end{array}$ & $\begin{array}{l}1937.4-1941 \\
1951-1953 \\
1954-1960.7\end{array}$ & $1951 \cdot 1953$ \\
\hline $4(2,8,14,20)$ & 1960.8-now & 1960.8 -now & 1960.8-now \\
\hline
\end{tabular}

D. Retnarks :

\footnotetext{
1. Date divided time: 22 local time during 1937-1941

$24 \quad 105^{\circ} \mathrm{E}$ mean twcoe during 1951-1953

19 Local mean solar time (L.M.S.T) during 1954-1960.7

20 Beijing time during 1960.8-1983
} 


\section{B-13}

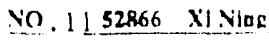

\begin{tabular}{|c|c|}
\hline$\therefore$ Maln Data Sources & Numocr of Dala \\
\hline 1. $1936-1949$ & $(1)(3)(5)(4$ \\
\hline$=1951.2-1953$ & $11: !$ \\
\hline 3. $1954.1-1970$ & 1321 \\
\hline$+1981-198 ?$ & $132:$ \\
\hline$\therefore 1961-1970$ (Total amouni ol ciouc & $(150)$ \\
\hline 1951-1953 (Snow dars & $(1561$ \\
\hline
\end{tabular}

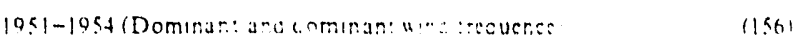

\begin{tabular}{|c|c|c|c|c|c|c|}
\hline \multirow{2}{*}{$\begin{array}{l}\text { Observalional } \\
\text { period }\end{array}$} & \multirow{2}{*}{ Addros } & \multicolumn{3}{|c|}{ Location of station } & \multirow{2}{*}{$\begin{array}{l}\text { Tume Zone } \\
\text { svstem }\end{array}$} & \multirow{2}{*}{$\begin{array}{c}\text { Times of } \\
\text { ouservation }\end{array}$} \\
\hline & & la: 1 & LONE & $H(M)(P H$ & & \\
\hline $193 n-1944$ & & $\therefore \cdot 1 \%$ & $101 \cdot 49$ & $2: 29$ & & \\
\hline $1951-19526$ & & $36 \cdot 35$ & $n \cdot s s$ & 22960 & & \\
\hline $1952.7-1953.1:$ & & $36^{*} ?$ & $101^{\circ} \leq 5$ & 22954 & E.MT & $\begin{array}{r}8(3,6,9,12 \\
14,18,21,24) \\
\end{array}$ \\
\hline $1954.1-8$ & Small bnoge of $x$ Ning & $36^{\circ} 35^{\prime}$ & $101 \cdot s 5^{\prime}$ & 2231.1 & Local time & $14(1,7,13,19)$ \\
\hline $19549-1960 ?$ & No $=54$ stres: & $36^{\circ} 35^{\prime}$ & $101^{\circ} 59$ & 2261:: & $1=: x_{1}^{\prime}, \ldots r$ & $\therefore:-1910 !$ \\
\hline 1961) 8-1973.1: & $y+\leq 4$ sirse & $36^{\circ}: 4$ & $101^{\circ} \leq 5$ & 2261: & 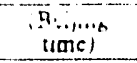 & $4(2,8,14,20)$ \\
\hline $1974.1-1983$ & so? s & $36^{\circ}:-$ & $101^{\circ} 46$ & 2261.2 & $\begin{array}{l}\text { (Beiling } \\
\text { umc) }\end{array}$ & $4(2,8,14,20)$ \\
\hline
\end{tabular}

\begin{tabular}{|c|c|c|c|c|}
\hline Mean umes & $\begin{array}{c}\text { Mean piessufe } \\
\text { (Period }\end{array}$ & $\begin{array}{c}\text { Temperature } \\
\text { iPcriod }\end{array}$ & $\begin{array}{l}\text { Relalive numidits } \\
\text { (Penod) }\end{array}$ & $\begin{array}{l}\text { Wind } \\
\text { (Penod) }\end{array}$ \\
\hline $3(6,14,21)$ & $1951-195311=$ & $1951-1953.12$ & $\begin{array}{l}1936,38,40 \quad 11-12 \\
41.12 .42 .9-43.3 . \\
9-12,44(3-12), 45.5\end{array}$ & \\
\hline $8(3,6,9,12$ & & & $1937.39-40.10 .41$ & \\
\hline 14.18 .21 .24 & & & $\begin{array}{c}(3-11), 42(1-8), 43 \\
(4-8), 45,6-5 ?\end{array}$ & \\
\hline $411,7,13.191$ & $19: 4-1960^{\circ}$ & $1954-1960^{-}$ & $1954-19607$ & $1957 i-19607$ \\
\hline $4(2,8,14,20)$ & $1960 k-1963$ & $1960 x-198 ?$ & $19608-198 ?$ & $19608-198 ?$ \\
\hline
\end{tabular}

… Kemarks columr. 


\section{B-14}

No. $12 \quad 52889$ Lan Zhou

A. Main Data Sources

$\begin{array}{ll}\text { 1. } 1932.6-1950 & (33)(34) \\ \text { 2. } 1951-1969 & (35) \\ \text { 3. } 1932-1970 & (31) \\ \text { 4. } 1970 \text { (wind, procipitation, and sunshine) } & (7)(9)(10) \\ \text { 5. } 1971-1980 & (36) \\ \text { 6. } 1981-1983 \text { (13) } & (15) \\ \text { 7. } 1933-1936 \text { (moan wind spocd) } & (193) \\ 1934-1936 \text { (dominant winds) } & (12) \\ \text { 8. } 1951-1962 \text { (cloud amount) } & (156) \\ 1963-1970 \text { (cloud amount) } & \end{array}$

B. Location of Station. TIme Standard and Tlmos of Obsorvation

\begin{tabular}{|c|c|c|c|c|c|c|c|}
\hline $\begin{array}{l}\text { Observational } \\
\text { period }\end{array}$ & Addros: & $\left|\begin{array}{l}\text { Location } \\
\text { Lat.N }\end{array}\right|$ & $\mid \begin{array}{l}\text { of stati } \\
\text { LoN.E }\end{array}$ & $\begin{array}{l}\text { lon } \\
\mid \mathrm{B}(\mathrm{M})(\mathrm{PB})\end{array}$ & Timo 2 & Zone & $\begin{array}{l}\text { Times of } \\
\text { observations }\end{array}$ \\
\hline 1932.6 & $\begin{array}{l}\text { In Garden of } \\
\text { XI Guan Gu }\end{array}$ & $\left|\begin{array}{ll}36^{\circ} & 03^{\prime}\end{array}\right|$ & $\left|204^{\circ} 48^{\circ}\right|$ & 1556.0 & $120^{\circ} \mathrm{E}$ & E.M.I & $4(6,10,11,18)$ \\
\hline 1932.7 & As above & $36^{\circ} 03^{\circ}$ & $104^{\circ} 48^{\prime}$ & 1556.0 & $120^{\circ} \mathrm{E}$ & E.M.I & $\begin{array}{r}6(5,8,11,14 \\
18,21)\end{array}$ \\
\hline $1932.8-1934.1$ & As above & $36^{\circ} 03^{\prime}$ & $204^{\circ} 48^{\prime}$ & 1556.0 & $120^{\circ} \mathrm{F}$ & E.M. $Y$ & $\begin{array}{r}9(5,8,11,14 \\
18,21)\end{array}$ \\
\hline $\begin{array}{l}1934,2-1934,12 \\
1935-1943\end{array}$ & $\begin{array}{l}\text { As above } \\
\text { out of East- } \\
\text { ern side Ba- } \\
\text { to }\end{array}$ & $\left|\begin{array}{ll}36^{\circ} & 03^{\prime} \\
36^{\circ} & 03^{\prime}\end{array}\right|$ & $\begin{array}{l}104^{\circ} 48^{\prime} \\
103^{\circ} 51^{\prime}\end{array}$ & $\begin{array}{r}1556.0 \\
4508.5\end{array}$ & $\begin{array}{l}120^{\circ} \\
120^{\circ}\end{array}$ & $\begin{array}{l}\text { E.M.T } \\
\text { E.M.T }\end{array}$ & $\begin{array}{l}24(5-22,23-4) \\
24(5-22,23-4)\end{array}$ \\
\hline $\begin{array}{l}1944 \\
1945-1950.10 \\
1950.11-1952\end{array}$ & $\begin{array}{l}\text { As above } \\
\text { As above } \\
\text { A1rport of } \\
\text { Eastery } \\
\text { suburb }\end{array}$ & $\begin{array}{ll}36^{\circ} & 03^{\prime} \\
36^{\circ} & 03^{\prime} \\
36^{\circ} & 03^{\prime}\end{array}$ & $\begin{array}{l}103^{\circ} 51^{\circ} \\
103^{\circ} 51^{\circ} \\
103^{\circ} 57^{\circ}\end{array}$ & $\begin{array}{l}1508.5 \\
1508.5 \\
1520.0\end{array}$ & $\begin{array}{l}120^{\circ} \\
105^{\circ} \\
105^{\circ}\end{array}$ & $\begin{array}{l}\text { E.M.I } \\
\text { E.M.I } \\
\text { E.M.T }\end{array}$ & $\begin{array}{l}24(1-24) \\
24(1-24) \\
24(1-24)\end{array}$ \\
\hline 1953 & $\begin{array}{l}\text { No. } 55 \text { Shens } \\
\text { Li road, out } \\
\text { of Eastern } \\
\text { side gate }\end{array}$ & $36^{\circ} 01^{\prime}$ & $103^{\circ} 59^{\prime}$ & 1.507 .8 & $105^{\circ} \mathrm{E}$ & E.M.T & $24(1-24)$ \\
\hline $1954-1956.6$ & As above & $36^{\circ} 01^{\prime}$ & $103^{\circ} 59^{\prime}$ & 1517.2 & $\begin{array}{l}\text { Local } \\
\text { solar }\end{array}$ & mean & $4(1,7,13,19)$ \\
\hline $1956.7-1960.7$ & $\begin{array}{l}\text { No.8 Swal1 } \\
\text { Gons Xins } \\
\text { Dun Eastern } \\
\text { suburb }\end{array}$ & $36^{\circ} 03^{\prime}$ & $103^{\circ} 53^{\prime}$ & 1517.2 & $\begin{array}{l}\text { Local } \\
\text { solar }\end{array}$ & $=$ & $4(1,7,13,19)$ \\
\hline $1960.8-1983$ & $\begin{array}{l}\text { No. 456, East } \\
\text { road, Dong } \\
\text { Gang (suburb) }\end{array}$ & $36^{\circ} 03^{\circ}$ & $103^{\circ} 53^{\circ}$ & 1517.2 & (B०1) & $\begin{array}{l}\operatorname{lng} 8 \\
t 1 m 0)\end{array}$ & $4(2,8,14,20)$ \\
\hline
\end{tabular}

$\therefore$ :lumber of Observations Used for Calculaniling the Dally Mean

\begin{tabular}{|c|c|c|c|c|}
\hline Mean tzmos & 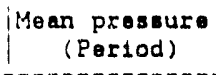 & $\begin{array}{c}\text { Temperature } \\
\text { (Pertod) }\end{array}$ & $\left|\begin{array}{c}\text { Relative humidity } \\
\text { (Perlod) }\end{array}\right|$ & $\begin{array}{l}\text { Nind } \\
\text { (Period) }\end{array}$ \\
\hline $\begin{array}{l}24(1-24) \\
4(1,7,13,19) \\
4(2,8,14,20)\end{array}$ & $\mid \begin{array}{l}1932.6-1947 \\
1948-1953 \\
1954-1960.7 \\
1960.8-1969\end{array}$ & $\begin{array}{l}1932.6-1934.1 \\
1934.2-1953 \\
1954-1960.7 \\
1960.8-1983\end{array}$ & $\begin{array}{l}1932.6-1934.1 \\
1934.2-1953 \\
1954-1960.7 \\
1960.8-1983\end{array}$ & $\begin{array}{l}1957.7-1960.7 \\
1960.8-1983\end{array}$ \\
\hline
\end{tabular}

D. Remarks :

L. Date divided t2me: $22120^{\circ} E$ moan time during 1932-1945 $24105^{\circ}$ E man timo during $1946-1953$

19 local mean solar t1me (L.M.S.T.) during 1954-1960.7

20 Beijing time during $1960.8-1983$

2 . In 24 times observations, data are from autographic records for the period 23 p.m.to 4 a.m. 
No. 1353463 8u Ho HaO To

A. Main Data Sources

$\begin{array}{ll}\text { 1. } 1920-1950 & (40) \\ \text { 2. } 1951-1980 & (41) \\ \text { 3. } 1981-1983 & (13)\end{array}$

H. Location of Station, TIme Standard and TImes of Obsorvation

\begin{tabular}{|c|c|c|c|c|c|c|}
\hline $\begin{array}{c}\text { Observational } \\
\text { period }\end{array}$ & Addrass & $\left|\begin{array}{l}\text { Locat 1 on } \\
\text { Lat.N }\end{array}\right|$ & $\left\{\begin{array}{l}\text { of stat } \\
\text { LON.E }\end{array}\right.$ & $\begin{array}{l}\text { lon } \\
\text { I }(M)(P B)\end{array}$ & $\begin{array}{l}\text { Tlmo Zono } \\
\text { system }\end{array}$ & $\begin{array}{c}\text { Times of } \\
\text { observations }\end{array}$ \\
\hline $1920-1947.3$ & $\begin{array}{l}\text { Gut Sut Sht } \\
\text { Da Tai Shen } \\
\text { Cat agricu- } \\
\text { lewre achool }\end{array}$ & $40^{\circ} 48^{\prime} \mid$ & $111^{\circ} 38^{\prime}$ & 1035.0 & $120^{\circ}$ E.M.T & $3(6,14,21)$ \\
\hline $\begin{array}{l}1947.4-1950 \\
1951-1953\end{array}$ & $\begin{array}{l}\text { As above } \\
\text { New oity of } \\
\text { Gud Sul East } \\
\text { gat out ai- }\end{array}$ & $\begin{array}{ll}40^{\circ} & 48^{\prime} \\
40^{\circ} & 49^{\prime}\end{array}$ & $111^{\circ} 38^{\prime}$ & $\begin{array}{l}1035.0 \\
1062.2\end{array}$ & $\begin{array}{l}105^{\circ} \text { E.M.T } \\
105^{\circ} \text { E.M.T }\end{array}$ & $\begin{array}{l}3(6,14,21) \\
8(3,6,9,12, \\
\quad 18,21,24)\end{array}$ \\
\hline $1954-1960.7$ & Al above & $40^{\circ} 49^{\prime}$ & $111^{\circ} 41^{\prime}$ & 1062.2 & Local moan & $4(1,7,13,19)$ \\
\hline $1960.8-1983$ & As above & $40^{\circ} 49^{\prime}$ & $111^{\circ} 41^{\prime}$ & 1063.0 & $\left(\begin{array}{c}\text { Boijung } \\
\text { time })\end{array}\right.$ & $4(2,8,14,20)$ \\
\hline
\end{tabular}

C. Number of Observntions Used for Calculating the Dally Mean

\begin{tabular}{|c|c|c|c|}
\hline Moan times & $\begin{array}{c}\text { Mean prossure } \\
\text { (Poriod) }\end{array}$ & $\begin{array}{c}\text { Temperature } \\
\text { (Pariod) }\end{array}$ & $\begin{array}{l}\text { Relative humidity } \\
\text { (Porlod) }\end{array}$ \\
\hline $\begin{array}{l}4(1,7,13,19) \\
4(2,8,14,20)\end{array}$ & $\begin{array}{l}1947-1950 \\
1951-1953 \\
1954-1960.7 \\
1960.8-1983\end{array}$ & $\begin{array}{l}1930-1937 \\
1939-1943 \\
1946-1950 \\
1954-1960.7 \\
1960.8-1983\end{array}$ & $\begin{array}{l}1934-1936 \\
1947-1950 \\
1951-1953 \\
1954-1960.7 \\
1960.8-1983\end{array}$ \\
\hline
\end{tabular}

D. Remarks :

1. Date divided time: $211^{\circ} \mathrm{E}$ meridian time before 1951 year $241^{\circ} \mathrm{O}$ meridian time during 1951-1953

19 local solar time (L.M.S.T.) during 1954-1980.7

20 Beijing time during 1960.8-1983

2. Minimum temperature for 1955.5, and sunghine hours and o.loud amounts for 1951-1980 were estimated.

3. Old namo: Gui Sul 
No. $14 \quad 53614$ Y1n Chuan

A. Main Data Sources

$\begin{array}{ll}\text { 1. } 1935-1938 & (1)(3) \\ \text { 2. } 1951-1960 & (42) \\ \text { 3. } 1951-1980 & (43) \\ \text { 4. } 1981-1983 & (13) \\ \text { 5. } 1951-1953 \text { (wean wind speed) } & (12)\end{array}$

B. Location of Station, Tlme Standard and Tlma of Observation

\begin{tabular}{|c|c|c|c|c|c|c|}
\hline $\begin{array}{c}\text { Obsorvational } \\
\text { portod }\end{array}$ & Addross & $\begin{array}{l}\text { Locat Ion } \\
\text { Lat. N }\end{array}$ & $\begin{array}{l}\text { of stati } \\
\text { LON.E }\end{array}$ & $\mid \mathrm{B}(\mathrm{M})(\mathrm{PB})$ & $\begin{array}{l}\text { Tlon zone } \\
\text { systam }\end{array}$ & $\begin{array}{c}\text { Times of } \\
\text { observatilons }\end{array}$ \\
\hline $\begin{array}{l}1935-1938 \\
1951.1-12\end{array}$ & $\begin{array}{l}\text { Weutern flow- } \\
\text { or gardion of } \\
\text { num oity }\end{array}$ & $\left|\begin{array}{ll}38^{\circ} & 28^{\prime} \\
38^{\circ} & 25^{\prime}\end{array}\right|$ & $\begin{array}{l}106^{\circ} 13^{\prime} \\
107^{\circ} \\
05^{\prime}\end{array}$ & $\begin{array}{l}1065.0 \\
1115.0\end{array}$ & $\begin{array}{l}120^{\circ} \text { E.M.T } \\
105^{\circ} \text { E.M.T }\end{array}$ & $\begin{array}{l}3(6,14,21) \\
3(6,14,21)\end{array}$ \\
\hline $1952.1 \% 5$ & As above & $38^{\circ} 25^{\prime}$ & $107^{\circ} 20^{\prime}$ & 1115.0 & $105^{\circ}$ E.M.I & $\begin{array}{c}8(3,6,9,12,14 \\
18,21,24)\end{array}$ \\
\hline $1952.6-11$ & As above & $38^{\circ} 25^{\prime}$ & $107^{\circ} 16^{\prime}$ & 1115.0 & $105^{\circ}$ E.M.T & $\begin{array}{c}8(3,6,9,12,14 \\
18,21,24)\end{array}$ \\
\hline 1952.12 & As above & $38^{\circ} 25^{\prime}$ & $107^{\circ} 16^{\prime}$ & 1120.0 & $105^{\circ}$ E.M.T & $\begin{array}{c}8(3,6,9,12,14 \\
18,21,24)\end{array}$ \\
\hline $1953.1-5$ & As above & $38^{\circ} 25^{\prime}$ & $107^{\circ} 16^{\prime}$ & 1115.0 & $105^{\circ}$ E.M.I & $\begin{array}{c}8(3,6,9,12,14 \\
18,21,2,4)\end{array}$ \\
\hline $1963.6-12$ & As above & $38^{\circ} 25^{\prime}$ & $107^{\circ} 16^{\prime}$ & 1101.3 & $105^{\circ}$ E.M.T & $\begin{array}{c}8(3,6,9,12,14 \\
18,21,24)\end{array}$ \\
\hline 1954.1 & As above & $38^{\circ} 25^{\prime}$ & $107^{\circ} 16^{\prime}$ & 1101.3 & Local mean & $4(1,7,13,19)$ \\
\hline $1954.2-6$ & $\begin{array}{l}\text { Now city } \\
\text { "Zhen Xiang } \\
\text { village" }\end{array}$ & $38^{\circ} 25^{\prime}$ & $106^{\circ} 16^{\prime}$ & 1115.0 & $\begin{array}{l}\text { Losal mean } \\
\text { solar time }\end{array}$ & $4(1,7,13,19)$ \\
\hline $1954.7-1956.4$ & As above & $38^{\circ} 25^{\prime}$ & $106^{\circ} 16^{\prime}$ & 1111.5 & $\begin{array}{l}\text { Local mean } \\
\text { solar time }\end{array}$ & $4(1,7,13,19)$ \\
\hline $1956.5-1960.7$ & As aboven & $38^{\circ} 31^{\prime}$ & $106^{\circ} 16^{\prime}$ & 11111.5 & $\begin{array}{l}\text { Looul mean } \\
\text { solar time }\end{array}$ & $4(1,7,13,19)$ \\
\hline $1960.8-1971.1$ & As above & $38^{\circ} 31^{\prime}$ & $106^{\circ} 16^{\prime}$ & 1111.5 & $\begin{array}{c}\text { (B.1jing } \\
\text { eimo) }\end{array}$ & $4(2,8,14,20)$ \\
\hline $1971.2-1983$ & As above & $38^{\circ} 29^{\prime}$ & $106^{\circ} 13^{\prime}$ & $\left|\begin{array}{l}1111.5 \\
(1112.2)\end{array}\right|$ & $\left(\begin{array}{c}\text { (B) } 1 \text { ) } 1 \mathrm{ing} \\
\text { time }\end{array}\right.$ & $4(2,8,14,20)$ \\
\hline
\end{tabular}

C. Number of Observations Used for Calculating the Dally Mean

\begin{tabular}{|c|c|c|c|c|}
\hline Mean times & $\begin{array}{c}\text { Moon pressure } \\
\text { (Period) }\end{array}$ & $\begin{array}{c}\text { Tamporature } \\
\text { (Poriod) }\end{array}$ & $\begin{array}{l}\text { Relatilue burnidity } \\
\text { (Porl }\end{array}$ & $\begin{array}{l}\text { Wind } \\
\text { (Poriod) }\end{array}$ \\
\hline $\begin{array}{l}3(6,14,21) \\
8(3,6,9,12,14, \\
18,21,24) \\
4(1,7,23,19) \\
4(2,3,14,20)\end{array}$ & $\begin{array}{l}1952.1-1953 \\
1954.1-1960.7 \\
1960.8-1983\end{array}$ & $\begin{array}{l}1935-1938 \\
1951,1-12 \\
1937-1953 \\
1952-1953 \\
1954.1-1960.7 \\
1960.8-1983\end{array}$ & $\begin{array}{l}1951.1-12 \\
1937-1953 \\
1952-1953 \\
1954.1-1960.7 \\
1960.8-1983\end{array}$ & $\begin{array}{l}1954.1-1960.7 \\
1960.8-1983\end{array}$ \\
\hline
\end{tabular}

D. Remarks:

1. Old name: "MIng X1a". 
A. Main Data Souroas
1. Before 1950
2. $1951-1960$
3. $1961-1970$
4. $1971-1980$
5. $1981-1983$
6. $1961-1963$ $1964-1970$
7. 1971-1980 (dominant wirds)
1971-1980 (snow days)

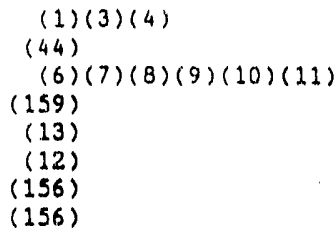

B. Location of Station, Time Standard and Times of Observation

\begin{tabular}{|c|c|c|c|c|c|c|c|}
\hline $\begin{array}{l}\text { Observational } \\
\text { poriod }\end{array}$ & Address & $\mid \begin{array}{l}\text { Location } \\
\text { Lat.N } \mid\end{array}$ & $\left|\begin{array}{l}\text { of stat1 } \\
\text { LON.E }\end{array}\right|$ & $\begin{array}{l}100 \\
|\mathrm{~B}(\mathrm{M})(\mathrm{PB})|\end{array}$ & $\mid \begin{aligned} \text { Time } \\
\text { syate }\end{aligned}$ & zone & $\begin{array}{c}\text { Times of } \\
\text { observationa }\end{array}$ \\
\hline $\begin{array}{l}1933-1.50 \\
1951.1-2\end{array}$ & $\begin{array}{l}\text { Lu Second } \\
\text { pedagog } 1 \text { cal } \\
\text { school-up } \\
\text { a.lley }\end{array}$ & $\left|\begin{array}{ll}38^{\circ} & 17^{\prime} \\
38^{\circ} & 15^{\prime}\end{array}\right|$ & $\left|\begin{array}{ll}109^{\circ} & 45^{\prime} \\
109^{\circ} & 25^{\prime}\end{array}\right|$ & $\mid \begin{array}{l}1120.7 \\
1094.2\end{array}$ & $\begin{array}{l}120^{\circ} \\
120^{\circ}\end{array}$ & $\begin{array}{l}\text { E.M.T. } \\
\text { E.M.I }\end{array}$ & $\begin{array}{l}\text { 21) } \\
\text { 21) }\end{array}$ \\
\hline $\begin{array}{l}1951.3-11 \\
1951.12-1952.10\end{array}$ & $\begin{array}{l}\text { Aa above } \\
\text { NO. 4-Up al1- } \\
\text { oy of Shong } \\
\text { L (1D c1ty) }\end{array}$ & $\begin{array}{ll}38^{\circ} & 15^{\prime} \\
38^{\circ} & 15^{\prime}\end{array}$ & $\begin{array}{l}109^{\circ} 25^{\prime} \\
109^{\circ} \\
25^{\prime}\end{array}$ & $\begin{array}{l}1094.2 \\
1094.2\end{array}$ & $\begin{array}{l}105^{\circ} E \\
105^{\circ} E\end{array}$ & $\begin{array}{l}E, M, T \\
E, M, T\end{array}$ & $\begin{array}{l}3(6,14,21) \\
8(3,6,9,12, \\
14,18,21,24)\end{array}$ \\
\hline $1952.11-1953.12$ & $\begin{array}{ll}\text { No. 2. } & \text { Middlo } \\
\text { a L1 oy } & \text { of } \\
\text { Shong L } & \end{array}$ & $38^{\circ} \quad 15^{\prime}$ & $109^{\circ} 25^{\prime}$ & 1094.2 & $105^{\circ} \mathrm{E}$ & E.M.T & $\begin{array}{l}8(3,6,9,12, \\
14,18,21,24)\end{array}$ \\
\hline $\begin{array}{l}1954.1-3 \\
1954.4-1956.7\end{array}$ & $\begin{array}{c}\text { Aa abov } \\
\text { We1-Za alley } \\
\text { mouth }\end{array}$ & $\begin{array}{ll}38^{\circ} & 15^{\prime} \\
38^{\circ} & 15^{\prime}\end{array}$ & $\begin{array}{l}109^{\circ} 25^{\prime} \\
109^{\circ} \\
25^{\prime}\end{array}$ & & $\begin{array}{l}\text { Lacal } \\
\text { Local }\end{array}$ & $\left|\begin{array}{l}t 1 m 0 \\
t 1 m_{0}\end{array}\right|$ & $\begin{array}{l}4(1,7,13,19) \\
4(1,7,13,19)\end{array}$ \\
\hline $\begin{array}{l}1956.8-1960.7 \\
1960.8-1962.12\end{array}$ & $\begin{array}{l}\text { As abovo } \\
\text { South gute } \\
\text { out airort } \\
\text { ( suburb) }\end{array}$ & $\left|\begin{array}{ll}38^{\circ} & 15^{\prime} \\
38^{\circ} & 17^{\prime}\end{array}\right|$ & $\begin{array}{l}109^{\circ} 25^{\prime} \\
109^{\circ} \\
25^{\prime}\end{array}$ & $\begin{array}{l}1054.0 \\
1057.5\end{array}$ & $\begin{array}{l}\text { Loond } \\
\text { (B.1f1 }\end{array}$ & $\begin{array}{l}t 1 m 0 \\
\operatorname{lng} \\
\lim \theta\end{array}$ & $\begin{array}{l}4(1,7,13,19) \\
4(2,8,14,20)\end{array}$ \\
\hline $1963.2-1983$ & & $38^{\circ} 14^{\prime}$ & $109^{\circ} 42^{\prime}$ & 1057.5 & (B) 1 & $\begin{array}{l}\operatorname{lng} \\
t \log (\infty)\end{array} \mid$ & $4(2,8,14,20)$ \\
\hline
\end{tabular}

C. Number of Observations Used for Calculating the Dally Mean

\begin{tabular}{|c|c|c|c|}
\hline Mean times & $\begin{array}{c}\text { Mean pressura } \\
\text { (Poriod) }\end{array}$ & $\begin{array}{c}\text { Temporature } \\
\text { (Poriod) }\end{array}$ & $\begin{array}{l}\text { Rolative humidity } \\
\text { (Portod) }\end{array}$ \\
\hline $\begin{array}{l}3(6,14,21) \\
8(3,6,9,12,14, \\
28,21,24) \\
4(1,7,13,19)\end{array}$ & $1951-1953$ & $1951-1953$ & $\begin{array}{l}1936.11-1948 \\
1951-1953 \\
1952-1953 \\
\\
1954-1960.7\end{array}$ \\
\hline $4(2,8,14,20)$ & $1960.8-1903$ & $1960.8-1983$ & $1960.8-1983$ \\
\hline
\end{tabular}

D. Remarks : 
B-18

No. $16 \quad 53772$ Ta1 Yuan

A. Main Data Sources

$\begin{array}{lr}\text { 1. } 1916-1950 & (45) \\ \text { 2. } 1951-1990 & (46) \\ \text { 3. } 1971-1980 & (159) \\ \text { 4. } 1981-1983 & (13) \\ \text { 5. } 1971-1980 & (156)\end{array}$

B. Location of Station, Tlme Standard and IImes of Observation

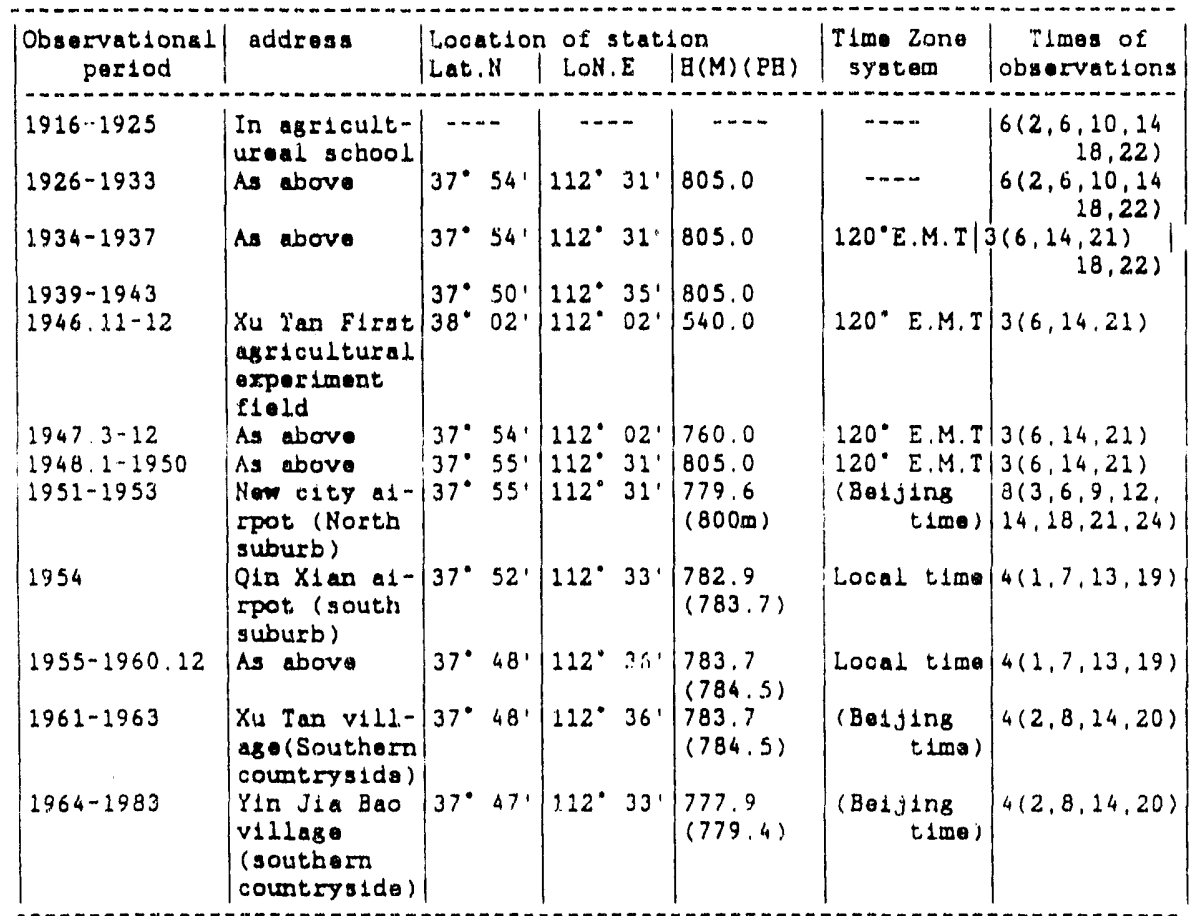

c. Number of Observations Used for Calculating the Dally Mean

\begin{tabular}{|c|c|c|c|}
\hline Mean times & $\begin{array}{c}\text { Mean pressuro } \\
\text { (Period) }\end{array}$ & $\begin{array}{l}\text { Temperaturo } \\
\text { (Period) }\end{array}$ & $\begin{array}{c}\text { Relative humidd ty } \\
\text { (Porlod) }\end{array}$ \\
\hline $3(6,14,2.1)$ & $\begin{array}{l}1934-1937.9 \\
1951-1953\end{array}$ & $\begin{array}{l}1934-1937.9 \\
1950-1953\end{array}$ & $\begin{array}{l}1934-1937.9 \\
1950-1953\end{array}$ \\
\hline $\begin{array}{r}6(2,6,20,14,18 \\
22)\end{array}$ & $1916-1933$ & $\begin{array}{l}1916-1933 \\
1939-1943 \\
1946.11-12\end{array}$ & 291641933 \\
\hline $\begin{array}{l}4(1,7,: 3,19) \\
4(2,8,14,20)\end{array}$ & $\begin{array}{l}2954-1960.7 \\
1960.8-1983\end{array}$ & $\begin{array}{l}1947.3-1948 \\
1954-1960.7 \\
1960.8-1983\end{array}$ & $\begin{array}{l}1947.3-1948 \\
1954-1960.7 \\
1960.8-1983\end{array}$ \\
\hline
\end{tabular}

D. Remarks :

1. Mean pressure wes presaure of the ice point dureng the 1?16-1935.

2. Date divided time: 24 Beljing time during 1951-1953

19 Local time during $1954-1960.7$

20 Beijlng time duriag $1960.8-1983$

2. Old name: "Yans ou 
No. 1754094 Mu Dan Jlang

A. Main Data Sources

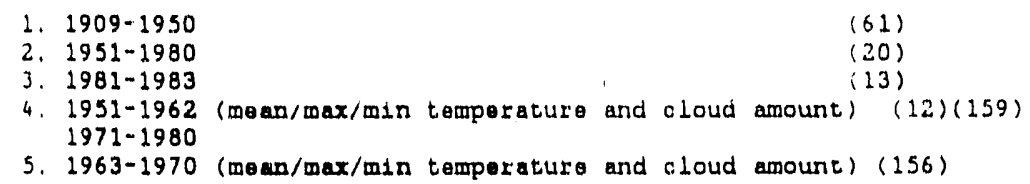

B. Location of Station, TImo Standard and Times of Observation

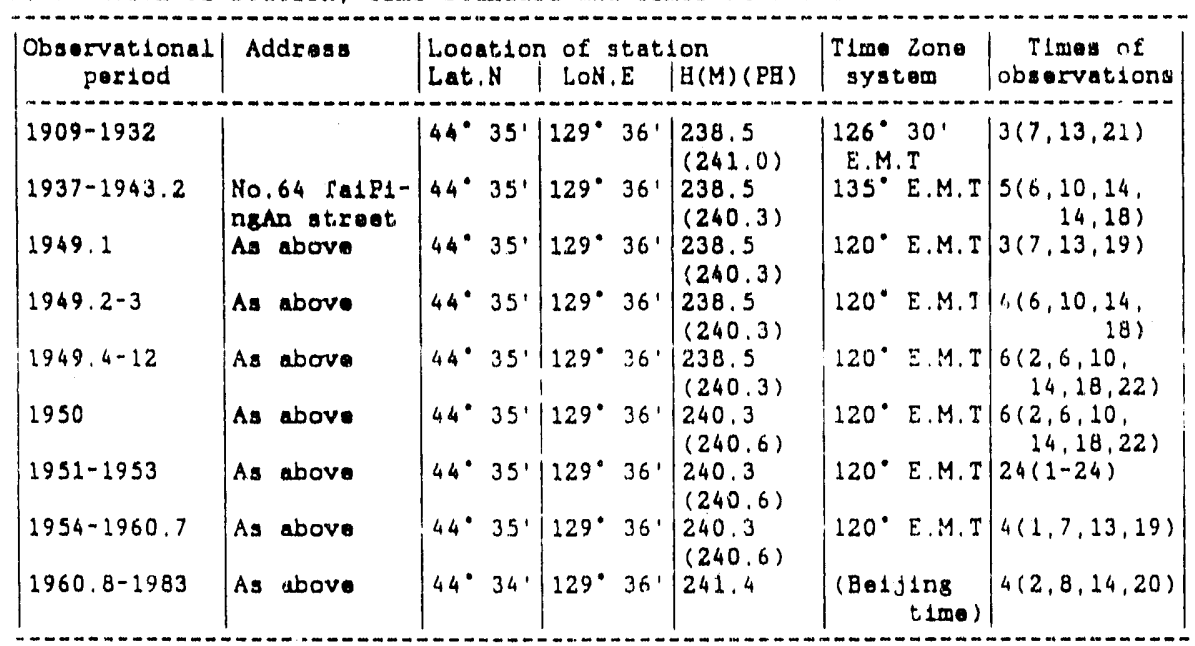

C. Number of Observations Used for Calculating the Dally Moun

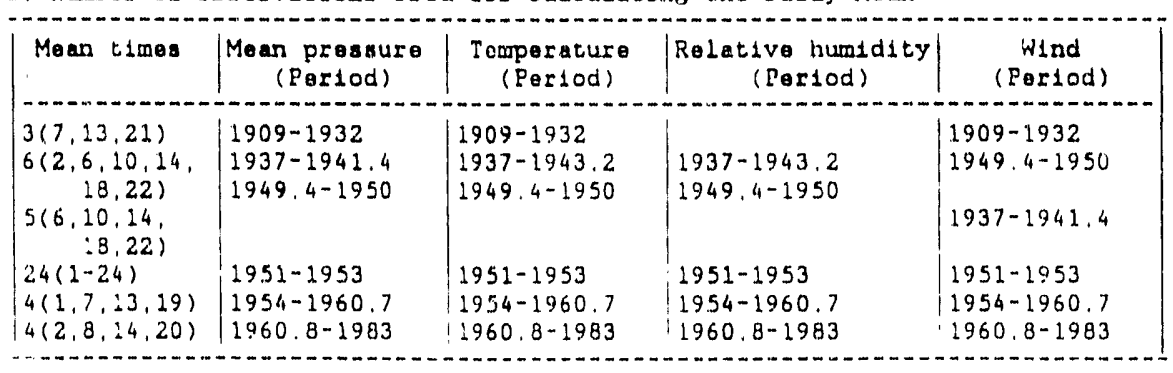

D. Remarks : 


\section{B-20}

No. 1854161 Chang Chun

A. Main Data Sourcos
1. $1909-1950$
2. $1951-1980$
(47)
3. $1981-1983$
$(48)$
(13)

B. Looation of Station, Tlme Standard and Iimes of Observation

\begin{tabular}{|c|c|c|c|c|c|c|}
\hline $\begin{array}{c}\text { Observational } \\
\text { period }\end{array}$ & Addrass & $\left|\begin{array}{l}\text { Loontion } \\
\text { Lat.N }\end{array}\right|$ & $\left\{\begin{array}{l}\text { of stat } \\
\text { LoN.E }\end{array}\right.$ & $\begin{array}{l}\text { Ion } \\
\mid \mathrm{B}(\mathrm{M})(\mathrm{PB})\end{array}$ & $\begin{array}{c}\text { Time Zone } \\
\text { system }\end{array}$ & $\begin{array}{c}\text { riges of } \\
\text { observations }\end{array}$ \\
\hline $1909-1936$ & $\begin{array}{l}\text { East and of } \\
\text { fros broad } \\
\text { road, Nanling }\end{array}$ & $43^{\circ} 52^{\prime} \mid$ & $125^{\circ} 20^{\prime}$ & 215.7 & $120^{\circ}$ E.M.T & $\begin{array}{r}6(2,6,10,14 \\
18,22)\end{array}$ \\
\hline $\begin{array}{l}1949-1950 \\
1937-1942\end{array}$ & $\begin{array}{l}\text { As bove } \\
\text { As above }\end{array}$ & $43^{\circ} 52^{\prime}$ & $225^{\circ} 20^{\prime}$ & 215.7 & $135^{\circ}$ E.M.T & $\begin{array}{r}6(2,6,10,14 \\
18,22)\end{array}$ \\
\hline $1947-1950$ & As above & $43^{\circ} 52^{\prime}$ & $125^{\circ} 20^{\prime}$ & 215.7 & $\begin{array}{l}127^{\circ} 30^{\prime} \\
\text { E.M.T }\end{array}$ & $\begin{array}{l}8(3,6,9,12 \\
14,18,21,24)\end{array}$ \\
\hline $\begin{array}{l}1951-1953 \\
1954-1960.7\end{array}$ & & $\begin{array}{l}43^{\circ} .53^{\prime} \\
43^{\circ} 53^{\prime}\end{array}$ & $\begin{array}{l}125^{\circ} 13^{\prime} \\
125^{\circ} 13^{\prime}\end{array}$ & $\begin{array}{l}236.8 \\
236.8\end{array}$ & $\begin{array}{l}120^{\circ} \text { E.M. T } \\
\text { Lood moan } \\
\text { solar t tme }\end{array}$ & $\begin{array}{l}24(1-24) \\
4(1,7,23,19)\end{array}$ \\
\hline $1960.8-1983$ & & $43^{\circ} 53^{\prime}$ & $125^{\circ} 13^{\prime}$ & 236.8 & $\begin{array}{c}(B \operatorname{lj} \operatorname{lng} \\
\operatorname{tim\theta })\end{array}$ & $4(2,8,14,20)$ \\
\hline
\end{tabular}

C. Number of Observations Usod for Calculatiog the Dally Mean

\begin{tabular}{|c|l|l|l|}
\hline Mean times & $\begin{array}{l}\text { Mean prossure } \\
\text { (Par1od) }\end{array}$ & \multicolumn{1}{|c|}{$\begin{array}{c}\text { Temperature } \\
\text { (Por1od) }\end{array}$} & $\begin{array}{c}\text { Relative humidity } \\
\text { (Por1od) }\end{array}$ \\
\hdashline $3(6,14,21)$ & $1929.5-1936$ & $1929.5-1936$ & $1929.5-1936$ \\
$6(2,6,10,14$, & $1909-1929.4$ & $1909-1929.4$ & $1909-1929.4$ \\
$18,22)$ & $1937-1941.4$ & $1937-1942.4$ & $1937-1942.4$ \\
& $1949-1950$ & $1949-1950$ & $1949 \cdots 1950$ \\
$8(3,6,9,12$, & & $1947-1948$ & $1,947-1948$ \\
$14,18,21,24)$ & & & \\
$24(1-24)$ & $1951-1953$ & $1951-1953$ & $1951-1953$ \\
$4(1,7,13,19)$ & $1954-1960.7$ & $1954-1960.7$ & $1954-1960.7$ \\
$4(2,8,14,20)$ & $1960.8-1983$ & $1960.8-1983$ & $1960.8-1983$ \\
\hline
\end{tabular}

D. Remark.3. 


\section{B-21}

No. $19 \quad 54342$ Shon Yarig

A. Main Data Sourcos

$\begin{array}{ll}\text { 1. } 1905-1950 & (49) \\ \text { 2. } 1951-1960 & (50) \\ \text { 3. } 1961-1970 & (51) \\ \text { 4. } 1971-1980 & (51) \\ \text { 5. } 1981-1983 & (13)\end{array}$

B. Looation of Station, TIme Standard and TImes of Observation

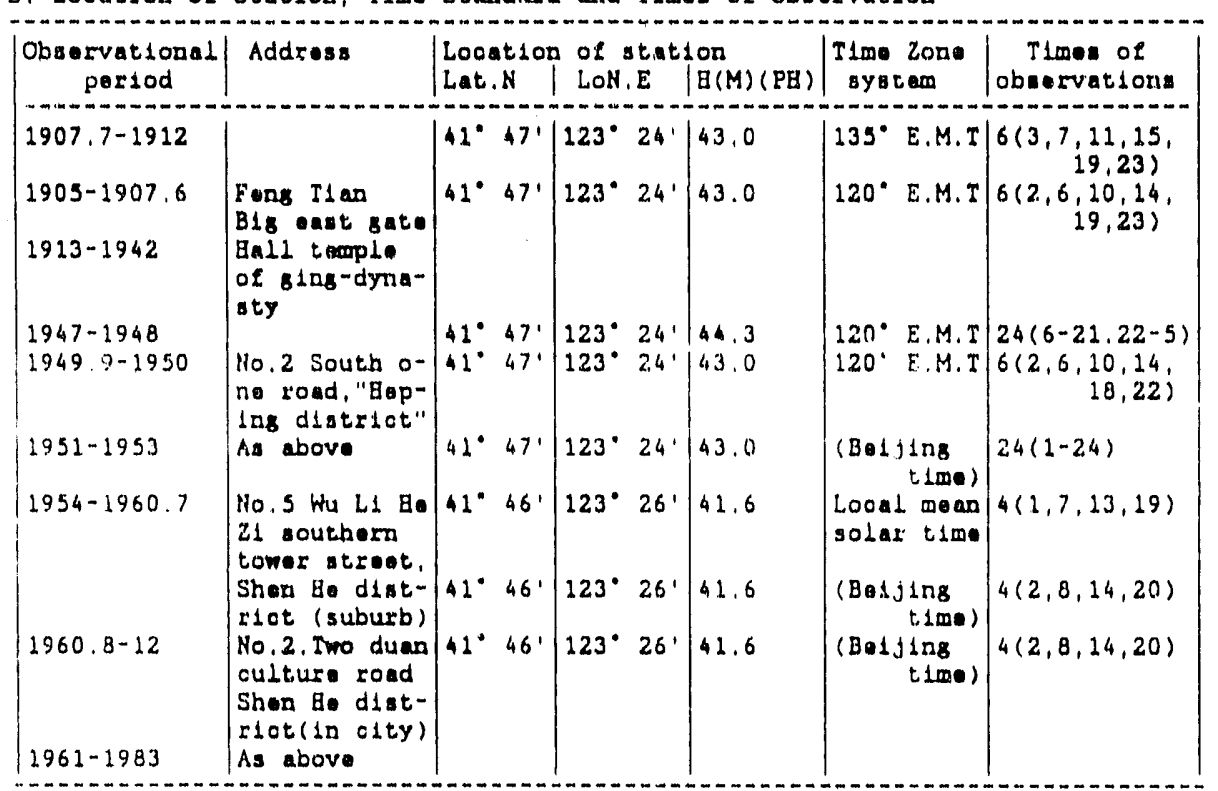

C. Number of Observations Used for Caloulating the Dally Mean

\begin{tabular}{|c|c|c|c|c|}
\hline Mean ticoses & $\begin{array}{c}\text { Moan prosaure } \\
\text { (Poriod) }\end{array}$ & $\begin{array}{c}\text { Teopparature } \\
\text { (Pariod) }\end{array}$ & $\begin{array}{l}\text { Rolative humidity } \\
\text { (Poriod) }\end{array}$ & $\begin{array}{l}\text { Wind } \\
\text { (Porlod) }\end{array}$ \\
\hline $3(6,14,22)$ & 1950 & $\begin{array}{l}1929.5-1936.7 \\
1905-1907.6\end{array}$ & 1950 & \\
\hline $\begin{array}{r}6(2,6,20,14 \\
: 8,22)\end{array}$ & $\mid \begin{array}{l}1905-1907.6 \\
1913-1942,1949\end{array}$ & $\begin{array}{l}1913-1929.4 \\
1936.8-1942 \\
1949-1950\end{array}$ & $\begin{array}{l}1905-1907.6 \\
1913-1942,1949\end{array}$ & \\
\hline $\begin{array}{c}6(3,7,11,15) \\
\vdots 9,23) \\
24(1-24) \\
4(1,7,13,19) \\
4(2,8,14,20)\end{array}$ & $\begin{array}{l}1907.7-1912 \\
1947-1948 \\
1951-1933 \\
1954-1960.7 \\
1960.8-1983\end{array}$ & $\begin{array}{l}1907-1912 \\
1967-1948 \\
1951-1953 \\
1954-1960.7 \\
1960.8-1983\end{array}$ & $\begin{array}{l}1907.7-1912 \\
1947-1948 \\
1951-1953 \\
1954-1960.7 \\
1960.8-1983\end{array}$ & $\begin{array}{l}1951-1953 \\
1954-1960.7 \\
1960.8-1983\end{array}$ \\
\hline
\end{tabular}

\section{Remarks:}

There were more small wind speed and higher temperature during the $1951-1953$ yoars, because this atation was ill city, The records has a better representativeness after 1953 . 
No. $20 \quad 54511$ Bo1J1ng

A. Main Data Sources

1. $1841-1980$

2. $1981-1983$ (13)

B. Looation of Station. TIme standard and Times of Observation

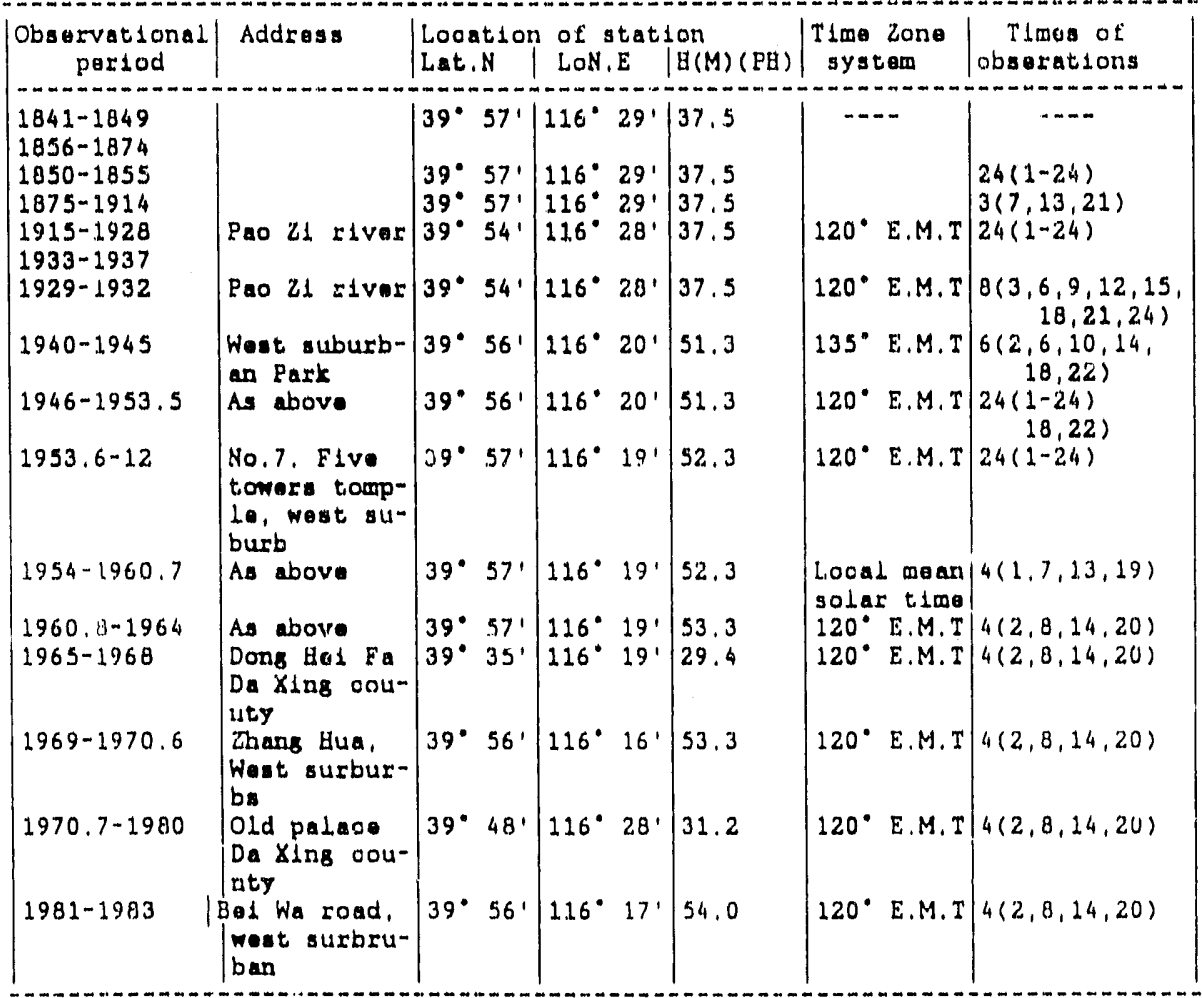

C. Numbes of Observations Used for Caloulating the Dally Moan

\begin{tabular}{|c|c|c|c|c|}
\hline Mean times & $\begin{array}{c}\text { Mean pressura } \\
\text { (Pertod) }\end{array}$ & $\begin{array}{c}\text { Temperature } \\
\text { (Perlod) }\end{array}$ & $\begin{array}{l}\text { Relative } \\
\text { humidity } \\
\text { (Poriod) }\end{array}$ & $\begin{array}{l}\text { Wind } \\
\text { (?oriod) }\end{array}$ \\
\hline \multicolumn{2}{|l|}{$\begin{array}{r}\text { (Max } 1 \text { mumtm } 1 n 1 \mid \\
\text { (mum) }) / 2 \mid\end{array}$} & $1925.1-2$ & & \\
\hline $3(6,14,22)$ & $\begin{array}{l}1975-1914 \\
1915-1929 \\
1934-1937\end{array}$ & $\begin{array}{l}1849-1849 \\
1859-1861 \\
1870-1914 \\
1868-1869\end{array}$ & $1875-1914$ & $1875-1883$ \\
\hline $\begin{array}{l}3(6,15,21) \\
6(2,6,10,14, \\
18,22)\end{array}$ & $1940-1945$ & $\begin{array}{l}1929.7 \\
1940-1945\end{array}$ & $\begin{array}{l}1930,4-12 \\
1940-1945\end{array}$ & $\begin{array}{l}1894-1895 \\
1929-1932 \\
1940-1945\end{array}$ \\
\hline $\begin{array}{l}B(3,6,9,12, \\
14,18,21,24)\end{array}$ & $1930.4-1930.12$ & $1930-1932$ & $1929-1932$ & \\
\hline $24(1-24)$ & $\begin{array}{l}1933-1936 \ldots 1937 \\
1946-1953\end{array}$ & \begin{tabular}{|l|}
$1850-1855$ \\
$1915.4-192.5$ \\
$1928,1933-1937.8$ \\
$1946-1953$
\end{tabular} & $\begin{array}{l}1915.5-1918 \\
1924-1928 \\
1933-1937 \\
1946-1953\end{array}$ & $\begin{array}{l}1918-1925-1928 \\
1935,7-1936,1942- \\
1943,1946-1953\end{array}$ \\
\hline $\begin{array}{l}4(1,7,13,19) \\
4(2,8,14,20)\end{array}$ & $\begin{array}{l}1954-1960.7 \\
1960.8-1983\end{array}$ & $\begin{array}{l}1954-1960.7 \\
1960.8-1983\end{array}$ & $\left|\begin{array}{|}1954-1960.7 \\
1960.8-1983\end{array}\right|$ & $\mid \begin{array}{l}1954 \cdot 1960.7 \\
1960.8-1983\end{array}$ \\
\hline
\end{tabular}


No. 2054511 Be1j1ng (cont.)

D. Remarks:

Date divided time: not olear during 1875-1895

$24120^{\circ} \mathrm{E}$ an time during 1915-1932

$24120^{\circ} \mathrm{E}$ mean tithe during $1934-1937$

$24120^{\circ}$ E maan time during 1946-1953

$21120^{\circ} \mathrm{E}$ moan time during 1933

$22135^{\circ} \mathrm{E}$ moicu tima durtrig 1940-1945

19 looal woun solar timo (L.M.S.T.) during 1954-1960

$20120^{\circ}$ E muna solar time inoe 1960,8 
:10. $21 \quad 54527$ TLan Jin

A. Main Data Souroms
2. $1891-1904$
2. $1891-1906,6$
3. $1904-1950$
4. $1951-1980$
5. $1981-1983$
6. 1951-1954 (prossure, tomperature, humldity, and winda) (12)
7. 1928-1936 (cloud amount)

B. Location of Station, ILtme Standard and Tlma of Observation

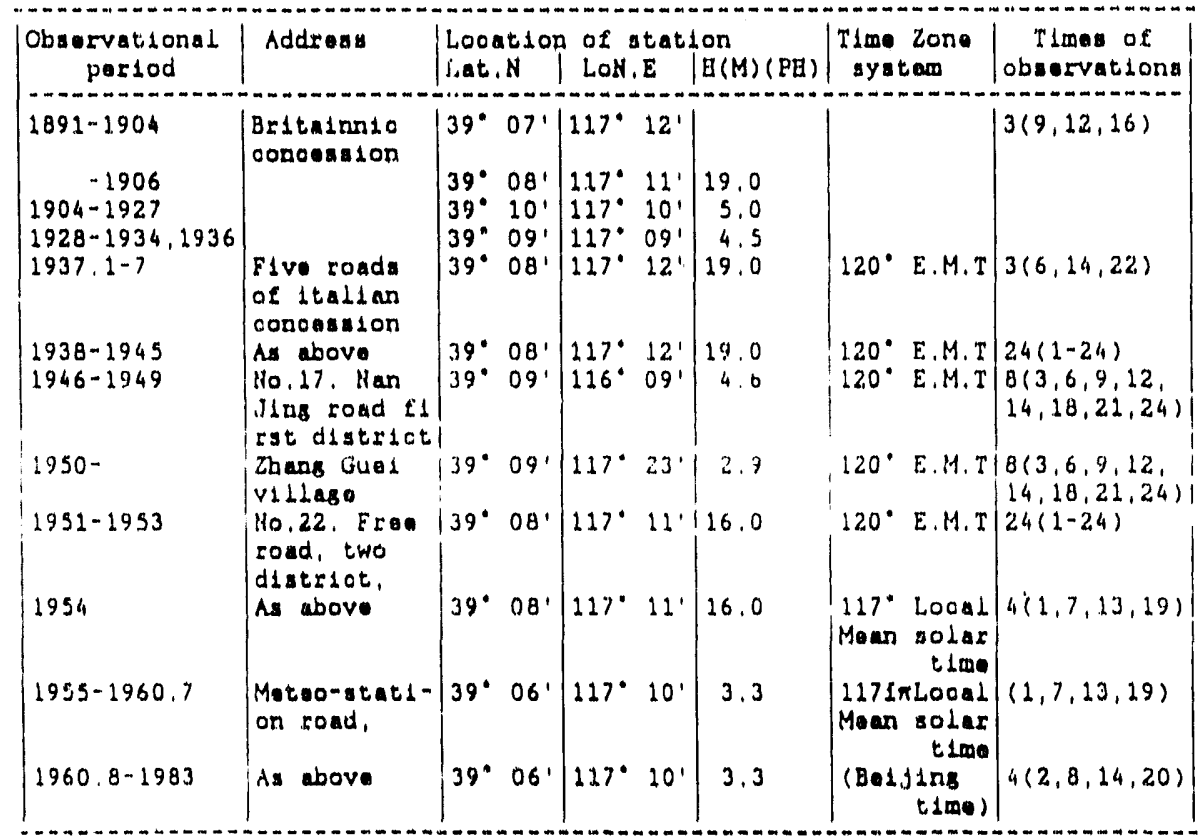

C. Number of Observations Usad for Calculating the Dadiy Maan

\begin{tabular}{|c|c|c|c|c|}
\hline Sean tidoos & $\begin{array}{l}\text { Maan pressure } \\
\text { (Porlod) }\end{array}$ & $\begin{array}{l}\text { Tomperature } \\
\text { (Porlud) }\end{array}$ & $\begin{array}{l}\text { Rolativo humlditty } \\
\text { (Poriod) }\end{array}$ & $\begin{array}{l}\text { inind } \\
\text { (Period) }\end{array}$ \\
\hline $\begin{array}{l}3(9,12,16) \\
3(6,14,22) \\
3(6,14,21) \\
3(3,6,9,12, \\
: 4,18,21,24)\end{array}$ & $\begin{array}{l}: 904-1934,1939 \\
: 946-1950\end{array}$ & $\mid \begin{array}{l}1891-1.904 \\
1904-1934,1936\end{array}$ & $1904-1934,1936$ & \\
\hline $\begin{array}{l}4(1,7,13,19) \\
4(2,8,14,20)\end{array}$ & $\begin{array}{l}193 \%-1942 \\
1944-1945 \\
1951-1953 \\
1954-1960.7 \\
1960.8-1983\end{array}$ & $\begin{array}{l}1937-1942 \\
1941-1945 \\
1951-1953 \\
1954-1960.7 \\
1960.0-1983\end{array}$ & $\left\{\begin{array}{l}1937-1942 \\
1944-1945 \\
1951-1953 \\
1954-1960.7 \\
1960.8-1983\end{array}\right.$ & $\begin{array}{l}1954-1960.7 \\
1960.8-1983\end{array}$ \\
\hline
\end{tabular}

D. Remarks: 
No, 2254602 Bau Ding

A. Main Data Souraes

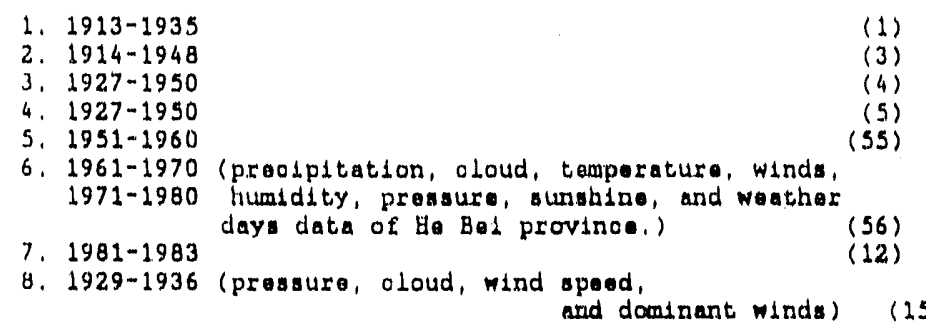

B. Looation of Station. Tlmo Standard and Ilmos of Obnervation

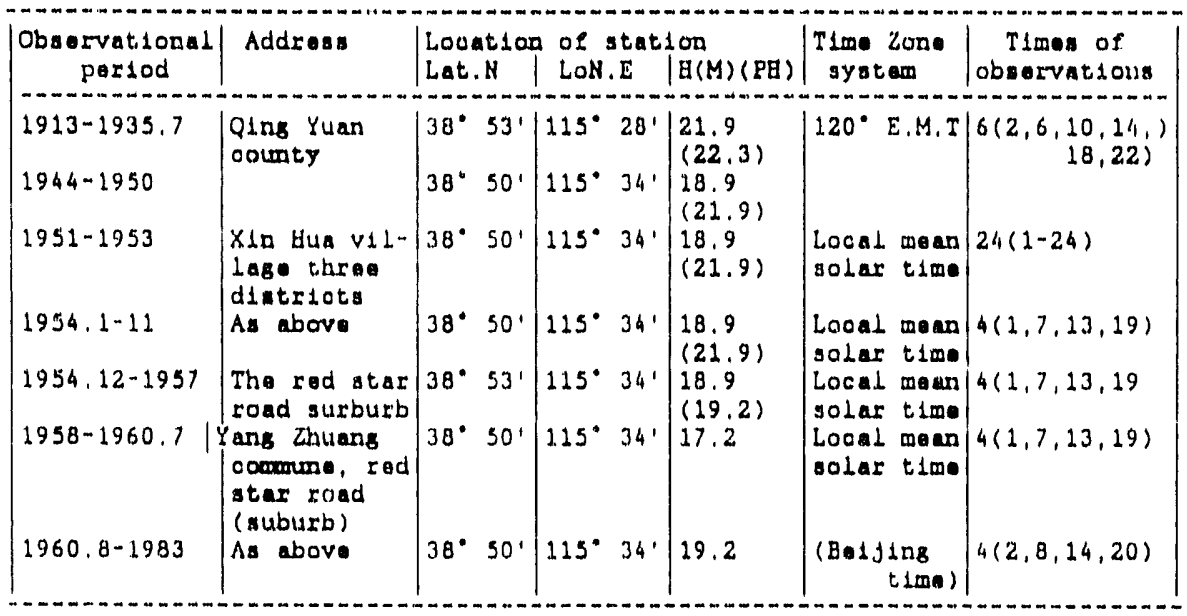

C. Numbor of Observations Usad for Caloulating the Dally Mean

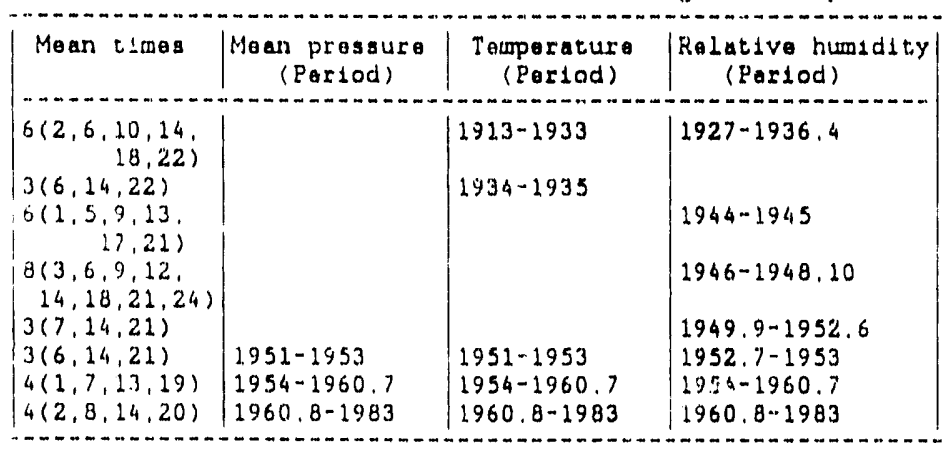

D. Remarks: 


\section{B-26}

No. 2354662 Da Lian

A. Main Data Sourcas

$\begin{array}{ll}\text { 1. } 1904-1950 & (5 \%) \\ \text { 2. } 1951-1960 & (3) \\ \text { 3. } 1961-1970 & (3) \\ \text { 4. } 1971-1980 & (60) \\ \text { 5. } 1981-1983 & (13) \\ \text { 6. } 1928-1936 \text { (cloud amount) } & (14)\end{array}$

B. Location of Station, Tlme Standard and Tlmes of Obsorvation

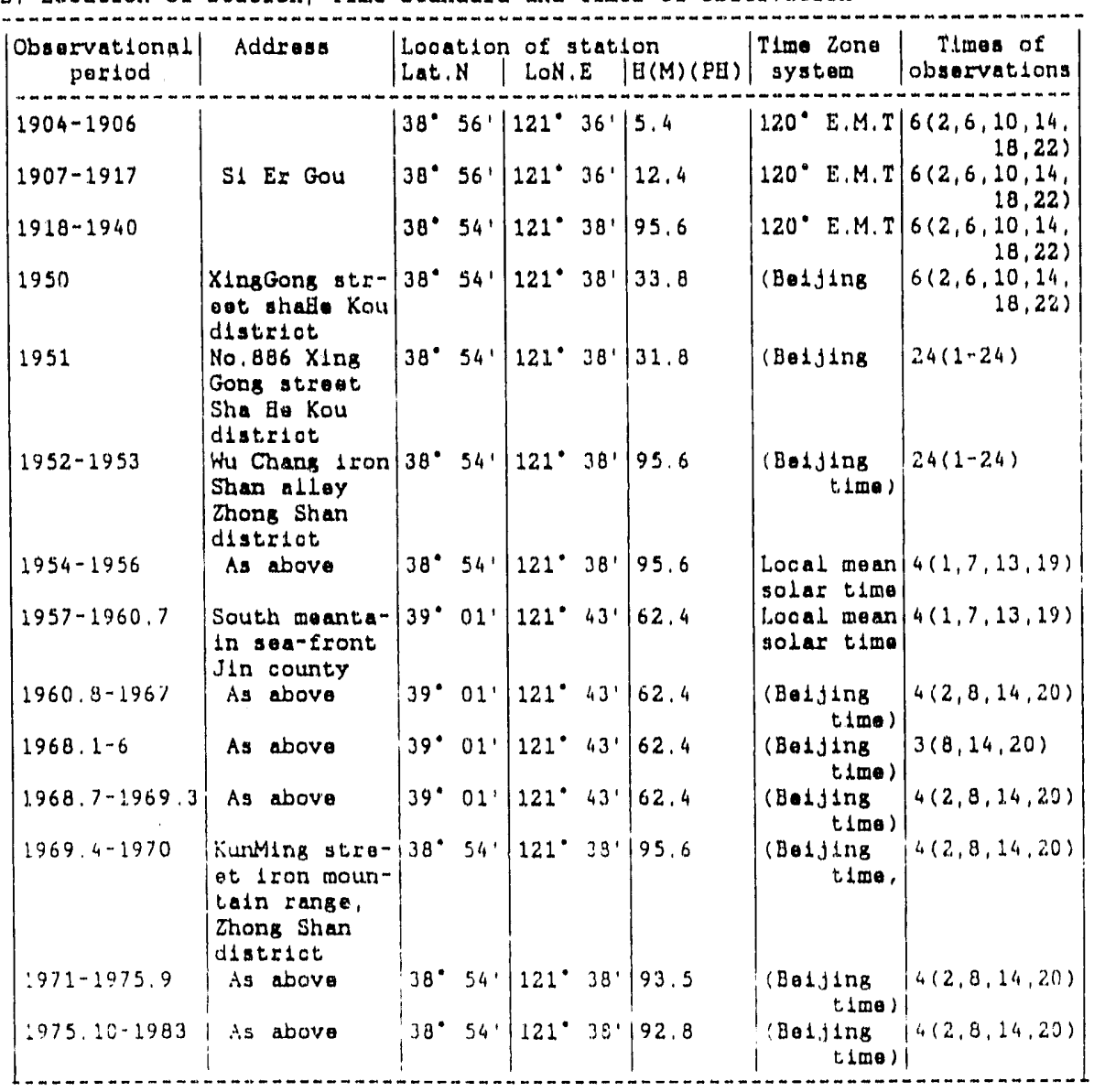

C. Number of Observations Used for Calculating tho Dally Mean

\begin{tabular}{|c|c|c|c|c|}
\hline Mean times & $\begin{array}{c}\text { Mean prosoure } \\
(\text { Porlod })\end{array}$ & $\begin{array}{c}\text { Temperature } \\
\text { (Porjod) }\end{array}$ & $\left|\begin{array}{c}\text { Relative humidity } \\
\text { (Period) }\end{array}\right|$ & $\begin{array}{c}\text { ilnd } \\
\text { (Portod) }\end{array}$ \\
\hline $\begin{array}{l}3(6,14,22) \\
6(2,6,10,14 \\
\quad 8,22) \\
24(1-24) \\
4(1,7,13,19) \\
4(2,8,14,20)\end{array}$ & \begin{tabular}{|l|}
$1934-1935$ \\
$1905-1933$ \\
$1936-1940,19.50 \mid$ \\
$1951-1953$ \\
$1954-1960.7$ \\
$1960.8-1983$
\end{tabular} \mid & $\begin{array}{l}1934-1935 \\
1905-1933 \\
1936-1940,1950 \\
1951-1953 \\
1954-1960.7 \\
1960.8-1983\end{array}$ & $\begin{array}{l}1934-1935 \\
1905-1933 \\
1936-1940,1950 \\
1951-1953 \\
1954-1960.7 \\
1960.8-1983\end{array}$ & $\begin{array}{l}1951-1953 \\
1954-1960.7 \\
1960.8-1983\end{array}$ \\
\hline
\end{tabular}

). Remarks: 
No. $24 \quad 54765$ Yan Ta1

A. Main Data Sources
1. $1886-1938$
2. $1924-1943$
(2)
3. 1907-1950
4. $1909-1936$
5. 1905-1936 (pressure)
190 : 1923 (temportura)
1928-1936 (wind speed, cloud amount) 1928-1933
6. 1937-1943
7. 1951-1960
8. 1971-1980
9. 1961-1970
10. $1981-1983$

B. Location of Station, Time Standard and Ilmes of Observation

\begin{tabular}{|c|c|c|c|c|c|c|}
\hline $\begin{array}{c}\text { Obaervational } \\
\text { period }\end{array}$ & Address & $\mid \begin{array}{l}\text { Locatid on } \\
\text { Lat.N }\end{array}$ & $\begin{array}{l}a \text { of stat: } \\
\mid \text { LoN.E }\end{array}$ & $\log (\mathrm{M})(\mathrm{PB})$ & $\begin{array}{c}\text { T1m Zono } \\
\text { system }\end{array}$ & $\begin{array}{c}\text { Times of } \\
\text { observations }\end{array}$ \\
\hline $1886-1942$ & $\begin{array}{l}\text { Chofoo } \\
\text { station }\end{array}$ & $37^{\circ} 33^{\prime}$ & $\left|121^{\circ} 22^{\prime}\right|$ & 3.0 & $120^{\circ}$ E.M.I & \\
\hline $\begin{array}{c}-1950 \\
1951.1-1952\end{array}$ & $\begin{array}{l}\text { No: } 20 \text { Broad } \\
\text { road in city }\end{array}$ & $\begin{array}{ll}37^{\circ} & 32^{\prime} \\
37^{\circ} & 36^{\prime}\end{array}$ & $\left|\begin{array}{ll}121^{\circ} & 23^{\prime} \\
121^{\circ} & 26^{\prime}\end{array}\right|$ & $\begin{array}{l}45.6 \\
12.1 \\
(13.5)\end{array}$ & $\left(\begin{array}{c}\text { Baifing } \\
\text { time })\end{array}\right.$ & $24(1-24)$ \\
\hline $1953-$ & $\begin{array}{l}\text { "Soa-front" } \\
\text { tho grape } \\
\text { mountain }\end{array}$ & $37^{\circ} 32^{\prime}$ & $121^{\circ} 24^{\circ}$ & $\begin{array}{l}46.7 \\
(47.2)\end{array}$ & 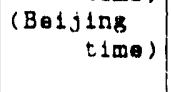 & $24(1-24)$ \\
\hline $1954-1957.5$ & $\begin{array}{l}\text { Sea-front } \\
\text { the grape } \\
\text { station }\end{array}$ & $37^{\circ} 32^{\prime}$ & $\left.121^{\circ} 24^{\prime}\right)$ & 46.7 & Local time & $4(1,7,13,19)$ \\
\hline $1957.6-11$ & As above & $37^{\circ} 32^{\prime}$ & $121^{\circ} 24^{\prime}$ & $\begin{array}{l}46.7 \\
(37.5)\end{array}$ & Local timo & $4(1,7,13,19)$ \\
\hline $1957.12-1960.6$ & As above & $37^{\circ} 32^{\prime}$ & $121^{\circ} 24^{\prime}$ & $\begin{array}{l}46.7 \\
(40.9)\end{array}$ & Local timo & $4(1,7,13,19)$ \\
\hline $1961.7-1964.8$ & As above & $37^{\circ} 32^{\prime}$ & $121^{\circ} 24^{\prime}$ & $\begin{array}{l}66.7 \\
(44.7)\end{array}$ & $\left(\begin{array}{c}\text { Beijing } \\
\text { time }\end{array}\right.$ & $4(2,8,14,20)$ \\
\hline $1964.9-1976.11$ & As above & $37^{\circ} 32^{\prime}$ & $121^{\circ} 24^{\prime}$ & $\begin{array}{l}46.7 \\
(40.9)\end{array}$ & $\begin{array}{c}(B 01 j \operatorname{lng} \\
\operatorname{time})\end{array}$ & $4(2,8,14,20)$ \\
\hline $1976.12-1983$ & As above & $37^{\circ} 32^{\prime}$ & $121^{\circ} 24^{\prime}$ & $\begin{array}{l}46.7 \\
(47.8)\end{array}$ & $\left(\begin{array}{c}\text { Boij jing } \\
\text { inde })\end{array}\right.$ & $4(2,8,14,20)$ \\
\hline
\end{tabular}

C. Number of Observations Used for Calculeting the Dally Mean

\begin{tabular}{|c|c|c|c|c|}
\hline Mean times & $\left\{\begin{array}{c}\text { Mean pressure } \\
\text { (Period) }\end{array}\right.$ & $\begin{array}{c}\text { Temperature } \\
\text { (Period) }\end{array}$ & $\begin{array}{l}\text { Relative humidity } \\
\text { (Perlod) }\end{array}$ & $\begin{array}{l}\text { Wind } \\
\text { (Poriod) }\end{array}$ \\
\hline $\begin{array}{l}(\operatorname{Max}+1 n) 1 / 2 \\
8(3,6,9,12 \\
15,18,21,24) \\
3(6,14,21) \\
3(6,14,22)\end{array}$ & & $\begin{array}{l}1924-1928 \\
1979-1933 \\
1934-1935\end{array}$ & $\begin{array}{l}1907-1936 \\
1939-1940\end{array}$ & \\
\hline $\begin{array}{l}24(1-24) \\
4(1,7,13,19) \\
4(2,8,14,20)\end{array}$ & $\begin{array}{l}1951.1-1953 \\
1954-1960.6 \\
1960.8-1983\end{array}$ & $\begin{array}{l}1951.1-1953 \\
1954-1960.6 \\
1960.8-1983\end{array}$ & $\begin{array}{l}1951.1-1953 \\
1954-1960.6 \\
1960.8-1983\end{array}$ & $\begin{array}{l}1951.1-1953 \\
1954-1960.6 \\
1960.7-1983\end{array}$ \\
\hline
\end{tabular}

D. Remarks :

2. Relative humdity data were not corrected by the pressure.

2. Old name: "chofoo" 


\section{B-28}

No. $2554823 \mathrm{Ji}$ Nan

A. Main Data Sources

$\begin{array}{ll}\text { 1. } 1916-1950 & (65) \\ \text { 2. } 1951-1980 & (66) \\ \text { 3. } 1981-1983 & (13) \\ \text { 4. } 1932-1936 & (15)\end{array}$

3. Location of Station, TIme Standard and TImes of Observations

\begin{tabular}{|c|c|c|c|c|c|c|}
\hline $\begin{array}{l}\text { Observational } \\
\text { Period }\end{array}$ & Addross & $\mid \begin{array}{l}\text { Location } \\
\text { Lat.N }\end{array}$ & $\mid$ of stat $\mid$ & $|\mathrm{B}(\mathrm{M})(\mathrm{PB})|$ & \begin{tabular}{|} 
Tlme zone \\
system
\end{tabular} & $\begin{array}{l}\text { T1mes of } \\
\text { observations }\end{array}$ \\
\hline $\begin{array}{l}1916-1920 \\
1921\end{array}$ & & $36^{\circ} 44^{\prime}$ & $117^{\circ} 08^{\prime}$ & 40.0 & $\begin{array}{l}120^{\circ} \text { E.M.T } \\
120^{\circ} \text { E.M.T }\end{array}$ & $6(2,6,10,14$; \\
\hline $1922-1931$ & & $36^{\circ} 40^{\prime}$ & $116^{\circ} 08^{\prime}$ & 42.5 & $120^{\circ}$ E.M.I & $\begin{array}{r}6(2,6,10,14 \\
18,22\end{array}$ \\
\hline $1932-1934$ & $\begin{array}{l}\text { KuIXIng but- } \\
\text { Iding south- }\end{array}$ & $36^{\circ} 40^{\prime}$ & $117^{\circ} 02^{\prime}$ & 49.4 & $120^{\circ}$ E.M.T & $\begin{array}{l}8(3,6,9,12, \\
15,28,21,24)\end{array}$ \\
\hline $1935-1937.9$ & $\begin{array}{l}\text { oast city } \\
\text { As above }\end{array}$ & $36^{\circ} 40^{\circ}$ & $117^{\circ} 02^{\prime}$ & 49.4 & $120^{\circ}$ E.M.T & $\begin{array}{l}8(3,6,9,12 \\
15,18,21,24)\end{array}$ \\
\hline $1938.5-1939$ & As above & $36^{\circ} 40^{\prime}$ & $117^{\circ} 02^{\prime}$ & 49.4 & $135^{\circ}$ E.M.T & $6(7,10,13,16$, \\
\hline $1940-1945$ & As above & $36^{\circ} 40^{\prime}$ & $127^{\circ} 02^{\prime}$ & 49.4 & $235^{\circ}$ E.M.T & $8(1,4,7,10$, \\
\hline$: 946$ & As above & $36^{\circ} 40^{\circ}$ & $117^{\circ} 02^{\prime}$ & 49.4 & $120^{\circ}$ E.M.T & $8(3,9,12,14$, \\
\hline $1947-1948$ & As abovo & $36^{\circ} 40^{\prime}$ & $117^{\circ} 02^{\prime}$ & 49.4 & $120^{\circ}$ E.M.I & $\begin{array}{r}8(3,9,12,14 \\
15,18,21,24)\end{array}$ \\
\hline $1949-$ & $\begin{array}{l}\text { Mulberry fi- } \\
\text { old, Northea- } \\
\text { st suburbs }\end{array}$ & $36^{\circ} 42^{\prime}$ & $117^{\circ} 04^{\circ}$ & 28.8 & $120^{\circ}$ E.M.T & $\begin{array}{r}8(3,9,12,14 \\
15,18,21,24)\end{array}$ \\
\hline $1950-1950.6$ & As above & $36^{\circ} 42^{\prime}$ & $117^{\circ} \mathrm{O}$ & $\begin{array}{l}28.8 \\
(29.7)\end{array}$ & $120^{\circ}$ E.M.T & $24(1-24)$ \\
\hline $2953.7-9$ & $\begin{array}{l}\text { WhYeng moun- } \\
\text { t1 an Northw- } \\
\text { est h111-top }\end{array}$ & $36^{\circ} 41^{\prime}$ & $126^{\circ} 53^{\prime}$ & $\begin{array}{l}55.7 \\
(55.7)\end{array}$ & $\begin{array}{c}(B 01 j \operatorname{sing} \\
\operatorname{tim})\end{array}$ & $16(6-21)$ \\
\hline $1.953 .10-12$ & As above & $36^{\circ} 41^{\prime}$ & $116^{\circ} 58^{\circ}$ & $\begin{array}{l}54.0 \\
(55.7)\end{array}$ & $\begin{array}{c}(B \theta 1 j \text { Ing } \\
\text { t1⿴囗十) }\end{array}$ & $16(6-21)$ \\
\hline $1.954 .1-8$ & As above & $36^{\circ} 41^{\prime}$ & $116^{\circ} 58^{\circ}$ & $\begin{array}{l}54.0 \\
(55.7)\end{array}$ & Locnl tima & $4(1,7,13,19)$ \\
\hline $1954.9-1957.6$ & As above & $36^{\circ} 41^{\prime}$ & $116^{\circ} 58^{\prime}$ & $\begin{array}{l}55.1 \\
(37.5)\end{array}$ & Local time & $4(1,7,13,19)$ \\
\hline $1957.7-1960.6$ & As above & $36^{\circ} 4 \lambda^{\prime}$ & $116^{\circ} 53^{\prime}$ & $\begin{array}{l}51.6 \\
(52.2)\end{array}$ & Local time & $4(1,7,13,19)$ \\
\hline $1960.7-1966.121$ & As above & $36^{\circ} 41^{\prime}$ & $116^{\circ} 59^{\prime}$ & $\mid \begin{array}{l}51.6 \\
(52.2)\end{array}$ & $\left|\begin{array}{c}(B \theta 1 j \operatorname{lng} \\
t \operatorname{lg\theta } \theta)\end{array}\right|$ & $4(2,8,14,20)$ \\
\hline$: 967.2-1.993$ & $A s$ adove & $36^{\circ} 41^{\prime}$ & $116^{\circ} \leq 91$ & $\begin{array}{l}\mid 51.6 \\
(57.8)\end{array}$ & $\mid \begin{array}{l}(B a d j 1 n g \\
\mid \operatorname{tim\theta })\end{array}$ & $4(2,8,14,2 . C)$ \\
\hline
\end{tabular}


$2554823 \mathrm{Ji}$ Nan (cont.)

C. Number of Observations Used for Calculating the Dally Mean

\begin{tabular}{|c|c|c|c|c|}
\hline Mean timea & $\begin{array}{c}\text { Mean prosauro } \\
\text { (poriod) }\end{array}$ & $\begin{array}{c}\text { Temperatura } \\
\text { (period) }\end{array}$ & $\begin{array}{c}\text { Relative humidity } \\
\text { (poriod) }\end{array}$ & $\begin{array}{l}\text { Wind } \\
\text { (period) }\end{array}$ \\
\hline $\begin{array}{c}3(6,14,21) \\
6(2,6,10,14, \\
18,22) \\
6(7,10,13,16, \\
19,22) \\
8(3,6,9,12, \\
14,18,21,24) \\
8(3,6,9,12, \\
15,18,21,24) \\
8(1,4,7,10,13 \\
16,19,22) \\
8(3,9,12,14, \\
15,18,21,24) \\
24(1-24) \\
4(1,7,13,19) \\
4(2,8,14,20)\end{array}$ & $\begin{array}{l}1935-1937.9 \\
1947-1949 \\
1932-1934 \\
1940-1945 \\
1946 \\
1950-1953 \\
1954.1-1960.6 \\
1960.8-1983\end{array}$ & $\begin{array}{l}1919-1920 \\
1936-1937.9 \\
1921-1931 \\
1938-1939 \\
1935,1947-1949 \\
1932-1934 \\
1940-1945 \\
1946 \\
1950-1953 \\
1954.1-1960.6 \\
1960.8-1983\end{array}$ & $\begin{array}{l}1921-1931 \\
1938,5-1938 \\
1947-1949 \\
1932-1934 \\
1940-1945 \\
1946 \\
1950-1953 \\
1954 \cdot 1-1960.6 \\
1960.8-1983\end{array}$ & $\begin{array}{l}195-1953 \\
1954.1-1960.6 \\
1960.7-1983\end{array}$ \\
\hline
\end{tabular}

D. Remarks:

1. Datn divided time: $211^{\circ} E$ mozidian time durting 1950-1953

19 local time during 1954.1-1960.6

20 Beljing time since 1960.7

2. The pressure has boen corroctad to the prosent hight. 
A. Main Data Sources
1. $1898-1950$
(67)
2. $1951-1980$
(68)
3. $1981-1983$
(13)
4. $1916-1936$
(14)
5. $1937-1943$
(62)

B. Location of Station, Time Standard and IImes of Observations

\begin{tabular}{|c|c|c|c|c|c|c|}
\hline $\begin{array}{l}\text { Obervational } \\
\text { Poriod }\end{array}$ & Addres: & $\begin{array}{l}\text { Looation } \\
\text { Lat. IN }\end{array}$ & $\mid$ a of stati & $|\mathrm{B}(\mathrm{M})(\mathrm{PB})|$ & $\begin{array}{l}\text { Tim zone } \\
\text { aystem }\end{array}$ & $\begin{array}{l}\text { TImos of } \\
\text { observations }\end{array}$ \\
\hline $1998-1899$ & $\begin{array}{l}\text { No.1 Gunntao } \\
\text { road }\end{array}$ & & & & $120^{\circ}$ E.M.T & $3(8,14,20)$ \\
\hline $\begin{array}{l}1900-1901 \\
1902-1905.5 \\
1905.6-1915\end{array}$ & $\begin{array}{l}\text { As bove } \\
\text { As above } \\
\text { South dist5- } \\
\text { 1ot Guan } x 1-\end{array}$ & $36^{\circ} 04^{\prime}$ & $120^{\circ} 19^{\prime}$ & 77.0 & 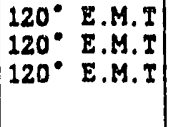 & $\begin{array}{l}3(7,14,21) \\
3(7,14,21)\end{array}$ \\
\hline $1916.6-1924.2$ & ans bild & $36^{\circ} 04^{\circ}$ & $120^{\circ} 19^{\prime}$ & 77.0 & $120^{\circ}$ E.M. I & $\begin{array}{c}3(1,5,9,13 \\
17,21)\end{array}$ \\
\hline $\begin{array}{l}1924.3-1937.8 \\
1938.6-1949\end{array}$ & As above & $\begin{array}{ll}36^{\circ} & 04^{\prime} \\
36^{\circ} & 04^{\prime}\end{array}$ & $\left|\begin{array}{ll}120^{\circ} & 19^{\prime} \\
120^{\circ} & 19^{\prime}\end{array}\right|$ & $\begin{array}{l}77.0 \\
77.0\end{array}$ & $\begin{array}{l}120^{\circ} \text { E.M.T } \\
120^{\circ} \text { E.M.T }\end{array}$ & $\begin{array}{c}24(6-21,22-5) \\
6(1,5,9,13, \\
17,21)\end{array}$ \\
\hline $1946-1950$ & As above & $36^{\circ} 04^{\prime}$ & $120^{\circ} 19^{\prime}$ & 77.0 & $120^{\circ}$ E.M.I & $\begin{array}{c}24(6-21,22-5) \\
17,21)\end{array}$ \\
\hline $1951-1953$ & $\begin{array}{l}\text { B111-top of } \\
\text { Guan Xiang }\end{array}$ & $36^{\circ} 04^{\prime}$ & $120^{\circ} 19^{\prime}$ & $\begin{array}{l}77.0 \\
(78.6)\end{array}$ & $\begin{array}{c}(B, 1 J \operatorname{lng} \\
\text { time })\end{array}$ & $24(1-24)$ \\
\hline $1954-1959$ & As above & $36^{\circ} 04^{\prime} \mid$ & $120^{\circ} 19^{\prime}$ & $\begin{array}{l}77.0 \\
(78.6)\end{array}$ & $\begin{array}{c}(B \in 1 j \operatorname{lng} \\
t \text { Ime })\end{array}$ & $4(1,7,13,19)$ \\
\hline $1960-1960.6$ & As above & $36^{\circ} 04^{\prime}$ & $120^{\circ} 19^{\prime}$ & $\begin{array}{l}77.0 \\
(78.6)\end{array}$ & $\left|\begin{array}{c}\text { (Buijing } \\
t \text { Imo })\end{array}\right|$ & $4(1,7,13,19)$ \\
\hline $1960.7-1970$ & As above & $36^{\circ} 04^{\prime}$ & $120^{\circ} 19^{\prime}$ & $\begin{array}{l}77.0 \\
(78.6)\end{array}$ & $\begin{array}{c}(B \bullet 1 j \operatorname{lng} \\
t \operatorname{Im})\end{array}$ & $4(2,8,14,20)$ \\
\hline $1971-1983$ & $\begin{array}{l}\text { South distr- } \\
\text { lot Fu Long } \\
\text { h111 (h111- } \\
\begin{aligned} \text { top) }\end{aligned}\end{array}$ & $36^{\circ} 04^{\prime}$ & $120^{\circ} 20^{\circ}$ & $\begin{array}{l}76.0 \\
(77.2)\end{array}$ & $\begin{array}{c}(B \bullet 1 j \operatorname{lng} \\
t \operatorname{lm} \theta)\end{array}$ & $4(2,8,14,20)$ \\
\hline
\end{tabular}

C. Number of Observations Used for Calculating the Dally Mean

\begin{tabular}{|c|c|c|c|}
\hline Mean times & $\left|\begin{array}{c}\text { Mean pressure } \\
\text { (period) }\end{array}\right|$ & $\begin{array}{c}\text { Temperature } \\
\text { (period) }\end{array}$ & $\begin{array}{l}\text { Relative humidity } \\
\text { (period) }\end{array}$ \\
\hline $\begin{array}{l}1(10) \\
3(8,14,20) \\
3(7,14,21)\end{array}$ & $\begin{array}{l}1914-1915.2 \\
1907-1913 \\
1915.2-12\end{array}$ & $\begin{array}{l}1898 \cdot 3-1899 \\
1902-1915\end{array}$ & $\begin{array}{l}1898.6-1899 \\
1902-1915\end{array}$ \\
\hline $\begin{array}{c}3(6,14,22) \\
6(2,6,10,14, \\
18,22) \\
24(1-24)\end{array}$ & $\begin{array}{l}1916-1924.2 \\
1938-1945 \\
1924.3-1937.5\end{array}$ & $\begin{array}{l}1940-1946.2 \\
1916-1924.2 \\
1938-1939 \\
1924.3-1937.8 \\
1900-1901 \\
1954-1960\end{array}$ & $\begin{array}{l}1940-1946.2 \\
1916-1924.2 \\
1938-1939 \\
1924.3-1937.8 \\
1900-1901\end{array}$ \\
\hline $\begin{array}{l}4(1,7,13,19) \\
4(2,8,14,20)\end{array}$ & $\begin{array}{l}1954-1960.6 \\
1960.7-1983\end{array}$ & $\begin{array}{l}1954-1960.6 \\
1960.7-1983\end{array}$ & $\begin{array}{l}1954-1960.6 \\
1960.7-1983\end{array}$ \\
\hline
\end{tabular}

D. Remarks : 
A. Maln Data Sources
1. $1935-1949$
2. 1935.7-1936 (pressure, humedity, cloud amount,
3. $1941-1949$
and wind speed) (15)
4. $1951-1960$
$1961-1970$
$1971-1975$
5. $1976-1980$
6. 1976-1980 (snow days)
1971-1980 (dominant winds)
1961-1970 (mean/max/min temperature and oloud amount) (157)
8. 1981-1983
(4)
$(69)(70)(71)$
(159)
(156)
(13)

B. Looation of Station. TIme Standard and Times of Observations

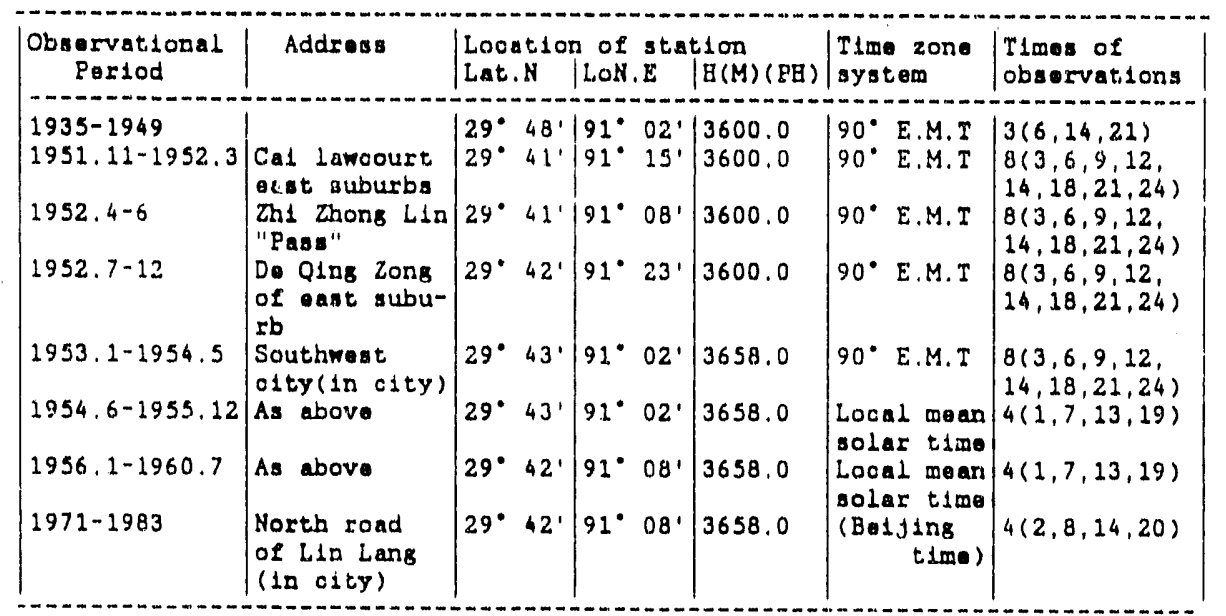

C. Number of Observationg Used for Calculating the Dadly Mean

\begin{tabular}{|c|c|c|c|c|}
\hline Mean times & $\left|\begin{array}{c}\text { Mean pressure } \\
(p e r i o d)\end{array}\right|$ & $\begin{array}{l}\text { Temporature } \\
\text { (period) }\end{array}$ & $\begin{array}{c}\text { Relative humldity } \\
\text { (period) }\end{array}$ & $\begin{array}{l}\text { Wind } \\
\text { (period) }\end{array}$ \\
\hline $\begin{array}{l}3(6,14,21) \\
9(3,6,9,12, \\
14,18,21,24)\end{array}$ & $1954.1-5$ & $\begin{array}{l}1935-1949 \\
1954,1-5\end{array}$ & $1954.1-5$ & $1954,1-5$ \\
\hline $\begin{array}{l}4(1,7,13,19) \\
4(2,8,14,20)\end{array}$ & $\left|\begin{array}{l}1954.6-1960.7 \\
1960.8-1983\end{array}\right|$ & $\begin{array}{l}1954.6-1960.7 \\
1960.8-1983\end{array}$ & $\begin{array}{l}1954.6-1960.7 \\
1960.8-1983\end{array}$ & $\begin{array}{l}1954,6-1960.7 \\
1960.8-1983\end{array}$ \\
\hline
\end{tabular}

D. Remarks :

1. Date divided time: 24-24 $90^{\circ} \mathrm{E}$ mean time during 1951.1.1-1954.5 19-19 local mean solar time (L.M.S.T) during 1954.1-1960.6 20-20 Beijing time since 1960.8 
:1o. $28 \quad 56294$ Cheng Du

A. Maln Data Sources

$\begin{array}{lr}\text { 1. } 1906-1933 & (3) \\ \text { 2. } 1932.8-1950 & (72) \\ \text { 3. } 1933-1936 \text { (pressure, cloud amount) } & (15) \\ \text { 4. } 1951-1980 & (73) \\ \text { 5. } 1951-1960 & (74) \\ \text { 6. } 1971-1980 \text { (dominant winds) } & (157) \\ \text { 5. } 1981-1983 & (13)\end{array}$

B. Location of Station, Time Stundard and TLmes of Observations

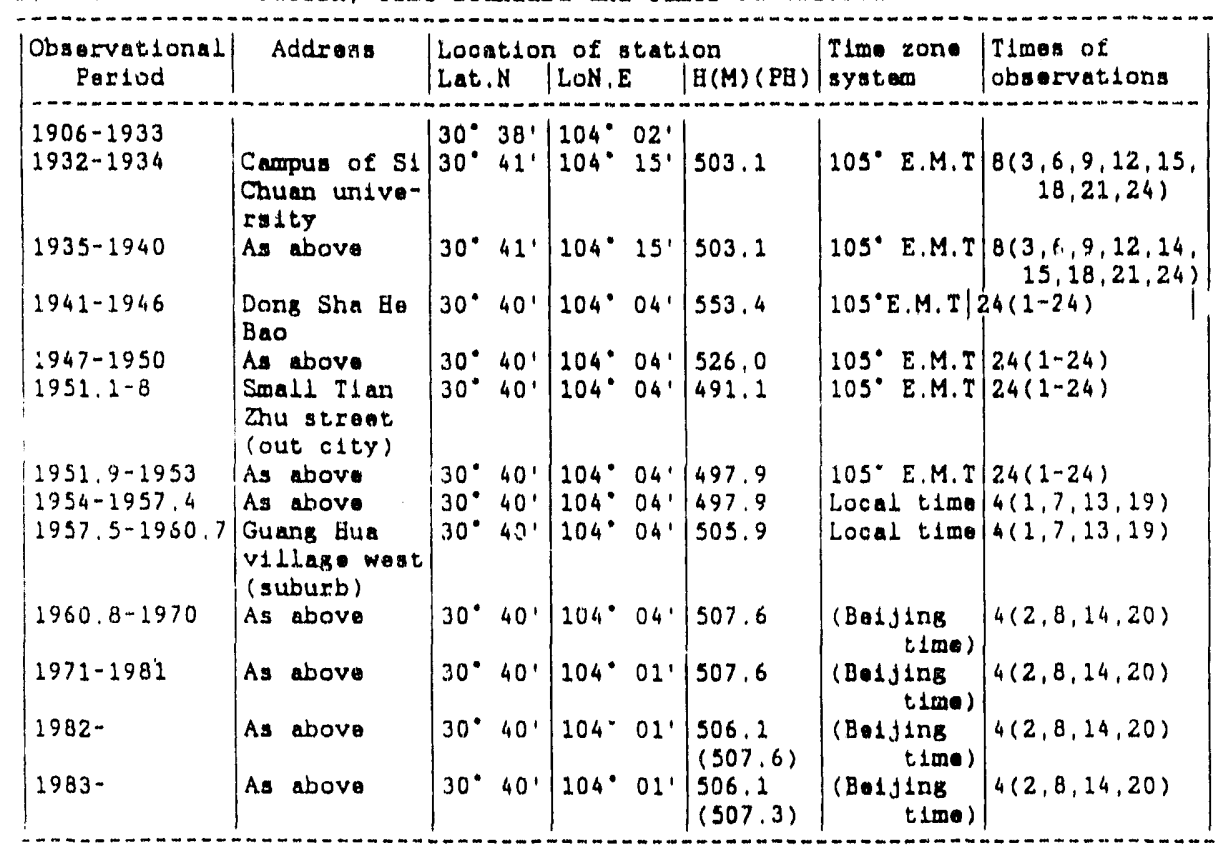

C. Ilumber of Observations Used for Calculating the Dally Mean

\begin{tabular}{|c|c|c|c|}
\hline Moan tames & $\left.\right|_{\substack{\text { Mean pressure } \\
\text { (period) }}}$ & $\begin{array}{l}\text { Temperature } \\
\text { (portod) }\end{array}$ & $\begin{array}{l}\text { Relative humidity } \\
\text { (poriod) }\end{array}$ \\
\hline $\begin{array}{l}3(6,14,21) \\
5(6,14,21) \\
24(1-24)\end{array}$ & $\begin{array}{l}1934 \\
: 735-1940 \\
1941-1942 \\
1947-1953\end{array}$ & $\begin{array}{l}1932-1934 \\
1935-1940 \\
1941-1953\end{array}$ & $\begin{array}{l}1932-1934 \\
1935-1941.2 \\
1941.3-1953\end{array}$ \\
\hline $\begin{array}{l}4(1,7,13,19) \\
4(2,8,14,20)\end{array}$ & $\begin{array}{l}1954-1960.7 \\
12960.8-1983\end{array}$ & $\begin{array}{l}1954-1960.7 \\
1960.8-1983\end{array}$ & $\begin{array}{l}1954-1960.7 \\
1960.8-1983\end{array}$ \\
\hline
\end{tabular}

D. Remariks : 
A. Maln Data Souroos
1. $1924-1950$
2. $1951-1970$
3. $1971-1980$
$(2)(3)(4)$
4. $1951-1980$
5. $\begin{array}{r}1951-1960 \\ 1971-1980\end{array}$
(75) $(76)$
(13)
(77)
. $1981-1983$
(12)
(156)
(15)

B. Looation of Station, Tluo Standard and Ilmes of Observation.

\begin{tabular}{|c|c|c|c|c|c|c|}
\hline $\begin{array}{l}\text { Obaervational } \\
\text { Perlod }\end{array}$ & Addros: & $\left|\begin{array}{l}\text { Logat } 100 \\
\text { Let.M }\end{array}\right|$ & $\mid$ Lof atati $\mid$ & fon & $\begin{array}{l}\text { T1me zone } \\
\text { aynteos }\end{array}$ & $\begin{array}{l}\text { Timen of } \\
\text { observationa }\end{array}$ \\
\hline $\begin{array}{l}1924.2-1950 \\
1938-1950 \\
1926-1935 \\
1939.3-1950.3 \\
1951.1-3\end{array}$ & 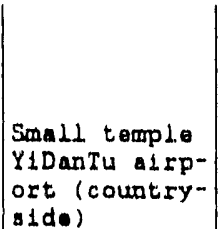 & $\mid \begin{array}{ll}27^{\circ} & 53^{\prime} \\
27^{\circ} & 53^{\prime} \\
27^{\circ} & 55^{\prime} \\
27^{\circ} & 53^{\prime} \\
27^{\circ} & 53^{\prime}\end{array}$ & $\left|\begin{array}{ll}102^{\circ} & 18^{\prime} \\
102^{\circ} & 18^{\prime} \\
102^{\circ} & 18^{\prime} \\
102^{\circ} & 18^{\prime} \\
102^{\circ} & 18^{\prime}\end{array}\right|$ & $\mid \begin{array}{c}1517.0 \\
1517.0 \\
1552.8 \\
1582.8\end{array}$ & $\begin{array}{ll}120^{\circ} & E, M, I \\
120^{\circ} & E, M, I \\
120^{\circ} & E, M, T \\
120^{\circ} & E, M, T \\
105^{\circ} & \text { E.M.T }\end{array} \mid$ & $\mid \begin{array}{l}3(6,14,21) \\
3(6,14,21) \\
3(6,14,21) \\
3(6,14,21) \\
6(6,9,12) \\
14,18,21)\end{array}$ \\
\hline $\begin{array}{l}1951.4-7 \\
1951.3-1.2 \\
1954-1960.7\end{array}$ & $\begin{array}{l}\text { As above } \\
\text { As abov } \\
\text { North towor } \\
\text { templo } \\
\text { (1n clty) }\end{array}$ & $\begin{array}{ll}27^{\circ} & 53^{\prime} \\
27^{\circ} & 53^{\prime} \\
27^{\circ} & 53^{\prime}\end{array} \mid$ & $\begin{array}{ll}102^{\circ} & 18^{\prime} \\
102^{\circ} & 02 \\
102^{\circ} & 02^{\prime}\end{array} \mid$ & $\begin{array}{l}1582.8 \\
1.582 .8 \\
1590.7\end{array}$ & $\begin{array}{l}109^{\circ} \text { E.M.I I } \\
105^{\circ} \text { E.M.I } \\
\text { Loond mean } \\
\text { solar tIme }\end{array}$ & $\begin{array}{l}24(1-24) \\
24(1-24) \\
4(1,7,13,19)\end{array}$ \\
\hline $1960-1968.6$ & As above & $27^{\circ} 53^{\prime}$ & $102^{\circ} 02^{\prime}$ & 1590.7 & $\left(\begin{array}{c}(B) 1 j 1 \mathrm{ng} \\
\text { time })\end{array}\right.$ & $4(2,8,14,2,0)$ \\
\hline $1968.7-11$ & As above & $27^{\circ} 53^{\prime}$ & $102^{\wedge} 02^{\prime}$ & 2590.7 & $\begin{array}{c}(B 01 j 108 \\
t 1 m e)\end{array}$ & $3(8,14,20)$ \\
\hline $1968.12-1978$ & As above & $27^{\circ} 53^{\prime}$ & $102^{\circ} 02^{\prime}$ & 1590.7 & $\begin{array}{c}(B 01 J 108 \\
t \text { 100 })\end{array}$ & $4(2,8,14,20)$ \\
\hline $1979-1942.3$ & As abovo & $27^{\circ} 54^{\prime}$ & $102^{\circ} 16^{\prime}$ & $\begin{array}{l}1590.7 \\
(1398.9)\end{array}$ & 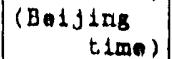 & $4(2,8,14,20)$ \\
\hline $1982,4-1983$ & As above & $27^{\circ} 54^{\prime}$ & $102^{\circ} 16^{\prime}$ & $\begin{array}{l}1590.9 \\
(1398.9)\end{array}$ & $\left|\begin{array}{c}(B \otimes 1 j \operatorname{lng} \\
t \operatorname{lme})\end{array}\right|$ & $4(2,8,14,20)$ \\
\hline
\end{tabular}

C. Niumber of Observations Used fol Calculating tho Dally Moan

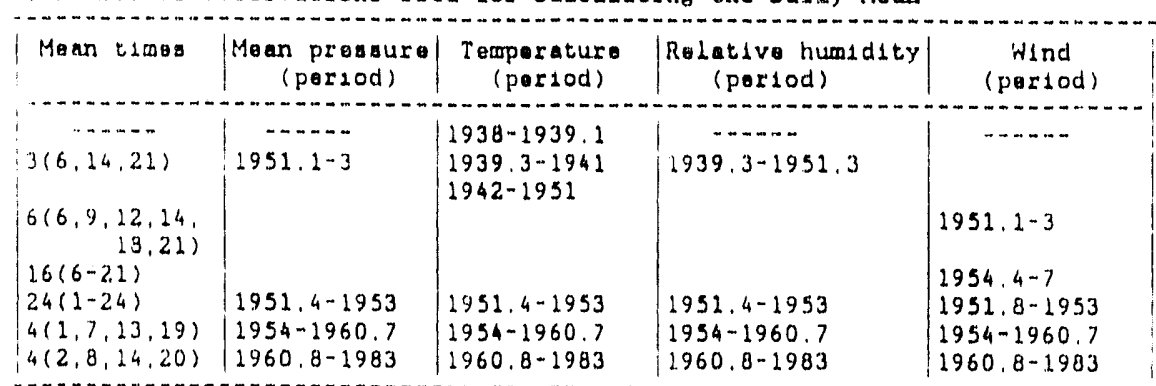

D. Recuarks

$\therefore$ Diffarences of wind direction, pressure, gtc, occur around 1954 due to a change of station location, 
No. $30 \quad 56739$ T'ang Chong

A. Main Data Sources

$\begin{array}{lc}\text { i. } 1911-1938 \text { (prociptition) } & (3)(80) \\ \text { 2. } 1916-1941 & (2) \\ \text { 3. } 1951-1980 & (78) \\ \text { 4. } 1981-1983 & (13) \\ \text { 5. } 1981-1936 & (15)\end{array}$

B. Location of Station. TImo Standard and Tlmos of Observations

\begin{tabular}{|c|c|c|c|c|c|c|}
\hline $\begin{array}{c}\text { Observationad. } \\
\text { Perlod }\end{array}$ & Address & $\left|\begin{array}{l}\text { Looation } \\
\text { Lat. N }\end{array}\right|$ & $\begin{array}{l}\text { f of stan at } \\
\text { for }\end{array}$ & $\begin{array}{l}\text { ted on } \\
\mid \mathrm{B}(\mathrm{M})(\mathrm{PB})\end{array}$ & $\begin{array}{l}\text { Tlme zone } \\
\text { system }\end{array}$ & $\begin{array}{l}\text { Tlmes of } \\
\text { abrervations }\end{array}$ \\
\hline $\begin{array}{l}1911-1932 \\
1934 \\
1932.11-1933 \\
1935-1938.10 \\
1938.11-1941 \\
1951-1953 \\
1954 \cdot 1960.7 \\
1960.8 \cdot 1983\end{array}$ & Custons & $\left|\begin{array}{ll}25^{\circ} & 00^{\prime} \\
25^{\circ} & 00^{\prime} \\
25^{\circ} & 00^{\prime} \\
25^{\circ} & 00^{\prime} \\
25^{\circ} & 00^{\prime} \\
25^{\circ} & 07^{\prime} \\
25^{\circ} & 07^{\prime} \\
25^{\circ} & 07^{\prime}\end{array}\right|$ & 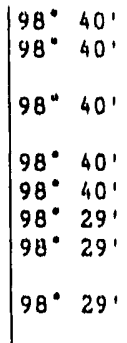 & $\mid \begin{array}{l}1633.7 \\
1633.7 \\
1633.7 \\
1633.7 \\
1633.7 \\
1647.8 \\
1647.8 \\
1647.8\end{array}$ & $\begin{array}{l}105^{\circ} \text { E.M.I } \\
120^{\circ} \text { E.M.T } \\
105^{\circ} \text { E.M.I I } \\
\text { L.ood neun } \\
\text { solar timo } \\
\text { (BoLjing } \\
\text { t.1010) }\end{array}$ & $\begin{array}{l}\text { (Maximumtond } \\
\text { mum)/2 } \\
8(3,6,9,12, \\
15,18,21,24) \\
3(6,14,21) \\
24(1-24) \\
4(1,7,13,19) \\
4(2,8,14,20)\end{array}$ \\
\hline
\end{tabular}

C. Nunber of Obrurvations Used for Caloulating the Dally Mean

\begin{tabular}{|c|c|c|c|}
\hline Mean times & $\begin{array}{c}\text { Moan prossux: } \\
(\text { pariod })\end{array}$ & $\begin{array}{c}\text { Temperature } \\
(\text { perlod })\end{array}$ & $\begin{array}{c}\text { Relative humidity } \\
\text { (period) }\end{array}$ \\
\hline $\begin{array}{c}\text { (Maximuminan } 1 \\
\operatorname{tom}) / 2 \\
8(3,6,9,12,14, \\
\quad, 8,21,24) \\
3(6,14,21) \\
8(3,6,9,12,14, \\
18,21,24) \\
4(1,7,13,19) \\
4(2,8,14,20)\end{array}$ & $\left\{\begin{array}{l} \\
1951-1953 \\
1954-1960.7 \\
1960.8-1983\end{array}\right.$ & $\begin{array}{l}1916-1932.10 \\
1938.11-1941 \\
1934 \\
1932.11-1933 \\
1935-1938.10 \\
1951-1953 \\
1954-1960.7 \\
1960.8-1983\end{array}$ & $\begin{array}{l}1951-1953 \\
1954-1960.7 \\
1960.8-1983\end{array}$ \\
\hline
\end{tabular}

D. Remarks:

C. Old name: :ang Tye 


\section{B-35}

No, 31

56778 Kun Mlng

A. Main Data Souroos
1. $1901-1936$
2. $1928 \div-1950$
3. $1951-1980$
(3)
(79)
$(78)(80)$
4. $1981-1983$
(13)

B. Location of Station. TImo Standard and TImoa of Obsorvations

\begin{tabular}{|c|c|c|c|c|c|c|}
\hline $\begin{array}{c}\text { Observationad } \\
\text { Pertod }\end{array}$ & Addroses & $\left|\begin{array}{l}\text { Looat 1on } \\
\text { Lat. N }\end{array}\right|$ & $\begin{array}{l}n \text { of atat } \\
\mid \text { LoN.E }\end{array}$ & $\begin{array}{l}10 n \\
\mid H(M)(P B)\end{array}$ & $\begin{array}{l}\text { Time zone } \\
\text { systers }\end{array}$ & $\mid \begin{array}{l}\text { Tlmos of } \\
\text { observations }\end{array}$ \\
\hline $\begin{array}{l}1901-1936 \\
1928-1936.5 \\
1936.6-1938.4\end{array}$ & 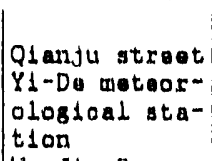 & $\left|\begin{array}{ll}25^{\circ} & 02^{\prime} \\
225^{\circ} & 03^{\prime}\end{array}\right|$ & $\mid \begin{array}{ll}102^{\circ} & 41^{\prime} \\
102^{\circ} & 42^{\prime}\end{array}$ & $\mid \begin{array}{l}1893.0 \\
1922.1\end{array}$ & $\left|\begin{array}{ll}105^{\circ} & \text { E.M.M.T } \\
105^{\circ} & \text { E.M.T }\end{array}\right|$ & $\mid \begin{array}{c}3(6,14,21) \\
24(6-21) \\
22-5)\end{array}$ \\
\hline 1946 & Wu-J1 $a-B a$ & $25^{\circ} 022^{\prime}$ & $102^{\circ} 43^{\prime}$ & 1902.0 & $105^{\circ}$ E.M.T & $8(3,6,9,12$ \\
\hline $\begin{array}{l}1947-1951.8 \\
1991.9-12 \\
1952.1-8 \\
1932.9-12 \\
1953-1960.7\end{array}$ & $\begin{array}{l}W u-J 1 a-B a \\
W u-J i a-B a \\
W u-J 1 a-B a \\
W u-J 1 a-B a\end{array}$ & $\begin{array}{ll}25^{\circ} & 02^{\prime} \\
25^{\circ} & 022^{\prime} \\
25^{\circ} & 022^{\prime} \\
25^{\circ} & 022^{\prime} \\
25^{\circ} & 01^{\prime}\end{array}$ & 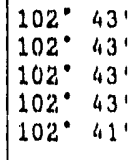 & $\begin{array}{l}1902,0 \\
1961.0 \\
1893,4 \\
1891.0 \\
1891.4\end{array}$ & $\begin{array}{l}105^{\circ} \text { E.M.T } \\
105^{\circ} \text { E.M.T } \\
105^{\circ} \text { E.M.T } \\
105^{\circ} \text { E.M.T } \\
\text { Locat mean }\end{array}$ & $\begin{array}{l}24(1-24) \\
24(1-24) \\
24(1-24) \\
24(1-24) \\
4(1,7,13,19)\end{array}$ \\
\hline $1960,8-1.983$ & & & $102^{\circ} 41^{\prime}$ & 1891.4 & 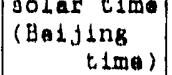 & $4(2,8,14,20)$ \\
\hline
\end{tabular}

C. Number of observations usad for caloulating tho dally mean

\begin{tabular}{|c|c|c|c|}
\hline Moan timos & $\begin{array}{c}\text { Mean pressuro } \\
\text { (pertod) }\end{array}$ & $\begin{array}{c}\text { Teaporature } \\
\text { (period) }\end{array}$ & $\begin{array}{c}\text { Relatilvo humidity } \\
\text { (por.1od) }\end{array}$ \\
\hline $\begin{array}{r}\text { (Maxtarimtand } 1 \\
\operatorname{mam}) / 2\end{array}$ & $-\cdots+\infty-\infty$ & $1921-1927$ & - n- \\
\hline $\begin{array}{l}J(6,14,21) \\
3(6,15,21) \\
24(1-24)\end{array}$ & $\begin{array}{l}1929-1938.4 \\
1946 \\
1947-19.53\end{array}$ & $\begin{array}{l}1928-1938.4 \\
1946 \\
1947-1953\end{array}$ & $\begin{array}{l}1930-1936.4 \\
1946 \\
1937-1938.4 \\
1947-1953\end{array}$ \\
\hline $\begin{array}{l}4(1,7,13,19) \\
4(2,8,14,20)\end{array}$ & $\begin{array}{l}1953-1960.7 \\
1960.8-1983\end{array}$ & $\begin{array}{l}1953-1960.7 \\
1960.8-1983\end{array}$ & $\begin{array}{l}1953-1960.7 \\
1960.8-1983\end{array}$ \\
\hline
\end{tabular}

D. Remarks: 
Ho. $32 \quad 57006$ Than shut

A. Maln Data Souroes

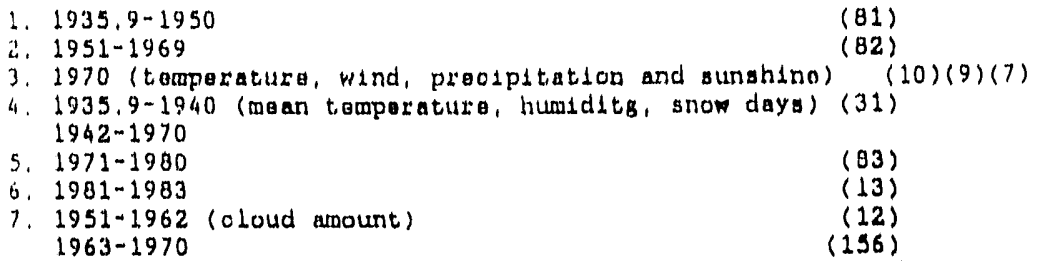

8. Looation of Station, TIme Standard and Tlmos of Observations

\begin{tabular}{|c|c|c|c|c|c|c|}
\hline $\begin{array}{l}\text { Observational } \\
\text { Porlod }\end{array}$ & Addrosu & $\left|\begin{array}{l}\text { Location } \\
\text { Lat.N }\end{array}\right|$ & $\mid$ Lof atate $\mid$ & $|\mathrm{g}(\mathrm{M})(\mathrm{PA})|$ & $\begin{array}{l}\text { Tieno zono } \\
\text { aystem }\end{array}$ & $\begin{array}{l}\text { Tlues of } \\
\text { obsorvat lons }\end{array}$ \\
\hline \begin{tabular}{|l}
$1935.9-1938.12$ \\
$1940.4-1940.11$ \\
$1942.1-1942.5$ \\
$1942.6-1944.5$
\end{tabular} & $\mid \begin{array}{l}\text { Duan } X 1 \text { Wang } \\
J 1 \text { Y } Y \\
\text { As abovo } \\
\text { As above }\end{array}$ & $\left|\begin{array}{ll}34^{\circ} & 36^{\prime} \\
34^{\circ} & 36^{\prime}\end{array}\right|$ & $\begin{array}{l}105^{\circ} \\
105^{\circ} \\
34^{\prime}\end{array}$ & $\begin{array}{l}1174.0 \\
1174.0\end{array}$ & $\left|\begin{array}{ll}120^{\circ} & \text { E.M.T. T } \\
120^{\circ} & \text { E.M.M.T } \\
120^{\circ} & \text { E.M.T. }\end{array}\right|$ & $\begin{array}{l}24(1-24) \\
7(6,9,12,14, \\
3(6,14,21) \\
5(6,9,12,18\end{array}$ \\
\hline $1945.1-7$ & As above & $34^{\circ} 36^{\prime}$ & $105^{\circ} 34^{\prime}$ & 1174,0 & $120^{\circ}$ E.M. & $\begin{array}{c}9(6,7,9,12, \\
13,14,18 .\end{array}$ \\
\hline $1945.8-1949.7$ & As abov & $34^{\circ} 36^{\prime}$ & $105^{\circ} 35^{1}$ & 1174.0 & $120^{\circ}$ E.M.T & $\begin{array}{r}6(6,9,12,15 \\
18,21)\end{array}$ \\
\hline $1949.8-1950.12$ & $\begin{array}{l}\text { Ho Nan Liang } \\
\text { J la Ping }\end{array}$ & $34^{\circ} 36^{\prime}$ & $105^{\circ} 34^{\prime}$ & 1202.1 & $120^{\circ}$ E.M.T & $\begin{array}{r}6(6,9,12,15 \\
18,21)\end{array}$ \\
\hline $1951.1-1952.5$ & As abova & $34^{\circ} 36^{\prime}$ & $105^{\circ} 34^{\prime}$ & 1225.0 & $105^{\circ}$ E.M.T & $\begin{array}{r}8(3,6,9,12, \\
15,18,21,24)\end{array}$ \\
\hline $1952.6 \cdot 1953.12$ & $\begin{array}{l}\text { Dong ErShiLI } \\
\text { Pu Zhao Jla } \\
\text { villago }\end{array}$ & $34^{\circ} 29^{\prime}$ & $106^{\circ} 01^{\prime}$ & 1096.1 & $105^{\circ}$ E.M.I & $\begin{array}{r}8(3,6,9,12 \\
15,18,21,24)\end{array}$ \\
\hline $1954.1-12$ & As above & $34^{\circ} 29^{\prime}$ & $106^{\circ} 01^{\prime}$ & 1096.1 & $\begin{array}{l}\text { Looul mean } \\
\text { sodar tione }\end{array}$ & $4(1,7,13,19)$ \\
\hline $1955.1-1960.7$ & $\begin{array}{l}\text { East outside } \\
\text { Huld } 1 \text { Pu Jing } \\
\text { Jia villago }\end{array}$ & $34^{\circ} 35^{\prime} \mid$ & $105^{n} 45^{\prime}$ & 1131.7 & $\begin{array}{l}\text { l.ocal mean } \\
\text { solar tione }\end{array}$ & $4(1,7,13,19)$ \\
\hline $1960.8 \cdot 1983$ & & $34^{\circ} 35^{\prime}$ & $105^{\circ} 45^{\prime}$ & 1131.7 & 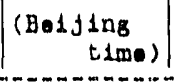 & $4(2,8,14,20)$ \\
\hline
\end{tabular}

c. Numaber of Observations Usnd for Calculating tha Dally Maan

\begin{tabular}{|c|c|c|c|c|}
\hline Wean times & $\begin{array}{c}\text { Moan preasure } \\
(\text { poriod })\end{array}$ & $\begin{array}{c}\text { Terperaturo } \\
\text { (perdod) }\end{array}$ & $\left|\begin{array}{c}\text { Rolative humidity } \\
\text { (perlod) }\end{array}\right|$ & $\begin{array}{l}\text { Wind } \\
\text { (porlod) }\end{array}$ \\
\hline $\begin{array}{l}4211 \\
.9,12, \\
221,24)\end{array}$ & $\begin{array}{l}1935.9-1950.12 \\
1951-1953\end{array}$ & $\begin{array}{l}2935.9-1950.12 \\
1951-1953\end{array}$ & $\begin{array}{l}1935.9-1950.12 \\
1951-1953\end{array}$ & $\begin{array}{l}1935.9-1950.1 \\
1951-1953\end{array}$ \\
\hline $\begin{array}{l}(1,7,13,19) \\
(2,9,14,20)\end{array}$ & $\begin{array}{l}1954.1-1960.7 \\
1960.8-1983\end{array}$ & & $\begin{array}{l}1: 954.1-1960.7 \\
11960.8 \sim 1903\end{array}$ & $\begin{array}{l}1954.141960 .7 \\
1960.8-1983\end{array}$ \\
\hline
\end{tabular}

2. Remarks :

$\therefore$ Date divided time: $22120^{\circ} \mathrm{E}$ mean time during 1935-1950

$24105^{\circ}$ E mean time during 1951-1953

19 Looal mean solar timo (L.M.S.T.) during 1954-1960.7.

20 Betijing tiche stance 1960.8 
No. $33 \quad 57036 \quad 81 \mathrm{An}$

A. Main Data Souroos

$\begin{array}{lr}\text { 1. } 1922-1950 & (84) \\ 2.1951-1960 & (85) \\ \text { 3. } 1961-1970 & (86) \\ \text { 4. } 1971-1980 & (87) \\ \text { 5. } 1981-1983 & (13) \\ \text { 6. } 1961-1970 & (197)\end{array}$

B. Loation of Station, Tlime standard and Timen of Obarvationa

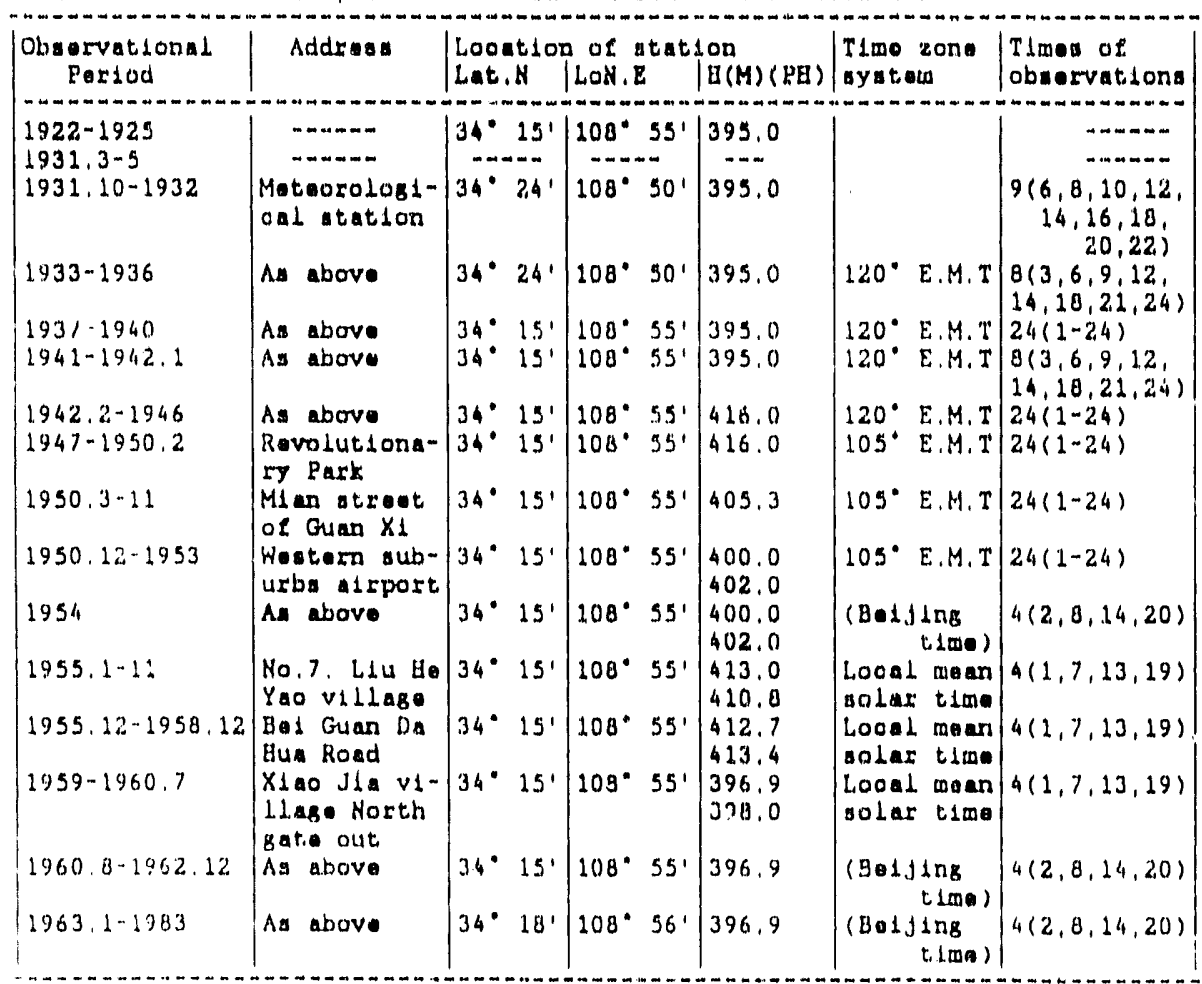

$\therefore$ Number of Observations Usad for Caloulating tha Dally Mean

\begin{tabular}{|c|c|c|c|}
\hline Mean cimes & $\begin{array}{c}\text { Mean prosaura } \\
\text { (pordod) }\end{array}$ & $\begin{array}{l}\text { Tamperatiura } \\
\text { (portod) }\end{array}$ & $\begin{array}{l}\text { Relative humidity } \\
\text { (pertod) }\end{array}$ \\
\hline $\begin{array}{c}6(6,9,12,: 5 \\
\vdots 8,21) \\
9(6,8,10,12,14, \\
16,18,20,22) \\
8(3,6,9,12,15 \\
18,21,24)\end{array}$ & $1931-1933$ & $\begin{array}{l}1922-1925 \\
1931-1933 \\
1931.3-5 \\
1931,10-1932 \\
1933\end{array}$ & $1931-1933$ \\
\hline $\begin{array}{l}3(6,14,21) \\
24(1-24) \\
4(1,7,23,19) \\
4(2,8,14,2.0)\end{array}$ & $\begin{array}{l}1934-1950,11 \\
1950,12-1953 \\
1955-1960.7 \\
1954,1960,8-1983\end{array}$ & $\begin{array}{l}1934-1936 \\
1950.12-1953 \\
1955-1960.7 \\
1954,1960.8-1983\end{array}$ & $\begin{array}{l}1934-1936 \\
1950.12-1953 \\
1955-1960.7 \\
1954.1960 .8-1983\end{array}$ \\
\hline
\end{tabular}

i. Remarys 
No. $34 \quad 37003$ Zhang zhou

A. Main Data Sollidoa
1. $1930-1939$
2. $1935-1950$
3. $1951-1960$
4. $1961-1962$
$1963-1957$
5. $1971-1900$
6. $1981-1983$
7. $1952,12-1953$

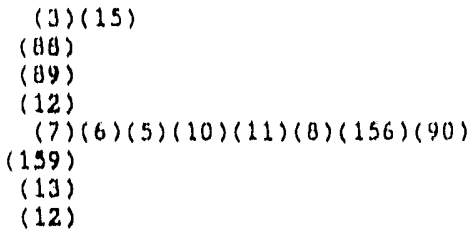

B. Looation of station, T'Ima Standard and Tlmas of Oboervationa

\begin{tabular}{|c|c|c|c|c|c|c|}
\hline $\begin{array}{c}\text { Obuervationad } \\
\text { Periud }\end{array}$ & Addrass & $\left|\begin{array}{l}\text { Loontilon } \\
\text { Lut, N }\end{array}\right|$ & $\mid$ of statif $\mid$ & $\begin{array}{l}\operatorname{lon} \\
\operatorname{la}(M)(P H)\end{array}$ & $\begin{array}{l}\text { Tlan zono } \\
\text { ayatom }\end{array}$ & $\begin{array}{l}\text { Times of } \\
\text { observations }\end{array}$ \\
\hline $\begin{array}{l}1930-1935.5 \\
1935,6-1938,5\end{array}$ & the LI P.1. & $\left|\begin{array}{ll}34^{\circ} & 35^{\prime} \\
34^{\circ} & 30^{\prime}\end{array}\right|$ & $\left|\begin{array}{ll}113^{\circ} & 40^{\prime} \\
113^{\circ} & 35^{\prime}\end{array}\right|$ & $\begin{array}{l}107.0 \\
107.0\end{array}$ & $\left|\begin{array}{ll}120^{\circ} & \text { E.M.M. } \\
120^{\circ} & \text { E.M. T }\end{array}\right|$ & $\theta(3,6,9,12$, \\
\hline $1950.5-12$ & $\begin{array}{l}\text { out of east } \\
\text { olty }\end{array}$ & $34^{\circ} 45^{1}$ & $113^{\circ} 35^{\prime}$ & 80,6 & $120^{\circ}$ E,M.T & $24(6-21,22-5)$ \\
\hline $1951-1953$ & $\begin{array}{l}\text { Eantom aub- } \\
\text { urb a.trport }\end{array}$ & $34^{\circ} 45^{\prime}$ & $113^{\circ} 35^{\prime}$ & 00,6 & $120^{\circ}$ E, M, I & $24(1-2.4)$ \\
\hline $\begin{array}{l}1954 " \\
1959-1960.6\end{array}$ & $\begin{array}{l}\text { Au above } \\
\text { Q1u villaso } \\
\text { of oaAbart } \\
\text { nuburb }\end{array}$ & $\begin{array}{ll}34^{\circ} & 63^{\prime} \\
34^{\circ} & 43^{\prime}\end{array} \mid$ & $\begin{array}{l}113^{\circ} 35^{\prime} \\
113^{\circ} 39^{\prime}\end{array}$ & $\begin{array}{l}80.6 \\
109.0\end{array}$ & $\begin{array}{l}120^{\circ} \text { E, M, T } \\
\text { Lood thoan } \\
\text { solar tedmo }\end{array}$ & $\begin{array}{l}4(2,8,14,20) \\
4(1,7,13,19)\end{array}$ \\
\hline $1,960,7$ & As abovo & $34^{\circ} 43^{\prime}$ & $113^{\circ} 39^{\prime}$ & 109.0 & $\left(\begin{array}{c}\text { (Bolj } \operatorname{lng} \\
t \lg \theta)\end{array}\right.$ & $4(2,0,14,20)$ \\
\hline $1971-1483$ & As abovu & $34^{\circ} 43^{\prime}$ & $113^{\circ} \mathrm{J9}$ & 110.4 & $\left|\begin{array}{c}(8+1) \ln 8 \\
\operatorname{tim} \theta)\end{array}\right|$ & $4(2,0,14,20)$ \\
\hline
\end{tabular}

C. Number of Observations Used for Caloulatiag the Dally Mean

\begin{tabular}{|c|c|c|c|c|}
\hline Mean timea & $\left|\begin{array}{c}\text { Menn presururo } \\
\text { (partod) }\end{array}\right|$ & $\begin{array}{l}\text { Tomperature } \\
\text { (pertod) }\end{array}$ & $\mid \begin{array}{c}\text { Rolative humidity } \\
\text { (poriod) }\end{array}$ & $\begin{array}{l}\text { Wind } \\
\text { (partod) }\end{array}$ \\
\hline $\begin{array}{l}3(6,14,21) \\
24(1-24) \\
4(1,7,13,19) \\
4(2,8,14,20) \\
4(2,8,14,20)\end{array}$ & $\begin{array}{l}1935.6-1937 \\
1938.1-5 \\
1950.5-1953 \\
1955.1-1960.6 \\
1954 \\
11960.7-1983\end{array}$ & $\begin{array}{l}1939.6-1937 \\
1938,1-5 \\
1950,5-1953 \\
1955.1-1960.6 \\
1954 \\
1960,7-1983\end{array}$ & $\begin{array}{l}1935.6-1937 \\
1938.1-5 \\
1950.5-1993 \\
1955.1-1960.6 \\
1954 \\
1960,7-1983\end{array}$ & $\begin{array}{l}1950.3-1953 \\
1959.1-1960.6 \\
1954 \\
1960.7-1983\end{array}$ \\
\hline
\end{tabular}

D. Ranarks:

Tho data at $2200-500$ hours ware taken from nutographio rucords. 
No. $35 \quad 57127$ Han Zhong

A. Maln Data Souroes

1. $1935-1990$
2. $1951-1960$
3. $1961-1970$
4. $1971-1980$
3. $1981-1983$
6. $1999-1936$ (dominarit winds)

$(3)(2)(4)$

(91)

$(6)(7)(8)(9)(10)(11)(156)$

$(159)(92)$

(13)

(12)

B. Location of Station, TIme Standard and Tluas of Obascrations

\begin{tabular}{|c|c|c|c|c|c|c|}
\hline $\begin{array}{l}\text { Obunrvat 1enal } \\
\text { Partod }\end{array}$ & Address & $\begin{array}{l}\text { Looatior } \\
\text { Lat.H }\end{array}$ & f of : tat & $\operatorname{lon}_{(M)}(\mathrm{PQ})$ & $\begin{array}{l}\text { Tlmo zone } \\
\text { ayatiom }\end{array}$ & $\begin{array}{l}\text { Tlmes of } \\
\text { obsuervations }\end{array}$ \\
\hline $\begin{array}{l}1935-1 \\
1932-1950 \\
1951-1952.1 \\
1952.2-1953\end{array}$ & & $\mid \begin{array}{ll}32^{\circ} & 56^{\prime} \\
33^{\circ} & 0.51^{\prime} \\
33^{\circ} & 05^{\prime} \\
33^{\circ} & 05^{\prime}\end{array}$ & $\left|\begin{array}{ll}107^{\circ} & 12^{\prime} \\
107^{\circ} & 04^{\circ} \\
107^{\circ} & 10^{\prime} \\
107^{\circ} & 10^{\prime}\end{array}\right|$ & $\begin{array}{c}520.0 \\
510.1 \\
(511.4) \\
510.1\end{array}$ & $\begin{array}{l}120^{\circ} \text { E.M.T } \\
120^{\circ} \text { E.M.T } \\
100^{\circ} \text { E.M.T } \\
105^{\circ} \text { E.M.T }\end{array}$ & $\begin{array}{l}3(6,14,21) \\
3(6,14,21) \\
\theta(3,6,9,12, \\
14,18,21,24) \\
24(1-24)\end{array}$ \\
\hline $1954-1956.6$ & & $33^{\circ} 05^{\prime}$ & $107^{\circ} 10^{\prime}$ & $\begin{array}{c}(511.4) \\
510.1 \\
(511.4)\end{array}$ & $105^{\circ}$ E.M.I & $24(1-24)$ \\
\hline $1957.1-5$ & & $33^{\circ} 00^{\prime}$ & $1107^{\circ} 16^{\circ}$ & $\begin{array}{l}604.0 \\
(604.8)\end{array}$ & (BojJ1ng & $4(2,8,14,20)$ \\
\hline $1957.6 \cdot 1960.7$ & & $33^{\circ} 00^{\prime}$ & $107^{\circ} 16^{\prime}$ & $\begin{array}{c}300.3 \\
(309.1)\end{array}$ & Local tidou & $4(1,7,13,19)$ \\
\hline $1960.0-1962$ & & $33^{\circ} 00^{\prime}$ & $107^{\circ} 16^{\prime}$ & $\begin{array}{l}684.0 \\
(509.1)\end{array}$ & $(B \in 1 j \operatorname{ng})$ & $4(2,8,14,20)$ \\
\hline $1963-1979$ & & $33^{\circ} 04^{\prime}$ & $107^{\circ} 12^{\prime}$ & $\begin{array}{c}508.3 \\
(509.1)\end{array}$ & (Bodj1ng & $4(2,8,14,20)$ \\
\hline $1980-1983$ & & $33^{\circ} 04^{\circ}$ & $107^{\circ} 12^{\prime}$ & $\mid \begin{array}{c}508.4 \\
(309.1)\end{array}$ & $\begin{array}{c}(B, j g 1 n g \\
t \perp \infty \theta)\end{array}$ & $4(2,8,14,20)$ \\
\hline
\end{tabular}

C. Number of Observations Usod for Caleulating the Ually Muan

\begin{tabular}{|c|c|c|c|}
\hline Moan tiloes & $\left|\begin{array}{c}\text { Hean prousure } \\
\text { (porlod) }\end{array}\right|$ & $\begin{array}{l}\text { Tetuperature } \\
(\text { por lod })\end{array}$ & $\begin{array}{l}\text { Rolatdva humidity } \\
\text { (porlod) }\end{array}$ \\
\hline $3(6,14,21)$ & & $1935-1950$ & $\begin{array}{l}1935.6-1945 \\
1948.10 * 1949.8\end{array}$ \\
\hline $\begin{array}{l}8(3,6,9,12 \\
14,18,21,24)\end{array}$ & $1951-1952.1$ & $1951-1952.1$ & 1751.1 \\
\hline $\begin{array}{l}24(1-24) \\
4(1,7,13,19) \\
4(2,8,14,20) \\
4(2,8,14,20)\end{array}$ & $\begin{array}{l}1952.2-1953 \\
1954-1960.7 \\
195 \% .1-5 \\
1960.8-1983\end{array}$ & $\begin{array}{l}1952.2-1953 \\
1954-1960.7 \\
1957.1-5 \\
1960.8=1983\end{array}$ & $\begin{array}{l}1951.2-1954 \\
1954-1960.7 \\
1957.1-5 \\
1960.8-1983\end{array}$ \\
\hline
\end{tabular}

D. Remarks:

$\therefore$ Date divided titoe: $24105^{\circ} \mathrm{E}$ inean time during 1951-1953

19 Local tiun during $1994-1960.7$

20 Beljing time sine 1960,8 
No. $36 \quad 57461 \quad$ Y1 Chang

A. Main Duta Sourous

1. $1882,7-1950$

2. 1.928-1936 (prassure, humidtty, winds, oloud amourt) (15)

3. $1951-1980$

4. $1981-1983$

$(94)$

5. $1951-1953$

(13)

(12)

B. Looation of Station, TIme Standard and TImes of Obsarvations

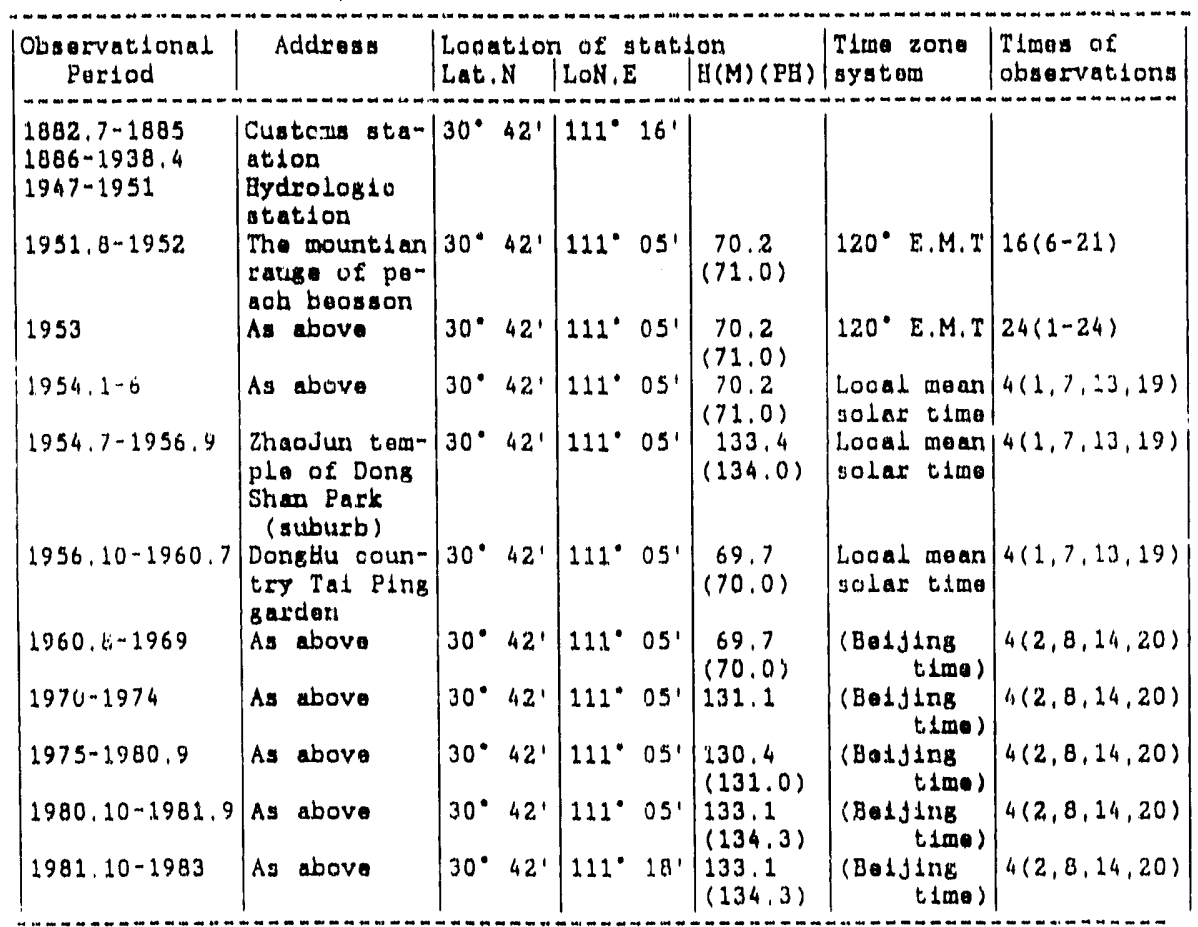

C. Number of Observations Used for Caloulating the Dally Mear

\begin{tabular}{|c|c|c|c|c|}
\hline Mean times & $\left|\begin{array}{c}\text { Moan pressure } \\
(\text { pertod })\end{array}\right|$ & $\begin{array}{c}\text { Temperature } \\
\text { (poriod) }\end{array}$ & $\begin{array}{l}\text { Rolative hurnidity } \\
\text { (poriod) }\end{array}$ & $\begin{array}{l}\text { Wind } \\
(p \in s 10 d)\end{array}$ \\
\hline $\begin{array}{l}\text { (Maximumrtins } \\
3(6,14,21) \\
24(1-24) \\
4(1,7,13,19) \\
4(2,8,14,20)\end{array}$ & $\left\{\begin{array}{l}1951.8-1953 \\
1954-1960.7 \\
1960.8-1983\end{array}\right.$ & $\begin{array}{l}1924-1933 \\
1934-1938 \\
1951.8-1953 \\
1954-1960.7 \\
1960.8-1983\end{array}$ & $\begin{array}{l}1931,8-1953 \\
1934-1960,7 \\
1960,8-1983\end{array}$ & $\begin{array}{l}1951.8-1953 \\
1954-1960.7 \\
1960.8-1983\end{array}$ \\
\hline
\end{tabular}

D. Remarks:

$\therefore$ Date divided time: Hot clear bofore 1951

$21120^{\circ} \mathrm{E}$ moan time during 1951-1952

$24120^{\circ}$ E moan time during 1953

19 Local moan solar time (L.M.S.T.) during 1954-1960,7

20 Beijing timo sinoe 1960.8 


\section{B-41}

No. $37 \quad 57494$ Wh Ban

A. Main Data Sources

$\begin{array}{ll}\text { 1. } 1880-1950 & (95) \\ \text { 2. } 1951-1980 & (96) \\ \text { 3. } 1981-1983 & (13) \\ \text { 4. } 1930-1936 \text { (cloud amount) } & (15) \\ 1937-1943 \text { (cloud amount) } & (62)\end{array}$

B. Location of Station, TIme Standard and Tlmes of Oburvations.

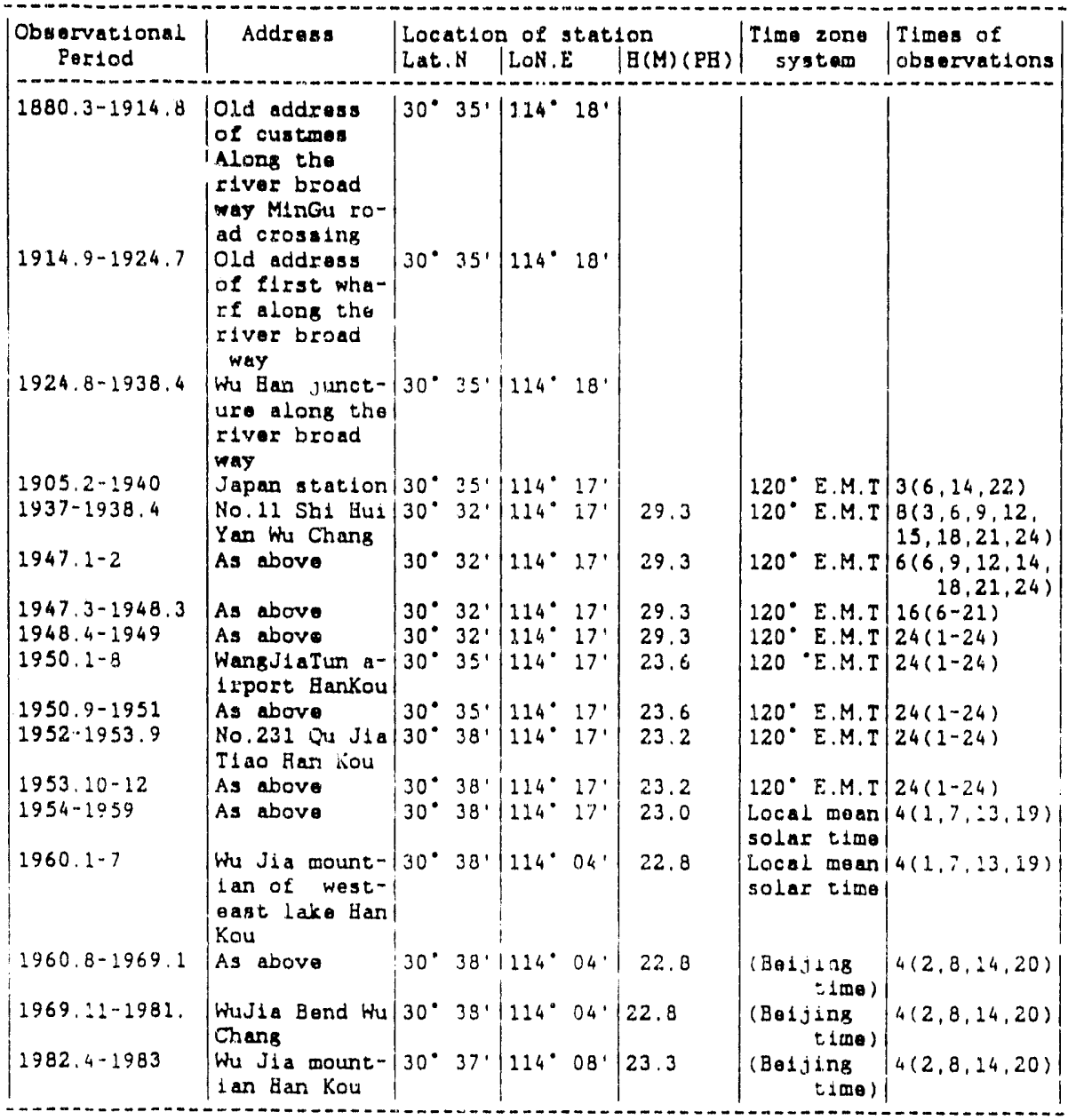


No. 3757494 the Ean (cont.)

C. Number of Observations Used for Calculating the Deily Mean

\begin{tabular}{|c|c|c|c|c|}
\hline Moan titnes & $\mid \begin{array}{c}\text { Mean pressure } \\
\text { (Perlod) }\end{array}$ & $\mid \begin{array}{r}\text { Temperatura } \\
\text { (Eeriod) }\end{array}$ & $\begin{array}{l}\text { Relative } \\
\text { humidity } \\
\text { (Perlod) }\end{array}$ & $\begin{array}{l}\text { Wind } \\
\text { (Yeriod) }\end{array}$ \\
\hline $\begin{array}{l}8(3,6,9,12,15 . \\
18,21,24) \\
3(6,14,21) \\
6(6,9,12,14 \\
18,21) \\
16(6-21) \\
24(1-24)\end{array}$ & $\mid \begin{array}{l}1950.2-12 \\
1906.7-1927.3 \\
1927.5-1936 \\
1939-1940 \\
1947.1-2\end{array}$ & $\mid \begin{array}{l}1950.2-12 \\
1906.7-1927.3 \\
1927.5-1936 \\
1939-1940 \\
1937-1938.4 \\
1947.1-2\end{array}$ & $\begin{array}{l}1905.2-12 \\
1906.7-1927.3 \\
1927.5-1936 \\
1939-1940 \\
1937-1938.4\end{array}$ & $\begin{array}{l}1947.1-1947.2 \\
1947.3-1948.3 \\
1905-1940 \\
1948.4-1949 \\
1950-1953 \\
1954-1960.7 \\
1960.8-1983\end{array}$ \\
\hline
\end{tabular}

D. Remarks :

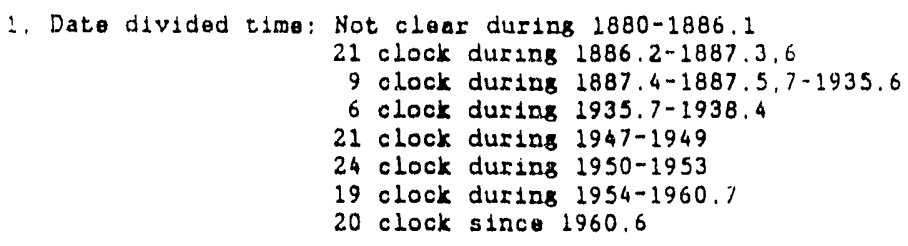

2. Date divided time: Not cloar during 1880-1886.1 21 clock during 1886.2-1887.3,6$$
9 \text { clock during 1887.4-1887.5,7-1935.6 }
$$$$
6 \text { clock during 1935.7-1938.4 }
$$$$
21 \text { clock during 1947-1949 }
$$$$
24 \text { clock during 1950-1953 }
$$$$
19 \text { clock during 1954-1960.7 }
$$$$
20 \text { clock since } 1960.6
$$

2. The procipitation data was takon form customs station during 1880-1949. 
No. 3857516 ChongQ1ng ShaPingBa

A. Main Data Sources

$\begin{array}{lr}\text { 1. } 1891-1950 & (97) \\ \text { 2. } 1928-1936 & (15) \\ \text { 3. } 1951-1980 & (98) \\ \text { 4. } 1981-1983 & (13) \\ \text { 5. } 1951-1960 \text { (dominant winds) } & (99) \\ \text { 6. } 1961-1980 \text { (dominant winds) } & (156)\end{array}$

B. Location of Station, TIme Standard and TImes of Observations.

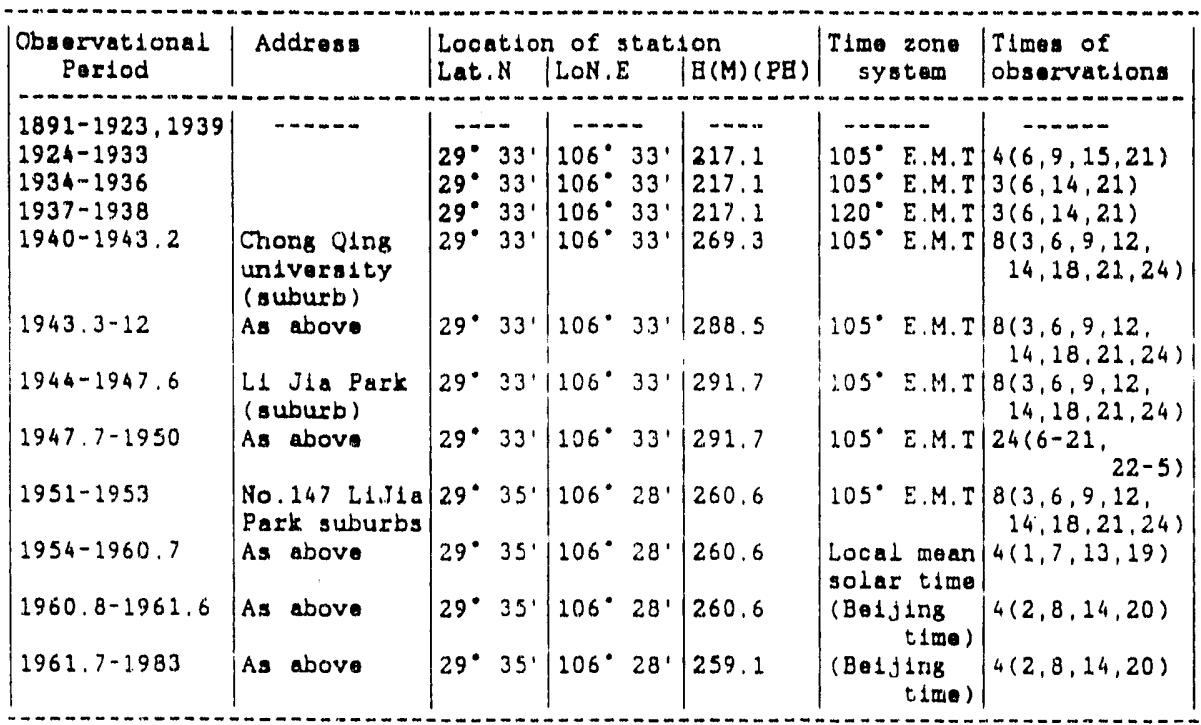

C. Number of Observations Used for Calculating the Dally Mean

\begin{tabular}{|c|c|c|c|}
\hline Mean times & $\left\{\begin{array}{c}\text { Mean pressure } \\
\text { (Pertod) }\end{array}\right.$ & $\begin{array}{r}\text { Temperatura } \\
\text { (Period) }\end{array}$ & $\begin{array}{l}\text { Rolat 1vo } \\
\text { humidity } \\
\text { (Foriod) }\end{array}$ \\
\hline 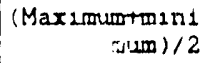 & $\cdots$ & $1924-1928$ & -.... \\
\hline $3(6,24,21)$ & $\begin{array}{l}1934-1938 \\
1940-1947\end{array}$ & $\begin{array}{l}1934-1938 \\
1940-1947\end{array}$ & $\begin{array}{l}1934-1938 \\
1940-1947\end{array}$ \\
\hline $\begin{array}{l}3(6,15,21) \\
4(6,9,15,21)\end{array}$ & $\cdots$ & $1929-1933$ & $1929-1933$ \\
\hline $\begin{array}{l}24(1-24) \\
8(3,6,9,12,14, \\
\quad 18,21,24)\end{array}$ & $\begin{array}{l}1948-1950 \\
1951-1953\end{array}$ & $\begin{array}{l}1948-1950 \\
1951-1953\end{array}$ & $\begin{array}{l}1948-1950 \\
1951-1953\end{array}$ \\
\hline $\begin{array}{l}4(1,7,23,19) \\
4(2,8,24,20)\end{array}$ & $\begin{array}{l}1954-1960.7 \\
1960.8-1983\end{array}$ & $\begin{array}{l}1954-1960.7 \\
1960.8-1983\end{array}$ & $\begin{array}{l}1954-1960.7 \\
1960.8-1983\end{array}$ \\
\hline
\end{tabular}

D. Remarks: 


\section{B-44}

Ho. 3957679 Chang Sha

A. Main Data Sourcos
1. $1909-1950$
2. $1932-1950$
$(100)(3)$
3. $1951-1980$
(101)
4. $1981-1983$
(102)
5. $1928-1936$
(13)
(15)

B. Location of Station, TIme Standard and Times of Observations.

\begin{tabular}{|c|c|c|c|c|c|c|}
\hline $\begin{array}{l}\text { Observational } \\
\text { Pertod }\end{array}$ & Addross & $\mid$\begin{tabular}{l|} 
Looution \\
Lat.N
\end{tabular} & $\begin{array}{l}n \text { of statid } \\
\mid \text { LoN. }\end{array}$ & on $(M)(P B)$ & $\begin{array}{c}\text { TIme zone } \\
\text { system }\end{array}$ & $\begin{array}{l}\text { T1mes of } \\
\text { observations }\end{array}$ \\
\hline $1909-1938$ & $\begin{array}{l}\text { Motmorologi- } \\
\text { cal station } \\
\text { cusmo: }\end{array}$ & $28^{\circ} 12^{\prime} \mid$ & $1212^{\circ} 47^{\prime}$ & 60.0 & & \\
\hline $1932.8-1938.7$ & T1anXin Park & $28^{\circ} 13^{\prime} \mid$ & $112^{\circ} 46^{\prime}$ & 90.0 & $120^{\circ}$ E.M.T & $\begin{array}{c}8(3,6,9,12, \\
15,18,21,24)\end{array}$ \\
\hline $1938.8-1948.1$ & $\begin{array}{l}\text { Dong Tang of } \\
\text { Southern mo- } \\
\text { uth out }\end{array}$ & $28^{\circ} 13^{\prime}$ & $112^{\circ} 46^{\prime}$ & 60.0 & $120^{\circ}$ E.M.T & $\begin{array}{l}8(3,6,9,12, \\
15,18,21,24)\end{array}$ \\
\hline $1948.2-12$ & $\begin{array}{l}\text { The srave of } \\
\text { a rovolutio- } \\
\text { nnary martyr } \\
\text { Xlang Qlag } \\
\text { road }\end{array}$ & $28^{\circ} \quad 13^{\prime}$ & $112^{\circ} 46^{\prime}$ & 55.0 & $120^{\circ}$ E.M.T & $\begin{array}{l}8(3,6,9,12 \\
\quad 15,18,21,24)\end{array}$ \\
\hline $1949-1950.7$ & $\begin{array}{l}\text { Arwy roud } \\
\text { side }\end{array}$ & $28^{\circ} 15^{\prime}$ & $112^{\circ} 50^{\prime}$ & 60.0 & $120^{\circ} E, M . I$ & $\begin{array}{r}8(3,6,9,15 \\
18,21,24)\end{array}$ \\
\hline $1950.8-1951$ & $\begin{array}{l}\text { No. } 94 \text { Army } \\
\text { road side }\end{array}$ & $28^{\circ} 15^{\prime}$ & $112^{\circ} 50^{\prime}$ & 60.0 & $120^{\circ}$ E.M.T & $24(1-24)$ \\
\hline 1952.1 & As above & $28^{\circ} 15^{\prime}$ & $1.12^{\circ} 50^{\prime}$ & 60.0 & $\begin{array}{c}(B) \perp j \text { ing } \\
\text { time })\end{array}$ & $24(1-24)$ \\
\hline 1952.2 & As above & $28^{\circ} 15^{\prime}$ & $112^{\circ} 50^{\circ}$ & 60.0 & $\begin{array}{c}(B \boxminus j \text { Ing } \\
\text { timo })\end{array}$ & $24(1-24)$ \\
\hline $1952.3-5$ & As abovo & $28^{\circ} 15^{\prime}$ & $112^{\circ} 50^{\circ}$ & 60.0 & $\begin{array}{c}(B \cdot 1 \mathrm{j} \operatorname{ing} \\
t 1 \infty 0)\end{array}$ & $24(1-24)$ \\
\hline $1952.6-1953$ & As above & $28^{\circ} 15^{\prime}$ & $112^{\circ} 50^{\prime}$ & 50.0 & $\begin{array}{c}(B \cdot 1 j \operatorname{lng} \\
\text { time })\end{array}$ & $24(1-24)$ \\
\hline 1954.1 & $\begin{array}{l}Y \text { ang Jia mo- } \\
\text { untian rango } \\
\text { of } X 1 \text { ao Guan } \\
\text { gate out }\end{array}$ & $28^{\circ}: 15^{\prime}$ & $112^{\circ} \leq 0^{\prime} \mid$ & 48.0 & Looal tima & $4(1,7,13,19)$ \\
\hline $\begin{array}{l}1954.2-1955.9 \\
1955.10-1956.1 \\
1956.11 .1960 .7\end{array}$ & $\begin{array}{l}\text { As above } \\
\text { As above } \\
\text { A1 uJ1 aoTang }\end{array}$ & $\begin{array}{ll}28^{\circ} & 15^{\prime} \\
28^{\circ} & 15^{\prime} \\
28^{\circ} & 15^{\prime}\end{array}$ & $\begin{array}{l}112^{\circ}=0^{\prime} \mid \\
1122^{\circ} \leq 0^{\prime} \\
1122^{\circ} \\
50^{\prime}\end{array}$ & $\begin{array}{l}48.6 \\
48.0 \\
81.3\end{array}$ & $\begin{array}{l}\text { Local time } \\
\text { Local time } \\
\text { Local time }\end{array}$ & $\begin{array}{l}4(1,7,13,19) \\
4(1,7,13,19) \\
4(1,7,13,19)\end{array}$ \\
\hline & $\begin{array}{l}\text { of rainflow- } \\
\text { er parvilic- } \\
\text { en south ga- } \\
\text { te out }\end{array}$ & & & & & \\
\hline $2960.8-1963$ & As above & $28^{\circ} 15^{\prime}$ & $112^{\circ} \leq 0^{\circ}$ & 81.3 & $\left(\begin{array}{c}\text { Baijjing } \\
\text { tima }\end{array}\right.$ & $4(2,8,14,20)$ \\
\hline $1964-1983$ & $\begin{array}{l}\text { FuYuan } 21 \text { of } \\
\text { east county } \\
\text { mountian ra- } \\
\text { nge agricul- } \\
\text { tural fleld }\end{array}$ & $28^{\circ} 12^{\prime}$ & $113^{\circ} 05^{\prime}$ & 44.9 & $\begin{array}{c}(B \operatorname{lol} \operatorname{lng} \\
\operatorname{tima} \theta\end{array}$ & $4(2,8,14,20)$ \\
\hline
\end{tabular}

C. Number of Observations Used for Calculating the Dally Mean

\begin{tabular}{|c|c|c|c|c|}
\hline Mean times & $\left\{\begin{array}{c}\text { :ean pressure } \\
\text { (Pertod) }\end{array}\right.$ & $\left\{\begin{array}{r}\text { Temperature } \\
(\text { Pertod) }\end{array}\right.$ & $\begin{array}{l}\text { Rolative } \\
\text { humidity } \\
\text { (Pariod) }\end{array}$ & $\begin{array}{l}\text { Wind } \\
\text { (Period) }\end{array}$ \\
\hline $\begin{array}{r}\text { (Maximumrtnini } \\
\text { mum) } / 2 \\
3(3,6,9,12,2= \\
23,21,24)\end{array}$ & $12932.8-1950.7$ & $\begin{array}{l}1924-1928 \\
1920-1933\end{array}$ & $\begin{array}{l}: 932.4-1.938 .7 \\
1946.4-1949.3 \\
1946.10-1950.7\end{array}$ & \\
\hline $\begin{array}{l}3(6,14,21) \\
24(1-24) \\
4(1,7,13,19) \\
4(2,8,14,20)\end{array}$ & $\begin{array}{l}1950.8-19.53 \\
1954-1960.7 \\
11950.8-1983\end{array}$ & $\begin{array}{l}1933-1950 \\
1951-1953 \\
1954-1960.7 \\
1960.8-1983\end{array}$ & $\begin{array}{l}1950.8-1953 \\
1954-1960.7 \\
1960,8-1983\end{array}$ & $\begin{array}{l}1950.8-1953 \\
1954-1960.7 \\
1960.8-1983\end{array}$ \\
\hline
\end{tabular}




\section{B-45}

No. 3957679 Chang Shu (cont.)

D. Remarks

1. Before 1948.2, pressure was a.ways corrected to 60 meters elevation.

2. During 1951-1983, pressure ras reduced by $3.5 \mathrm{mb}$ to adjust for the lower station elevation. 


\section{B-46}

No, $40 \quad 57745$ ZhI Jlang

A. Maln Data Sources
1. $1938-1949$
2. $1951-1980$
(3) (2)(4)
(103)
(13) (104)

B. Location of Station, IIme Standard and Tlues of Obsorvations.

\begin{tabular}{|c|c|c|c|c|c|c|}
\hline $\begin{array}{l}\text { Observational } \\
\text { Period }\end{array}$ & Addrass & $\begin{array}{l}\text { Loout 1or } \\
\text { Lat.N }\end{array}$ & $\begin{array}{l}\text { a of stat } \\
\text { LoN.E }\end{array}$ & $\begin{array}{l}\text { lon } \\
\mid B(M)(P B)\end{array}$ & $\begin{array}{c}\text { Time zane } \\
\text { system }\end{array}$ & $\left|\begin{array}{l}\text { Tlmes of } \\
\text { observations }\end{array}\right|$ \\
\hline $1938.6-1948.3$ & $\begin{array}{l}\text { GuJla garden } \\
\text { of wost gate } \\
\text { out }\end{array}$ & $27^{\circ} 28^{\prime}$ & $109^{\circ} 54^{\prime}$ & 251.9 & $120^{\circ}$ E.M.I & $3(6,14,21)$ \\
\hline $1948.4-1949.3$ & $\begin{array}{l}\text { Boushalong of } \\
\text { river west }\end{array}$ & $27^{\circ} 27^{\prime}$ & $109^{\circ} 38^{\prime}$ & $\ldots . . .-1$ & $120^{\circ}$ E.M.T & $3(6,14,21)$ \\
\hline $\begin{array}{l}1949.4-1950.12 \\
1951-1953\end{array}$ & $\begin{array}{l}\text { Thongsha Park } \\
\text { North of atr- } \\
\text { port East ga- } \\
\text { to out }\end{array}$ & $\begin{array}{l}27^{\circ} 27^{\prime} \\
27^{\circ} 27^{\prime}\end{array}$ & $\begin{array}{l}109^{\circ} 38^{\prime} \\
109^{\circ} 38^{\prime}\end{array}$ & 266.5 & $\begin{array}{l}120^{\circ} \text { E.M.T } \\
120^{\circ} \text { E.M.T }\end{array}$ & $\begin{array}{l}3(6,14,21) \\
8(3,6,9,12 \\
14,18,21,24)\end{array}$ \\
\hline $1954-1955.10$ & $\begin{array}{l}\text { North of alr- } \\
\text { port East ga } \\
\text { to out }\end{array}$ & $27^{\circ} 27^{\prime}$ & $109^{\circ} 38^{\prime}$ & 266.5 & Local t 1 ma & $4(1,7,13,19)$ \\
\hline $\begin{array}{l}1955.11-1960 \\
1961-1971\end{array}$ & $\begin{array}{l}\text { As above } \\
\text { North of air- } \\
\text { port East Ba- } \\
\text { tout }\end{array}$ & $\begin{array}{l}27^{\circ} 27^{\circ} \\
27^{\circ} 27^{\prime}\end{array}$ & $\begin{array}{l}109^{\circ} 29^{\circ} \\
109^{\circ} \\
28^{\circ}\end{array}$ & $\begin{array}{l}266.5 \\
266.5\end{array}$ & $\begin{array}{c}\text { Local timal } \\
\text { (Beijing } \\
\text { tima) }\end{array}$ & $\begin{array}{l}|4(1,7,13,19)| \\
|4(2,8,14,20)|\end{array}$ \\
\hline $1972-1973.12$ & $\begin{array}{l}\text { Long Jing Po } \\
\text { of North gate } \\
\text { out (b111 top) }\end{array}$ & $27^{\circ} 27^{\circ}$ & $109^{\circ} 38^{\prime}$ & 271.9 & $\begin{array}{c}(B, \mathcal{J} \operatorname{ing} \\
\operatorname{tima} \theta\end{array}$ & $4(2,8,14,20)$ \\
\hline $1973.12-1976$ & As above & $27^{\circ} 27^{\prime}$ & $109^{\circ} 38^{\prime}$ & 272.2 & $\begin{array}{c}(B \otimes 1 j \text { ing } \\
\text { tino) }\end{array}$ & $4(2,8,14,20)$ \\
\hline $1977-1983$ & As above & $27^{\circ} 27^{\circ}$ & $109^{\circ} 41^{\prime}$ & 271.9 & $\begin{array}{c}(B, j j \operatorname{ng} \\
t, 1 \text { mo })\end{array} \mid$ & $4(2,8,14,20)$ \\
\hline
\end{tabular}

C. Number of Observations lised for Calculating the Daily Mean

\begin{tabular}{|c|c|c|c|}
\hline Menn Times & $\begin{array}{c}\text { Mean prossure } \\
\text { (Perlod) }\end{array}$ & $\mid \begin{array}{r}\text { Temperatura } \\
\text { (Poriod) }\end{array}$ & $\mid \begin{array}{l}\text { Relative } \\
\text { humidity } \\
\text { (Perlod) }\end{array}$ \\
\hline $3(6,14,21)$ & ......... & $1938-1949$ & $\left\{\begin{array}{l}1938.6-1949.4 \\
1950.6-1950.12\end{array}\right.$ \\
\hline $\begin{array}{l}24(1-24) \\
4(4,7,13,19) \\
4(2,8,14,20)\end{array}$ & $\begin{array}{l}1951-1953 \\
1954-1960 \\
1961-1983\end{array}$ & $\begin{array}{l}1951-1953 \\
1954-1960 \\
1961-1983\end{array}$ & $\begin{array}{l}1951-1953 \\
1954-1960 \\
1961-1983\end{array}$ \\
\hline
\end{tabular}

כ. Remarks : 


\section{B-47}

No, 4157816 Gu1 Yang

A. MaIn Data Sourcas

$\begin{array}{lr}\text { 1. } 1920-1950 & (105) \\ 2,1951-1960 & (12) \\ \text { 3. } 1961-1970 & (106) \\ \text { 4. } 1971-1980 & (107) \\ \text { 5. } 1981-1983 & (13) \\ \text { 6. } 1961-1970 & (157) \\ \text { 7. } 1933-1936 & (15)\end{array}$

B. Looation of Station, TImu Standard and I'lwas of Obsurvations,

\begin{tabular}{|c|c|c|c|c|c|c|}
\hline $\begin{array}{l}\text { Obsorvational } \\
\text { Period }\end{array}$ & Addresa & $\left|\begin{array}{l}\text { Looat 1on } \\
\text { Lat.N }\end{array}\right|$ & a of stat & $1 \mathrm{an}(\mathrm{M})(\mathrm{PE})$ & $\begin{array}{c}\text { TLme zono } \\
\text { Sys teta }\end{array}$ & $\mid \begin{array}{l}\text { Thes of } \\
\text { observatione }\end{array}$ \\
\hline $\begin{array}{l}1920-1935 \\
1935.11\end{array}$ & $\begin{array}{l}\text { Chong Lang } \\
\text { three plooas } \\
\text { of farthland } \\
\text { (suburb) }\end{array}$ & $\left|\begin{array}{ll}26^{\circ} & 18^{\prime} \\
26^{\circ} & 35^{\prime}\end{array}\right|$ & $\mid \begin{array}{l}106^{\circ} \\
106^{\circ} 40^{\prime} \\
40^{\prime}\end{array}$ & $\begin{array}{l}1075.0 \\
1075.0\end{array}$ & $120^{\circ}$ E.M.T & $\begin{array}{c}6(6,9,12,14 \\
10,21)\end{array}$ \\
\hline $1935.12-1936$ & As above & $26^{\circ} 35^{\prime}$ & $106^{\circ} 43^{\circ}$ & 1075.0 & $120^{\circ}$ E.M.I & $\begin{array}{l}8(3,6,9,12 \\
14,18,21,24)\end{array}$ \\
\hline $1937-1938$ & $\begin{array}{l}\text { Mulborry fi- } \\
\text { old LluGuang } \\
\text { gate out } \\
\text { (auburb) }\end{array}$ & $26^{\circ} 35^{\prime} \mid$ & $1106^{\circ} 43^{\prime}$ & 1075.0 & $120^{\circ}$ E.M.T & $24(1-24)$ \\
\hline $\begin{array}{l}1939-1946.6 \\
1946.7-1953.8\end{array}$ & $\begin{array}{l}\text { As above } \\
\text { No: } 117 \text { Xin- } \\
\text { Hua road } \\
(1 \text { o olty) }\end{array}$ & $\left|\begin{array}{ll}26^{\circ} & 35^{\prime} \\
26^{\circ} & 35^{\prime}\end{array}\right|$ & $\begin{array}{l}106^{\circ} 43^{\prime} \\
106^{\circ} 43^{\circ}\end{array}$ & $\begin{array}{l}1057.4 \\
1057.4\end{array}$ & $\begin{array}{ll}105^{\circ} & \text { E.M.T } \\
105^{\circ} & \text { E.M.T }\end{array}$ & $\begin{array}{l}24(1-24) \\
24(1-24)\end{array}$ \\
\hline $\begin{array}{l}1953.9+12 \\
1954-1960.7\end{array}$ & $\begin{array}{l}\text { As above } \\
\text { No: } 56 \text { Culfui } \\
\text { alley } \\
\text { (1n city) }\end{array}$ & $\left|\begin{array}{ll}26^{\circ} & 34^{\prime} \\
26^{\circ} & 34^{\prime}\end{array}\right|$ & $\begin{array}{l}106^{\circ} 42^{\circ} \\
106^{\circ} 42^{\circ}\end{array}$ & $\begin{array}{l}1071.0 \\
1071.2\end{array}$ & $\begin{array}{l}\log ^{\circ} \text { E.M. I } \\
\text { Local tima }\end{array}$ & $\begin{array}{l}24(1-24) \\
4(1,7,13,19)\end{array}$ \\
\hline $1960.8 \cdot 1965.3$ & As above & $26^{\circ} 34^{\prime}$ & $106^{\circ} 42^{\prime}$ & 1071.2 & 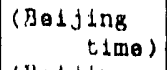 & $4(2,8,14,20)$ \\
\hline $1965.4-1983$ & As above & $26^{\circ} 35^{\prime} \mid$ & $106^{\circ} 43^{\prime}$ & 1071.2 & 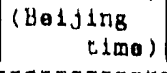 & $4(2,8,14,2$ \\
\hline
\end{tabular}

C. Humber of Obarvations Used for Calculating the Dall; fean

\begin{tabular}{|c|c|c|c|}
\hline Mean times & $\begin{array}{c}\text { Mean pressura } \\
\text { (Poriod) }\end{array}$ & $\begin{array}{l}\text { Temperatura } \\
\text { (Porlod) }\end{array}$ & $\begin{array}{l}\text { Relativo } \\
\text { humidity } \\
\text { (Perlod) }\end{array}$ \\
\hline
\end{tabular}

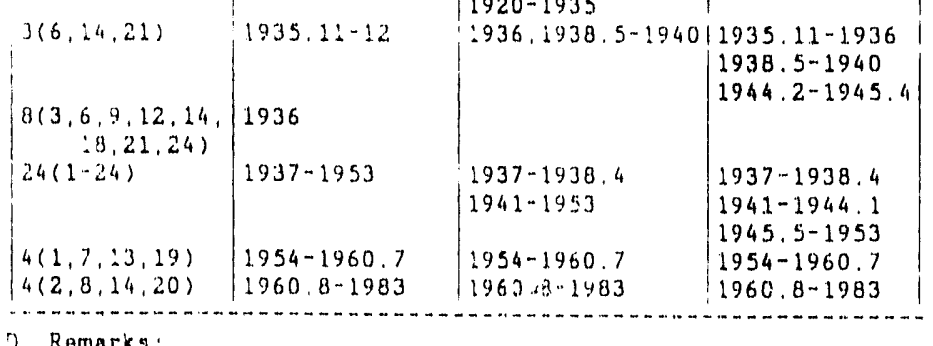


No. 4258027 Xu Zhou

A. Maln Data Souroas
1. $1915-1950$
2. $1929-1936$
3. $1951-1959$
4. $1960-1980$
5. 1981-1983
(110)
6. $1926-1973$
(13)
(111)

B. Looation of Station, TIme Standard and TImes of Observations.

\begin{tabular}{|c|c|c|c|c|c|c|}
\hline $\begin{array}{l}\text { Obaervational } \\
\text { Porlod }\end{array}$ & Addr:os: & $\mid \begin{array}{l}\text { Loontion } \\
\text { Lat.N }\end{array}$ & $\mid$ of of stat $\mid$ & $|\mathrm{H}(\mathrm{M})(\mathrm{PB})|$ & $\begin{array}{c}\text { Time zone } \\
\text { system }\end{array}$ & $\begin{array}{l}\text { Thmes of } \\
\text { observations }\end{array}$ \\
\hline $\begin{array}{l}1915-1926.5 \\
1926-1933.5\end{array}$ & $\begin{array}{l}\text { Experimental } \\
\text { whost ornp }\end{array}$ & $\left|\begin{array}{ll}34^{\circ} & 28^{\prime} \\
34^{\circ} & 17^{\prime}\end{array}\right|$ & $\left|\begin{array}{ll}217^{\circ} & 26^{\prime} \\
117^{\circ} & 10^{\prime}\end{array}\right|$ & 63.3 & (n) & $6(6,7,11,14$ \\
\hline 1934.5 & -..... & $\cdots$ & -...... & $-\ldots$ & -....... & 17.211 \\
\hline $\begin{array}{l}1933.0-12 \\
1934.1-12\end{array}$ & $\begin{array}{l}\text { As abovo } \\
\text { As above }\end{array}$ & $\begin{array}{ll}34^{\circ} & 17^{\prime} \\
34^{\circ} & 27^{\prime}\end{array}$ & $\begin{array}{ll}117^{\circ} & 10^{\prime} \\
127^{\circ} & 10^{\prime}\end{array} \mid$ & $\begin{array}{l}43.3 \\
43.3\end{array}$ & $120^{\circ}$ E.M.T & $\begin{array}{c}4(7,11,14,17) \\
6(6,7,11,14 . \\
17,19)\end{array}$ \\
\hline $\begin{array}{l}1934,4-12 \\
1935-1937\end{array}$ & $\begin{array}{l}\text { As above } \\
\text { As above }\end{array}$ & $\begin{array}{ll}34^{\circ} & 17^{\prime} \\
34^{\circ} & 17^{\prime}\end{array}$ & $\begin{array}{ll}117^{\circ} & 10^{\prime} \\
117^{\circ} & 10^{\prime}\end{array} \mid$ & $\begin{array}{l}43.3 \\
43.3\end{array}$ & $\begin{array}{l}120^{\circ} \text { E.M.T } \\
120^{\circ} \text { E.M.T }\end{array}$ & $\begin{array}{l}3(6,14,21) \\
8(3,6,9,12, \\
14,18,21,24)\end{array}$ \\
\hline $\begin{array}{l}1939-1943 \\
1949\end{array}$ & $\begin{array}{l}\text { Agrioural } \\
\text { flold of f1- } \\
\text { amer gardon } \\
\text { Bol Guan Wal } \\
\text { (Suburb) }\end{array}$ & 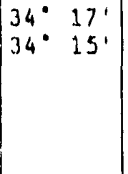 & $\begin{array}{l}117^{\circ} \\
117^{\circ} \\
14^{\prime} \\
15^{\prime}\end{array} \mid$ & $\mid \begin{array}{l}38.0 \\
44.4\end{array}$ & $120^{\circ}$ E.M.T & \\
\hline $1950-19.52$ & As above & $34^{\circ} 15^{\prime}$ & $117^{\circ} 15^{\prime}$ & 44.4 & $120^{\circ}$ E.M.T & $\begin{array}{c}8(3,6,9,12,14 \\
18,21,24)\end{array}$ \\
\hline 1953 & $\begin{array}{l}\text { Dong He v11- } \\
\text { Lage East } \\
\text { (Suburb) }\end{array}$ & $34^{\circ} 19^{\prime}$ & $117^{\circ} 22^{\circ}$ & 34.3 & $120^{\circ}$ E.M.T & \\
\hline $1954-1959$ & As above & $34^{\circ} 19^{\prime}$ & $117^{\circ} 22^{\circ}$ & 34.3 & $\begin{array}{l}\text { Local thoan } \\
\text { solar time }\end{array}$ & $4(1,7,13,19)$ \\
\hline $1960.1-7$ & & $34^{\circ} 17^{\prime} \mid$ & $117^{\circ} 18^{\prime}$ & 43.0 & $\begin{array}{l}\text { Local mean } \\
\text { solar tian }\end{array}$ & $4(1,7,13,19)$ \\
\hline $1960.8-1979$ & & $34^{\prime \prime} 17^{\prime}$ & $117^{\circ} 18^{\prime}$ & 43.0 & $\begin{array}{c}(B \cdot 1 j \operatorname{lng} \\
t i \ln n)\end{array}$ & $4(2,8,14,20)$ \\
\hline $1.980-1981.4$ & 1 & $34^{\circ} 17^{\prime}$ & $117^{\circ} 10^{\prime}$ & $\begin{array}{l}41.0 \\
(41.7)\end{array}$ & $\begin{array}{r}\text { (Budjing } \\
t \text { Ima) }\end{array}$ & $4(2,8,14,20)$ \\
\hline $1981-1983$ & & $34^{\circ} 17^{\prime}$ & $117^{\circ} 09^{\prime}$ & $\begin{array}{l}43.0 \\
(41.9)\end{array}$ & $\begin{array}{c}(B \otimes 1 j \operatorname{ng} \\
\operatorname{timo} \theta\end{array}$ & $4(2,8,14,20)$ \\
\hline
\end{tabular}

C. Ilumber of Observacions Used for Calculating the Dally Mean

\begin{tabular}{|c|c|c|c|}
\hline Mean tilmes & $\begin{array}{c}\text { Moan prosaro } \\
\text { (Porlod) }\end{array}$ & $\begin{array}{r}\text { Temperature } \\
\text { (Portod) }\end{array}$ & $\begin{array}{l}\text { Rolative } \\
\text { humadity } \\
\text { (Fortod) }\end{array}$ \\
\hline $\begin{array}{c}\text { (Max } 1 \text { mumrtm } 1)_{1} \\
\text { (num) } / 2\end{array}$ & & $1926-1928$ & \\
\hline $\begin{array}{l}5(6,7,11,14,17) \\
3(6,14,21)\end{array}$ & $1951-1953$ & $\begin{array}{l}1929-1933 \\
1934-1937.9 \\
1949.4-12 .\end{array}$ & $\begin{array}{l}1934-1937 \\
1951-1952\end{array}$ \\
\hline $\begin{array}{r}8(3,6,9,12,14 . \\
: 3,21,24)\end{array}$ & $|1935-193|$ & $1950-1953$ & $1950-1953$ \\
\hline $\begin{array}{l}4(1,7,13,19) \\
4(2,8,14,20)\end{array}$ & $\begin{array}{l}1954-1960.7 \\
: 960.8-1983 \\
1926-1934\end{array}$ & $\begin{array}{l}1954-1960.7 \\
1960.8-1983 \\
1939-1943\end{array}$ & $\begin{array}{l}1954-1960.7 \\
1960.8-1983 \\
1926-1933.1949\end{array}$ \\
\hline
\end{tabular}

). Remarks:

2. Old riame: Tong Shan 


\section{B-49}

No. 4358144 Q1ng-Jiang (Wol-Yin)

A. Main Data Souroes

1. $1913-1950$ (prooipitation)

i. 1928-1937 (touperature)

3. 1950 (humldity)

(111)

4. $1932-1950$

5. $1951-1980$

(4)

6. $1981-1983$

B. Looation of Station. TIme Standard and TImes of Observations.

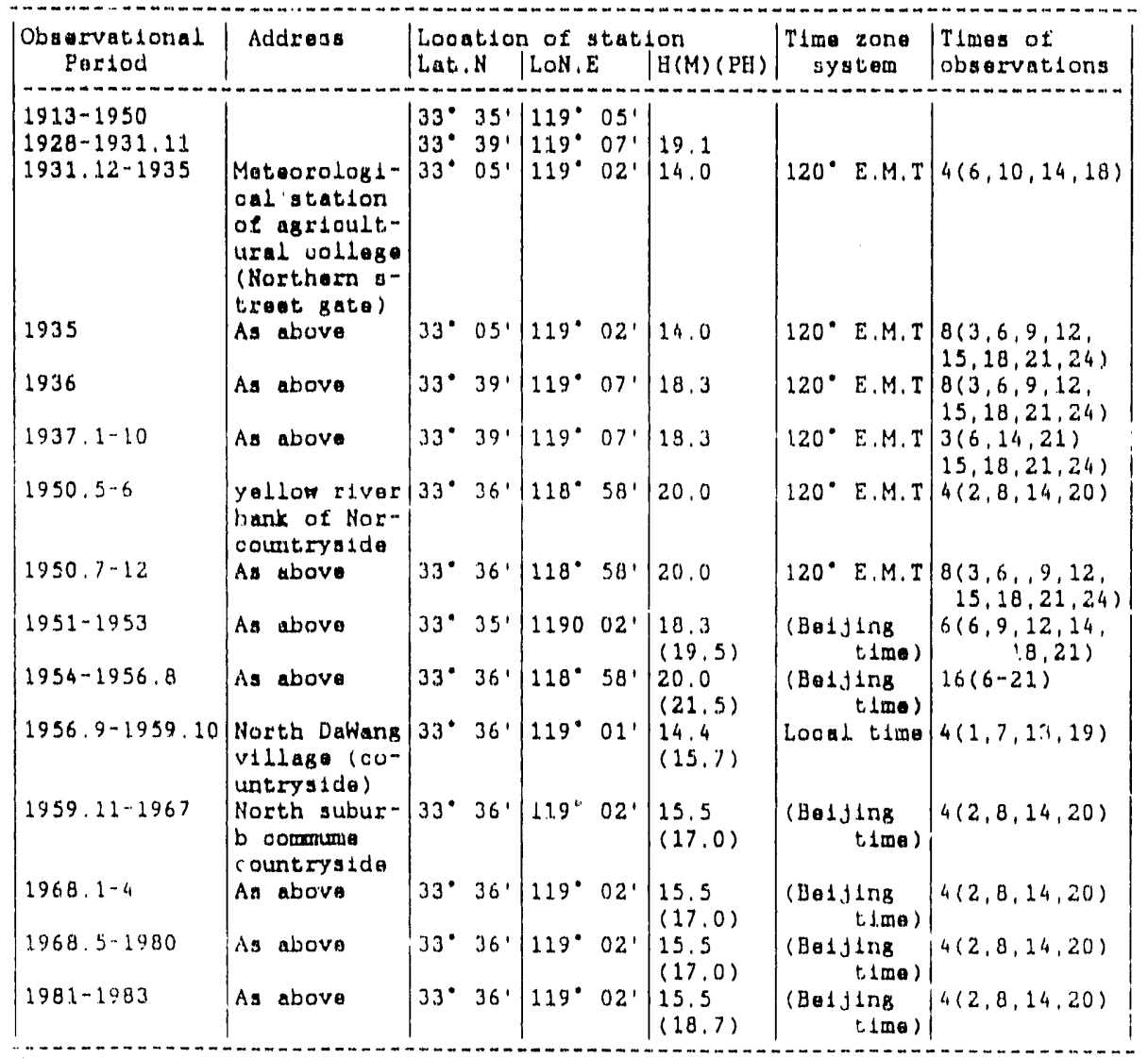

C. Rumber of Observations Used for Calculating the Dally Mean

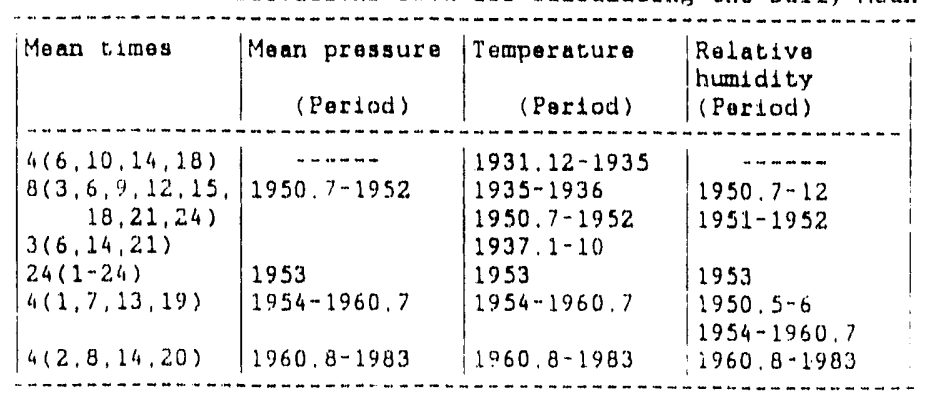

D. Rerrarks :

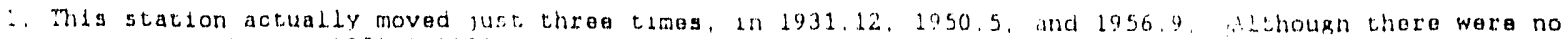
st.ation moves during 1954.1-:956.3, a change of measurenent tocmique resultad in new assigneents of congltude, latitude and olevation. 
A. Main Data Souroas
1. $1905-1950$
(113)
$1905-1970$
(114)
$1963-1972$
(111)
2. $1971-1980$
(115)
3. $1971-1980$
4. $1908-1928$
(13)

B. Lovation of Station. Time Standard and Tlmes of Ohservations.

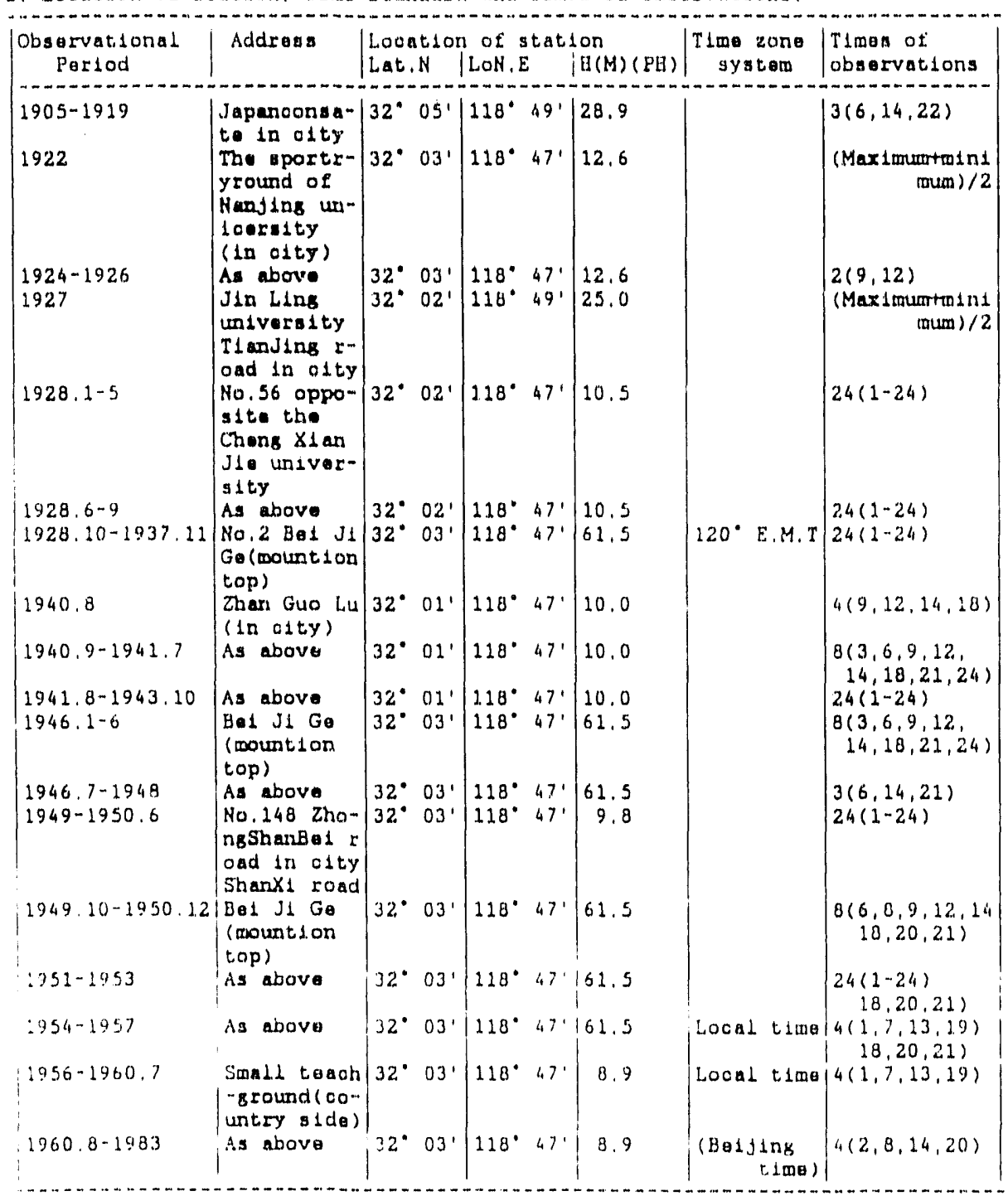


10. 4458238 Ilan Jink (cont.)

C. Humber of Observationa Used for Caloulating the Dafly Moan

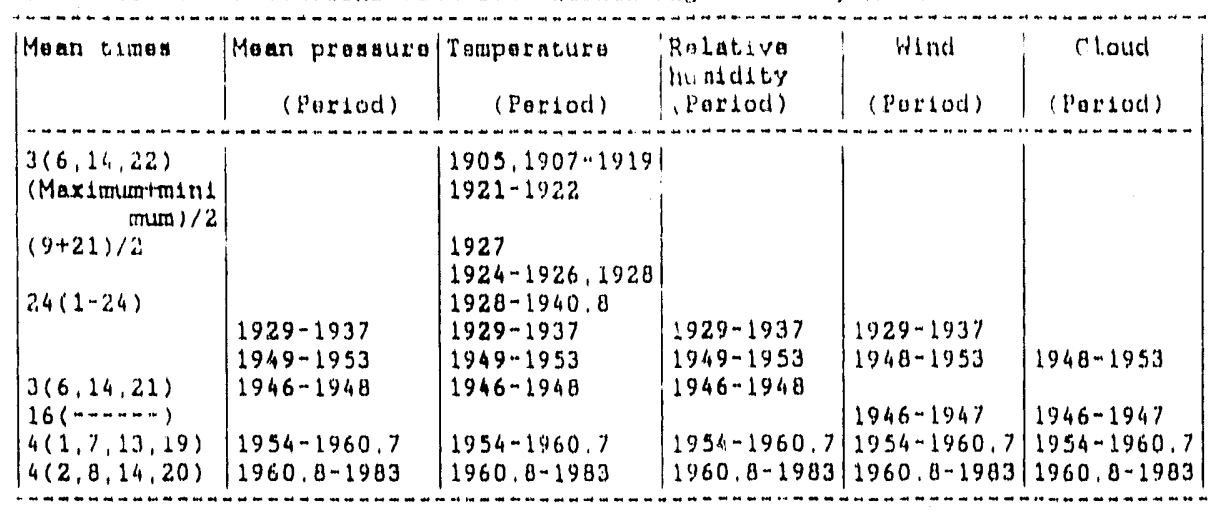

D. Remarka 
A. Masn Data Sourona

$$
\begin{array}{ll}
\text { 1. } & 1873-1990 \\
1073-1910 \\
\text { 2. } & 1951-1980 \\
3 . & 1933-1936,11
\end{array}
$$

$(116)(117)$

\begin{tabular}{|c|c|c|c|c|c|c|}
\hline $\begin{array}{c}\text { Warervational } \\
\text { Pariod }\end{array}$ & Addrass & $\mid \begin{array}{l}\text { l.ouatidot } \\
\text { Lat.N }\end{array}$ & $\left\{\begin{array}{l}\text { of } a t a t i \\
\mid \text { loN }\end{array}\right.$ & $\mid H(M)(P E)$ & \begin{tabular}{|} 
Tham zono \\
gystom
\end{tabular} & $\begin{array}{l}\text { Tlenos of } \\
\text { observatidons }\end{array}$ \\
\hline $\begin{array}{l}1673-1900 \\
1901-1955 \\
1956-1983\end{array}$ & 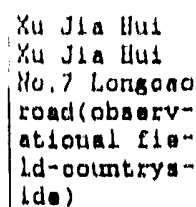 & $\mid \begin{array}{ll}32^{\circ} & 122^{\prime} \\
31^{\circ} & 120^{\prime} \\
& 10^{\prime}\end{array}$ & $\left|\begin{array}{ll}121^{\circ} & 26^{\prime} \\
121^{\circ} & 26^{\prime} \\
121^{\circ} & 26^{\prime}\end{array}\right|$ & $\begin{array}{l}7.0 \\
4.6 \\
4.5\end{array}$ & $\begin{array}{ll}120^{\circ} & E, M, T \\
120^{\circ} & E, M, T \\
120^{\circ} & E, M, T\end{array}$ & $\begin{array}{l}24(1-24) \\
24(1-24) \\
24(1-24)\end{array}$ \\
\hline
\end{tabular}

(110)

(15)

\begin{tabular}{|c|c|c|c|c|c|}
\hline Moan titmea & $\begin{array}{c}\text { Moan pronasura } \\
\text { (Porlod) }\end{array}$ & $\begin{array}{c}\text { Temperaturo } \\
\text { (Porlod) }\end{array}$ & $\begin{array}{l}\text { Relativa } \\
\text { himidity } \\
\text { (Parlod) }\end{array}$ & $\begin{array}{l}\text { Wind } \\
\text { (Poriod) }\end{array}$ & $\begin{array}{l}\text { Cloud } \\
(801 \cdot 100(1)\end{array}$ \\
\hline 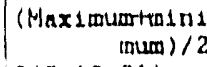 & & $1873 \times 1874$ & & & \\
\hline $\begin{array}{l}3(7,12,21) \\
(14,7,20,13) \\
\quad 16,19,22)\end{array}$ & $\begin{array}{r}1873.1-1074.8 \\
1874.9-1075.1\end{array}$ & & $\begin{array}{l}18 \% 3-1874,8 \\
1874,9-1875,1 \\
1802,12-1883 . \\
1804,1-2\end{array}$ & $\begin{array}{l}1073.1-1874.8 \\
1 \quad 2874.9-1875.1 \\
11\end{array}$ & $\begin{array}{l}1873,1-1874,8 \\
1874,9-18 / 5,1\end{array}$ \\
\hline $\begin{array}{l}B(1,4,7,10 \\
13,26,19,22)\end{array}$ & $1875.2 \cdot 1878.12$ & $|1077,5-1807|$ & $1875.2+1878.2$ & $12 \mid 1875.2-1878.12$ & $|1075.2-1878.12|$ \\
\hline $\begin{array}{l}: 4(1-24) \\
4(1,7,13,19) \\
4(2,8,14,20)\end{array}$ & $\left\{\begin{array}{l}1879,1-1950 \\
1954-1960,1 \\
1951-1953 \\
1960,8-1983\end{array}\right.$ & $\begin{array}{l}1879.1 \cdot 1950 \mid \\
1954-1960.7 \\
1951-1953 \\
1960.8-1983\end{array}$ & $\begin{array}{l}1884.3-1950 \\
1954-1960.7 \\
1951-1953 \\
1960.8-1983\end{array}$ & $\begin{array}{l}18 \% 1-1950 \\
1954-1960.7 \\
1951-1953 \\
1960.8-1983\end{array}$ & $\begin{array}{l}1879.1-1950 \\
1954-1960.7 \\
1951-1953 \\
1960.8-1983\end{array}$ \\
\hline
\end{tabular}

3. Loontion of Station, Tho Standard and Thes of Obarvationa,

C. Number of Obsorvationa Uaud Cor Caloulating tha Dally Moan

D. Remarka:

1. Datie devidad time $24120^{\circ} \mathrm{E}$ man tama betoro 1951 $20120^{\circ} \mathrm{E}$ inean thate attor 1951 
No. $46 \quad 58424$ An Q1ng

A. Maln Data Sourcas

1. $1931 \% 1942$

2. $1990.4-1900$

3. $1901-1983$

$(2)(j)(1 s)$

(119)

(13)

B. Looation of Station, I'Ime Standard and TImes of Observations.

\begin{tabular}{|c|c|c|c|c|c|c|}
\hline $\begin{array}{l}\text { Ohadervational } \\
\text { Poriod }\end{array}$ & Addreas & $\begin{array}{l}\text { Loonatio } \\
\text { Lat..N }\end{array}$ & 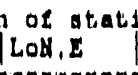 & $\operatorname{lov}_{(M)}(\mathrm{M})(\mathrm{B})$ & $\begin{array}{c}\text { TIme zono } \\
\text { nyation }\end{array}$ & $\begin{array}{l}\text { Thenes of } \\
\text { observations }\end{array}$ \\
\hline $\begin{array}{l}1931-1938 \\
1990.4-1993\end{array}$ & $\begin{array}{l}\text { No.3 elinunoo } \\
\text { otraet (1n } \\
\text { odty) }\end{array}$ & $\mid \begin{array}{ll}30^{\circ} & 37^{\prime} \\
30^{\circ} & 37^{\prime}\end{array}$ & $\left|\begin{array}{ll}117^{\circ} & 041 \\
117^{\circ} & 021^{\prime}\end{array}\right|$ & $\begin{array}{c}-1 . \\
26.3 \\
(32.0)\end{array}$ & $\underset{\text { tidos })}{(B 01 j \sin }$ & $24(1-24)$ \\
\hline $1934-1936$ & $\begin{array}{l}\text { In gaxdon of } \\
\text { militiary ou- } \\
\text { buxea ( In } \\
\text { (1ty) }\end{array}$ & $30^{\circ} 32^{\prime}$ & $1127^{\circ} 02^{\prime}$ & $\begin{array}{c}38,4 \\
(39,5)\end{array}$ & $\begin{array}{l}\text { Looul moan } \\
\text { solur tidmo }\end{array}$ & $4(1,7,13,19)$ \\
\hline $1957-1959.11$ & $\begin{array}{l}\text { Gale and two } \\
\text { li Norih } \\
\text { gate out } \\
\text { counticysido }\end{array}$ & $30^{\circ} 31^{\prime}$ & $117^{\circ} 02^{\prime}$ & $\begin{array}{c}40,9 \\
(42,7)\end{array}$ & $\begin{array}{l}\text { Logal moan } \\
\text { aglar titao }\end{array}$ & $4(1,7,13,19)$ \\
\hline 1959.12 & An abova & $30^{\circ} 31^{\prime}$ & $117^{\circ} 02^{\prime}$ & $\begin{array}{c}42,2 \\
(40,7)\end{array}$ & $\begin{array}{l}\text { Looad mean } \\
\text { solar time }\end{array} \mid$ & $n(1,7,13,19)$ \\
\hline $1960-1961.1$ & As abovo & $30^{\circ} 311$ & $117^{\circ} 02^{\prime}$ & {$\left[\begin{array}{c}42,2 \\
(40,7)\end{array}\right.$} & 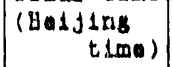 & $4(2,8,10,20)$ \\
\hline $1961,2-1964.9$ & As above & $30^{\circ} 31^{\prime}$ & $117^{\circ} 02^{\prime}$ & $\begin{array}{r}42,2 \\
(43,6)\end{array}$ & 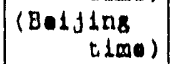 & $4(2,8,28,20)$ \\
\hline $1964.10-19 \%, .12$ & As abovin & $30^{\circ} 31^{\prime}$ & $117^{\circ} 02^{\prime}$ & $\begin{array}{l}44,0 \\
(45,4)\end{array}$ & 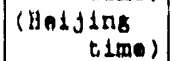 & $4(2,8,18,20)$ \\
\hline $1977.1-1983$ & $\begin{array}{l}\text { Wans Jia Zhd } \\
\text { hound DaQins } \\
\text { roud (Horth } \\
\text { suburb) }\end{array}$ & $30^{\circ} 32^{\prime}$ & $117^{\circ} 03^{\prime}$ & $\begin{array}{c}19,8 \\
(19,6)\end{array}$ & 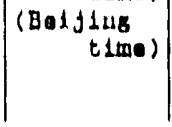 & $4(2,8,18,20)$ \\
\hline
\end{tabular}

C. Numbar of Obaervationu Used for Caloulating tha Dally Mean

\begin{tabular}{|c|c|c|c|c|}
\hline Moan elrous & $\begin{array}{c}\text { Moan proasur } \\
\text { (Dorlod) }\end{array}$ & $\begin{array}{r}\text { Tamperature } \\
(\text { Portod) }\end{array}$ & $\mid \begin{array}{l}\text { Rolative } \\
\text { humidity } \\
\text { (Forlod) }\end{array}$ & $\begin{array}{l}\text { Wlind } \\
\text { (Porlod) }\end{array}$ \\
\hline $\begin{array}{l}24(1,24) \\
1(1,7,13,19) \\
4(2,8,24,20)\end{array}$ & $\mid \begin{array}{l}1950,4 \cdot 19.53 \\
1994-1959 \\
1960-1903\end{array}$ & $\begin{array}{l}1950.4-1993 \\
1954 \cdot 1999 \\
1960-1903\end{array}$ & $\begin{array}{l}1950,4-1953 \\
1954-1959 \\
1960-1983\end{array}$ & $\begin{array}{l}1930,4-1953 \\
1934-1999 \\
1960-1983\end{array}$ \\
\hline
\end{tabular}

Remarks :

! Tho variation of holght $1 \mathrm{~h} .764 .10$ was dus to tha variation of atarting point of tho hasht above sea loval (erom the Song mouth-Huang Hal).

$\therefore$ Tho differonoo of prosaura holght for 1961,2-1964.9 and 1964.10-19\%6. 12 porioda had boon oorraoted.

3.010 narpe: "Huat Ming". 


\section{B..54}

No, 4\% 38457 Hang 2 hou

A. Main Data Souroas

$\begin{array}{ll}\text { 1. } 1904-1950 & (120) \\ \text { 2. } 1951-1970 & (121) \\ \text { 3. } 1971-1980 & (122) \\ \text { 4. } 1981-1983 & (13)\end{array}$

B. Looution of Stiation, TLine Staridard and Tlma of Obsorvetions,

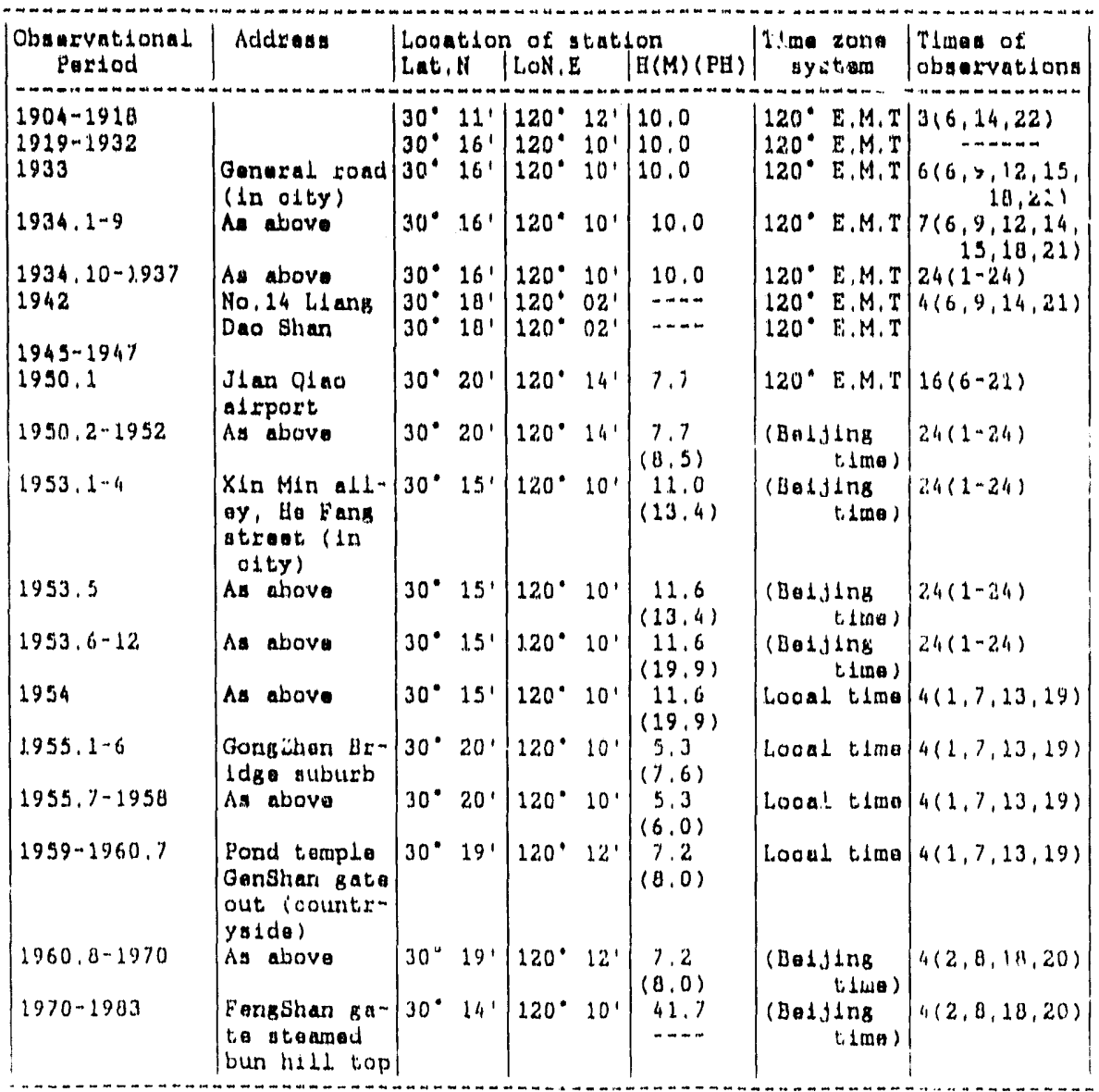

C. Nunber of Obarrvationa Used for Calculating tho Dally Moan

\begin{tabular}{|c|c|c|c|c|}
\hline Mean times & $\begin{array}{c}\text { Moan prousura } \\
\text { (Poriod) }\end{array}$ & $\begin{array}{r}\text { Temperatura } \\
(\text { Partod) }\end{array}$ & $\begin{array}{l}\text { Rolatilve } \\
\text { humidity } \\
\text { (Porlod) }\end{array}$ & $\begin{array}{l}\text { Wind } \\
\text { (Pariod) }\end{array}$ \\
\hline $\begin{array}{l}3(6,14,22) \\
3(6,14,21) \\
24(1-24) \\
4(1,7,13,19) \\
4(2,0,14,20)\end{array}$ & $\mid \begin{array}{l}1933 \\
1904-1918 \\
1034-1937.1950 \\
1954.2-1953 \\
1954-1960.7 \\
1960.8-1983\end{array}$ & $\mid \begin{array}{l}1919-1933,1942 \\
1945-1947 \\
1904-1918 \\
1934-1937,19501 \\
1950.2-1953 \\
1954-1960.7 \\
1960.8-1983\end{array}$ & \begin{tabular}{|l|}
1933,1942 \\
$1945-1947$ \\
$1904-1918$ \\
$1934-1937,1950$ \\
$1950.2-1953$ \\
$1954-1960.7$ \\
$1960.8-1983$
\end{tabular} \mid & $\mid \begin{array}{l}1951-1953 \\
1954-1960.7 \\
1960.8-1983\end{array}$ \\
\hline
\end{tabular}

1). Remarks: 


\section{B-55}

No. 4858606 Nan Chang

A. Main Data Sources
1. $1929-1950$
2. 1951-1962
3. $1963-1970$
4. $1951-1980$
5. $1971-1980$
(123)
(124)
$(6)(7)(8)(9)(10)(11)$
6. $1981-1983$
(159)
(13)

B. Location of Station, Ilow Standard and Ilmes of Observations.

\begin{tabular}{|c|c|c|c|c|c|c|}
\hline $\begin{array}{l}\text { Observational } \\
\text { Portod }\end{array}$ & Address & $\left|\begin{array}{l}\text { Location } \\
\text { Lat.N }\end{array}\right|$ & $\mid$ of stat & $|\mathrm{B}(\mathrm{M})(\mathrm{PE})|$ & $\begin{array}{c}\text { Time zone } \\
\text { system }\end{array}$ & $\begin{array}{l}\text { Times of } \\
\text { observations }\end{array}$ \\
\hline $\begin{array}{l}1929-1935 \\
1936\end{array}$ & Yuzhans park & $\left|\begin{array}{ll}23^{\circ} & 42^{\prime} \\
28^{\circ} & 41^{\prime}\end{array}\right|$ & $\left|\begin{array}{ll}115^{*} & 51^{\prime} \\
115^{\circ} & 54^{\prime}\end{array}\right|$ & & Local time & $\mid \begin{array}{l}3(9,12,15) \\
2(\text { Maximumtmi } 1 \\
\text { n1mum })\end{array}$ \\
\hline $\begin{array}{l}1937 \\
\ln 38.2-6\end{array}$ & $\begin{array}{l}\text { An above } \\
\text { As above }\end{array}$ & $\left|\begin{array}{ll}28^{\circ} & 41^{\prime} \\
28^{\circ} & 41^{\prime}\end{array}\right|$ & $\begin{array}{ll}115^{\circ} & 54^{\prime} \\
115^{\circ} & 54^{\prime}\end{array}$ & & $\begin{array}{l}\text { local tima } \\
120^{\circ} \text { E.M.T }\end{array}$ & $\begin{array}{l}8(3,6,9,12, \\
14,18,21,24)\end{array}$ \\
\hline $\begin{array}{l}1938.7 \\
1938.8-9\end{array}$ & $\begin{array}{l}\text { As above } \\
\text { As above }\end{array}$ & $\left|\begin{array}{ll}28^{\circ} & 41^{\prime} \\
28^{\circ} & 41^{\prime}\end{array}\right|$ & $\begin{array}{ll}115^{\circ} & 54^{\prime} \\
115^{\circ} & 54^{\prime}\end{array}$ & & $\begin{array}{l}120^{\circ} \text { E.M.T } \\
120^{\circ} \text { E.M.T }\end{array}$ & $\begin{array}{c}3(6,14,21) \\
6(6,9,12,14, \\
18,21)\end{array}$ \\
\hline $\begin{array}{l}1246-1948.6 \\
1148.10-1949.2\end{array}$ & $\begin{array}{l}\text { Jin Wal Mon- } \\
\text { umental }\end{array}$ & $\left|\begin{array}{cc}28^{\circ} & 34^{\prime}\end{array}\right|$ & n & 26.0 & $\cdots$ & $16(5-21)$ \\
\hline $1950.6-1952$ & $\begin{array}{l}\text { San J1a D1an } \\
\text { (suburb) }\end{array}$ & $28^{\circ} 40^{\circ}$ & $115^{\circ} 58^{\circ}$ & 26.4 & $\cdots$ & $24(1-24)$ \\
\hline $\begin{array}{l}1953 \\
1954-1960.6\end{array}$ & $\begin{array}{l}\text { As above } \\
\text { Dons ports }\end{array}$ & $\left|\begin{array}{ll}28^{\circ} & 40^{\circ} \\
28^{\circ} & 40^{\circ}\end{array}\right|$ & 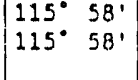 & $\begin{array}{l}27.8 \\
46.7\end{array}$ & $\begin{array}{l}\text { Local mean } \\
\text { solar timo }\end{array}$ & $\begin{array}{l}2.4(1-24) \\
4(1,7,13,19)\end{array}$ \\
\hline $1960.7-1977$ & As above & $28^{\circ} 40^{\prime}$ & $115^{\circ} 58^{\prime}$ & 46.7 & $\left(\begin{array}{c}\text { (Bo1jing } \\
t \text { Imo })\end{array}\right.$ & $4(2,8,18,20)$ \\
\hline $1978-1983$ & As above & $28^{\circ} 36^{\prime}$ & $115^{\circ} 55^{\prime}$ & 46.7 & $\left(B \in 1, \operatorname{lng}_{t \operatorname{lno}}\right)$ & $4(2,8,28,20)$ \\
\hline
\end{tabular}

C. Number of Observations Used for Calculating the Dally Mean

\begin{tabular}{|c|c|c|c|c|}
\hline Moan times & $\begin{array}{c}\text { Mean prassura } \\
\text { (Parlod) }\end{array}$ & $\begin{array}{r}\text { Temperaturo } \\
\text { (Perlod) }\end{array}$ & $\begin{array}{l}\text { Relative } \\
\text { humidity } \\
\text { (Porlod) }\end{array}$ & $\begin{array}{l}\text { Wind } \\
\text { (Poriod) }\end{array}$ \\
\hline 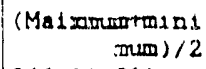 & & 1936 & & \\
\hline $3(6,14,21)$ & & $\begin{array}{l}1937-1938.9 \\
1948.10-1949.2 \\
1929-1935\end{array}$ & $\begin{array}{l}1936.7-1938.9 \\
1948.10-1949.2\end{array}$ & \\
\hline $\begin{array}{l}3(9,12,25) \\
24(1-24) \\
4(1,7,23,19) \\
4(2,8,14,20)\end{array}$ & $\begin{array}{l}1950.6-1953 \\
1954-1960.6 \\
1960.7-1983\end{array}$ & $\begin{array}{l}1950.6-1953 \\
1954-1960.6 \\
1960.7-1983\end{array}$ & $\begin{array}{l}1950.1-1953 \\
1954-1960.6 \\
1960.7-1983\end{array}$ & $\begin{array}{l}1951-1953 \\
1954-1960.6 \\
1960.7-1983\end{array}$ \\
\hline
\end{tabular}

D. Remarks: 


\section{B-56}

No. $49 \quad 58633$ Qu Zhou

A. Main Data Sourcos

$\begin{array}{ll}\text { 1. } 1951-1970 & (127) \\ \text { 2. } 1971-1980 & (128)(159) \\ \text { 3. } 1981-1983 & (13)\end{array}$

B. Location of Station, Time Standard and Times of Obsarvations.

\begin{tabular}{|c|c|c|c|c|c|c|}
\hline $\begin{array}{l}\text { Observational } \\
\text { Porlod }\end{array}$ & Address & $\mid \begin{array}{l}\text { Location } \\
\text { Lat.N }\end{array}$ & $\begin{array}{l}\text { nof stat } \\
\text { LoN.E }\end{array}$ & ion & $\begin{array}{c}\text { Time zono } \\
\text { systom }\end{array}$ & $\begin{array}{l}\text { Tlmes of } \\
\text { observations }\end{array}$ \\
\hline $1951.1-2$ & Qu Zhou & $\left|28^{\circ} 58^{\prime}\right|$ & $118^{\circ} 53^{\prime}$ & $\mid \begin{array}{c}68.6 \\
(72.8)\end{array}$ & $\begin{array}{c}(B \cdot 1 j \operatorname{lng} \\
t \text { Ime })\end{array}$ & $24(1-24)$ \\
\hline $1951.2-1952.1$ & $\begin{array}{l}\text { Qu thou Fu } \\
\text { b111. }\end{array}$ & $28^{\circ} 58^{\prime}$ & $118^{\circ} 53^{\circ}$ & $\begin{array}{c}80.3 \\
(80.8)\end{array}$ & $\begin{array}{c}(B \theta 1 J 1 n g \\
\operatorname{tine})\end{array}$ & $24(1-24)$ \\
\hline $1952.2-1953$ & As above & $28^{\circ} 58^{\prime}$ & $116^{\circ} 53^{\prime}$ & $\begin{array}{l}80.0 \\
(80.8)\end{array}$ & $\begin{array}{c}(B \bullet 1 J \operatorname{lng} \\
t \perp \log )\end{array}$ & $24(1-24)$ \\
\hline 1954 & $\begin{array}{l}\text { East oity } \\
\text { (suburb) }\end{array}$ & $28^{\circ} 58^{\prime}$ & $118^{\circ} 53^{\prime}$ & $\left(\begin{array}{l}80.0 \\
(-\cdots)\end{array}\right.$ & Local time & $4(1,7,13,19)$ \\
\hline $1955.1-9$ & As bove & $28^{\circ} 58^{\prime}$ & $118^{\circ} 53^{\prime}$ & $\begin{array}{l}62.0 \\
(63.0)\end{array}$ & Local time & $4(1,7,13,19)$ \\
\hline $1955.10-1960.7$ & $\begin{array}{l}\text { Northern ga- } \\
\text { to out } \\
\text { (suburb) }\end{array}$ & $28^{\circ} 58^{\prime}$ & $118^{\circ} 52^{\prime}$ & $(66.1)$ & Local timo & $4(1,7,13,19)$ \\
\hline $1960.8-1974.2$ & As above & $28^{\circ} 58^{\circ}$ & $118^{\circ} 52^{\prime}$ & $\begin{array}{c}66.1 \\
(67.1)\end{array}$ & $\begin{array}{c}(B+1 j \operatorname{lng} \\
\text { time })\end{array}$ & $4(2,8,18,20)$ \\
\hline $1974.3-1975.5$ & As above & $28^{\circ} 58^{\prime}$ & $118^{\circ} 52^{\prime}$ & $\begin{array}{c}66.1 \\
(71.0)\end{array}$ & $\begin{array}{c}(B \circ j \operatorname{lng} \\
\text { tims) }\end{array}$ & $4(2,8,18,20)$ \\
\hline $1975.7-1976$ & As above & $28^{\circ} 58^{\prime}$ & $118^{\circ} 52^{\prime}$ & {$\left[\begin{array}{c}66.7 \\
(71.0)\end{array}\right.$} & $\begin{array}{c}\text { (Boljing } \\
\text { time) }\end{array}$ & $4(2,8,18,20)$ \\
\hline$: 977-1983$ & As above & $28^{\circ} 58^{\prime}$ & $118^{\circ} 52^{\prime}$ & $\begin{array}{c}66.9 \\
(71.0)\end{array}$ & $\begin{array}{c}(B \otimes 1 j \text { ing } \\
\text { time })\end{array}$ & $4(2,8,16,20)$ \\
\hline
\end{tabular}

C. Number of Obsurvations Used for Calculating the Dadly Moen

\begin{tabular}{|c|c|c|c|c|}
\hline Moan times & $\begin{array}{c}\text { Moan prossure } \\
\text { (Poriod) }\end{array}$ & $\begin{array}{r}\text { Temporatiuro } \\
\text { (Pariod) }\end{array}$ & $\begin{array}{l}\text { Rolative } \\
\text { humidity } \\
\text { (Pordod) }\end{array}$ & $\begin{array}{l}\text { Wind } \\
\text { (Poriod) }\end{array}$ \\
\hline $\begin{array}{l}24(1-24) \\
8(3,6,9,12, \\
15,18,21,24)\end{array}$ & $1955.1-1955.9$ & $\begin{array}{l}1951-1953 \\
1951-1955.9\end{array}$ & $\begin{array}{l}1931-1953 \\
1934-1955.9\end{array}$ & $\begin{array}{l}1951-1953 \\
1954-1955.9\end{array}$ \\
\hline $\begin{array}{l}4(1,7,13,19) \\
4(2,8,14,20)\end{array}$ & \begin{tabular}{|l}
$1955.10-1960.7$ \\
$1960.8-1983$
\end{tabular} & $\mid \begin{array}{l}19.50 .10-1960.7 \\
1960.8-1983\end{array}$ & $\begin{array}{l}5.10-1960.7 \\
0.8-1983\end{array}$ & $\begin{array}{l}1955.10-1960 \\
1960.8-1983\end{array}$ \\
\hline
\end{tabular}

ว. Remarixs: 
No. $50 \quad 58659$ Wen zhou

A. Main Data Saurces
1. $1883-1950$
2. $1951-1970$
3. $1971-1980$
4. $1981-1983$
(129)
(130)
(159)(131)
5. $1951-1954$
(13)

B. Location of Station, I1me Standard and Times of Observations.

\begin{tabular}{|c|c|c|c|c|c|c|c|}
\hline $\begin{array}{l}\text { Obaervational } \\
\text { Period }\end{array}$ & Addreass & $\begin{array}{l}\text { Locatior } \\
\text { Lat.N }\end{array}$ & $\begin{array}{l}\text { Oof } \\
\text { |LON.E }\end{array}$ & $E^{s t a t}$ & ion & $\begin{array}{c}\text { T1me zone } \\
\text { syatem }\end{array}$ & $\begin{array}{l}\text { Times of } \\
\text { observations }\end{array}$ \\
\hline $\begin{array}{l}1883-1923 \\
1924-1925.10\end{array}$ & $\begin{array}{l}\text { Motworologi- } \\
\text { cal station } \\
\text { of custuos }\end{array}$ & $\left|\begin{array}{ll}28^{\circ} & 01^{\prime} \\
28^{\circ} & 01^{\prime}\end{array}\right|$ & $\begin{array}{l}120^{\circ} \\
120^{\circ}\end{array}$ & $\begin{array}{l}388^{\prime} \\
38^{\prime}\end{array}$ & $\begin{array}{l}4.3 \\
4.3\end{array}$ & $\left|\begin{array}{c}120^{\circ} \text { E.M.I. } \\
\text { n.... }\end{array}\right|$ & $2(9,15)$ \\
\hline $\begin{array}{l}1925.11-1927.7 \\
1929.9 \\
1927.8-1929.8\end{array}$ & $\begin{array}{l}\text { As above } \\
\text { As above }\end{array}$ & $\begin{array}{l}28^{\circ} 01^{\prime} \\
28^{\circ} 01^{\prime}\end{array}$ & $\begin{array}{l}120^{\circ} \\
120^{\circ}\end{array}$ & $\begin{array}{l}38^{\prime} \\
38^{\prime}\end{array}$ & $\begin{array}{l}4.3 \\
4.3\end{array}$ & $\begin{array}{l}120^{\circ} \text { E.M.T } \\
120^{\circ} \text { E.M.I } \\
120^{\circ} \text { E.M.T }\end{array}$ & $\begin{array}{l}3(9,12,15) \\
3(9,12,14)\end{array}$ \\
\hline $\begin{array}{l}1929.11-1932.12 \\
1929.10\end{array}$ & As above & $28^{\circ} 01^{\prime}$ & $120^{\circ}$ & $38^{\prime}$ & 4.3 & $120^{\circ}$ E.M.T & $\begin{array}{r}4(9,12,14 \\
16)\end{array}$ \\
\hline $\begin{array}{l}1933 \\
1934-1938.10 \\
1938.11-1941\end{array}$ & $\begin{array}{l}\text { As abova } \\
\text { As above }\end{array}$ & $\begin{array}{ll}28^{\circ} & 01^{\prime} \\
28^{\circ} & 01^{\prime}\end{array}$ & $\begin{array}{l}120^{\circ} \\
120^{\circ}\end{array}$ & $\begin{array}{l}38^{\prime} \\
38^{\prime}\end{array}$ & $\begin{array}{l}4.3 \\
4.3\end{array}$ & $\left|\begin{array}{ll}120^{\circ} & \text { E.M.T.T } \\
120^{\circ} & \text { E.M.I } \\
120^{\circ} & \text { E.M.I. }\end{array}\right|$ & $\begin{array}{c}8(3,6,9,12, \\
3(6,14,21)\end{array}$ \\
\hline 1950.1 & $\begin{array}{l}\text { No. } 13 \text { kan Er } \\
\text { alloy }\end{array}$ & $28^{\circ} 01^{\prime}$ & $120^{\circ}$ & $40^{\prime}$ & 4.0 & $120^{\circ}$ E.M.T & $\begin{array}{l}8(3,6,9,12, \\
15,18,21,24)\end{array}$ \\
\hline $\begin{array}{l}1950.2-3 \\
1950.4-12 \\
1951-1952.9\end{array}$ & $\begin{array}{l}\text { As abovo } \\
\text { As above } \\
\text { J1 ao } X 1 \text { ang a } \\
\text { Lley in c1ty }\end{array}$ & 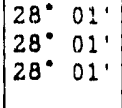 & $\begin{array}{l}120^{\circ} \\
120^{\circ} \\
120^{\circ}\end{array}$ & $\begin{array}{l}40^{\circ} \\
40^{\circ} \\
40^{\circ}\end{array}$ & $\begin{array}{l}4.0 \\
7.9 \\
7.9\end{array}$ & $\mid \begin{array}{ll}120^{\circ} & \text { E.M.M.T } \\
120^{\circ} \text { E.M.T } \\
(B, 1, \text { Ing }\end{array}$ & $\begin{array}{l}16(-1-2) \\
24(1-24) \\
24(1-24)\end{array}$ \\
\hline $1952.10-1953.1$ & $\begin{array}{l}\text { YongDong ro- } \\
\text { ad KanEID1 } \\
\text { as gate out }\end{array}$ & $28^{\circ} 02^{\prime}$ & $120^{\circ}$ & $40^{\prime}$ & 4.0 & $\mid \begin{array}{r}(8 \bullet 1 j \operatorname{lng} \\
\operatorname{tin} \bullet)\end{array}$ & $2.4(1-24)$ \\
\hline $\begin{array}{l}1954-1960.6 \\
1960.7\end{array}$ & $\begin{array}{l}\text { As above } \\
\text { NanTang town } \\
\text { Shuang Jing } \\
\text { Tou (countr- } \\
\text { yside) }\end{array}$ & $\mid \begin{array}{ll}28^{\circ} & 01^{\prime} \\
28^{\circ} & 01^{\prime}\end{array}$ & $\begin{array}{l}120^{\circ} \\
120^{\circ}\end{array}$ & $\begin{array}{l}40^{\prime} \\
40^{\prime}\end{array}$ & $\begin{array}{r}10.0 \\
7.0\end{array}$ & $\left|\begin{array}{ll}\text { Local time } \\
\text { Looal titeo }\end{array}\right|$ & $\begin{array}{l}4(1,7,13,19 \\
4(1,7,13,19)\end{array}$ \\
\hline 1960.8 & As above & $28^{\circ} 01^{\prime}$ & $120^{\circ}$ & $40^{\circ}$ & 7.0 & $\left(\begin{array}{c}(B) \perp j \operatorname{lng} \\
\operatorname{tin} \theta)\end{array}\right.$ & $4(2,8,18,20)$ \\
\hline 1960.9 & As above & $28^{\circ} 01^{\prime}$ & $120^{\circ}$ & 401 & 10.0 & $\left|\begin{array}{c}(B+1 j \operatorname{lng} \\
\text { tIme })\end{array}\right|$ & $4(2,8,18,20)$ \\
\hline $1960.10-1978$ & As above & $28^{\circ} 01^{\prime}$ & $120^{\circ}$ & $40^{\prime}$ & 6.9 & $\left|\begin{array}{c}(8.1) \operatorname{lng} \\
\operatorname{tim} \theta\end{array}\right|$ & $4(2,8,18,20)$ \\
\hline $1979-1983$ & As above & $28^{\circ} 01^{\prime}$ & $120^{\circ}$ & $40^{\prime}$ & 7.1 & $\mid \begin{array}{c}(B \operatorname{dolng} \\
\operatorname{time}) \mid\end{array}$ & $\mid 4(2,8,18,20)$ \\
\hline
\end{tabular}




\section{B-58}

No. 5058659 Wen thou (cont.)

C. Number of Obsarvations Usad for Calculating the Dally Mean

\begin{tabular}{|c|c|c|c|c|c|}
\hline Mean times & $\left\{\begin{array}{c}\text { Mean pressure } \\
\text { (Poriod) }\end{array}\right.$ & $\mid \begin{array}{r}\text { Temperature } \\
(\text { Period) }\end{array}$ & $\begin{array}{l}\text { Relative } \\
\text { humidity } \\
\text { (Poriod) }\end{array}$ & $\begin{array}{l}\text { Wind } \\
\text { (Portod) }\end{array}$ & $\begin{array}{l}\text { Cloud } \\
\text { (Period) }\end{array}$ \\
\hline $\begin{array}{r}(\text { Maximumtmind } \\
\text { mum }) / 2\end{array}$ & & $1924-1932$ & & & \\
\hline $\begin{array}{c}3(6,14,21) \\
6(6,9,12,14 \\
18,21, \\
8(3,6,9,12 \\
15,18,21,24)\end{array}$ & $1934-1938$ & $1934-1938$ & $\left\{\begin{array}{l}1934-1938 \\
1933\end{array}\right.$ & $1934-1938$ & $1934-1938$ \\
\hline $\begin{array}{l}8(3,6,9,12, \\
\quad 15,18,21,24)\end{array}$ & 1950.1 & 1950.1 & 1950.1 & & \\
\hline $\begin{array}{l}16(6-21) \\
24(1-24)\end{array}$ & $1950.2-1933$ & $\begin{array}{l}1950.2-1.953 \\
1938.11-1941\end{array}$ & $1950.2-1953$ & $\begin{array}{l}1950,4-1953 \\
1933\end{array}$ & $\begin{array}{l}1950.2-3 \\
1950.4-1953 \\
1933\end{array}$ \\
\hline $\begin{array}{l}4(1,7,13,29) \\
4(2,8,14,20) \\
3(8,14,20)\end{array}$ & $\begin{array}{l}1954-1960.7 \\
1960.8-1983\end{array}$ & $\begin{array}{l}1954-1960.7 \\
1960.8-1983\end{array}$ & $\begin{array}{l}1954-1960.7 \\
1960.8-1983\end{array}$ & $\begin{array}{l}1954-1960.7 \\
1960.8-1983 \\
1968.9 .10\end{array}$ & nas \\
\hline
\end{tabular}

D. Remarks :

: Old name: "Yong Jia". 
No. 5158847 Fu Zhou

A. Main Data Sources
1. $1880-1944$
(132)
2. $1945-1950$
(133)
3. $1951-1980$
4. $1981-1983$
(134)
5. $1905-1923$
$1946-1947$
6. 1928-1938
(15)

B. Location of Station, Time Standard and Times of Observations.

\begin{tabular}{|c|c|c|c|c|c|c|}
\hline $\begin{array}{l}\text { Observat lonal } \\
\text { Porlod }\end{array}$ & Addroses & $\mid \begin{array}{l}\text { Looation } \\
\text { Lat.N }\end{array}$ & $\begin{array}{l}\text { a of stat. } \\
\text { LON.E }\end{array}$ & $|\mathrm{An}(\mathrm{M})(\mathrm{PQ})|$ & $\begin{array}{c}\text { Tleoe zono } \\
\text { ays texa }\end{array}$ & $\begin{array}{l}\text { TLees of } \\
\text { observations }\end{array}$ \\
\hline $1880-1904$ & $\begin{array}{l}\text { Custuons sta- } \\
\text { t100 }\end{array}$ & -... & $\cdots$ & $\cdots$ & $\cdots+-\infty$ & $\cdots-\cdots$ \\
\hline $\begin{array}{l}1909-1923 \\
1924-1931.3 \\
1931.4-1932.8\end{array}$ & $\begin{array}{l}\text { As above } \\
\text { As above } \\
\text { As above }\end{array}$ & $\begin{array}{ll}26^{\circ} & 00^{\prime} \\
2.5^{\circ} & 59^{\prime} \\
25^{\circ} & 59^{\prime}\end{array}$ & $\begin{array}{l}119^{\circ} 20^{\prime} \\
119^{\circ} 27^{\prime} \\
119^{\circ} 27^{\prime}\end{array}$ & $\begin{array}{l}19.8 \\
19.8\end{array}$ & $\begin{array}{ll}120^{\circ} & \text { E.M.T. } \\
120^{\circ} & \text { E.M. T } \\
120^{\circ} & \text { E.M.T T }\end{array}$ & $\begin{array}{l}2(9,15) \\
4(3,9,15,21) \\
5(3,6,9,15,\end{array}$ \\
\hline $1932.9-1933$ & As above & $25^{\circ} 59^{\prime}$ & $119^{\circ} 27^{\prime}$ & 19.8 & $120^{\circ}$ E.M.T & $\begin{array}{l}8(3,6,9,12 \\
14,18,21,24)\end{array}$ \\
\hline $\begin{array}{l}1934-1935 \\
1936 \\
1938.6-12\end{array}$ & J1. Fan roud & $\begin{array}{ll}25^{\circ} & 59^{\prime} \\
26^{\circ} & 05^{\prime}\end{array}$ & $\begin{array}{l}119^{\circ} 27^{\prime} \\
119^{\circ} 00^{\prime}\end{array}$ & 19.8 & $\begin{array}{ll}120^{\circ} & \text { E.M.T } \\
120^{\circ} & \text { E.M.T }\end{array}$ & $\begin{array}{l}3(6,14,21) \\
8(3,6,9,12, \\
14,18,21,24)\end{array}$ \\
\hline $\begin{array}{l}1937-1938.5 \\
1939-1940.6 \\
1940.7-1944\end{array}$ & $\begin{array}{l}\text { As above } \\
\text { As above } \\
\text { As above }\end{array}$ & $\begin{array}{ll}26^{\circ} & 0.5 \\
26^{\circ} & 05^{\prime} \\
26^{\circ} & 0.5^{\prime}\end{array} \mid$ & 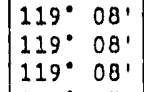 & $\begin{array}{r}10 . \\
19.8 \\
19.8\end{array}$ & $\begin{array}{l}120^{\circ} \text { E.M.I } \\
120^{\circ} \text { E.M.T } \\
120^{\circ} \text { E.M.I }\end{array}$ & $\begin{array}{l}24(1,-24) \\
3(6,14,21)\end{array}$ \\
\hline $1946.1-3$ & $\begin{array}{l}\text { Wans Jia an- } \\
\text { costral tam- } \\
\text { ple wi Sh1 } \\
\text { hil.1. }\end{array}$ & $26^{\circ} 05^{\prime}$ & $119^{\circ} 17^{\prime}$ & 68.9 & $120^{\circ}$ E,M,I & $16(6-21)$ \\
\hline $\begin{array}{l}1946.4-7 \\
1946.8-1948.4 \\
1948.5-1950.6 \\
1950.7-1953 \\
1944.1-1960.7 \\
1960.8-1964.6\end{array}$ & $\begin{array}{l}\text { As above } \\
\text { As above } \\
\text { As above } \\
\text { As above } \\
\text { As above } \\
\text { As above }\end{array}$ & 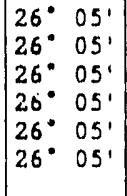 & 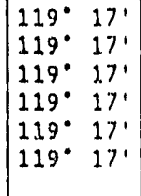 & $\begin{array}{l}68.9 \\
68.9 \\
88.9 \\
88.9 \\
84.0 \\
84.0\end{array}$ & $\begin{array}{l}120^{\circ} \text { E.M.T } \\
120^{\circ} \text { E.M.T } \\
120^{\circ} \text { E.M. I } \\
120^{\circ} \text { E.M.I } \\
\text { Looal t1mo } \\
\text { (Bo1jting } \\
\text { t1mo) }\end{array}$ & $\begin{array}{l}16(6-21) \\
16(6-21) \\
16(6-21) \\
16(6-21) \\
4(1,7,13,19) \\
4(2,8,14,20)\end{array}$ \\
\hline $1964.7-1979.10$ & As above & $26^{\circ} 05^{\prime}$ & $119^{\circ} 17^{\prime}$ & 84.0 & $\begin{array}{c}(B, 1] 1 n g \\
t \in \mathbb{1} \theta)\end{array}$ & $4(2,8,14,20)$ \\
\hline $1979.11-1983$ & As above & $26^{\circ} 05^{\prime}$ & $119^{\circ} 17^{\prime}$ & 83.8 & $\left(\begin{array}{c}(B) 1 j \operatorname{lng} \\
\operatorname{tim} \theta)\end{array}\right.$ & $4(2,8,14,20)$ \\
\hline
\end{tabular}

C. Number of Observations Used for Calculating the Dally Mean

\begin{tabular}{|c|c|c|c|c|c|}
\hline Mean times & $\begin{array}{c}\text { Mean prosaure } \\
\text { (Portod) }\end{array}$ & $\begin{array}{r}\text { Temperaliura } \\
\text { (Pariod) }\end{array}$ & $\begin{array}{l}\text { Relative } \\
\text { humddity } \\
\text { (PoLiod) }\end{array}$ & $\begin{array}{l}\text { Wind } \\
\text { (Poriod) }\end{array}$ & $\begin{array}{l}\text { Cloud } \\
\text { (Pertod) }\end{array}$ \\
\hline 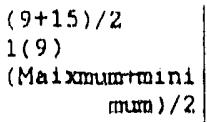 & & $\begin{array}{l}1905-1923 \\
1924-1932.8\end{array}$ & $1924-1932.8$ & & \\
\hline $3(6,14,21)$ & $\begin{array}{l}1935,1938-1941 \\
1946,4-7\end{array}$ & $\begin{array}{l}1934-1935 \\
1941.12 \\
1938.6-1940\end{array}$ & $\begin{array}{l}1934-1935 \\
1938-1941\end{array}$ & & \\
\hline $16(6-21)$ & $\begin{array}{l}1946 \cdot 1-3 \\
1946.8-1950.6\end{array}$ & $\begin{array}{l}1946.1-3 \\
1946,8-1950.6 \\
1946,8-7\end{array}$ & $1946-1947$ & $\begin{array}{l}1946,1-3 \\
1946,8 \cdot 1950,6 \\
1946,4-7\end{array}$ & $\begin{array}{l}1946.1-3 \\
1946.8-1950.6 \\
1946.4-7\end{array}$ \\
\hline $\begin{array}{l}8(3,6,9,12, \\
14,18,21,24) \\
24(1-2.4)\end{array}$ & $\begin{array}{l}1936 \\
1937 \\
1950 \cdot 7-1953\end{array}$ & $\begin{array}{l}1932.9-1933 \\
1936 \\
1937-1938.5 \\
1941.1-3\end{array}$ & $\begin{array}{l}1932.9-1933 \\
1936 \\
1937 \\
1942-1944\end{array}$ & & \\
\hline $\begin{array}{l}4(1,7,13,19) \\
4(2,8,14,20)\end{array}$ & $\begin{array}{l}1954-1960.7 \\
1960.8-1983\end{array}$ & $\begin{array}{l}1950,7-1953 \\
1954-1960.7 \\
1960.8-1983\end{array}$ & $\begin{array}{l}1950.7-1953 \\
1954-1960.7 \\
1960.8-1983\end{array}$ & $\begin{array}{l}1950.7-1953 \\
1954-1960.7 \\
1960.8-1983\end{array}$ & $\begin{array}{l}1950.7-1953 \\
1954-1960.7 \\
1960.8-1983\end{array}$ \\
\hline
\end{tabular}

j. Remarks: 
A. Main Data Sources

$\begin{array}{ll}\text { 1. } 1938-1950 & (135) \\ \text { 2. } 1951-1980 & (136) \\ \text { 3. } 1981-1983 & (13) \\ \text { 4. } 1951-1954 & (12)\end{array}$

B. Location of Station. TIme Standard and Tlmes of Observations,

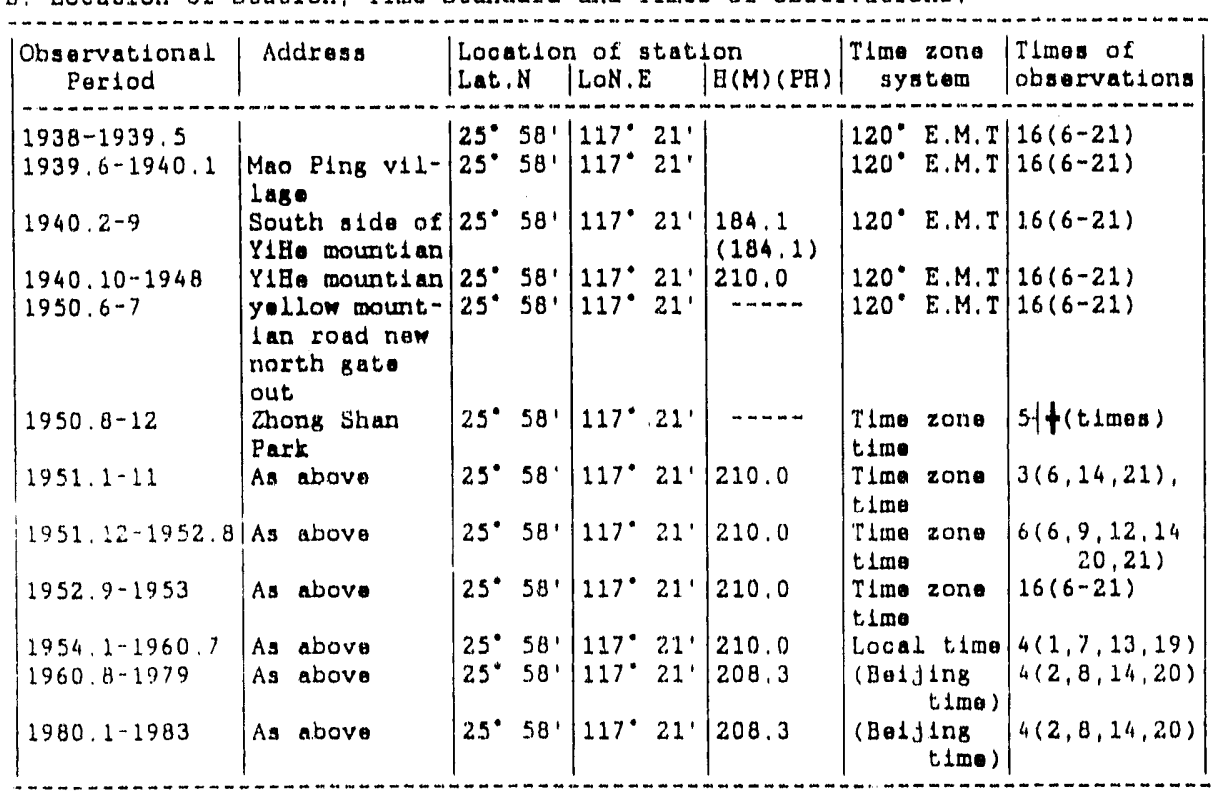

C. Number of Obsorvations Used for Calculating the Dally Mean

\begin{tabular}{|c|c|c|c|c|c|}
\hline Mean times & $\mid \begin{array}{c}\text { Mean prossure } \\
\text { (Perlod) }\end{array}$ & $\mid \begin{array}{r}\text { Temperature } \\
(\text { Perlod })\end{array}$ & $\mid \begin{array}{l}\text { Rolative } \\
\text { humidity } \\
\text { (Poriod) }\end{array}$ & $\begin{array}{l}\text { Wind } \\
\text { (Poriod) }\end{array}$ & $\begin{array}{l}\text { Cloud } \\
\text { (Portod) }\end{array}$ \\
\hline $\begin{array}{l}3(6,14,21) \\
4(1,7,13,19) \\
16(6-21) \\
24(2-24) \\
4(1,7,23,19) \\
4(2,8,14,20)\end{array}$ & $\begin{array}{l}1938.10-1948 \\
1940-1947 \\
1948-1950 \\
1953 \\
1954-1960.7 \\
1960.8-1983\end{array}$ & $\begin{array}{l}1938.10-1948 \\
1954-1960.7 \\
1960.8-1983\end{array}$ & $\begin{array}{l}1954-1960.7 \\
1960.8-1983\end{array}$ & $\left|\begin{array}{|}1954-1960.7 \\
1960.8-1983\end{array}\right|$ & $\begin{array}{l}1938.10-1948 \\
1951-1952 \\
1953\end{array}$ \\
\hline
\end{tabular}

D. Rounarks : 
No, 5359046 L1ou thou Sha Tang

A. Maln Data Sourona

$\begin{array}{lr}\text { 1. } 1936-1957 & (137) \\ \text { 2. } 1959-1960 & (12) \\ \text { 3. } 1961-1970 \text { (moan/max/min toupporature, oloud anount } & \\ \text { 4. } 1961-1980 & \text { and proolpttation) } \\ \text { 5. } 1981-1983 & (137) \\ & (13)\end{array}$

B. Location of Stution, TImo Standard and TImos of Observations.

\begin{tabular}{|c|c|c|c|c|c|c|}
\hline $\begin{array}{l}\text { Observational } \\
\text { Period }\end{array}$ & Addrous & $\begin{array}{l}\text { Loontior } \\
\text { Lat, N }\end{array}$ & $\mid$ of ats. & $\begin{array}{l}100 \\
\mid \mathrm{B}(\mathrm{M})(\mathrm{PH})\end{array}$ & 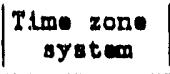 & $\mid \begin{array}{l}\text { Times of } \\
\text { observations }\end{array}$ \\
\hline 1936 & In agrioult - & $24^{\circ} 28^{\prime}$ & $\left|109^{\circ} 22^{\prime}\right|$ & 1207.0 & $105^{\circ}$ E.M.T & $3(6,14,21)$ \\
\hline $1937-1944.9$ & As above & $24^{\circ} 28^{\prime}$ & $109^{\circ} 22^{\prime}$ & 107.0 & $105^{\circ}$ E.M.I & $6(6,9,12,14$, \\
\hline $1946-1947$ & As abovo & $24^{\circ} 28^{\prime}$ & $109^{\circ} 22^{\prime}$ & 107.0 & $105^{\circ}$ E.M.T & $6(6,9,12,14$, \\
\hline $1948-1951$ & As above & $24^{\circ} 28^{\prime}$ & $109^{\circ} 22^{\prime}$ & $\cdots \cdots+$ & $105^{\circ}$ E.M.T & $\begin{array}{r}6(6,9,12,14) \\
18,21)\end{array}$ \\
\hline $1952-1954.6$ & As above & $24^{\circ} 28^{\prime}$ & $109^{\circ} 22^{\prime}$ & 207.0 & $109^{\circ}$ E.M.I & $\begin{array}{r}6(6,9,12,14, \\
(0,21)\end{array}$ \\
\hline $1954.1-1960.7$ & A. above & $24^{\circ} 28^{\prime}$ & $100^{\circ} 22^{\prime}$ & 97.6 & $\begin{array}{l}\text { Loond mean } \\
\text { golur time }\end{array}$ & $(1,7,12,19)$ \\
\hline $1960.8-1983$ & As bove & $24^{\circ} 2 A^{\prime}$ & $109^{\circ} 22^{\prime}$ & 97.6 & $\begin{array}{l}\text { Looul moan } \\
\text { oolax timo }\end{array}$ & $4(2,8,14,20)$ \\
\hline
\end{tabular}

C. Number of Observationa Uand for Caloulatins the Dadly Moan

\begin{tabular}{|c|c|c|c|c|}
\hline Mean timex & $\mid \begin{array}{c}\text { Moen prosure } \\
\text { (Portod) }\end{array}$ & $\begin{array}{r}\text { T'amperatur } \\
\text { (Period) }\end{array}$ & $\mid \begin{array}{l}\text { Relative } \\
\text { bumidity } \\
\text { (Poriod) }\end{array}$ & $\begin{array}{l}\text { Wtad } \\
\text { (Poriod) }\end{array}$ \\
\hline $\begin{array}{r}3(6,14,21) \\
6(6,9,12,14 \\
18,21) \\
8(3,6,9,12 \\
14,18,21,24) \\
4(1,7,23,19) \\
4(2,8,14,20)\end{array}$ & $\begin{array}{l}1936 \\
1937-1944.9 \\
1946-1954.6 \\
1954.7-1960.7 \\
1960.8-1983\end{array}$ & $\mid \begin{array}{l}1936-1944.9 \\
1946-1954.6\end{array}$ & $\begin{array}{l}1936 \\
1937-1944.9 \\
1946-1954.6\end{array}$ & $\begin{array}{l}1936-1944,9 \\
1946-1954,0\end{array}$ \\
\hline
\end{tabular}

D. Remark B : 
A. Main Data Souroea

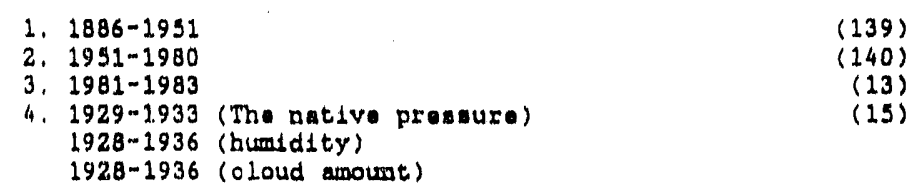

B. Looation of Station, TIme standard and Timon of Obsurvations.

\begin{tabular}{|c|c|c|c|c|c|c|}
\hline $\begin{array}{l}\text { Obsorvational } \\
\text { Porlod }\end{array}$ & Addros: & $\left|\begin{array}{l}\text { Looat 1on } \\
\text { Lat. N }\end{array}\right|$ & $\mid \begin{array}{l}\text { of stat stat } 1 \\
\mid \mathrm{z}\end{array}$ & 100 & $\begin{array}{c}\text { T1on zone } \\
\text { system }\end{array}$ & $\begin{array}{l}\text { Times of } \\
\text { observations }\end{array}$ \\
\hline $\begin{array}{l}1886 \cdots 1923 \\
1924-1933\end{array}$ & moteorolosi- & $\left|\begin{array}{ll}24^{\circ} & 26^{\prime} \\
24^{\circ} & 26^{\prime}\end{array}\right|$ & $\left|\begin{array}{lll}118^{\circ} & 04^{\prime} \\
110^{\circ} & 04^{\prime}\end{array}\right|$ & $\begin{array}{l}4.9 \\
4.9\end{array}$ & $\begin{array}{l}120^{\circ} \text { E.M.T } \\
120^{\circ} \text { E.M.T }\end{array}$ & $\begin{array}{c}8(3,6,9,12, \\
14,18,21,24)\end{array}$ \\
\hline $\begin{array}{l}1934-1938.10 \\
1947-1948.6 \\
1948.7-1949 \\
1950.1-5\end{array}$ & $\begin{array}{l}\text { A above } \\
\text { A above } \\
\text { Al bovo } \\
\text { Gao } 01 \text { aldsp } \\
\text { ort }\end{array}$ & $\begin{array}{l}24^{\circ} 26^{\prime} \\
24^{\circ} \\
24^{\circ} \\
24^{\circ} \\
27^{\circ} \\
3^{\prime}\end{array} \mid$ & $\left|\begin{array}{ll}118^{\circ} & 04^{\prime} \\
110^{\circ} & 02^{\prime} \\
118^{\circ} & 02^{\prime} \\
118^{\circ} & 03^{\prime}\end{array}\right|$ & $\begin{array}{r}4.9 \\
23.4 \\
23.4 \\
12.0\end{array}$ & $\begin{array}{l}120^{\circ} \text { E.M.T } \\
120^{\circ} \text { E.M.T } \\
120^{\circ} \text { E.M.T } \\
1.20^{\circ} \text { E.M.T }\end{array}$ & $\begin{array}{l}3(6,14,21) \\
16(6-21) \\
16(6-21)\end{array}$ \\
\hline $1950.6-10$ & $\begin{array}{l}\text { Na.6 Bat Ho } \\
\text { road }\end{array}$ & $24^{\circ} 25^{\prime}$ & $118^{\circ} 0.2^{\prime}$ & 40.0 & $120^{\circ}$ E,M, T & $24(1-24)$ \\
\hline $\begin{array}{l}1930.11-12 \\
1951.1\end{array}$ & $\begin{array}{l}\text { As above } \\
\text { As above }\end{array}$ & $\mid \begin{array}{ll}24^{\circ} & 25 \\
24^{\circ} & 32\end{array}$ & $\begin{array}{ll}118^{\circ} & 05^{\prime} \\
118^{\circ} & 07^{\prime}\end{array}$ & $\begin{array}{c}10.0 \\
6.8 \\
(8.2)\end{array}$ & $\begin{array}{l}120^{\circ} \text { E.M.T } \\
120^{\circ} \text { E.M.T }\end{array}$ & $\begin{array}{l}24(1-24) \\
24(1-24)\end{array}$ \\
\hline $1952,2-12$ & $\begin{array}{l}\text { Radso Plas } \\
\text { bill }\end{array}$ & $24^{\circ} 32^{\prime}$ & $118^{\circ} 07^{\prime}$ & $\begin{array}{c}6.8 \\
(8.2)\end{array}$ & $\begin{array}{l}t \pm 0 \text { zone } \\
t \pm \text { me }\end{array}$ & $24(1-24)$ \\
\hline $1953.1-12$ & He h1ll & $24^{\circ} 27^{\prime}$ & $118^{\circ} 04^{\prime}$ & {$\left[\begin{array}{c}40.6 \\
(43.7)\end{array}\right.$} & $\begin{array}{l}\text { time zone } \\
\text { time }\end{array}$ & $24(1-24)$ \\
\hline $1954.1-1957.12$ & As above & $24^{\circ} 27^{\prime}$ & $118^{\circ} 04^{\prime}$ & $\begin{array}{c}40.6 \\
(43,7)\end{array}$ & Local time & $4(1,7,13,19)$ \\
\hline 1938.1 & & $24^{\circ} 31^{\prime}$ & $118^{\circ} 09^{\circ}$ & $\begin{array}{r}23.4 \\
(23.8)\end{array}$ & Looal time & $4(1,7,13,19)$ \\
\hline $1960.9 \cdots 1967.8$ & Ralso flag & $24^{\circ} 31^{\prime}$ & $118^{\circ} 09^{\circ}$ & $\begin{array}{c}23.4 \\
(23.8)\end{array}$ & $\begin{array}{c}(B \bullet 1 J 1 n g \\
t \text { Im⿴) }\end{array}$ & $4(2,8,14,20)$ \\
\hline $1967.9-1980.12$ & Berolo h1ll & $24^{\circ} 27^{\prime}$ & $118^{\circ} 04^{\circ}$ & $\begin{array}{c}63.2 \\
(63,4)\end{array}$ & $\begin{array}{c}(B \in 1 J \text { Ins } \\
\text { tima) }\end{array}$ & $4(2,8,24,20)$ \\
\hline $1981.1-1983$ & & $24^{\circ} 29^{\prime} \mid$ & $118^{\circ} 04^{\prime}$ & 139.4 & 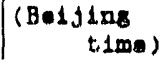 & $4(2,8,14,20)$ \\
\hline
\end{tabular}

C. Number of Obsarvations Used for Caloulatiog the Dally Moan

\begin{tabular}{|c|c|c|c|c|c|}
\hline Mean t1tas & $\begin{array}{c}\text { Moan proasuro } \\
\text { (Perlod) }\end{array}$ & $\begin{array}{r}\text { Tearporaturo } \\
\text { (Porlod) }\end{array}$ & $\begin{array}{l}\text { Rolative } \\
\text { humidity } \\
\text { (Poriod) }\end{array}$ & $\begin{array}{l}\text { Wind } \\
\text { (Porlod) }\end{array}$ & $\begin{array}{l}\text { Cloud } \\
\text { (Poriod) }\end{array}$ \\
\hline $\begin{array}{l}\text { (Maximumtanini } \\
\text { mum) } / 2 \\
3(6,14,21 \text { ) }\end{array}$ & $1934-1938.10$ & $1924-1928$ & & & $1934-1938.10$ \\
\hline $\begin{array}{l}8(3,6,9,12, \\
15,18,21,24)\end{array}$ & $1904-1930.20$ & $\begin{array}{l}1947-1950.5 \\
1929-1933\end{array}$ & $1947-1950.5$ & $1904-19300.10$ & $1934=1930.10$ \\
\hline $\begin{array}{l}16(6-21) \\
24(1-24)\end{array}$ & & $\begin{array}{l}1950.6-1953 \\
1915-1923\end{array}$ & $1950.6-1953$ & $\begin{array}{l}1950 \cdot 1-5 \\
1950.6-1953 \\
1924-1933\end{array}$ & $\begin{array}{l}1950.1-5 \\
1950.6-1953 \\
1924-1933\end{array}$ \\
\hline $\begin{array}{l}4(1,7,13,19) \\
4(2,8,14,20)\end{array}$ & $\mid \begin{array}{rr}1954-1960.7 \\
1960 & 8-1983\end{array}$ & $\begin{array}{l}1954-1960.7 \\
1960.8-1983\end{array}$ & $\begin{array}{l}1954-1960.7 \\
1960.8-1983\end{array}$ & $\begin{array}{l}1954-1960.7 \\
1960.8-1983\end{array}$ & $\begin{array}{l}1954-1960.7 \\
1960.8-1983\end{array}$ \\
\hline
\end{tabular}

D. Remarks:

1. Some records wera takon from data source (12) during 1951-1954 period. Location of station: $24^{\circ} 24^{\prime} 118^{\circ} 04^{\prime}$ ?. $2(M)$ in $1952.1-7$

$$
\begin{array}{lllll}
24^{\circ} & 24^{\circ} 118^{\circ} & 04^{\prime} & 10.7(M) & \text { in } 1952.8-12 . \\
24^{\circ} & 24^{\circ} 118^{\circ} & 07^{\prime} & 10.7(M) & \text { in } 1953 . \\
24^{\circ} 24^{\circ} 118^{\circ} 04^{\prime} 41.4(M) & \text { in } 1954^{\circ} .
\end{array}
$$


No. 5559265 Wu thou

A. Main Data Souroos

$\begin{array}{lr}\text { 1. } 1898 \sim 1957 & (145) \\ \text { 2. } 1924-1950 & (146) \\ \text { 3. } 1951-1960 & (153) \\ \text { 4. } 1951-1960 & (12) \\ \text { 5. } 1961-1970 & (149) \\ \text { 6. } 1981-1983 & (13) \\ \text { 7. } 1961-1970 \text { (moan/max/min tamporature } & (157) \\ \text { 8. } 1951.1-1953.2 & \text { (12) }\end{array}$

B. Loontion of Station, I'Imo Stondard and Ilmen of Obsorvations.

\begin{tabular}{|c|c|c|c|c|c|c|}
\hline $\begin{array}{l}\text { Obuervat d ovel } \\
\text { Period }\end{array}$ & Addrom: & $\left|\begin{array}{l}\text { Location } \\
\text { Lat. I }\end{array}\right|$ & $\mid$ of stati & $|\mathrm{fon}(\mathrm{M})(\mathrm{PB})|$ & $\mid \begin{array}{c}\text { TLene zone } \\
\text { sys tem }\end{array}$ & $\begin{array}{l}\text { Times of } \\
\text { observations }\end{array}$ \\
\hline $1898-1927$ & $\begin{array}{l}\text { Ardrolog 10 } \\
\text { atation }\end{array}$ & $23^{\circ} 39^{\prime} \mid$ & $\left|111^{\circ} 18^{\prime}\right|$ & & & \\
\hline $\begin{array}{l}1924-1928 \\
1929-1933\end{array}$ & $\begin{array}{l}\text { Cans thu } \\
\text { Cans thu }\end{array}$ & 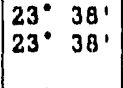 & $\begin{array}{ll}111^{\circ} & 177^{\prime} \\
111^{\circ} & 17^{\prime}\end{array}$ & $\begin{array}{l}10.7 \\
10.7\end{array}$ & $120^{\circ}$ E.M. I & $\begin{array}{l}8(3,6,9,12, \\
15,18,21,24)\end{array}$ \\
\hline $\begin{array}{l}1934-1944 \\
1931.1-9\end{array}$ & $\begin{array}{l}\text { Cang the } \\
\text { No.8 Bou At } \\
\text { road }\end{array}$ & 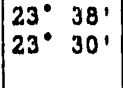 & $\begin{array}{l}111^{\circ} \\
111^{\circ} \\
25^{\prime}\end{array}$ & $\begin{array}{l}10.7 \\
43.8\end{array}$ & $\begin{array}{l}120^{\circ} \text { E.M.T } \\
105^{\circ} \text { E.M.T }\end{array}$ & $\mid \begin{array}{l}3(6,14,21) \\
16(6-21)\end{array}$ \\
\hline $1931.10-1952.10$ & $\begin{array}{l}\text { Xo.21 weste- } \\
\text { rn aldoy of } \\
\text { Wo1 X1n }\end{array}$ & $23^{\circ} 30^{\prime}$ & $111^{\circ} 25^{\prime}$ & 42.9 & $105^{\circ}$ E.M.T & $16(6-21)$ \\
\hline $1952.11-12$ & $\begin{array}{l}\text { No. } 19 \text { thu J1 } \\
\text { rond }\end{array}$ & $23^{\circ} 30^{\circ}$ & $111^{\circ} 25^{\prime}$ & 45.3 & $105^{\circ}$ E.M.T & $16(6-21)$ \\
\hline $\begin{array}{l}1953.1-12 \\
1954-1960.7\end{array}$ & $\begin{array}{l}\text { A bove } \\
\text { Pang bild } \\
\text { top }\end{array}$ & $\begin{array}{ll}23^{\circ} & 30^{\prime} \\
23^{\circ} & 29^{\prime}\end{array}$ & $\begin{array}{ll}111^{\circ} & 25^{\prime} \\
111^{\circ} & 18^{\prime}\end{array}$ & $\begin{array}{l}43.0 \\
119.2\end{array}$ & $\begin{array}{l}105^{\circ} \text { E.M.I } \\
\text { Lood moan } \\
\text { wolar timo }\end{array}$ & $\begin{array}{l}24(1-26) \\
4(1,7,13,19)\end{array}$ \\
\hline $1960,8-1903$ & As above & $23^{\circ} 29^{\prime}$ & $111^{\circ} 18^{\prime}$ & 119.2 & $\begin{array}{c}(B \circ 1\} 128 \\
\text { tino) }\end{array}$ & $4(2,8,14,20)$ \\
\hline
\end{tabular}

C. Number of Obanrvations Uaed for Caloulating the Dally Moan

\begin{tabular}{|c|c|c|c|}
\hline Moan timou & $\begin{array}{c}\text { Mean pressur } \\
\text { (Porlod) }\end{array}$ & $\begin{array}{r}\text { Texperature } \\
\text { (Portod) }\end{array}$ & $\begin{array}{l}\text { Relative } \\
\text { humidity } \\
\text { (Portod) }\end{array}$ \\
\hline (Maximontan 1 & & $\mid 1924-1928$ & \\
\hline & & $\begin{array}{l}1929-1933 \\
1934-1964\end{array}$ & $\begin{array}{l}1938,1-1943.10 \\
1944,1-\theta\end{array}$ \\
\hline $\begin{array}{l}24(1,24) \\
4(1,7,23,19) \\
4(2,8,14,20)\end{array}$ & $\begin{array}{l}1953,2-12 \\
1954-1960,7 \\
1960,8-1983\end{array}$ & $\begin{array}{l}1951-1953 \\
1954-1960.7 \\
1960.8-1983\end{array}$ & $\begin{array}{l}1931-1953 \\
1954-1960.7 \\
1960.8-1983\end{array}$ \\
\hline
\end{tabular}

D. Remarks:

1. Old nawe: "Cang tong " 
Ho. $56 \quad 59287$ Guang Zhou

A. Main Data Sourcea
1. $1908-1912$
(3)
$1938-1943$
(5)
2. $1912-1920$
(14)
4. $1951-1960$
(242)
5. $1961-1980$
6. $1928-1936$
7. $1981-1983$
Q. 1963-1965 (oloud aroount, dominant wiads)
$(6)(7)(8)(9)(10)(11)(143)$
(19)
(13) (243)
(156)

B. Looation of Station, Tloo Standard and Tlmes of Observationa.

\begin{tabular}{|c|c|c|c|c|c|c|}
\hline $\begin{array}{c}\text { Obaervationad } \\
\text { lariod }\end{array}$ & Addrass & $\left|\begin{array}{l}\text { Loont 1on } \\
\text { Lat. }\end{array}\right|$ & $\mid$ LOH, & $\left\{\begin{array}{l}\text { lon } \\
\mid \mathrm{B}(\mathrm{M})(\mathrm{PB})\end{array}\right.$ & $\begin{array}{c}\text { TIme ronu } \\
\text { sywt.mon }\end{array}$ & $\begin{array}{l}\text { Times of } \\
\text { obuervations }\end{array}$ \\
\hline $\begin{array}{l}1906-1912 \\
1912-1914.8\end{array}$ & $\begin{array}{l}\text { Agrioulture } \\
\text { colloge or } \\
\text { Zhoms Sha } \\
\text { univera } 1 \text { ty }\end{array}$ & $\left|\begin{array}{ll}23^{\circ} & 06^{\prime} \\
23^{\circ} & 08^{\prime}\end{array}\right|$ & $\left|\begin{array}{ll}113^{\circ} & 388^{\prime} \\
113^{\circ} & 17^{\prime}\end{array}\right|$ & $\begin{array}{r}8.8 \\
27.5\end{array}$ & $-a+n-\infty$ & $2(\cdots \cdots)$ \\
\hline $1914.9-1930.4$ & As abave & $23^{\circ} 08^{\prime}$ & $113^{\circ} 17^{\prime}$ & 27.5 & $\begin{array}{l}113^{\circ} E \\
\text { Locad moun } \\
\text { soler t tano }\end{array}$ & $\begin{array}{r}6(2,6,10,14 \\
18,21)\end{array}$ \\
\hline $.9331 .5-1937.8$ & As abova & $23^{\circ} 08^{\prime}$ & $113^{\circ} 17^{\prime}$ & 13.4 & $\begin{array}{l}113 \delta \pi \mathrm{E} \\
\text { Looal thean } \\
\text { solar than }\end{array}$ & $\begin{array}{r}6(2,6,10,14 \\
18,21)\end{array}$ \\
\hline $\begin{array}{l}1946.10-9 \\
1950-1952.4\end{array}$ & 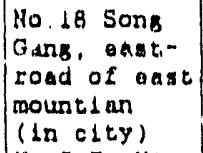 & $2,3^{\circ} 00^{\prime}$ & $123^{\circ} 13^{\prime}$ & 10.4 & $120^{\circ}$ E.H. I & $24(1-24)$ \\
\hline $1952.7-1953$ & $\begin{array}{l}\text { Ho.7 Fu Yin } \\
\text { roud, plum } \\
\text { blowaom } \\
\text { villagy }\end{array}$ & $23^{\circ} 00^{\prime}$ & $113^{\circ} 13^{\circ}$ & 18.0 & $220^{\circ}$ E.M.T. & $24(1-24)$ \\
\hline $1954.1-1957.6$ & As abova & $23^{\circ} 00^{\prime}$ & $113^{\circ} 13^{\circ}$ & 10.0 & $\left|\begin{array}{|l}\text { Looud thean } \\
\text { solar time }\end{array}\right|$ & $4(1,7,13,19)$ \\
\hline $1957.7-1960.7$ & $\begin{array}{l}\text { Tlan te } \\
\text { alrport. }\end{array}$ & $23^{\circ} 08^{\prime}$ & $113^{\circ} 19^{\prime}$ & 6.3 & $\begin{array}{l}\text { Loond woun } \\
\text { woLar timo }\end{array}$ & $h(2,7,23,29)$ \\
\hline $1960.8-1979$ & As above & $23^{\circ} 08^{\prime}$ & $113^{\circ} 19^{\prime}$ & $\begin{array}{l}6.3 \\
(7.6)\end{array}$ & $\begin{array}{c}(B \circ 1 J \operatorname{lng} 8 \\
\text { timo })\end{array}$ & $4(2,8,24,20)$ \\
\hline $1980-1983$ & & $23^{\circ} 00^{\prime}$ & $113^{\circ} 19^{\circ}$ & $\mid \begin{array}{l}6.6 \\
(7.6)\end{array}$ & $\mid \begin{array}{c}(8+1 j \operatorname{lng} 8 \\
t \operatorname{Lom} u)\end{array}$ & $4(2,8,14,20)$ \\
\hline
\end{tabular}

2. Rlumber of Observations Usod Lor Caloulating the Dally Man

\begin{tabular}{|c|c|c|c|}
\hline : Yean ticaes & $\begin{array}{c}\text { Mean prebaru } \\
\text { (Porlod) }\end{array}$ & $\begin{array}{r}\text { Tempezature } \\
\text { (Porlod) }\end{array}$ & $\begin{array}{l}\text { Rolative } \\
\text { humidity } \\
\text { (Perlod) }\end{array}$ \\
\hline 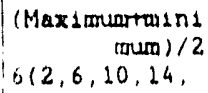 & & $\begin{array}{l}1924-1928 \\
1929-1933\end{array}$ & \\
\hline $\begin{array}{l}3(6,14,21) \\
24(1-24)\end{array}$ & $\begin{array}{l}1936-1937.8 \\
1940.10-1949.9 \\
1930-1933 \\
1930.5-1933\end{array}$ & $\begin{array}{l}1934-1937,8 \\
1940.10-1949,9 \\
1990-1953\end{array}$ & $\begin{array}{l}2948.10-1949.9 \\
1950-1953 \\
1912.2-1933\end{array}$ \\
\hline $\begin{array}{l}4(1,7,13,19) \\
4(2,8,14,20)\end{array}$ & $\begin{array}{l}1934-1960.7 \\
1960.8-1983\end{array}$ & $\begin{array}{l}1954-1960.7 \\
1960.8-1983\end{array}$ & $\begin{array}{l}1954-1960,7 \\
1960.8-1983\end{array}$ \\
\hline
\end{tabular}

D. Remarks: 
No. 5\% 59316 Ghan Tou

A. Maln Data Souroas
1. $1800-1943$
2. $1924-1942$
3. $1928-1936$
4. $1991-1.962$
5. $1963-1980$
6. $1981-1983$
7. 1963-1965 (proasuro, oLoud mourti and dominunt winda (156)

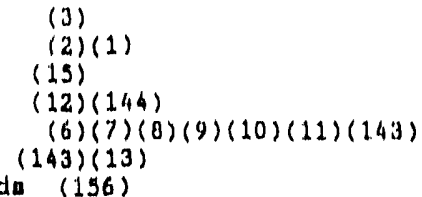

B. Looation of Station, Tlmo Standard and Tlmon of Obogrvationa,

\begin{tabular}{|c|c|c|c|c|c|c|}
\hline $\begin{array}{l}\text { buarvational } \\
\text { Parlud }\end{array}$ & Addrune & $\begin{array}{l}\text { ooatior } \\
\text { at. } N\end{array}$ & fof of atati & $|\forall(M)(P B)|$ & $\begin{array}{c}\text { Tima zono } \\
\text { symtions }\end{array}$ & arvatione \\
\hline 92.3 & $\begin{array}{l}\text { detmon whin- } \\
\text { Lon }\end{array}$ & $\left|23^{\circ} 21^{\prime}\right|$ & $116^{\circ} 60^{\prime}$ & 3.4 & $120^{\circ} \mathrm{E}, \mathrm{M}, \mathrm{Y}$ & \\
\hline $1924-1928$ & Aa abora & $23^{*} 21^{1}$ & $126^{\circ} \quad 40^{\prime}$ & 3,4 & $120^{\circ}$ E,M, I & 2. (Maxiantumini \\
\hline $1929-1933$ & Aa ubove & $23^{\circ} 22^{\prime}$ & $116^{\circ} 40^{\circ}$ & 3.4 & $120^{\circ}$ E.M. T & \\
\hline $\begin{array}{l}1934-1938,10 \\
1938,10-1942 \\
1951-1952.9\end{array}$ & $\begin{array}{l}\text { A. above } \\
\text { As above } \\
\text { No. } 311 \text { WalMa } \\
\text { rond in olty }\end{array}$ & $\begin{array}{ll}23^{\circ} & 21^{\prime} \\
23^{\circ} & 21^{\prime} \\
23^{\circ} & 20^{\prime}\end{array}$ & 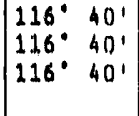 & $\begin{array}{l}3.4 \\
3.4 \\
2.1\end{array}$ & $\begin{array}{l}120^{\circ} \text { E.M.T } \\
120^{\circ} \text { E.M.T } \\
120^{\circ} \text { E.M.T }\end{array}$ & $\begin{array}{l}3(6,14,21) \\
24(1-24)\end{array}$ \\
\hline 12 & As above & $\left|\begin{array}{ll}233^{\circ} & 21 \\
23^{\circ} & 21^{1}\end{array}\right|$ & $\begin{array}{l}116^{\circ} 401 \\
116^{\circ} 40^{\prime}\end{array}$ & $\begin{array}{l}5,3 \\
3.3\end{array}$ & $\begin{array}{l}120^{\circ} \text { E.M. I I } \\
\text { Local moen } \\
\text { oolar time }\end{array}$ & $\begin{array}{l}24(1-24) \\
1(1,7,13,19)\end{array}$ \\
\hline $1953.9-1960.7$ & $\begin{array}{l}\text { Nour the Ko- } \\
\text { a roligtons } \\
\text { texple (nub- } \\
\text { urb) }\end{array}$ & $23^{\circ} 21^{\prime}$ & $216^{\circ} 40^{\prime}$ & 5.3 & $\begin{array}{l}\text { Loand moun } \\
\text { moler tidmo }\end{array}$ & $4(1,7,13,19)$ \\
\hline 1960. & As abov & $23^{\circ} 211^{\prime}$ & $116^{\circ} 40^{\prime}$ & 4,3 & 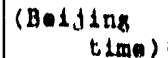 & $4(2,0,14,20)$ \\
\hline $1966-1983$ & AN above & $23^{\circ} 24^{\prime}$ & $116^{\circ} 41^{\prime}$ & $\begin{array}{c}1,2 \\
(3,3)\end{array}$ & $\begin{array}{r}(B \in 1, j \text { In: } \\
\text { tidmo })\end{array}$ & $4(2,0,14,20)$ \\
\hline
\end{tabular}

C. Number of Obanevationa Usud Por Caloulatidng the Dafly Mean

\begin{tabular}{|c|c|c|c|c|}
\hline Moun t.lma: & $\begin{array}{c}\text { Menn pronaure } \\
\text { (pertod) }\end{array}$ & $\mid \begin{array}{r}\text { Tamperature } \\
\text { (Porlod) }\end{array}$ & $\begin{array}{l}\text { Rolatidve } \\
\text { humidilyy } \\
\text { (Porlod: }\end{array}$ & $\begin{array}{l}\text { Wind } \\
\text { (Foriod) }\end{array}$ \\
\hline $\begin{array}{c}(\operatorname{Max} 1 \text { mumtmind } \\
\operatorname{mtan}) / 2 \\
B(3,6,9,12,15, \\
10,21,24) \\
3(6,14,21)\end{array}$ & & $\begin{array}{l}1924-1928 \\
1929-1933 \\
1934-1938,10 \\
1938,10 \cdots 1942\end{array}$ & $1930(7-12)$ & \\
\hline $\begin{array}{l}24(1-2,24) \\
4(1,7,13,19) \\
4(2,0,14,20)\end{array}$ & $\begin{array}{l}1951-1953 \\
1934-1960.7 \\
1960.801983\end{array}$ & $\begin{array}{l}19511-1953 \\
1954-1960.7 \\
1960.8-1983\end{array}$ & $\begin{array}{l}1.951-1959 \\
1954-1960,7 \\
1960.8-1903\end{array}$ & $\begin{array}{l}1952-1953 \\
1934-1960,7 \\
1960.8-1903\end{array}$ \\
\hline
\end{tabular}

D. Rernurke: 


\section{$13-60$}

$\mathrm{Ho}, 50$

99431 Hari HLns

A. Maln Data Sucurous

1. $1907.9-1950$

2. $1935-1950$

3. $1922-1950$

4. $1946-1950$

5. $1931-1960$

b. $1961-1970$

1. $1971-1980$

8. $1981-1903$

9. 1961-1970 (muan/max/m1n timposaturo

and o Loud amount) (197)

10. 1939-1936 (pramause, oloud actount, and whida)

B. Loontion of Station, TImo Utandard arid THow of Obugrvations,

\begin{tabular}{|c|c|c|c|c|c|c|}
\hline $\begin{array}{c}\text { Obourvationad } \\
\text { Pordod }\end{array}$ & Addraua & $\begin{array}{l}\text { Loontidon } \\
\text { Lent.N }\end{array}$ & $\mid \begin{array}{c}\text { of a tat } \\
\text { L,ON, }\end{array}$ & $|\operatorname{lon}(M)(P I I)|$ & $\begin{array}{c}\text { Titon zorio } \\
\text { syotom }\end{array}$ & $\begin{array}{l}\text { Tlman of } \\
\text { observatians }\end{array}$ \\
\hline $1907-1949$ & $\begin{array}{l}\text { Ugalrologin } \\
\text { ntutidon }\end{array}$ & $22^{\circ} 48^{\prime}$ & $\left|100^{\circ} 22^{\prime}\right|$ & & & \\
\hline $1922-1939$ & $\begin{array}{l}\text { Clidmatalosi- } \\
\text { oul observa- } \\
\text { tion attation }\end{array}$ & $22^{\circ} 422^{\prime}$ & $100^{\circ} 16^{\prime}$ & $\begin{array}{c}76.0 \\
(76,7)\end{array}$ & $120^{\circ}$ E.M.T & $3(6,14,21)$ \\
\hline $1946-1950.3$ & & $22^{\circ} 42^{\prime}$ & $100^{\circ} 16^{\circ}$ & $\begin{array}{l}76.0 \\
(76.7)\end{array}$ & $105^{\circ}$ E.M.T & $3(6,14,21)$ \\
\hline $\begin{array}{l}1950.6-1951 \\
1954.1-1996.8\end{array}$ & & 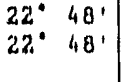 & $\left|\begin{array}{l}108^{\circ} \\
100^{\circ} \\
100^{\prime} \\
10^{\prime}\end{array}\right|$ & $\begin{array}{l}74.0 \\
714.9\end{array}$ & $\begin{array}{l}105^{\circ} \text { E.M.T. } \\
\text { looal monn } \\
\text { solar thlmol }\end{array}$ & $\begin{array}{l}24(1-24) \\
4(6,7,23,19)\end{array}$ \\
\hline $1956.9-1960.7$ & & $22^{\circ} 51^{\prime}$ & $108^{\circ} 19^{\prime}$ & 122.3 & $\begin{array}{l}\text { Looal moan } \\
\text { solar tiano }\end{array}$ & $4(2,7,13,19)$ \\
\hline $1960,8-1965.9$ & & $22^{\circ} 49^{\prime}$ & $100^{\circ} 21^{\prime}$ & 122.3 & 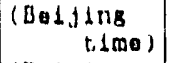 & $4(2,8,14,20)$ \\
\hline $1965 \cdot 10-1983$ & & $22^{\circ} 49^{\prime}$ & $108^{\circ} 21^{\prime}$ & 72,2 & $\left|\begin{array}{r}(B, 1 J 1 \mathrm{NB} \\
t \perp \mathrm{ma})\end{array}\right|$ & $11(2,8,14,20)$ \\
\hline
\end{tabular}

C. Nunbor of Obsarvations Haed foz Calculating tho Dally Moan

\begin{tabular}{|c|c|c|c|}
\hline Mean timas & $\left\{\begin{array}{c}\text { Moan pronaura } \\
\text { (Porlod) }\end{array}\right.$ & $\mid \begin{array}{r}\text { Tomporaturo } \\
\text { (Eortad) }\end{array}$ & $\begin{array}{l}\text { RoLatidvo } \\
\text { humidity } \\
\text { (Poxiod) }\end{array}$ \\
\hline $3(6,14,21)$ & & $\begin{array}{l}1922-1935.6 \\
1946-1949 \\
1937-1939\end{array}$ & $1935 \times 1944$ \\
\hline $\begin{array}{l}24(1-24) \\
4(1,7,13,19)\end{array}$ & $\begin{array}{c}1950-19 ! 3 \\
1954-1960.7\end{array}$ & $\begin{array}{l}1950-1953 \\
1994-1960.7 \\
1960.8-1983\end{array}$ & $\begin{array}{l}1990-1953 \\
1950.3-6 \\
1954-1960.7 \\
1960.8-1983\end{array}$ \\
\hline
\end{tabular}

0. Rernarka:

i. Old natne: "Yons NIns" 
A. Maln Data Souroea
1. $1913 \cdot 1953$
(1.56)
2. $1931-1940$
$(191)$
3. $1991+1960$
4. $1961-1900$
3. $1981-1903$
6. 1963-1069 (prowaure, aloud amotmi, dominarit nirda)
$(143)(6)(7)(8)(9)(10)(11)$
(13) $(143)$
(1.56)

H. Loontion of Station, TIme standard and Timos of Obanervationa,

\begin{tabular}{|c|c|c|c|c|c|c|}
\hline $\begin{array}{l}\text { Obanrvational } \\
\text { Pariod }\end{array}$ & Addrnum & $\begin{array}{l}\text { Looatior } \\
\text { Liat. N }\end{array}$ & $\int_{\text {Lot }}$ of $\mathrm{E}$ tat & $\log _{\theta(M)(B A)}$ & 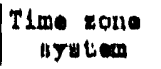 & $\begin{array}{l}\text { Tlman of } \\
\text { obeervatilone }\end{array}$ \\
\hline $1913-1936$ & $\begin{array}{l}\text { Cuwtmon wtim- } \\
\text { tilom }\end{array}$ & $21^{\circ} 03^{\prime}$ & $110^{\circ} 251$ & 14.0 & & \\
\hline $\begin{array}{l}1921-1936 \\
1936-1940 \\
1950.6-1953\end{array}$ & $\begin{array}{l}\text { An abrre } \\
\text { No.1 Min You }\end{array}$ & $\begin{array}{ll}21^{\circ} & 03^{\prime} \\
22^{\circ} & 03^{\prime} \\
21^{\circ} & 02^{\prime}\end{array}$ & 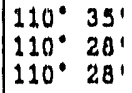 & $\begin{array}{l}14,0 \\
14,0 \\
10,0\end{array}$ & $\begin{array}{l}109^{\circ} \text { E,M.T } \\
120^{\circ} \text { E,M,I }\end{array}$ & $\begin{array}{l}3(3,7,13) \\
24(1-24)\end{array}$ \\
\hline $19.94,1-10$ & $\begin{array}{l}\text { road its oity } \\
\text { A. above }\end{array}$ & $21^{\circ} 02^{\prime}$ & $110^{\circ} 28^{\prime}$ & 10.0 & Looal mean & $1(1,7,13,19)$ \\
\hline $1954,11-1960,7$ & 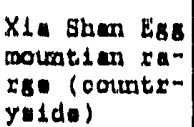 & $21^{\circ} 02^{\prime}$ & $110^{\circ} 28^{\prime}$ & 26.4 & $\begin{array}{l}\text { Lopal moan } \\
\text { colar timo }\end{array}$ & $1(1,7,13,19)$ \\
\hline & As abova & $21^{\circ} 02^{\prime}$ & $110^{\circ} 28^{\prime}$ & 26.4 & $\begin{array}{l}\text { (Bodjung } \\
\text { time) }\end{array}$ & $4(2,8,14,20)$ \\
\hline $1974-1978$ & & $2.1^{\circ} 13^{\prime}$ & $110^{\circ} .241$ & 29.1 & 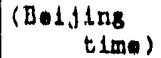 & $4(2,8,24,20)$ \\
\hline $1979-1903$ & & $21^{\circ} 13^{\prime}$ & $110^{\circ} 24^{\prime}$ & 25.3 & $\begin{array}{c}(B \cdot d j \operatorname{lns} \\
t \text { ima })\end{array}$ & $4(2,0,14,20)$ \\
\hline
\end{tabular}

C. Numbar of Obuervationn Uned for Ealoulating the Dally Mnan

\begin{tabular}{|c|c|c|c|c|}
\hline Moan timou & $\begin{array}{c}\text { Moan proasuro } \\
\text { (Partod) }\end{array}$ & $\mid \begin{array}{r}\text { Temporature } \\
\text { (Porlod) }\end{array}$ & $\mid \begin{array}{l}\text { Rolatidve } \\
\text { humiditiy } \\
\text { (Pordod) }\end{array}$ & $\begin{array}{l}\text { Wind } \\
\text { (Pordod) }\end{array}$ \\
\hline $\begin{array}{l}\text { (Maximumtroind } \\
\quad \text { mum) } / 3 \\
3(6,14,21) \\
24(1-24) \\
4(1,7,13,19) \\
4(2,8,24,20)\end{array}$ & $\begin{array}{l}1953,8-12 \\
1994-1960,7 \\
1960,8-1983\end{array}$ & $\begin{array}{l}1921-1936 \\
1950,6-12 \\
1951-1953 \\
1954-1960.7 \\
1960,8-1903\end{array}$ & $\begin{array}{l}1950,6-12 \\
1951-1953 \\
1954-1960,7 \\
1960,8-1983\end{array}$ & $\begin{array}{l}1931-1933 \\
1934-1960,7 \\
1960,8-1903\end{array}$ \\
\hline
\end{tabular}

D. Ramarka: 


\section{B $3-68$}

Ho. $60 \quad 59 \% 58$ Hat i...

A. Main Uatia Sourcos

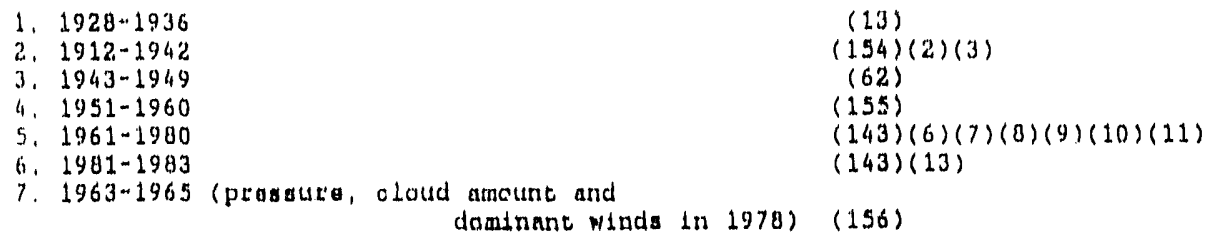

B. Location of Station, Tho Standard and I'Imos of Obsarvationis,

\begin{tabular}{|c|c|c|c|c|c|c|}
\hline $\begin{array}{l}\text { Daservationad } \\
\text { Porlad }\end{array}$ & Addrous & $\left|\begin{array}{l}\text { Looatiog } \\
\text { Lat.N }\end{array}\right|$ & $\left\{\begin{array}{l}\text { of atat } \\
\text { LON, } E\end{array}\right.$ & $|B(M)(P B)|$ & $\begin{array}{c}2 \text { ime zone } \\
\text { aystem }\end{array}$ & $\begin{array}{l}\text { Thmos of } \\
\text { obmorvations }\end{array}$ \\
\hline $\begin{array}{l}1912-1923 \\
1924 * 1928\end{array}$ & $\left|\begin{array}{l}\text { Qong mount } 1 \text { an } \\
\text { Qons mountilan }\end{array}\right|$ & $\left|\begin{array}{ll}20^{\circ} & 011^{\prime} \\
20^{\circ} & 011^{\prime}\end{array}\right|$ & $\mid \begin{array}{ll}110^{\circ} & 16^{\prime} \\
110^{\circ} & 16^{\prime}\end{array}$ & $\begin{array}{l}2.7 \\
2.7\end{array}$ & $\left|\begin{array}{ll}105^{\circ} & \text { E.M.T.T } \\
105^{\circ} & \text { E.M.T }\end{array}\right|$ & 2 (Maxtenumtont \\
\hline $1929 \cdot 1933$ & Qons mount 1 an & $20^{\circ} 01^{\prime}$ & $110^{\circ} 16^{\prime}$ & 2.7 & $105^{\circ}$ E.M.T & $\begin{array}{l}8(3,6,9,12, \\
15,10,21,24)\end{array}$ \\
\hline $\begin{array}{l}1934- \\
1951,1-1953,4 \\
1953,5-1\end{array}$ & $\begin{array}{l}\text { Qong mountdan } \\
\text { Alrport } \\
\text { Had Kou asfp- }\end{array}$ & $\begin{array}{ll}20^{\circ} & 01^{\prime} \\
20^{\circ} & 00^{\prime} \\
20^{\circ} & 00^{\circ}\end{array}$ & $\begin{array}{ll}110^{\circ} & 16^{\prime} \\
110^{\circ} & 25^{\prime} \\
110^{\circ} & 25^{\prime}\end{array}$ & $\begin{array}{r}2.7 \\
16.1 \\
16.1\end{array}$ & $\begin{array}{l}105^{\circ} \text { E.M.T } \\
120^{\circ} \text { E.M.T } \\
120^{\circ} \text { E.M.T }\end{array}$ & $\begin{array}{l}3(6,14,21) \\
24(1-24) \\
24(1-24)\end{array}$ \\
\hline $1953.8-12$ & $\begin{array}{l}\text { Ort. } \\
\text { No. } 2 \text { Wan MIng } \\
\text { dast road } \\
\text { (suburb) }\end{array}$ & $23^{\circ} 30^{\prime}$ & $110^{\circ} 25^{\prime}$ & 2.8 & $120^{\circ} E, M, T$ & $24(1 \cdot 24)$ \\
\hline $1954 \times 1957.4$ & $\begin{array}{l}\text { Long di vili- } \\
\text { asw of Ziliong } \\
\text { town thicd } \\
\text { diatrict (co- } \\
\text { untryado) }\end{array}$ & $20^{\circ} 00^{\prime}$ & $110^{\circ} 25^{\prime}$ & 1.4 .4 & $\begin{array}{l}\text { Loond toan } \\
\text { solar titna }\end{array}$ & $4(1,7,13,19)$ \\
\hline $1957.5-1960.7$ & As above & $20^{\circ} 00^{\prime}$ & $110^{\circ} 25^{\prime}$ & 14.1 & $\begin{array}{l}\text { Looal moan } \\
\text { solar tima }\end{array}$ & $4(1,7,13,19)$ \\
\hline 1930.001968 & $\begin{array}{l}\text { Fu Chong town } \\
\text { Qong mountian } \\
\text { oolanty (coun- } \\
\text { tiryoido) }\end{array}$ & $20^{\circ} 011$ & $110^{\circ} 211^{\prime}$ & 17.6 & $\begin{array}{c}(B+1 j \operatorname{lng} \\
\text { tima) }\end{array}$ & $4(2,8,14,20)$ \\
\hline $1969-1983$ & As above & $20^{\circ} 021$ & $110^{\circ} 211$ & 14.1 & $\left(\begin{array}{c}(\theta)+\ln g \\
\operatorname{tin} \theta)\end{array}\right.$ & $4(2,8,14,20)$ \\
\hline
\end{tabular}

C. Hunber of Obarvations Used for Caloulatidig tho Dally Hean

\begin{tabular}{|c|c|c|c|c|}
\hline Moan t.dines & $\left\{\begin{array}{c}\text { Mean prossuro } \\
(\text { Portod })\end{array}\right.$ & $\left\{\begin{array}{l}\text { Temperalura } \\
(\text { Defled })\end{array}\right.$ & $\begin{array}{l}\text { Relativa } \\
\text { humidity } \\
\text { (Pariod) }\end{array}$ & $\begin{array}{l}\text { Wind } \\
\text { (Yorlod) }\end{array}$ \\
\hline $\begin{array}{r}(\text { Haximum+mind } \\
\text { mum) } / 2\end{array}$ & & $1924-1928$ & & \\
\hline $\begin{array}{r}3(3,6,9,12,15 \\
10,21,24)\end{array}$ & $1928-1933$ & $1.928-1933$ & $1928-1933$ & $1928-1933$ \\
\hline $\begin{array}{l}3(6,24,21) \\
24(1 \cdot 24)\end{array}$ & $\begin{array}{l}1934-1936 \\
1951-1953.7\end{array}$ & $\begin{array}{l}1934-1936 \\
1951-1953\end{array}$ & $\begin{array}{l}1934-1936 \\
1951-1953\end{array}$ & $\begin{array}{l}1934-1936 \\
1951-1953\end{array}$ \\
\hline $4(1,1,13,19)$ & $1954.3-1960.7$ & $1954.3-1960.7$ & $1954.3-1960.7$ & $1954,3-1960,7$ \\
\hline $4(2,8,14,20)$ & $1960,8-1983$ & $1960.8-1983$ & $1960.8-1983$ & $1960,8-1983$ \\
\hline
\end{tabular}

i). Renarks:

$\therefore$ Old name: " Zong mountain" 
APPENDIX C

SOURCES OF DATA FOR THE PRC 60-STATION CLIMATE DATA SET 
C-3

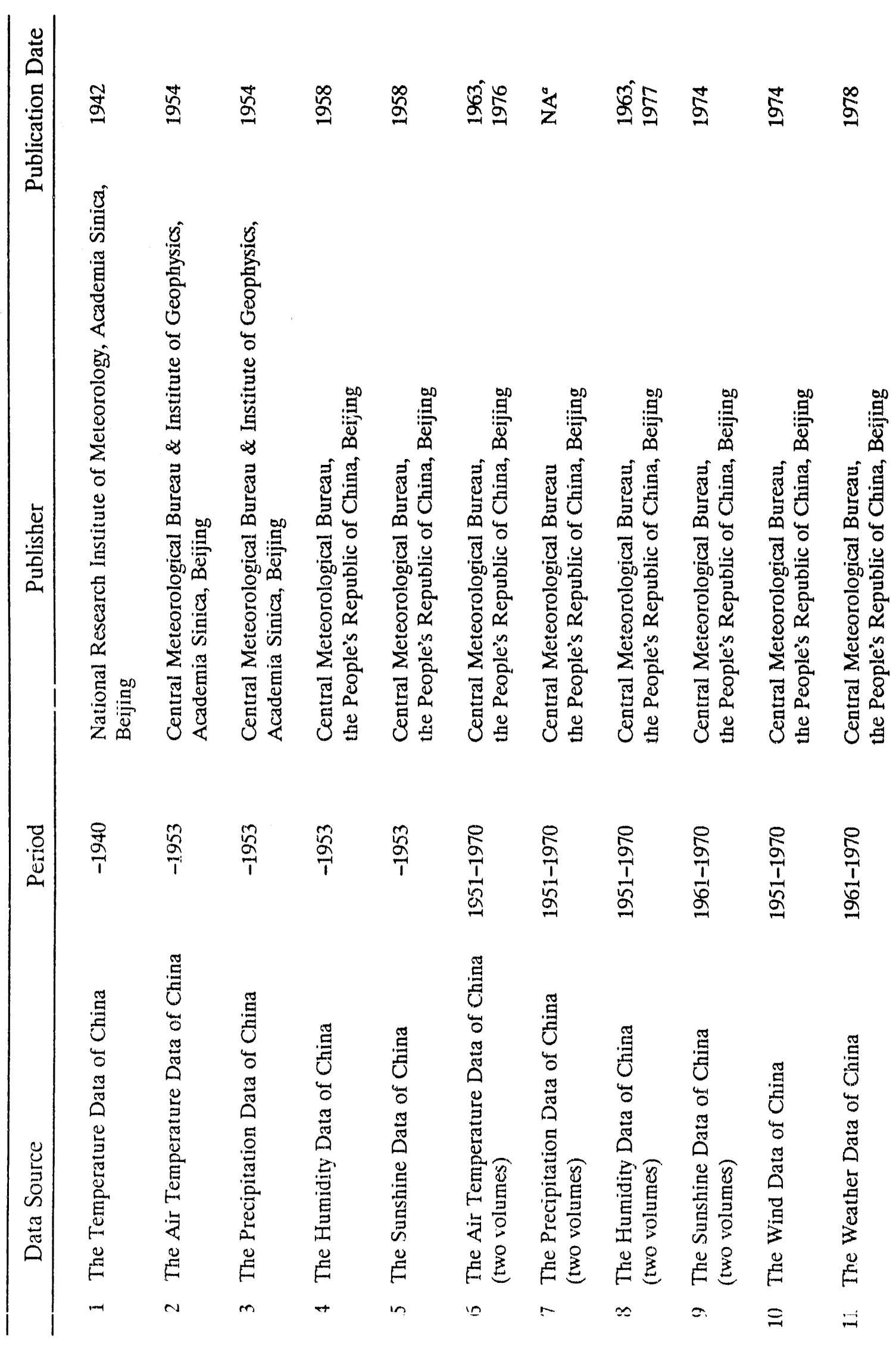


C-4

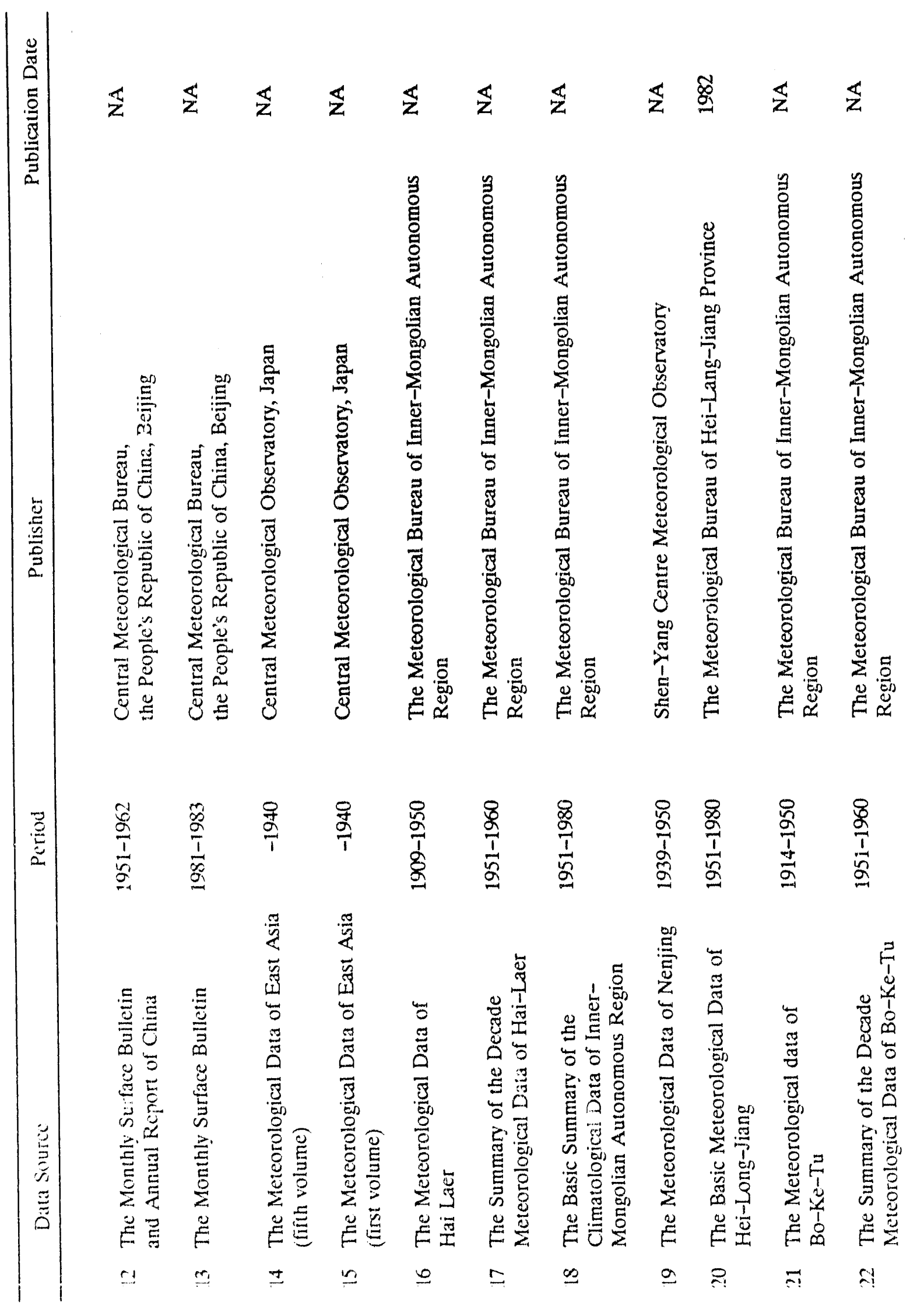


C-5

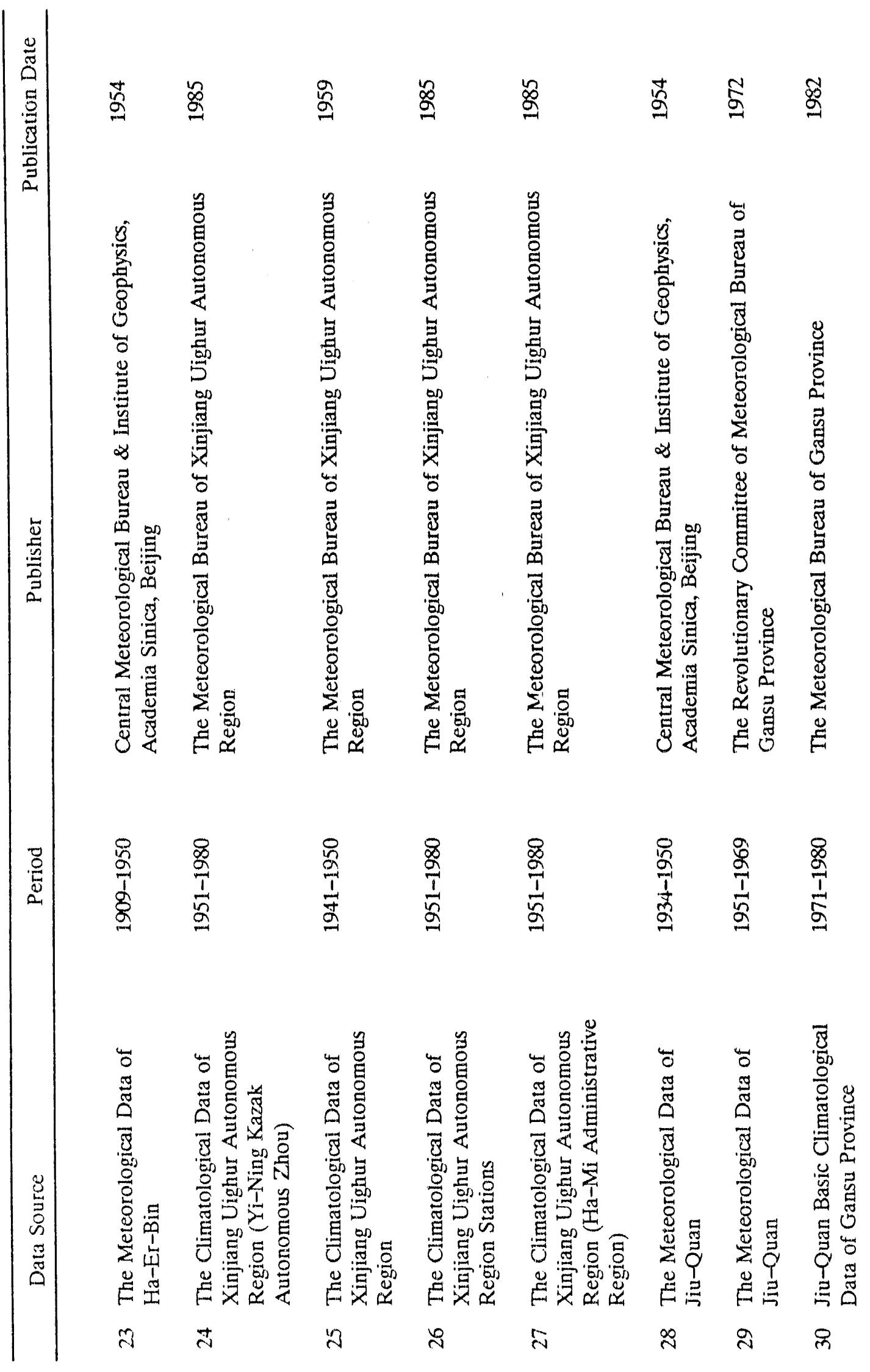


C. 6

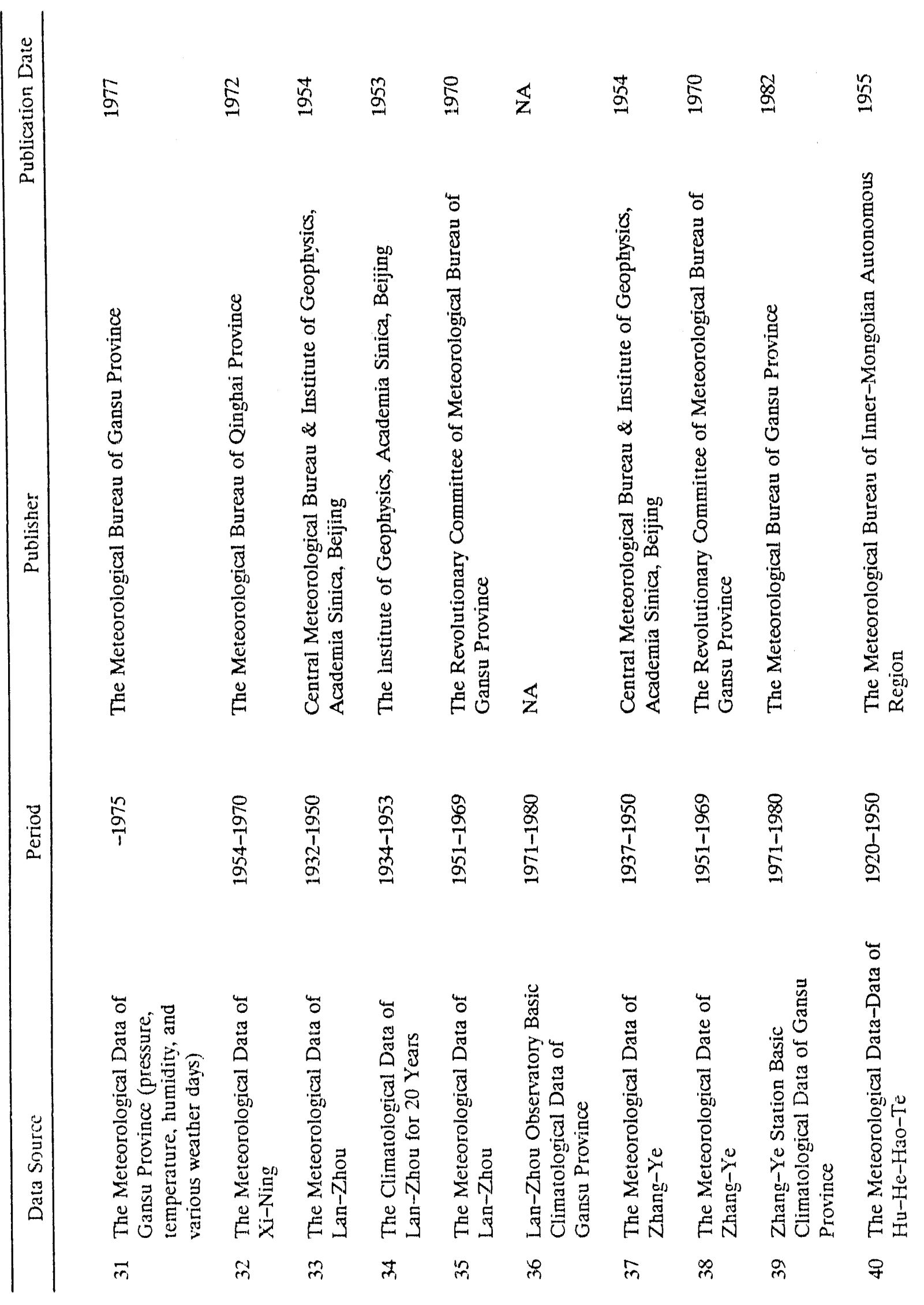




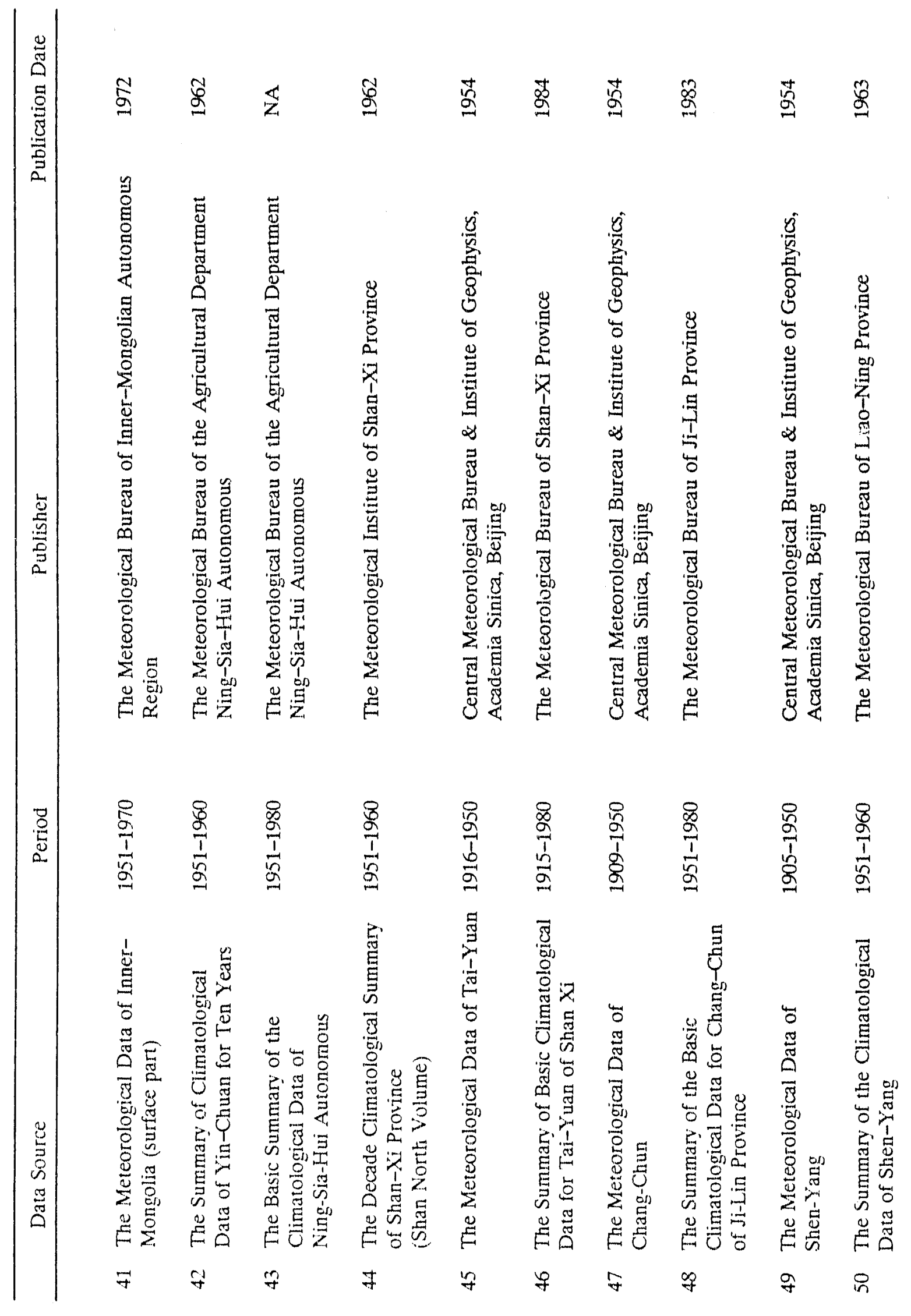


C. 8

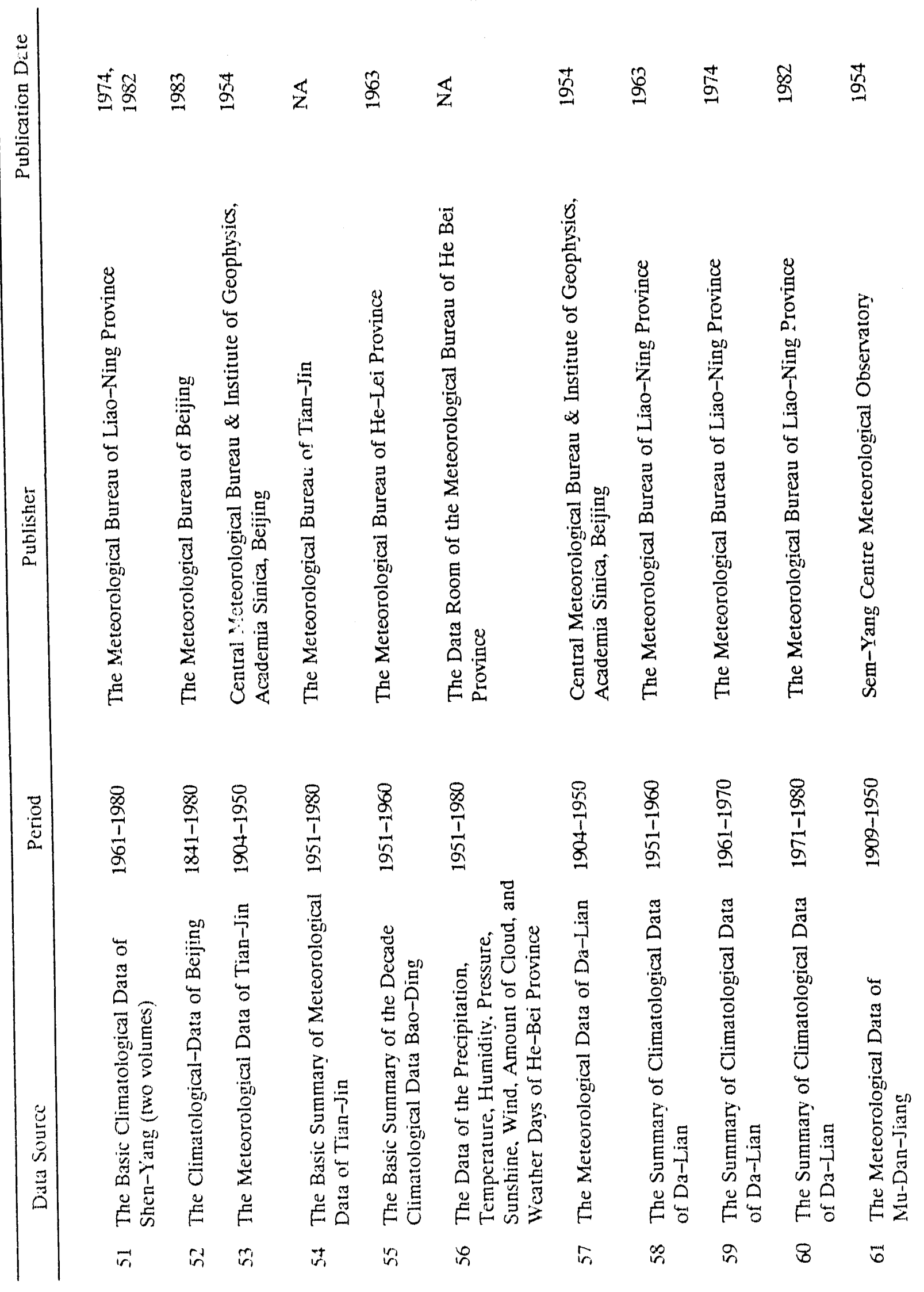




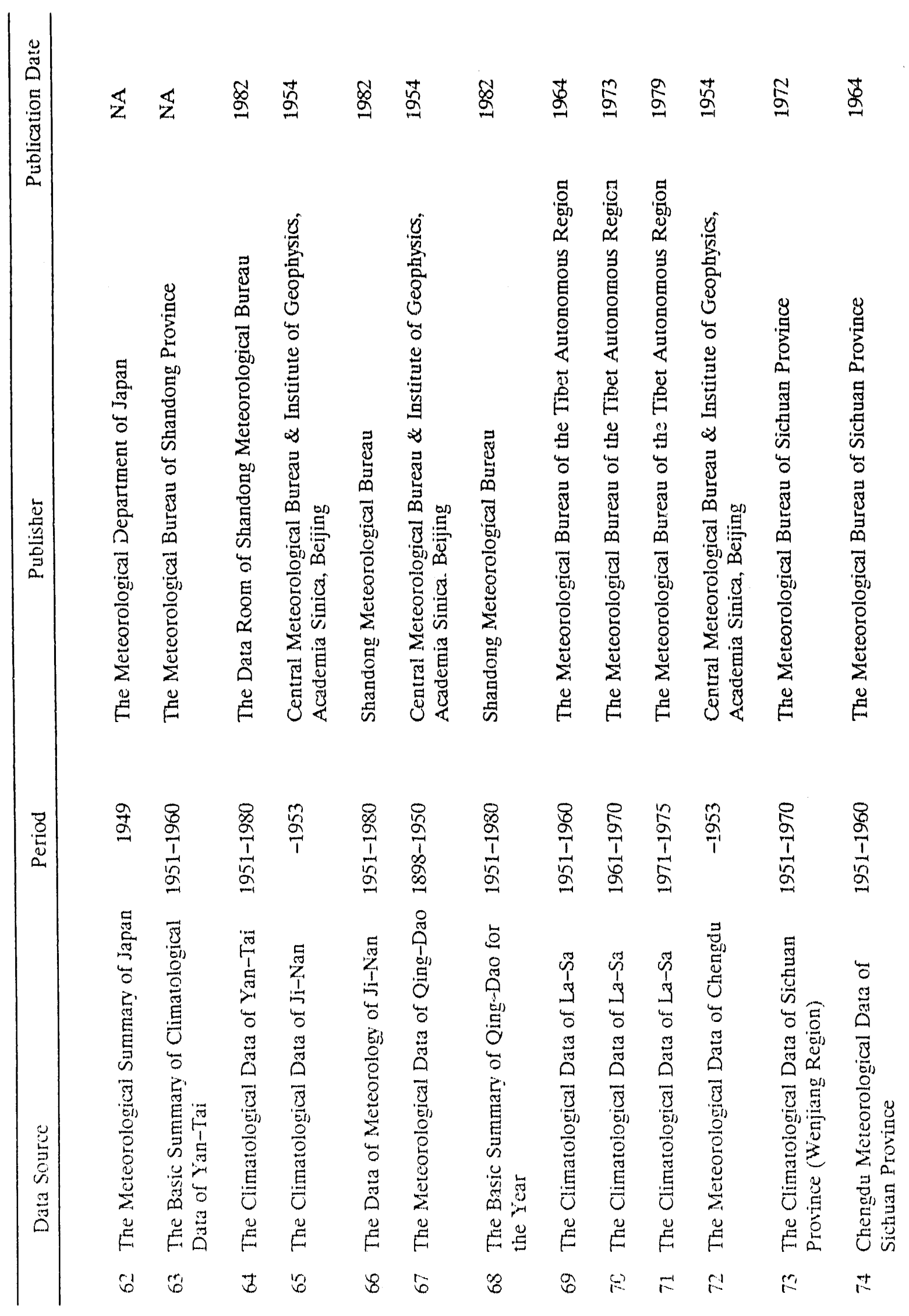


C. 10

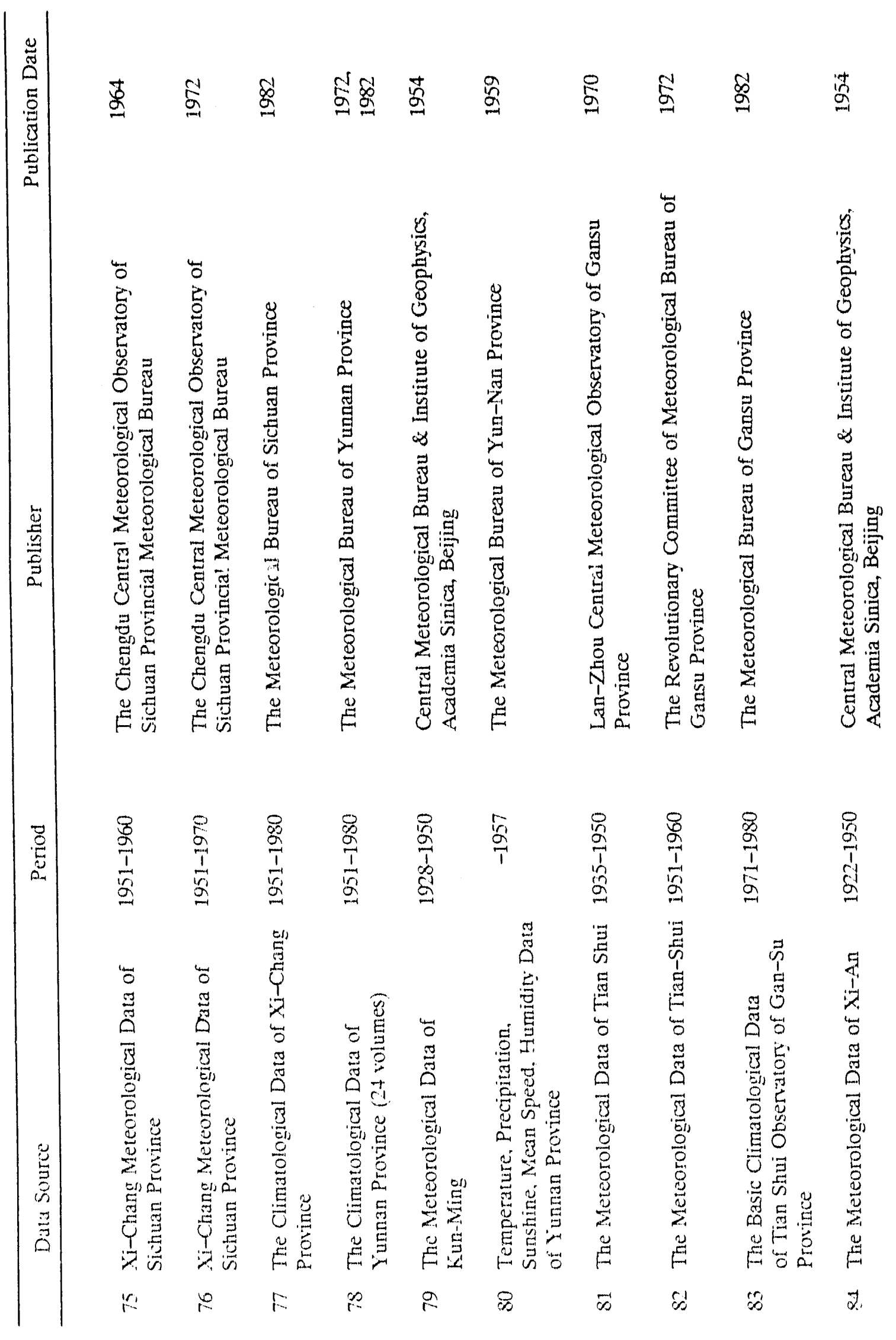


C. 11

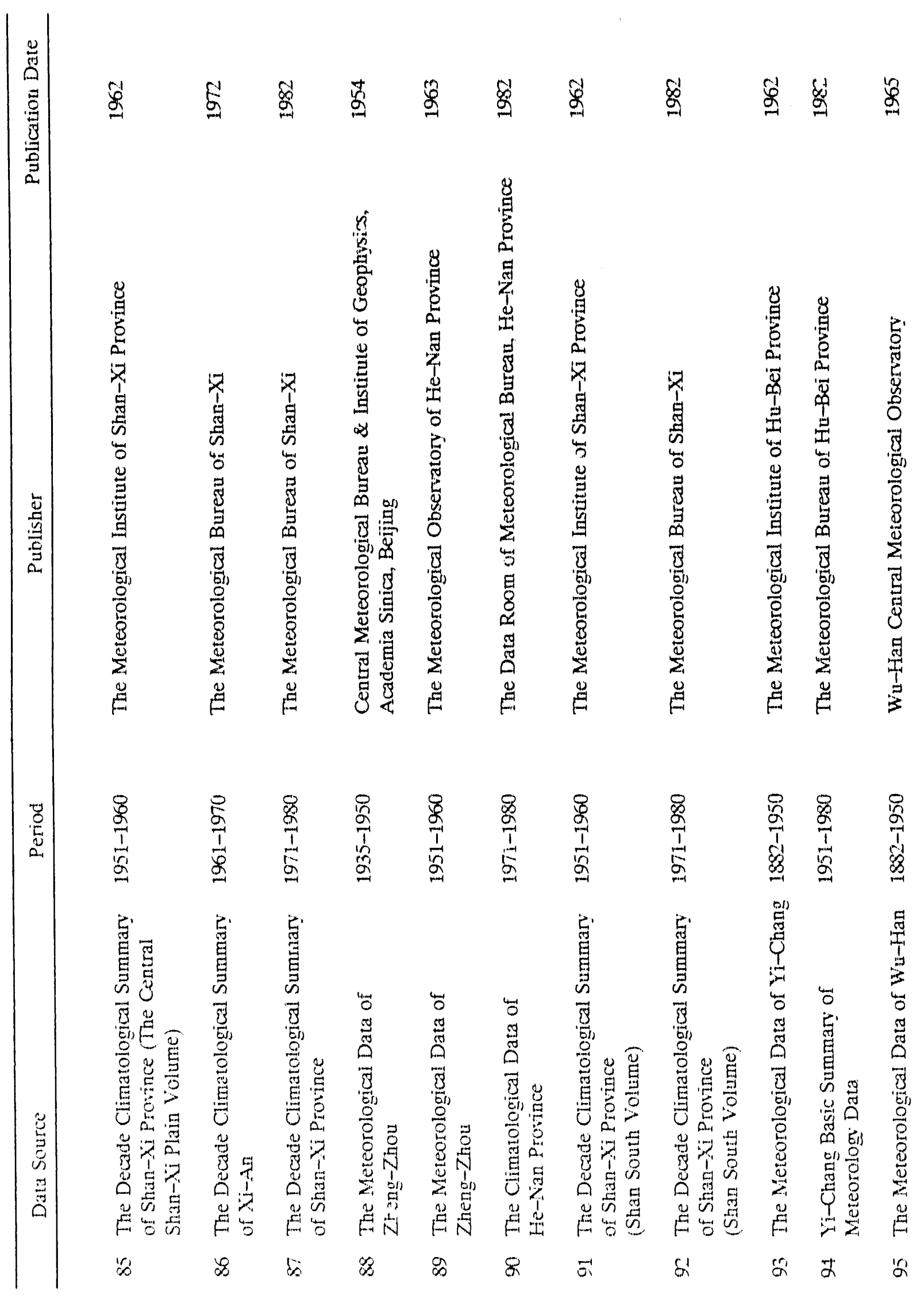




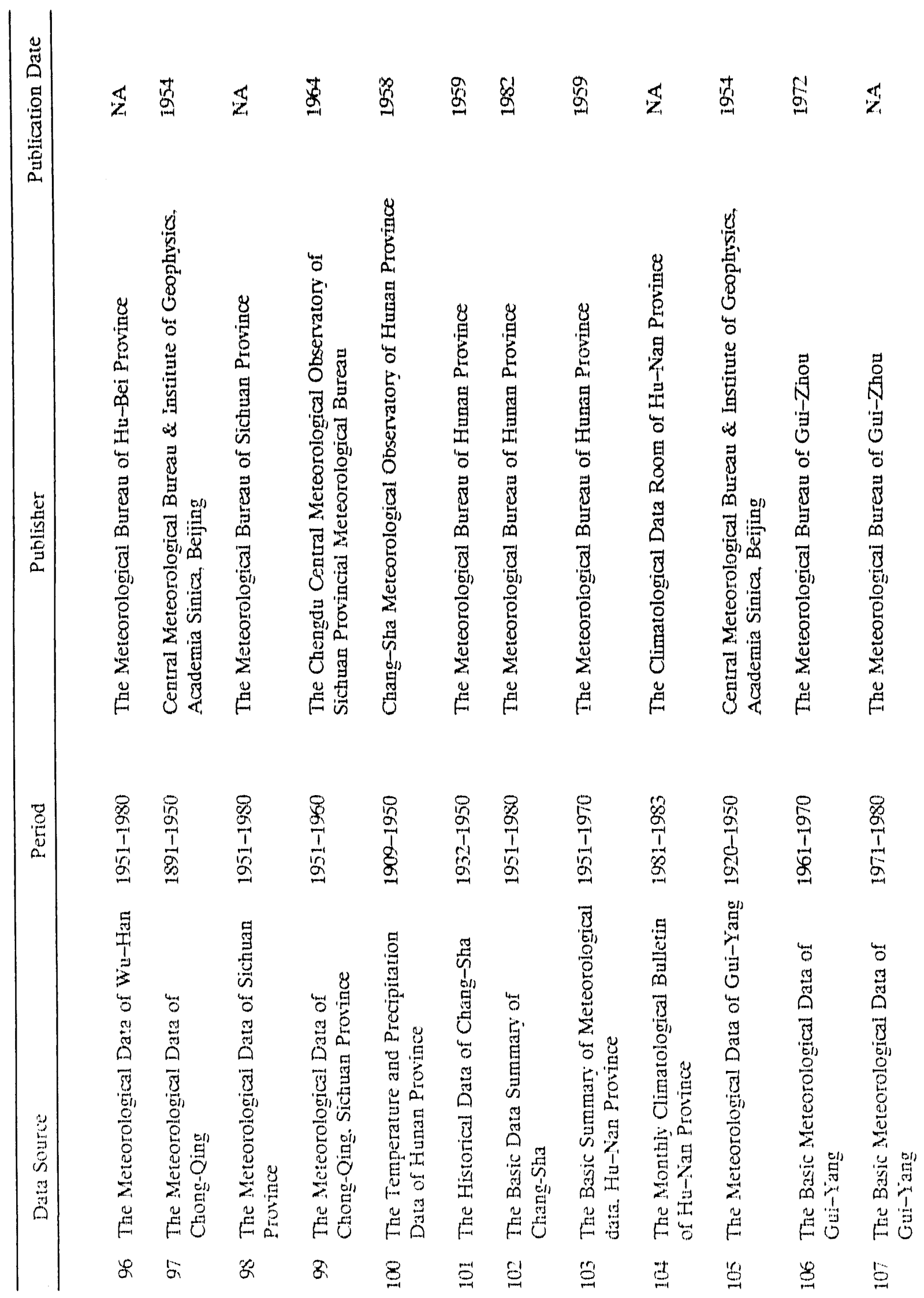




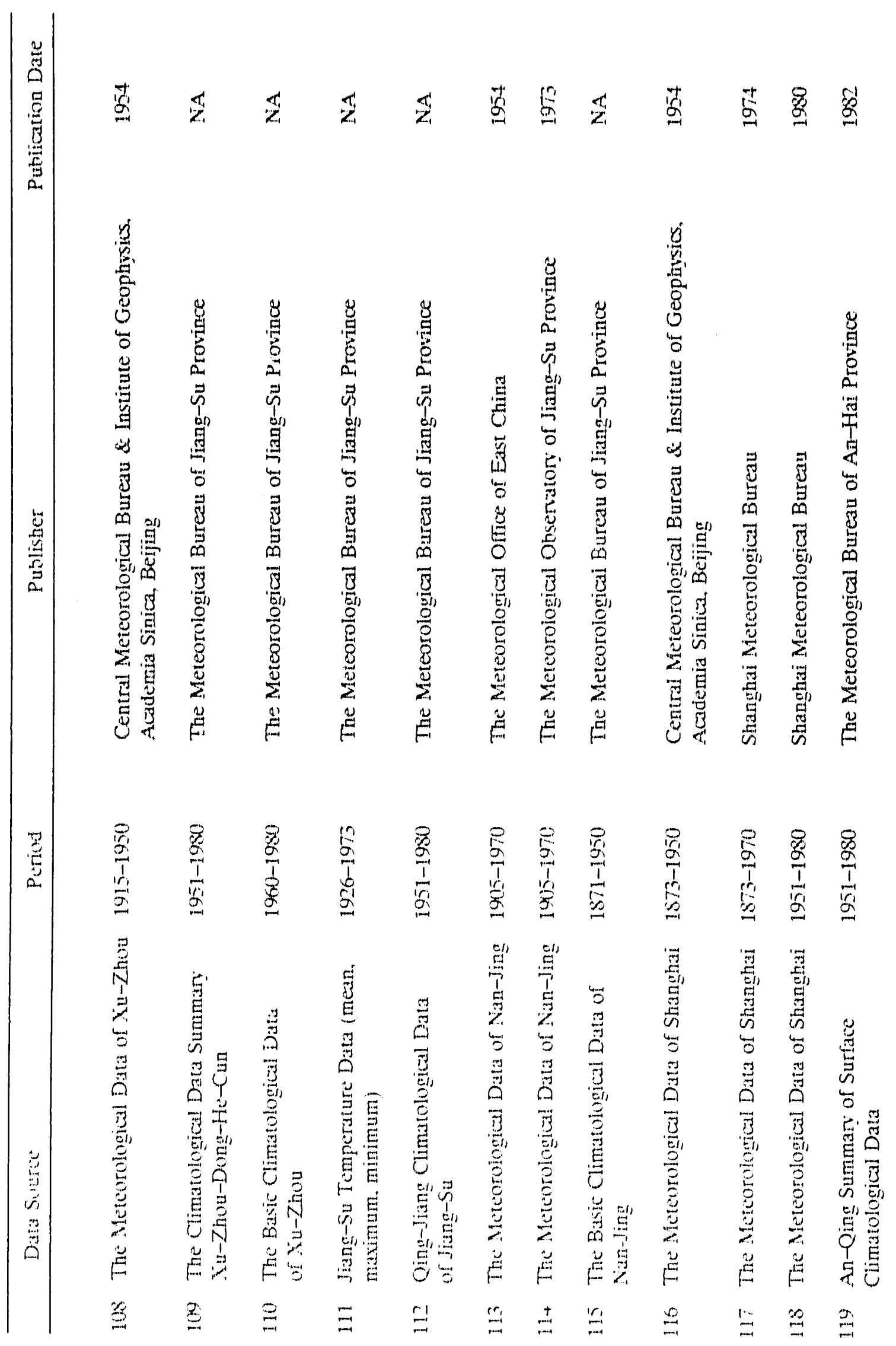


C. 14

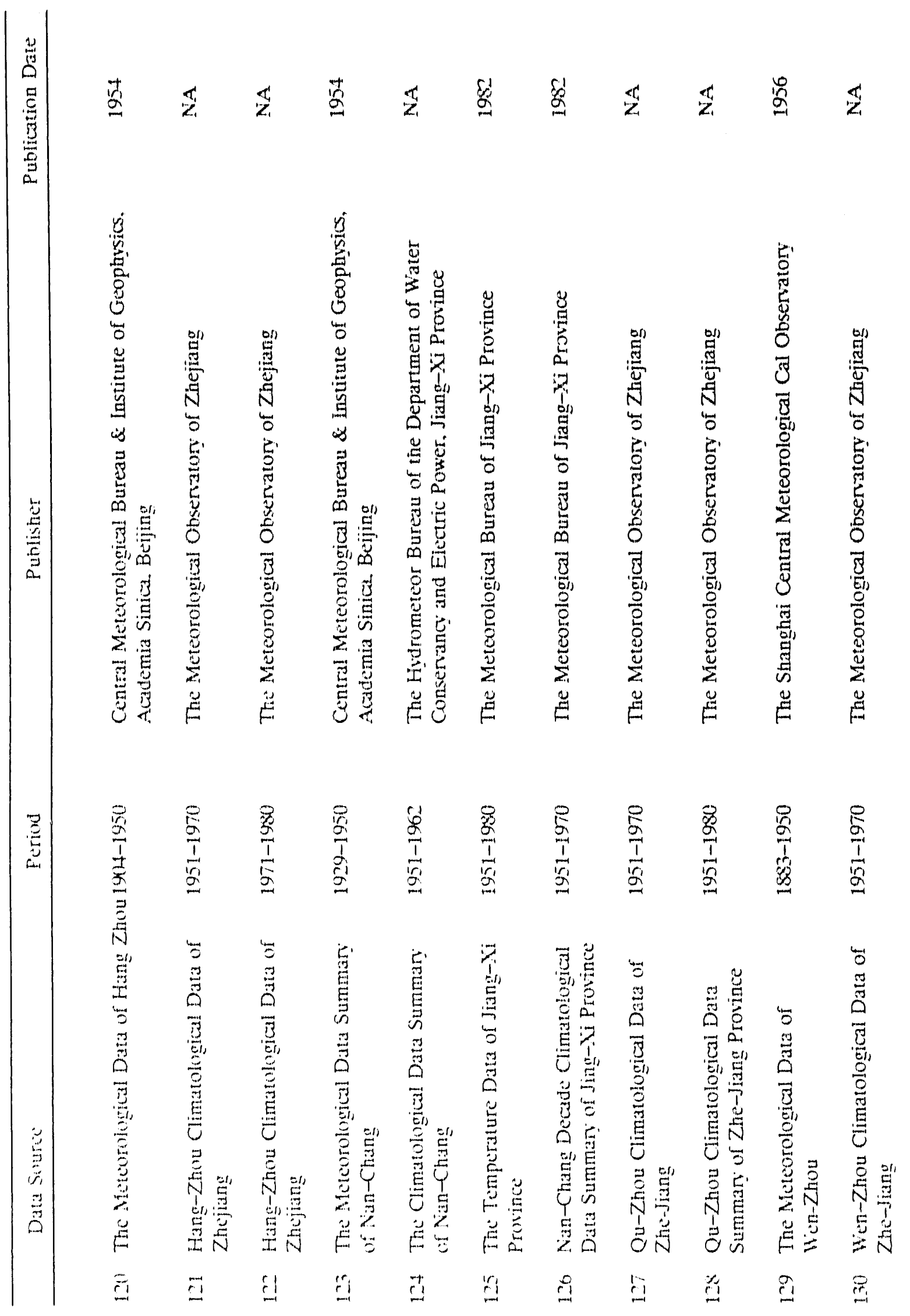


C. 15

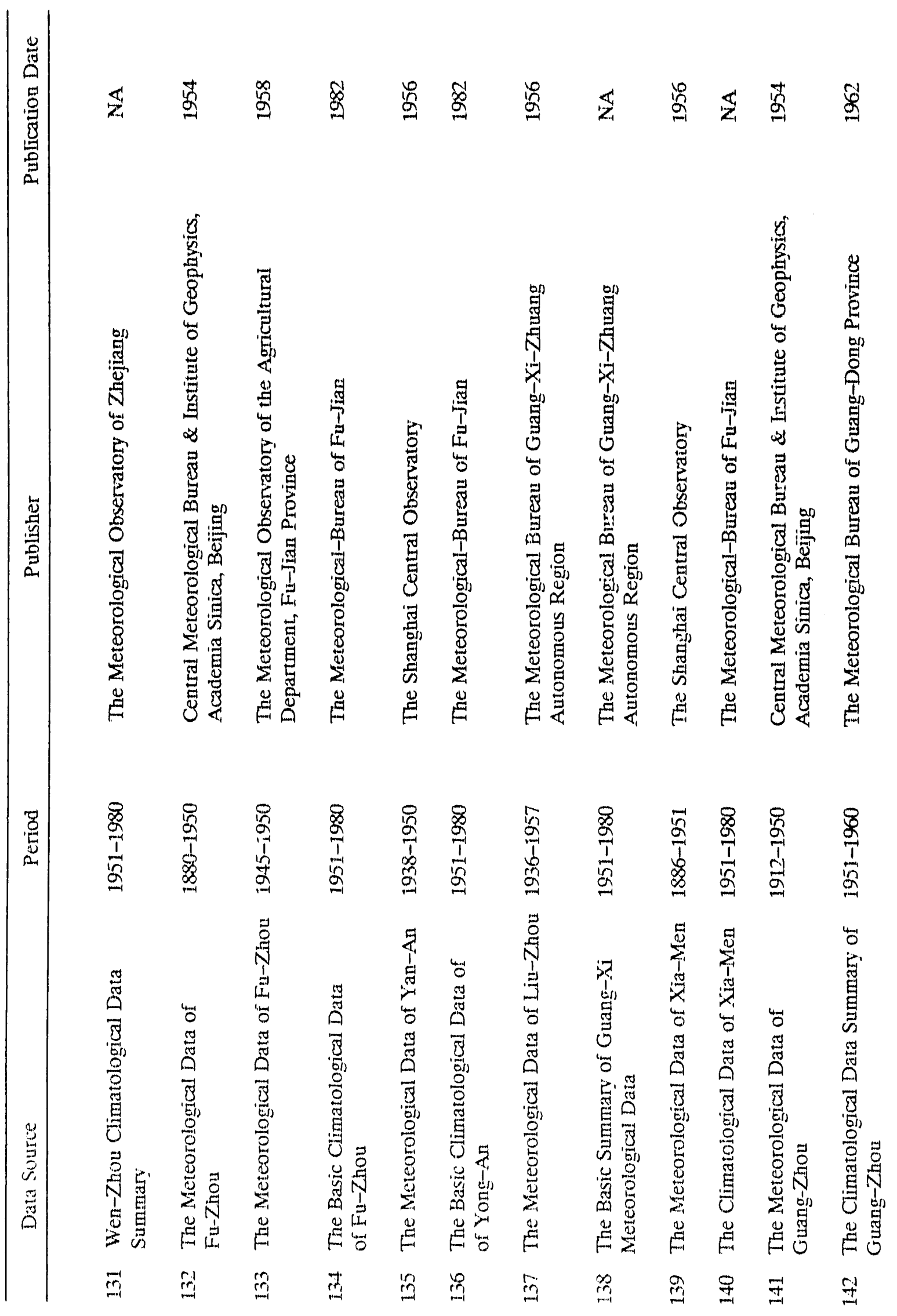


C- 16

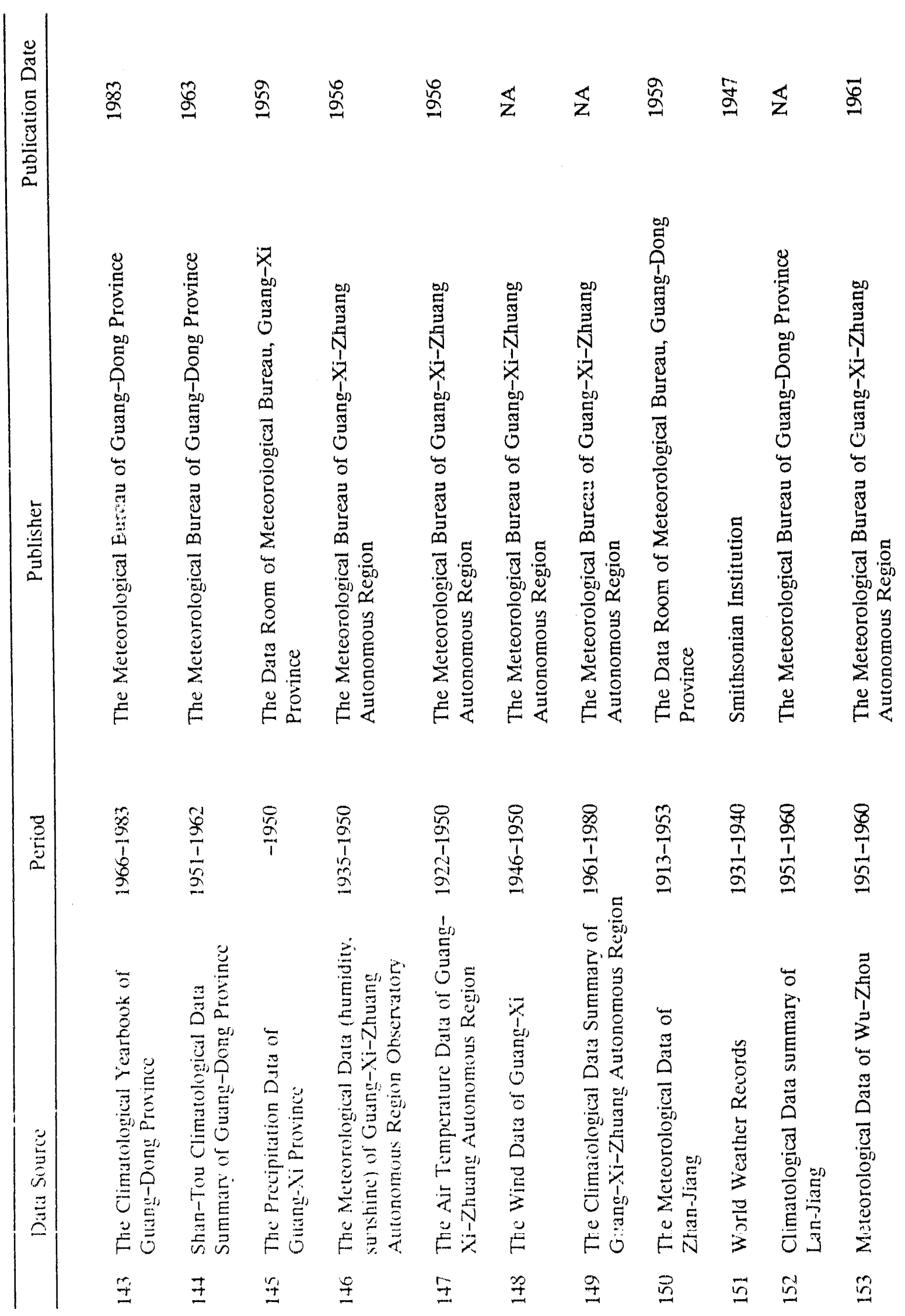


C-17

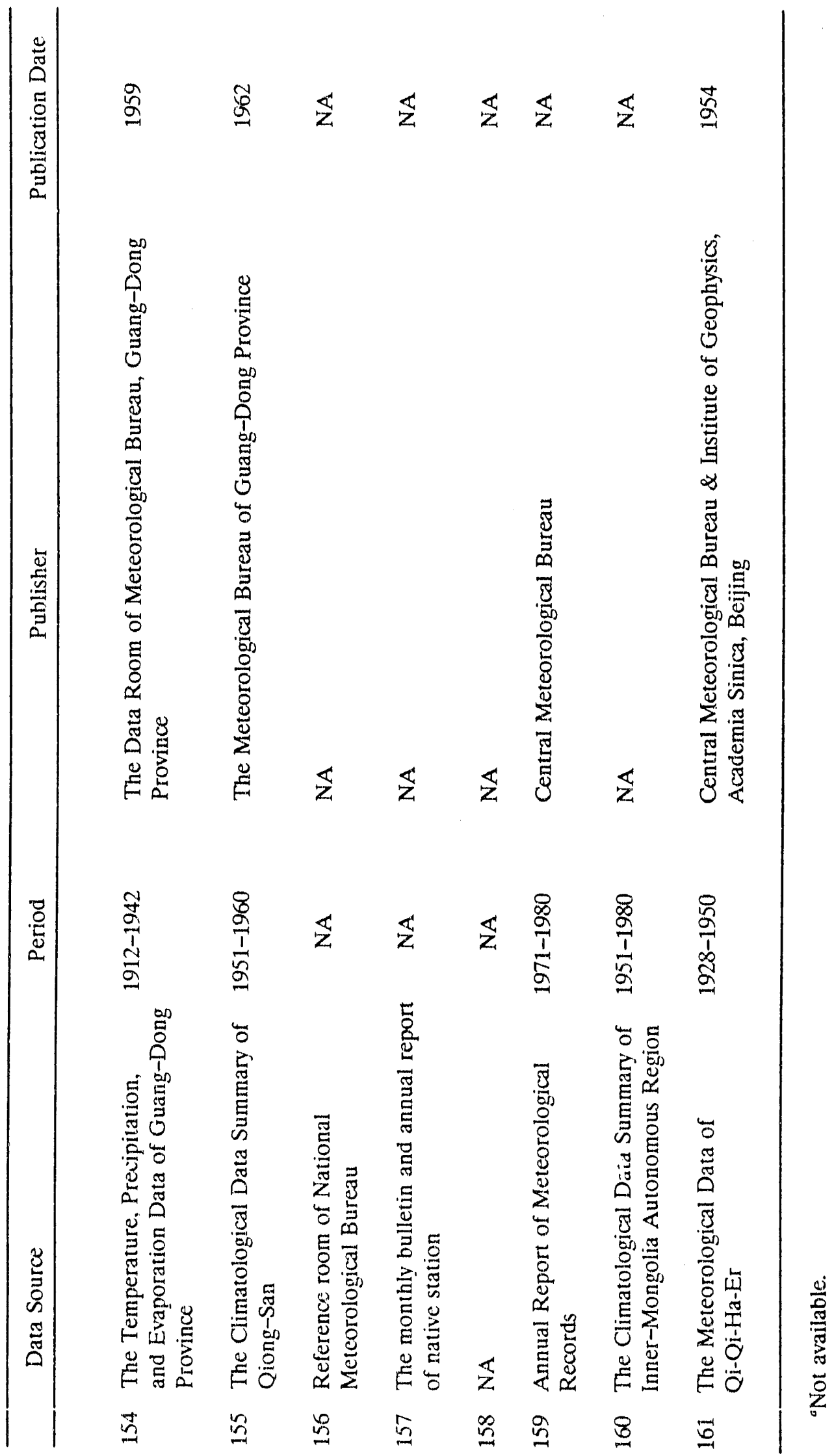


APPENDIX D

REPRTNTS OF PERTINENT LITERATURE

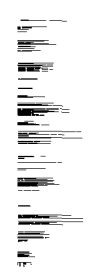


D-3

GEOPHYSICAL. RESEARCH LETTERS, VOL. 17, NO. 12, PAOES 2377-2.380, DECEMBER 1990

\title{
URBAN HEAT ISLANDS IN CHINA
}

\author{
Wei-Chyung Wang1, Zhaomei Zeng 1,2, Thomas R. Karl ${ }^{3}$
}

\begin{abstract}
Abstracs. We used 1954-1983 surface temperature from 42 Chinese urban (average population $1.7 * 106$ ) and rural (average population $1.5 * 105$ ) station pairs to study the urban heat island effects. Despite the fact that the rutal stations are not true rural stations, the magnitude of the heat islands was calculated to average $0.23^{\circ} \mathrm{C}$ over the thirty-year period with a minimum value during the 1964-1973 decade and maximum during the most recent decade. The urban heat islands were found to have seasonal dependence which varied considerably across the country. The urban heat islands also had a strong regional dependence with the Northern Plains dominating tho magnitude of the heat islands. The changes in heat island intensity over three decades studied suggest a general increase in heat island intensity of ahout $0.1^{\circ} \mathrm{C}$, but this has not been constant in time. These results suggest that caution must be exercised when attributing causes to observed trends when stations are located in the vicinity of metropolitan areas.
\end{abstract}

\section{Introduction}

In recent years conceins were raised about whether the observed increase in atmospheric greenhouse gases was the main cause for the observed increases in the global mean surface temperature of $\sim 0.5^{\circ} \mathrm{C}$ during the last hundred years (see WMO/UNEP, 1990 for a review). These concerns intensified after the 1988 abnormal weather of record high temperature and drought conditions in many regions of the United States and record storms sweeping over Europe. In addition, the 1980's have been documented as the warniest decade on record. Many of these weather anomalies are not inconsistent with the simulations from the general circulation models, which also predict a substantial ginbal warming in the next few decades if the currellt increasing trends for greenhouse gases continue. A global warming will have serious implications on regional weather and climate with subsequent effects on economic and social activities. Active research has been focused on climate model development to improve regional climate prediction and on observations to delect the greenhouse warming signals (CES, 1989).

One area of the detection issue has focused on the credibility of greenhouse warming attribution in the global temperature trend when many stations are located in the vicinity of major urban areas (Wood, 1988; Karl and Quayle, 1988; Karl et al., 1988; Jones et al., 1990). Regional studies indicate that there exists a significant urban heat island effect in the United States; in some cases it can introduce bias of $0.1 \cdot 0.3$ ${ }^{\circ} \mathrm{C}$ per decade in the temperature trend.

Karl et al. (1988) and Balling and Idso (1989) have studied the relationship between population change and urban warming bias in the United States and the correlations were found to be statistically sipnificant. Karl et al. (1988) have

\footnotetext{
IAtmospheric Sciences Research Center, State University of New York

${ }^{2}$ Institute of Atmospheric Physics, Chinese Academy of Sciences, Beijing, China

${ }^{3}$ National Climatic Data Center, NESDIS/NOAA, Ashevi!le, North Carolina

Copyright 1990 by the American Geophysical Union.

Paper number 9061.02300

$0094-8276 / 90 / 90 G L_{-}-02300 \$ 03.00$
}

developed an empirical relation to correct the urban warming hias irt the United States Historical Climate Network (HCN). Even in this mostly rural network of stations, a warm bias of about $0.06{ }^{\circ} \mathrm{C}$ occurs during the twentieth century due to population growth around observing sites.

Both the United States and China are located in midlatitudes with comparable land areas. However, the climates of the two countries are different due to the different topographical and geographic coriditions. In addition, there are considerable differences in the non-climatic factors such as the energy consumption, industrialization and population density, which may affect the temperature trends and the magnitude of the urban bias. Consequently, the urban warming bias in China may have a different pattern than that found in the United Siates.

Several empirical studies have already been conducted to study the urban heat island effects in China (see Zhou and Zhang, 1985 for a review). However, these studies focused on either the big cities such as Shanghai or the comparative study between a big city and the suburbs for one or two selected cities (see Chow, 1986). Here we perform a study of the urban warming bias in the Eastern half of China using many stations. Our work differs from the recent study by Jones et al. (1990). They have shown that any urban bias in their data has been mitigated over Eastern China. The reasons for this are not clear. Our intent is to determine the magnitude and scope of heat islands in China and determine whether there is evidence of any change in theis intensity over the past few decades.

\section{Analysis}

The temperature data used in this study are based on 42 . pairs of urban-rural stations from a 260)-station temperature data set recently compiled under the United States' Department of Energy and People's Republic of China's Academy of Sciences joint research program on the greenhouse effect (Koomanoff et al., 1988). The temperatures cover the period up to 1983. For some stations, the data dated back to the nineteenth century, for example, Beijing from 1841 and Shanghai from 1873 .

Data from selected 84 rural and urban stations includes monthly mean temperatures for the period 1954-1983. The period was chosen mainly because most stations were established by 1954 and continuous records exist. We grouped the 42-pairs into six regions: (I) Northeast, (II) Northern Plains, (III) Middle-Lower Changjiang and Huaihe Basin, (IV) Southeast Coast, (V) Southwest and (VI) Northwest; each region had seven station pairs (see Figure 1). Discussion of the geophysical features and climate characteristics of these regions can tre found in Domros and Peng (1988). Figure 1 also shows the locations of the station pairs, and the averaged station heights, populations and linear trends over separate urtan and rural stations for the individual regions. These stations primarily cover the, Eastern part of China. They were chosen based on station histories: selected stations have relatively few, if any, changes in instrumentation, location, or observation times over this period. Additional criteria used to choose the 42-pairs urban-rural stations are: as small as nocsihle snatial dictance herween the indiuidua! pair; most stations with 1985 population of over one million for urban sites (average 1.71 million) and less than 0.2 miltion for rural sites (average 0.147 million); and suitability of topography, geographical location and the spatial location of the station network.

2377 


\section{D-4}

\begin{tabular}{|c|c|c|c|c|}
\hline Region & $\begin{array}{l}\text { Urban (U)/ } \\
\text { Rural (R) }\end{array}$ & $\begin{array}{l}\text { Height } \\
(\mathrm{m})\end{array}$ & $\begin{array}{l}\text { Population } \\
(1000)\end{array}$ & $\begin{array}{l}\text { Linear Trend } \\
\left({ }^{\circ} \mathrm{C} / 30 \text { years }\right)\end{array}$ \\
\hline \multirow[t]{2}{*}{1} & U & 172 & 1697 & 0.82 \\
\hline & $\mathbf{R}$ & 142 & 241 & 0.51 \\
\hline \multirow[t]{2}{*}{ II } & U & 67 & 2494 & 0.64 \\
\hline & $\mathbf{R}$ & 41 & 89 & 0.35 \\
\hline \multirow[t]{2}{*}{ III } & U & 47 & 1382 & 0.11 \\
\hline & $\mathbf{R}$ & 45 & 188 & 0.21 \\
\hline \multirow[t]{2}{*}{ IV } & U & 31 & 2025 & 0.10 \\
\hline & $\mathrm{R}$ & 29 & 59 & 0.05 \\
\hline \multirow[t]{2}{*}{ V } & $U$ & 726 & 1490 & -0.21 \\
\hline & $R$ & 647 & 162 & -0.14 \\
\hline \multirow[t]{2}{*}{$\mathrm{VI}$} & U & 1143 & 1212 & 0.70 \\
\hline & $R$ & 1073 & 144 & 0.44 \\
\hline \multicolumn{5}{|l|}{ China } \\
\hline & U & 363 & 1717 & 0.36 \\
\hline & $R$ & 330 & 147 & 0.24 \\
\hline
\end{tabular}

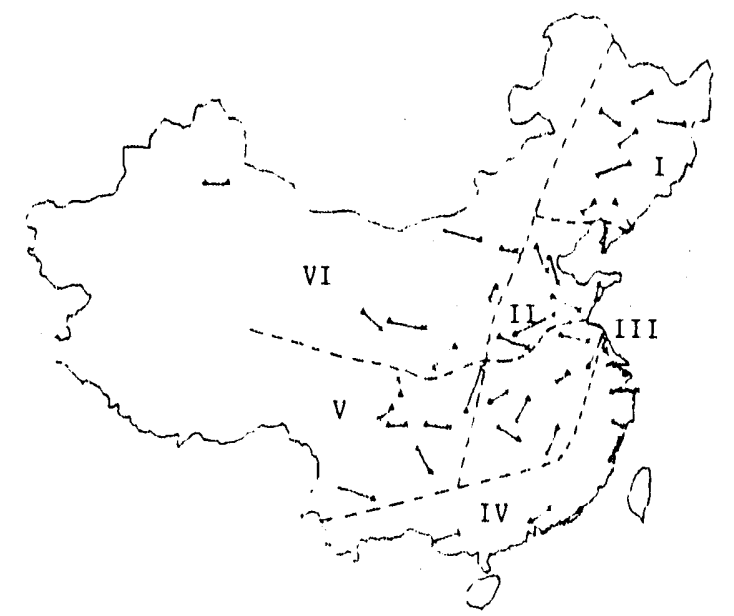

Fig. 1: The 42-pairs urban (in $\Delta$ ) and rural (in $X$ ) stations used to study the urban heat islands. The values of station heights, populations, and 30-year linear trends averaged over the separate urban and rural stations are calculated for six regions: (I) Northeast, (II) Northern Plains, (III) Middle-Lower Changjiang and Huaihe Basin, (IV) Southeast Coast, (V) Southwest, and (VI) Northwest. Note that the population statistics used are 1981-1985 averages for urban stations and $1984-1985$ averages for rural stations.

We first examined the spatial pattern of the temperature trends for the individual stations and the results of the regional average are included in Figure 1. In general, the regions of the Northeast, and Northern Plains and Northwest showed large positive trends for both the urban and rural stations while negative urends were observed in the Southwest. Note that these results imply a tendency for a decrease in the north-south temperature gradient. The thirry-year trends averaged over the Eastern half of China were $0.36^{\circ} \mathrm{C}$ for the urban stations and $0.24{ }^{\circ} \mathrm{C}$ for the rural stations.

Figure 2 shows the 1954.1983 annual mean temperatures averaged over the 42 urban and rural stations separately. In general, three stages are observed for both the urban and rural temperatures: a warming trend before 1961; a cooling trend between 1961-1969; and a warming trend after 1969. The temperatures averaged over the thirty years for rural and urban stations are calculated to be $12.61^{\circ} \mathrm{C}$ and $12.80^{\circ} \mathrm{C}$, respectively.

These urban-rural temperature differences however, include factors such as differences in geography and lopography, which will have influences on the temperature differences. To minimize the effeci of topography and geography, we used multiple regression techniques. The differences in altitude, latitude and longitude between the paired urban and rural stations were used to predict the urban-rural remperature difference. The residuals between these

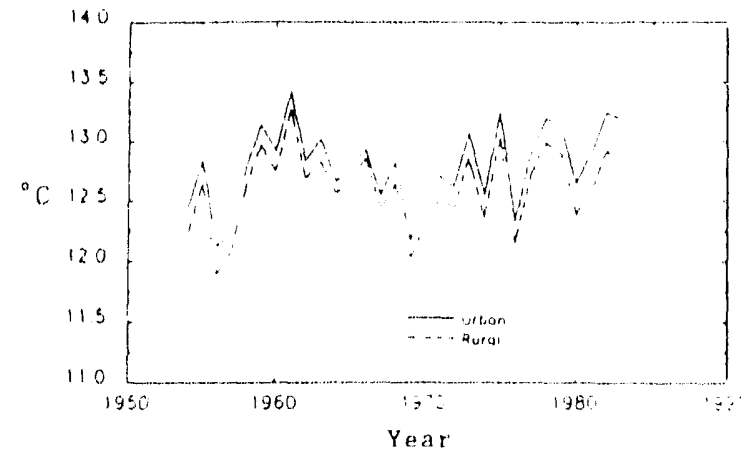

Fig. 2: The annual mean temperatures averaged over the urban and rural stations shown in Figure 1. The mean iemperatures for rural and urban stations averaged over $1954-1983$ are $12.61^{\circ} \mathrm{C}$ and $12.80^{\circ} \mathrm{C}$, respectively. predictions and the actual urban-rural temperature differences were used to refine the urban-rural differences. The differences are referred to as "corrected" differences. Using the F-test, we find that the regressions are statistically significant at the 0.01 significance level for the annual averages and at the 0.05 level for the seasonal averages.

The corrected annual and seasonal urban heat islands are given in Table 1. The results indicate that temperatures averaged $0.23{ }^{\circ} \mathrm{C}$ warmer in the urban areas across all regions and seasons (as opposed $100.19^{\circ} \mathrm{C}$ for the uncorrected urbanrural difference). Averaged across all of China, the strongest urban heat islands, $0.29^{\circ} \mathrm{C}$, occurred in winter and the weakest, $0.14^{\circ} \mathrm{C}$, in summer. Considerable variability exists from region to region however, and a portion of this variability is unlikely to be related to heat island effects. For example, if we omit the Northern Plains which has a very large difference between summer and winter, then the results are similar to those observed in the United States: stronger heat islands cccur in summer compared to winter (T'able 1). As such, the summer to winter differences may not be significant. liurther sludy of the characteristics in the region of Northern Plains, including the data quality, is warranted. The Middle-Lower Changijang and Huaihe Basin and the Northwest also showed a large annual urban heat islands (about $0.35^{\circ} \mathrm{C}$ ), but the seasonal variation is relatively small; in fact, these two regions logether with the Northern Plains dominate the annual average urban-rural temperature difference of $0.23^{\circ} \mathrm{C}$ for all of China. The urban-rural temperature differences in other areas were small. The large difference between regions suggests that more ditia would be desirable to detemine whether the regional differences are sampling errors or real physical characteristics.

The interannual variability of the annual and seasonal mean urban-rural temperatures is shown in Figure 3. This is of particular interest with respect to potential urban heat island biases in long-term temperature series derived from urban stations in China. For the annual-mean case (Figure 3 a) the changes in the urban-rural temperature difference had two stages, a decreasing trend before 1966 and an increasing trend afterwards. The magnitude of the increase is particularly large after 1977. These trends may be associated with energy consumption and population movement resulting from comentic and frolitical activitics duting the periods of the Great Leap Forward before 1966 and the Cultural Revolution afterward. During those periods, many factories were closed and production halted through a reduction of the staff. Since 1972, industry functions gradually returned to normal and after 
Table 1. Annual and seasonal urban heat islands $\left({ }^{\circ} \mathrm{C}\right)$ in China averaged over the period 1954.1983

\begin{tabular}{lccccc}
\hline Region & Spring & Summer & Autumn & Winter & Annual \\
\hline Northeast & 0.18 & 0.03 & -0.09 & 0.06 & 0.04 \\
Northern Plains & 0.20 & -0.18 & 1.07 & 1.42 & 0.63 \\
Middle-Lower & 0.44 & $0.4 ?$ & 0.38 & 0.21 & 0.36 \\
$\begin{array}{l}\text { Changlang and } \\
\text { Huaihe Basin }\end{array}$ & & & & & \\
Southeast Coast & -0.13 & 0.20 & 0.03 & -0.08 & 0.01 \\
Southwest & 0.24 & 0.04 & -0.05 & -0.22 & 0.00 \\
Northwest & 0.32 & 0.35 & 0.36 & 0.35 & 0.35 \\
China-Mean & 0.21 & 0.14 & 0.28 & 0.29 & 0.23 \\
& $(0.21)^{\dagger}$ & $(0.21)$ & $(0.13)$ & $(0.06)$ & $(0.15)$ \\
& & & & & \\
$\quad$ Standard & 0.19 & 0.22 & 0.44 & 0.59 & 0.26 \\
Deviation & $(0.21)$ & $(0.17)$ & $(0.22)$ & $(0.22)$ & $(0.18)$ \\
\hline
\end{tabular}

* The annual value is $0.28^{\circ} \mathrm{C}$ if the Hohhot-Urad Zhongqi pair in the far west is excluded (see Figure 1); this will have a small effect on the annual mean over China, reducing to 0.22

${ }^{\circ} \mathrm{C} . \dagger$ Values in the parentheses are the averages without including the Northern Plains.
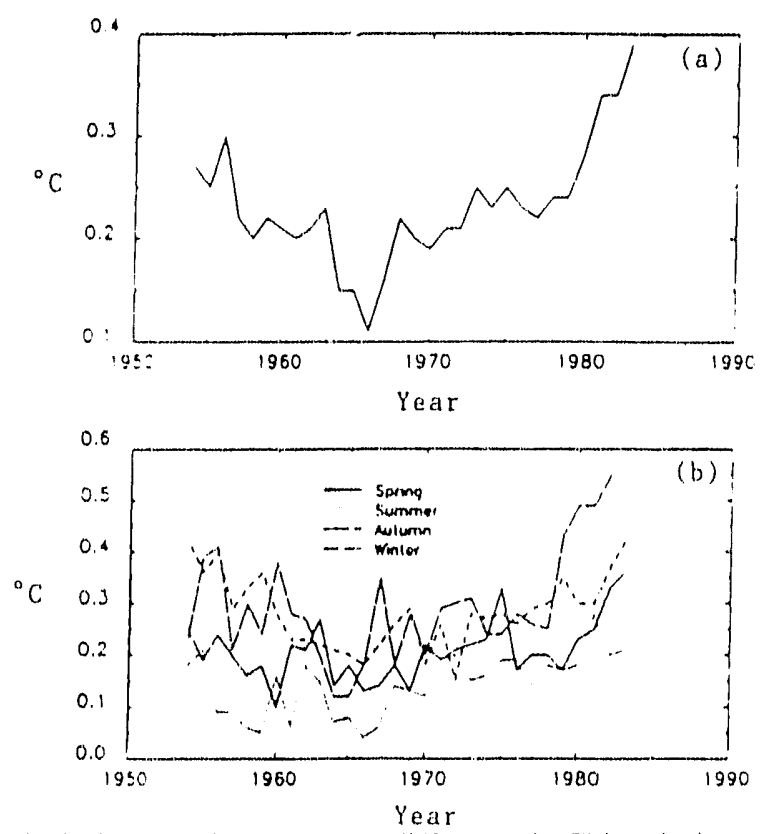

Fig. 3: Urban-rural temperature difference in China during 1954-1983 for (a) annual mean and (b) seasonal mean valuus.

1978, factory production and economic development rapidly expanded under the new Open Door policy. As a result, a large inflow of rural population to the cities oxcurred so that the urban heat islands in China may have increased as a result.
This is evident beginning the year $19 \% 7$ in Figure 3a. Much more detailed analyses of the attributes are needed however, before we can be certain of the causes for such trends.

On a seasonal basis (Figure 3b), similar features are also observed. It is quite clear that, for all four seasons, the magnitudes of the urban heat island bias after 1966 has been increasing. The trend is particularly strong during autumn and winter. Before 1966, except for autumn and winter, the urbanrural temperature differences showed little trend.

The annual and seasonal urban heat-island bias during the three ten-year periods are summarized in Table 2 . The values reflect the heat island features discussed above: maximum during winter and minimum during summer for the average of all regions, but just the opposite when the Northern Plains is omitted from the sample. Increased heat islands occur during the most recent decade for all of Eastern China with and without the Northern Plains. We have also examined the urban heat island bias for the three ten-year periods on the regional basis, shown in Table 3. The general characteristics are similar to the annual features observed in Table 2. However, the decadal changes in urban-rural temperature differences are large in Northeast, Northern Plains, Southeast Coast, and the Northwest while the other two regions showed small changes. Because of the lack of population statistics in China, in the analysis of the relation between population and heat island effects we used the available population dala during 1581-1985 for the cities and 1984-1985 for the rural stations. The population difference versus the temperature difference for the individual urban-rural pairs we e used to derive an empirical correlation. The relationship exists. However, the correlation is not statistically significant, which suggests that we would problably need many more station pairs before we could

Table 2. Annual and seasonal urban heat islands $\left({ }^{\circ} \mathrm{C}\right)$ in China

\begin{tabular}{cccccc} 
Period & Spring & Summer & Autumn & Winter & Annual \\
\hline $1954-6.3$ & 0.20 & 0.12 & 0.31 & 0.29 & 0.23 \\
& $(0.21)^{*}$ & $(0.19)$ & $(0.18)$ & $(0.06)$ & $(0.16)$ \\
1964.73 & $(0.17$ & 0.12 & 0.22 & 0.23 & 0.19 \\
& $(0.19)$ & $(0.18)$ & $(0.06)$ & $(0.0 !)$ & $(0.1 !)$ \\
$1974-83$ & 0.25 & $(0.19$ & $(0.31$ & 0.36 & 0.28 \\
& $(0.23)$ & $(0.25)$ & $(0.16)$ & $(0.13)$ & $(0.19)$ \\
& & & & &
\end{tabular}

* Values in the parentheses are the averages without including the Northem Plains. 
D.6

Table 3. Annual urban heat islands $\left({ }^{\circ} \mathrm{C}\right)$ in China

\begin{tabular}{lcccc}
\hline Region & $1954-63$ & $1964-73$ & $1974-83$ & $1954-83$ \\
\hline Northeast & 0.00 & -0.03 & 0.16 & 0.04 \\
Northem Plains & 0.62 & 0.57 & 0.70 & 0.63 \\
Middle-Lower & 0.41 & 0.34 & 0.34 & 0.36 \\
$\quad$ Changilang and & & & & \\
Huaihe Basin & 0.00 & -0.05 & 0.06 & 0.01 \\
Southeast Coast & 0.01 & 0.01 & -0.01 & 0.00 \\
Southwest & 0.35 & 0.28 & 0.42 & 0.35 \\
Northwest & 0.23 & 0.19 & 0.28 & 0.23 \\
China & & & & \\
\hline
\end{tabular}

predict the magnitude of the urban heat islands on an annual basis.

\section{Conclusions and Discussion}

We used the 1954-1983 surface temperature data in Eastern China to examine the urban heat island effects. The average effect wasi calculated to be quite substantial in our data, about $0.23{ }^{\circ} \mathrm{C}$ for the last thirty years. The heat island effects also had strong seasonal and regional dependences with considerable variability.

Our focus in the present study has been mainly on the urban-rural temperature difference so that the choice of the station network was strictly based on the station pairs and their homogeneous distribution. Consequently, our rural stations are generally not the true "rural" stations; rather they are cities with fairly large populations (see Figure 1). Our results suggest that in the absence of other factors which could cancel the urban heat island bias, stations in China located in the vicinity of major cities have relatively large heat islands. The char ges in the magnitude of the urban-rural temperature differences over the 1954-83 period indicate that since the late 1970 's the rate of warming at urban stations is over $0.1^{\circ} \mathrm{C}$ per decade relative to more rural stations. Although there has been rapid urbanization in China since the 1970's, it is not certain whether the trend from such a short period should be attributed solely to urbanization. An updated data set may clarify this situation. These results suggest that caution must be used when using trends from stations in the vicinity of major metropolitan areas.

Acknowledgments. Zhaomei Zeng participated in the study as a visiting scholar under the United States Department of Energy and the People's Republic of China's Academy of Sciences Joint Research on the Greenhouse Effect. This research was supported by the Atmospheric and Climate Division, Office of Health and Environmental Sciences, Department of Energy.

\section{References}

Balling, R. C., Jr. asd S. B. Idso, Historical temperature trends in the United States and the effect of urban population growth, L. Geophys. Res. .94, 3359-3363, 1989.

CE5, Our changing planet: the FY 1990 research plan, a report by the Committee on Earth Sciences, Washington D.C.. 1989
Chow, S. D., Some aspects of the urban climate of Shanghai, Proceedings of the Technical Conference: Urban Climatology and it: Applications with Special Regard to Tropical Areas, edited by T. R. Oke, World Meterorological Organization, No. 652, 87.109, 1986.

Domros, $\mathrm{M}$, and $\mathrm{G}$. Peng, The Climate of China, $360 \mathrm{pp}$., Springer-Verlag, Berlin-Heidelberg-New York L.ondonParis-Tokyo, 1988.

Jones, P. D., P. Ya Groisman, M. Coughlan, N. Plummer, W..C. Wang and T, R. Karl, How large is the urbanization bias in large-area-averaged surface air temperature trends? Nature, 347, 169-172, 1990.

Karl, T. R. and R. G. Quayle, Climatic change in fact and theory: Are we collecting the facts', Slimatic Change. 13, 5-17, 1988.

Karl, T. R., H. Diaz, and G. Kukla, Urbanization: Its detection in the U. S. climate record, LClim. L 1099-1123, 1988.

Koomanoff, F, T. Y'e, M. R. Riches, C. Zhao, W.-C. Wang, and S. Tao, U.S. Department of Energy and P. R. C. Chinese Academy of Sciences Joint Research on Greenhouse Effect, Bull Amer. Meteor. Soc. 61, 1301 $1308,1988$.

Wood, F. B., Comment: on the need for validation of the Jones et al. temperature trends with respect to urban warming, Slimatic Change.12, pp. 297-312, 1988.

Worlu Meteorological Organization/United Nations Environmental Programme, An intergovernmental panel on clinate change working group i repon, scientific assessment of climate change, 1990.

Zhou, S. Z. and C. Zhang, (Eds), Urban heat islands, Urban Climate Section 5, pp. 85-132 (in Chinese), 1985.

T. R. Karl, National Climatic Data Center/NOAA, Battery Park and Page Street, Asheville, NC 28801 W.-C. Wang, Atmospheric Sciences Research

Center/SUNY, 100) Fuller Road, Albany, NY 12205.

Zhaomei Zeng, Institute of Atmospheric Physics, Chinese Academy of Sciences, Beijing, Chine

\footnotetext{
(Recelved August 24, 1990; revised october 12, 1990; accepted October 15, 1990)
} 


\section{INTERNAL DISTRIBUTION}

1. T. A. Boden

2. J. H. Cushman

3. R. M. Cushman

4. M. P. Farrell

5. D. E. Fowler

6. C. W. Gehrs

7. S. G. Hildebrand

8. D. P. Kaiser

9. P. Kanciruk

10. D. E. Reichle

11. D. S. Shriner

12. S. H. Stow

13. R. I. Van Hook

14-113. CDIAC

114. Central Research Library

115-118. ESD Library

119. Information Analysis Library

120-121. Laboratory Records Department

122. Laboratory Records, RC

123. ORNL Patent Office

124. ORNL Y-12 Technical Library

\section{EXTERNAL DISTRIBUTION}

125. Rogei C. Dahlman, Carbon Dioxide Research Program, Environmental Sciences Division, Office of Health and Environmental Research, ER-74, U.S. Department of Energy, Washington, DC 20585

126. David Easterling, National Climatic Data Center, Federal Building, Asheville, NC 28801

127. Jerry F. Franklin, Bloedel Professor of Ecosystem Analysis, College of Forest Resources, University of Washington, Anderson Hall (AR-10), Seattle, WA 98195

128-132. Fu Congbin, Institute of Atmospheric Physics, Chinese Academy of Sciences, Beijing, China

133. David J. Galas, Office of Health and Environmental Research, ER-70, U.S. Department of Energy, Washington, DC 20585 
134. Themals J. Gross, Carbon Dioxide Rescarch Progham, Environmental Sciences Division. Offiee of Heallh and Environmental Research, ER.74, U.S. Department of Encrey, Washinglon, $D(20) 585$

135. Sultan Hameed, Laboratory for Planctary Amospheres Research, State Universily of New York, Stony Brooks, NY $11794.230(1)$

136. George M. Hornberger, Department of Environmental Sciences, Clark Hall, Universily ol' Virginia, Charletlesville, VA $229(1) 3$

137. Pamela Hughes, National Climatic Data Center, federal Building, Asheville, NC: $288(1) 1$

138. Roy L. Jenne, Nalional Center for Almospherie Research, P.O. Box 30(0), Boulder, CO) $8(0.31) 7.30(1)(1)$

139. (i. Y'. Jordy, Director, Office ol P'rogram Analysis, Office ol' Energy Research, ER-30, (i-226, U.S. Department of Energy, Washinglon, DC 20585

140. Thomas R, Kanl, Naltional Climalic Dana Center, Federal Building, Asheville, NC 288()$!$

141. F. A. Koomanoff, Office of Basic Energy Sciences, ER-10, U.S. Department of Encrgy, Washinglon, DC 201585

142. T. K. Lau, Program Offiece, Offïce of Internalional Alfairs, IE-12, U.S. Department of Energy, Forrestal Building, Washington, DC 20585

143. H. M. MeCammon, Acting Deputy Director, Environmental Sciences Division, Olliece of Health and Environmental Rescarch, Olfice of Energy Rescarch, ER-74, U.S. Department of Energy, Washington, DC. 20.585

144. R. H. Olsen, Vice President for Research, University of Michigan, Medical Science Building II, \#56(15, 1301) East Contherine Street, Ann Arbor, MI 48109-(0620)

145. Ari Pallinos, Acting Director, Banvirommental Sciences Division, Offiec of Health and Environmental Resciarch, ER.74, U.S. Department of Energy, Washinglon, DC 20.585

146. David Portman, Amospheric and Environmental Research, Incorporated, 840) Memorial Drive, Combridge, MA 02139

147. Michace R. Riches, Carbon Dioxide Research Program, Enviromental Sciences Division, Oflice of Healdh and Environmental Research, ER-7A, U.S. Department of Encergy, Wolshinglon, DC 211585

1.48. Peler M. Steurer, Nattomal Climatic Datal Center, Federal Building, Asheville, NC: $2 \operatorname{sis}(1) 1$ 
149-153. Tho Shiyan, Institute of Atmospheric Physics, Chinesc Academy of Sciences, Beljing, China

154-156. Wei-Chyung Wang, Prolessor and Head, Climate System Sciences, Atmospheric Sciences Research Center, University of Albany, State University of New Y'ork, 100 Fuller Road, Albany, NY 12205

157. F. J. Wobber, Environmental Sciences Division, Orlice of Health and Environmental Rescarch, Oflice of Energy Rescarch, ER-74, U.S. Department of Energy, Washington, DC 20585

158-162. Zeng Zhaomei, Institute of Atmospheric Physics, Chinese Acad.my of Scienees, Beijing, China

163-167. Zhang Qingyun, Institute of Atmospheric Physics, Chinese Acidemy of Sciences, Beijing, China

168. Office of Assistant Manager for Energy Research and Development, Oak Ridge Operations, P. O. Box 2001, U.S. Department of Energy, Oak Ridge, TN 378.31-8600)

169-178. Olfice of Scientific and Technical Information, P. O. Box 62, Oak Ridge, TN 378.31 

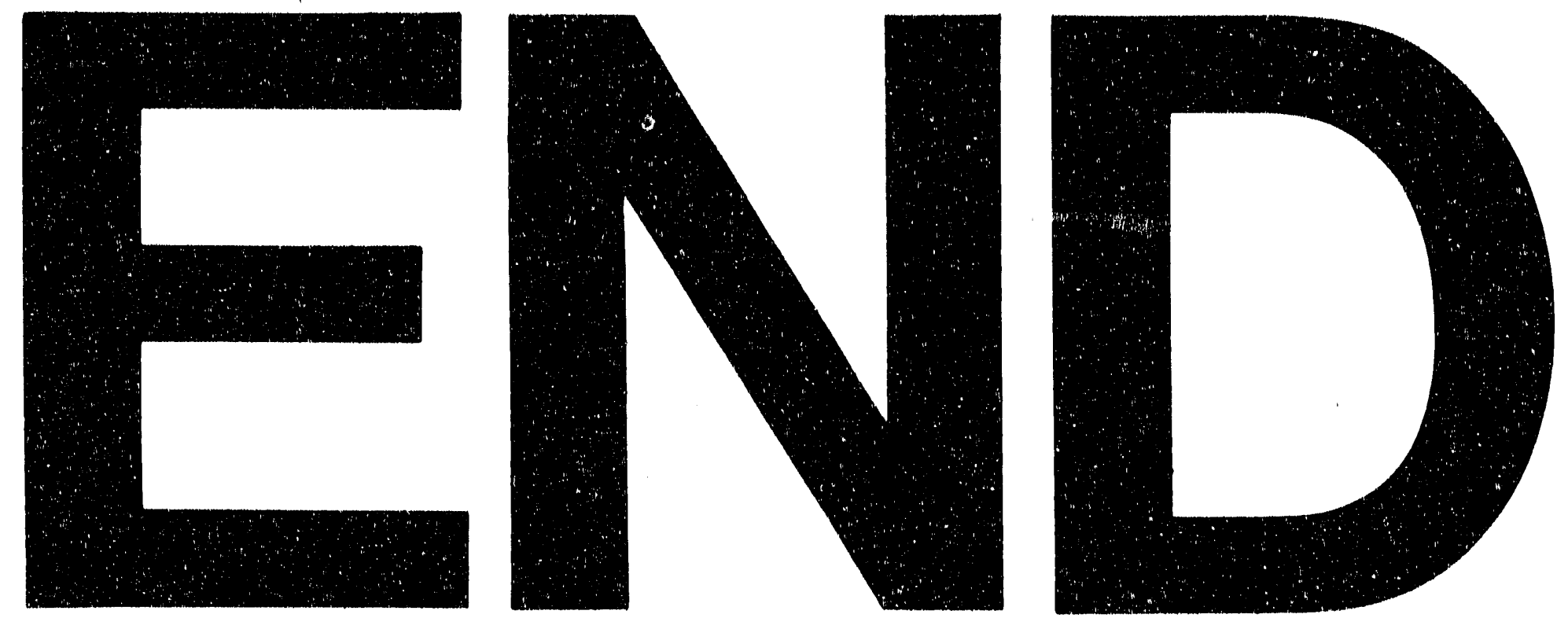

乎

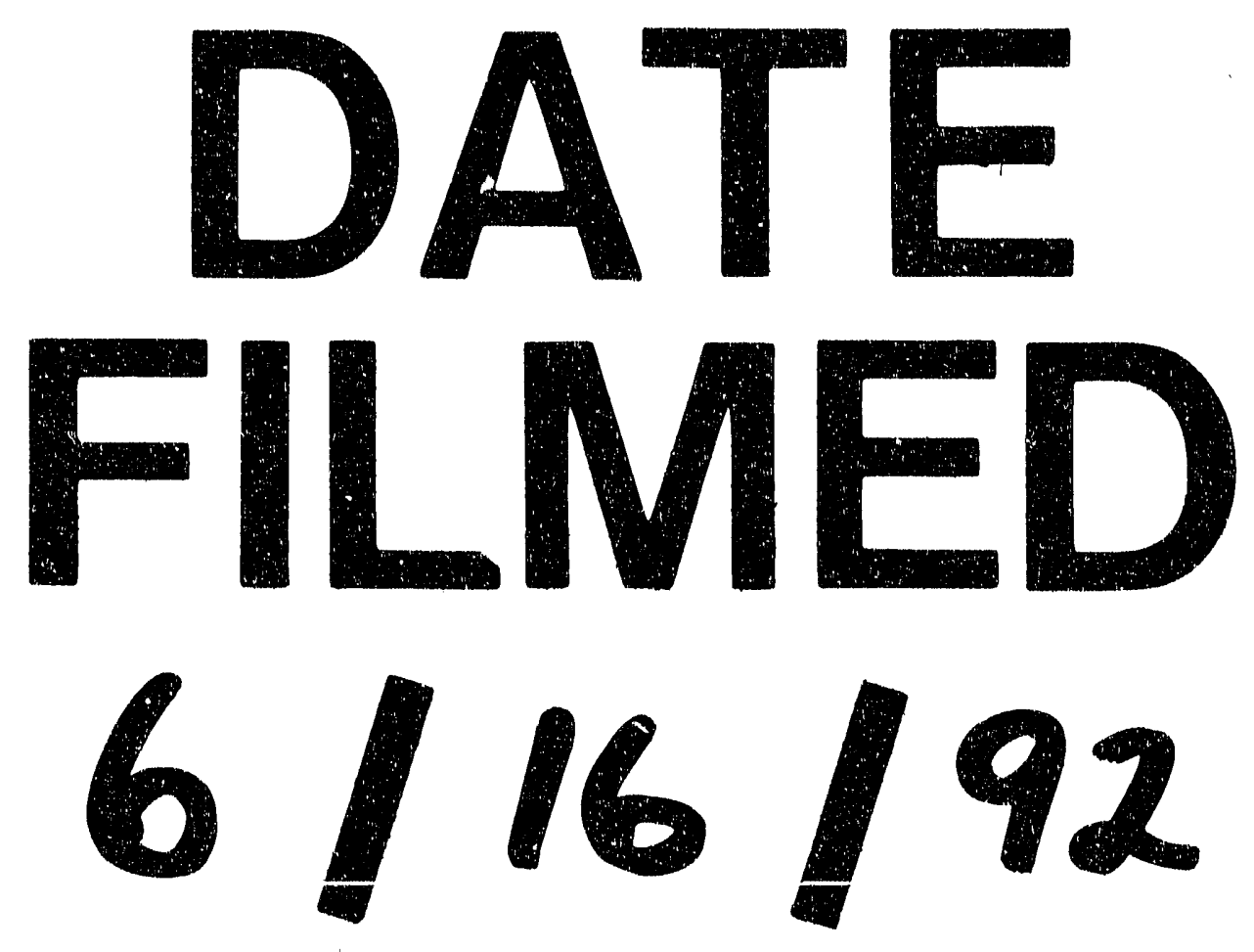

壕 
